\title{
Immigration and
}

Social Systems

Collected Essays of Michael Bommes

CHRISTINA BOSWELL \& GIANNI D’AMATO (EDS.)

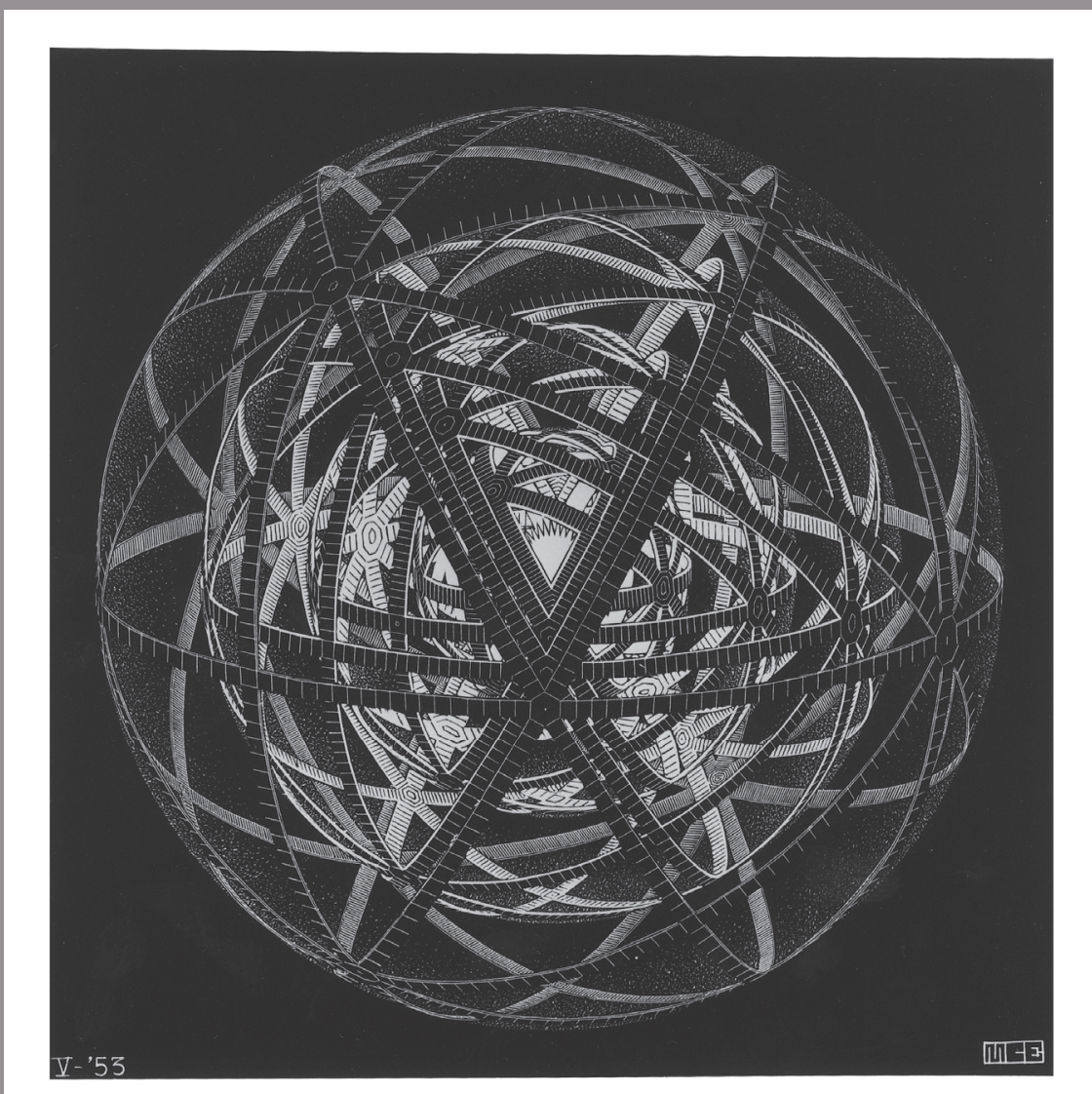


Immigration and Social Systems 


\section{IMISCOE}

\section{International Migration, Integration and Social Cohesion in Europe}

The IMISCOE Research Network unites researchers from, at present, 28 institutes specialising in studies of international migration, integration and social cohesion in Europe. What began in 2004 as a Network of Excellence sponsored by the Sixth Framework Programme of the European Commission has become, as of April 2009, an independent self-funding endeavour. From the start, IMISCOE has promoted integrated, multidisciplinary and globally comparative research led by scholars from various branches of the economic and social sciences, the humanities and law. The Network furthers existing studies and pioneers new scholarship on migration and migrant integration. Encouraging innovative lines of inquiry key to European policymaking and governance is also a priority.

The IMISCOE-Amsterdam University Press Series makes the Network's findings and results available to researchers, policymakers and practitioners, the media and other interested stakeholders. High-quality manuscripts authored by Network members and cooperating partners are evaluated by external peer reviews and the IMISCOE Editorial Committee. The Committee comprises the following members:

Tiziana Caponio, Department of Political Studies, University of Turin / Forum for International and European Research on Immigration (FIERI), Turin, Italy

Michael Collyer, Sussex Centre for Migration Research (SCMR), University of Sussex, United Kingdom

Rosita Fibbi, Swiss Forum for Migration and Population Studies (SFM), University of Neuchâtel / Institute of Social Sciences, University of Lausanne, Switzerland

Agata Górny, Centre of Migration Research (CMR) / Faculty of Economic Sciences, University of Warsaw, Poland

Albert Kraler, International Centre for Migration Policy Development (ICMPD), Vienna, Austria

Jorge Malheiros, Centre of Geographical Studies (CEG), University of Lisbon, Portugal

Marco Martiniello, National Fund for Scientific Research (FNRS), Brussels / Center for Ethnic and Migration Studies (CEDEM), University of Liège, Belgium

Marlou Schrover, Institute for History, Leiden University, The Netherlands

Patrick Simon, National Demographic Institute (INED), Paris, France

Miri Song, School of Social Policy and Sociology, University of Kent, United Kingdom

IMISCOE Policy Briefs and more information on the network can be found at www. imiscoe.org. 


\section{Immigration and Social Systems}

Collected Essays of Michael Bommes

edited by Christina Boswell and Gianni D'Amato

IMISCOE Research

AMSTERDAM UNIVERSITY PRESS 
Cover illustration: M.C. Escher's Concentric Rinds (C) 2012 The M.C. Escher Company B.V., Baarn, The Netherlands. All rights reserved. www.mcescher.com

Cover design: Studio Jan de Boer BNO, Amsterdam Layout: The DocWorkers, Almere

ISBN 9789089644534

e-ISBN 9789048517299 (pdf)

e-ISBN 9789048517305 (ePub)

NUR $741 / 763$

(C) Christina Boswell and Gianni D'Amato / Amsterdam University Press, Amsterdam 2012

All rights reserved. Without limiting the rights under copyright reserved above, no part of this book may be reproduced, stored in or introduced into a retrieval system, or transmitted, in any form or by any means (electronic, mechanical, photocopying, recording or otherwise) without the written permission of both the copyright owner and the author of the book. 


\section{Table of contents}

Foreword

Rinus Penninx

Preface

Christina Boswell and Gianni D'Amato

Introduction

Christina Boswell and Gianni D'Amato

1 Migration in modern society

2 National welfare state, biography and migration:

Labour migrants, ethnic Germans and the re-ascription of welfare state membership

3 Systems theory and the 'ethnic inequality' of migrant workers

4 Welfare systems and migrant minorities:

The cultural dimension of social policies and its discriminatory potential

$5 \quad$ Transnationalism or assimilation?

6 'Integration takes place locally':

On the restructuring of local integration policy

$7 \quad$ Illegal migration in modern society:

Consequences and problems of national European migration policies

8 General and specific characteristics of networks (with Veronika Tacke)

9 National paradigms of migration research (with Dietrich Thränhardt) 



\section{Foreword}

IMISCOE owes a lot to Michael Bommes. It is no surprise that he was a key figure in the groundwork and establishment of the IMISCOE Network of Excellence. Michael took on several important roles in our organisation. He led the research cluster on economic integration. As director of the Institute for Migration Research and Intercultural Studies (IMIS), he hosted the Second Annual IMISCOE conference at the University of Osnabrück. To this day, Michael remains irreplaceable on the IMISCOE Board of Directors, where his modestly offered interventions and proposals were as constructive as they were brilliant. When the Network of Excellence transformed itself into the current IMISCOE Research Network, his support and advice were always to be found.

Although he passed away on 26 December 2010, Michael knew that IMISCOE hoped to bring together the fruit of his labour, publishing it as a whole. Even during his protracted period of illness, he continued to work as much as possible. Among other things, he sharpened and updated some of his earlier articles, which now form part of this manuscript.

This publication of his major contributions to the field of migration and integration studies is a way of honouring Michael, our colleague. At the same time, it is meant to serve the scientific community by making the nationally acclaimed research of Professor Bommes available and accessible to a wider, international readership. It was easy to carry on the momentum of such a scholar, motivated and engaged till his last breath.

Rinus Penninx

Coordinator IMISCOE Research Network 



\title{
Preface
}

\author{
Christina Boswell and Gianni D’Amato
}

Michael Bommes was an outstanding scholar and an enormously influential figure in the field of migration studies. With a characteristically German background in sociology - being heavily influenced by the theory of Niklas Luhmann - he was able to translate and export complex ideas across his extensive network of research collaborators and students throughout Europe, Turkey and North America. Michael himself had a strong impact on German sociology, contributing to important theoretical innovations and the opening up of new areas of research. He was also pivotal in initiating collaboration among researchers and policymakers both within Germany and at the European level. His scholarly interest had an unusually broad sweep, from linguistics and philosophy to economics and organisation theory.

In mid-2010, Michael was faced with the prospect that he may be unable to fight his illness. At the suggestion of the editors, he began to develop the idea of publishing a book that would disseminate his contributions on immigration and integration to a larger, English-reading audience. As colleagues enjoying a long-standing friendship with Michael, who have gained much from his wise advice and unflagging support, we were honoured to carry through this project. Michael put a lot of energy into the selection and presentation of the articles in this, his last book. He saw the final manuscript before he died on 26 December 2010.

In Michael, we lost a friend with a great sense of loyalty and humour, but also a passionate interlocutor with broad knowledge in many fields, from Schubert to the Bundesliga. We miss his sonorous voice, his sharp wit and ironic insights and not least his enjoying a well-earned pint after an intense research discussion or seminar.

Our acknowledgements go to all those who were close to Michael and who helped make this book possible. We thank Sigrid Pusch, who managed his office and helped us in numerous ways to prepare the manuscript at the project's onset. We are particularly indebted to Andrea Lenschow, Michael's companion in life, and to Andreas Pott, his successor at the University of Osnabrück. Both offered crucial comments and precious advice during the production of this edition. A special thanks goes to Karina Hof, managing editor of the IMISCOE Editorial Committee, and to Rinus 
Penninx, coordinator of the IMISCOE Research Network, both of whom have been extremely supportive and helpful throughout preparation of this publication. 


\title{
Introduction
}

\author{
Christina Boswell and Gianni D'Amato
}

Michael Bommes was one of the most innovative and profound theorists of immigration and integration of our time. His work drew on the systems theory of Niklas Luhmann to develop a highly compelling and sophisticated alternative to predominant contributions in migration studies. His writing constantly questions and challenges mainstream theories and concepts in migration studies, from notions of assimilation and transnationalism, to multiculturalism and discrimination, irregular migration and migrant networks. But equally important is his attempt to advance sociological research through the lens of immigration. His repeated assertion is that immigration has had major consequences for modern social systems and welfare states, and that understanding these impacts needs to be a central question not just for migration scholars, but for sociologists more generally.

Through his research, teaching and policy work, Bommes earned himself a dedicated following, especially across Europe. However, we feel that his work deserves an even wider audience. One of the impediments to achieving a broader impact is that much of his work has been published exclusively in German or in outlets that are not widely disseminated outside of German-speaking countries. Michael's tragic and untimely death in 2010 also meant that he never had the opportunity to collect the different strands of his opus into one collection.

This book therefore brings together what we believe is a representative sample of Bommes' most important work on migration and integration. It includes a number of articles or chapters that are appearing in English for the first time, as well as articles that were published in German outlets. The book starts with a series of four chapters on immigration, social systems and the modern welfare state, one of the core themes of his work. Two chapters follow on immigrant integration, with subsequent chapters dealing with, respectively, illegal migration, networks and migration research. In this brief introduction, we start by setting out some of the key themes of his work and introduce the nine chapters. In a second part, we say something about Bommes' academic career and his work with students and practitioners. 
Bommes was particularly gifted in bridging applied themes in migration research with broader theoretical questions in sociology. Many of his essays start with a question, which is currently modish in migration research: How does immigration affect welfare states? Are western welfare states culturally discriminatory? Which is more plausible, transnationalism or assimilation? In what sense does integration take place at the local level? He then proceeds to unravel the question in his characteristically rigorous and methodical style, gradually building up a line of argument that poses a powerful challenge to received wisdom on the topic.

Bommes' distinctive account is informed by Luhmann's theory of social systems. According to this theory, the primary building blocks of modern society are not individuals or groups, but functionally differentiated social systems. In pre-modern, stratified societies, rank and status provided the primary categories of the societal fabric, determining social roles and life opportunities. But modern societies have become increasingly divided into autonomous systems such as education, health, economy, religion, welfare or housing. Each of these operates according to its own distinct codes, programmes, logic and mode of inclusion, which regulates which individuals are relevant participants. Indeed, societal subsystems tend to operate according to fundamentally inclusive criteria, not linked to ethnicity or national origin, thematising the individuals' actions and communications exclusively in terms of each system's generalised code and programmes. Thus, the labour market as a product of a modern economy operates according to a logic that selects workers according to their skills and price (ethnicity or nationality being relevant only insofar as they may be converted in variations of skills and prices); and public health, education and welfare institutions generally adopt criteria of inclusion based on the life stage or needs of individuals.

This theory of functional differentiation has two quite radical implications for migration studies. First, it implies that international mobility is a quite normal and expected response to the inclusive character of social systems. The labour market, housing, education and health systems are, in principle, quite accessible for foreign residents in terms of their functional codes - even for those without regular status - and are actually willing to include them based on their ability to conform to systems-specific criteria of inclusion. Although the political systems of welfare states may attempt to exclude non-citizens or non-residents (more on this below), the systems most important to an individual's well-being tend to be blind to their national or ethnic origin. This provides a fresh and unorthodox perspective for making sense of mobility, irregular migration and integration processes.

Second, systems theory implies that in order to understand immigration and integration, we need to study immigrants' inclusion within, and impact 
on, these differentiated systems. Concepts such as 'integration into society', 'social cohesion' or 'community relations' are unhelpful, as the researcher has no possible way of observing or making sense of 'society' as an integrated whole, or the characteristics of 'ethnic groups' as such. Instead, the characteristics and behaviour of individuals only make sense from the perspective of their participation in a number of distinct social systems, whether these be functional systems in general, or organisations in particular. Again, this perspective has far-reaching consequences for research on immigration integration.

Bommes' social theory is augmented by the importance he pays to a second type of social system crucial to modern society: organisations. While he argues that social systems are essentially inclusive, one of his most important contributions to systems theory is his work on the role of organisations in perpetuating forms of discrimination and inequality. Recognising that, in practice, immigrants frequently face impediments to participation and equality of life chances, Bommes sought to explain such disadvantages in terms of organisations. Access to welfare, education or employment, for example, is implemented via organisations that specify terms of membership, access to services or recruitment. They tend to base decisions on standardised expectations about 'normal' or appropriate life courses. Those who deviate from such standardised careers - and this often includes immigrants - may suffer from particular barriers to inclusion. So it is the institutionalisation of expected careers or life courses that leads to indirect discrimination against migrants in welfare states.

These concepts of social systems and organisations are elaborated and applied to make sense of a variety of issues in migration research. Chapter 1 of the book, 'Migration in modern society', explores the relationship between functional systems and the welfare state. While most social systems, as we have seen, operate according to inclusive criteria of participation, immigrants are clearly seen as a problem in political terms. Indeed, unlike other social systems, modern welfare states as organisational systems operate according to a fundamentally exclusionary mode, i.e. national citizenship. Their logic of inclusion is exclusive and permanent, designed to guarantee a relationship of loyalty and service between citizens and state. Thus, despite the inclusionary tendencies of the functional systems most relevant to migrants' life chances, welfare states attempt to exclude access to noncitizens based on concerns about loyalty.

Chapter 2, 'National welfare state, biography and migration', develops this theme, discussing some of the means through which welfare states exclude non-citizens. Bommes suggests that welfare states mediate inclusion through developing and institutionalising predictable life courses, or biographies. Such biographies comprise sequences of inclusion into different systems, based on three main stages of life: childhood and education, founding a family and working life, and retirement. To participate in 
welfare provisions at each stage, the individual needs not just to meet the general conditions linked to that stage of life, but must also have accumulated relevant qualifications through participating in each stage. This is where migrants face problems, as they often deviate from these institutionalised life courses, for example, through limited or unrecognised educational qualifications, limited or unregistered labour or participation in pension schemes.

Chapter 3, 'Systems theory and the "ethnic inequality" of migrant workers', advances a complex argument about how systems theory can contribute towards theories of inequality. At first sight, systems theory would appear to be a poor candidate for explaining or addressing inequality: individuals' possibilities for inclusion (and thus their wealth or opportunities) are effectively fragmented across different social systems, each of which has its own mode of inclusion and no possibility for cross-system regulation of inclusion between systems. However, Bommes argues that it is the various organisations mediating inclusion into systems that imply the transferability of inequality across systems, and which reproduce inequality across generations. First, the organisations of the welfare state establish expectations about standard life courses or careers, which it is difficult for migrants (especially first-generation) to conform to. Thus, initial exclusion from education, labour or welfare implies further exclusions in other systems. Moreover, the initial exclusion of the first generation becomes reproduced for subsequent generations, as the organisations that mediate inclusion - through recruitment or extension of services - frequently base recruitment decisions on social networks, as well as fixed presuppositions about the characteristics of immigrant groups. Thus, while social systems are, in principle, inclusive, the organisations mediating access to them tend to transfer and reproduce inequality for certain groups.

Chapter 4, 'Welfare systems and migrant minorities', looks at the more applied question of whether European welfare states are imbued with cultural models which discriminate against ethnic minority groups. Bommes' seemingly counter-intuitive answer is that they are not: while welfare states may be highly exclusionary in their treatment of non-residents, they have proved to be generally inclusive of residents regardless of ethnicity. Indeed, welfare states are increasingly abandoning their preoccupation with national loyalty, instead focusing on 'activating' reforms to equip all members to be productive and competitive in the face of economic globalisation. However, some welfare states may indirectly discriminate against ethnic minorities insofar as their life courses deviate from institutionalised expectations (see chapters 2 and 3). Moreover, in cases where welfare states organise the delivery of services through cultural organisations (such as church groups in Germany or the Dutch system of pillarisation), one can indeed observe cultural discrimination based on religion. 
The next chapters turn to aspects of immigrant integration. Chapter 5, 'Transnationalism or assimilation?', offers a brilliant critique of current debates on integration. Bommes argues that the debate between transnationalists and assimilationists rests on a false opposition. On the one hand, transnationalists fail to understand that immigrants do assimilate when they take up roles inside organisations and fulfil the expectations linked to them indeed, assimilation is a 'basic condition of the mode of individual life in modern society'. However, assimilationists, in turn, make the mistake of assuming a strict coupling between assimilation across different dimensions - cognitive, structural, social and identificational. As transnationalists have observed, globalisation has led to a loosening of these couplings, so that assimilation across these dimensions does not necessarily take place in the same place. Thus, the debate between the two schools can be reformulated about two rival empirical hypotheses about strict or loose coupling of dimensions of assimilation.

Chapter 6 explores the claim that, as its title specifies, 'Integration takes place locally', which has become a familiar mantra of German and other European local authorities. Why has integration become such a priority and rallying cry for local government? Bommes rejects the claim that this is a response to a new crisis, or new research findings. Instead, it reflects the realisation that the welfare state has failed to effectively mediate the inclusion of growing numbers of migrants into social systems. The national political response has been to repackage existing measures in order to mobilise support and demonstrate that something is being done. Local authorities, meanwhile, are keen to be associated with this symbolic initiative because it enables them to procure additional resources and to legitimise their role. Nonetheless, such measures remain essentially symbolic, especially in the case of local authorities, which have limited means of steering those dimensions that might actually make a difference to inclusion, such as employment, education or family policy. Such levers continue to reside at the level of the national welfare state, or within functionally differentiated social systems.

In chapter 7, Bommes addresses the question of 'Illegal migration in modern society'. This is one of the central themes of his later work linked to the idea of the development of foggy social structures (as elaborated in his co-edited book Foggy social structures, published posthumously in the IMISCOE-Amsterdam University Press Series in $2011^{1}$ ). Building on earlier work on social systems and the welfare state, he argues that the inclusiveness of social systems generates multiple incentives and opportunities for irregular migrants to move in order to improve their life chances. Indeed, their status as illegal in many cases enhances their possibilities for inclusion because of their flexibility and limited demands. Political attempts to manage illegal migration, however, are fraught with contradictions. While the state is keen to retain its control over the population 
through enforcing the law, it is also committed to providing legal, political and social security for residents. Calls for regularisation may address the problem of immigrants' protection, but they imply that the state explicitly accepts law-breaking behaviour, renouncing control over its territory. Thus, many states resort to some form of limited recognition of the rights of irregular migrants, such as Duldung in Germany, which guarantees legal protection without implying an approval of the person's residence status.

Chapter 8, 'General and specific characteristics of networks', makes an outstanding contribution to theories of social networks, with important ramifications for the analysis of migrant networks. Bommes and co-author Veronika Tacke theorise networks as lists of addresses that enable participants to access heterogeneous and otherwise unconnected services through mobilising the resources of other participants. Networks are 'anchorless' in that both their membership and the expected reciprocity associated with membership are contingent on the motives for establishing them: they are not embedded in particular social or cultural roles or statuses. Nonetheless, some networks simplify their self-descriptions through adopting myths about the conditions and content of membership, such as ethnicity or kinship. Such descriptions miss the point about modern networks, i.e. the fact that they derive their rationale and scope from expectations about the reciprocal provision of services, rather than relationships of close proximity or shared characteristics. In so doing, they risk overburdening participants through setting up unfeasible expectations about both the scope of membership and the duties of reciprocity between members.

The final chapter, 'National paradigms of migration research', is one of Bommes' last papers. Co-authored with Dietrich Thränhardt, the piece returns to an earlier theme about the contribution of migration studies to core disciplines. The authors argue that migration research generally focuses on research problems and questions that are politically constructed, rather than worked up within their relevant disciplines. These politically constructed problems are associated with the particular challenges that immigration poses to national welfare states, and are influenced by nationally specific ways of framing these problems. Thus, despite some parallel tendencies in problematising and framing migration issues across states, migration research is nonetheless imbued with national paradigms. It is the politically applied nature of migration research that both guarantees its influence and funding base, but also explains its difficulty in making substantial contributions to its cognate disciplines of sociology, political science, geography, linguistics and so on.

We hope that these essays will challenge, provoke and, as they say in German, irritieren ('irritate') readers. Whether or not one accepts systems theory - and it certainly has strong critics within social science - it is a rich and compelling theory of society, which deserves serious attention. 
And, as these essays show, it offers an extremely fruitful base from which to challenge and critique otherwise accepted assumptions in migration research.

\section{II}

Bommes studied sociology, philosophy and linguistics at the University of Marburg, the University of Birmingham and the University of Osnabrück. He continued his academic career specialising in linguistics and migration, the topic of his $1990 \mathrm{PhD}$ thesis defended at Osnabrück. His focus subsequently shifted to questions of migration and the national welfare state, which was the subject of his 1999 habilitation (German professorial qualification). He then had a stint as a professor at the Pädagogische Hochschule Freiburg, before taking up the post at the University of Osnabrück in 2003.

Bommes' career was strongly bound up with the Institute for Migration Research and Intercultural Studies (IMIS) at the University of Osnabrück. As a member of IMIS from 1992 onwards, he served as a research assistant in the university's sociology department. In 2003, he became Professor of Sociology and Interdisciplinary Migration Research at the University of Osnabrück, a chair installed with the support of the Volkswagen Stiftung. From 2005 to 2009, he took over the directorship of IMIS and established what was for Germany a unique interdisciplinary master's programme in migration studies. Bommes became Dean of Social Science at the University of Osnabrück in 2006. He stepped down from this position and as director of IMIS when he fell ill in 2009, although this may have been the plan anyway as he had been invited to be a visiting professor in Toronto.

Bommes held an important place in German sociology, including chairing the migration and ethnic minorities section of the German Sociological Association. He was president of the German Migration Council, a group of experts set up to critically follow and advise immigration and integration policies, and he became a member of the Council of Experts of German Foundations on Integration and Migration (SVR). He was a member of the Migration Research Group at the Hamburg Institute of International Economics and a member of the board of directors of the European Commission-funded IMISCOE Network of Excellence, for which he led a research cluster on labour markets. He was also actively engaged in a number of international collaborations. In 1997 and 1998 he was Jean Monnet Fellow at the European University Institute in Florence, a research sabbatical that spawned important collaborations with a number of scholars in the United Kingdom, France, Italy and the United States. As a visiting professor in the sociology department at the University of Trento in 2008, he 
helped create their migration study centre, the Scenari Migratori e Mutamento Sociale (SMMS). He participated in several international collaborative research projects, including Political Economy of Migration in an Integrating Europe (PEMINT) from 2002 to 2004; The Integration of the European Second Generation (TIES) from 2006 to 2010; and, more recently, Fundamental Rights Situation of Irregular Immigrants in the European Union (FRIM) from 2009 to 2011.

Alongside his academic and teaching work, Bommes also made a significant contribution to migration policy. Although his work was highly theoretical, he had a great gift of communicating it in a way that made sense to policymakers and practitioners. This was certainly the case with reports he prepared for the German Migration Council, which made an important contribution to policy thinking on integration: indeed, the council's 2006 and 2008 reports are heavily imbued with concepts of social systems. Towards the end of his life, he was involved in advising the Council of Europe on issues of welfare states and immigrant integration, the inspiration for his paper on whether welfare states are culturally discriminatory (chapter 4 in this book).

Bommes was an inspiring - if demanding - teacher to his many students. He had an impressive ability to quickly grasp and engage with almost any research topic, across a variety of disciplines. He was always keen to apply his sharp theoretical mind to help develop a student's or colleague's research ideas. Part of his gift was his unique style of expounding an argument in seminars or conferences. He had a particular talent of being able to develop a complex line of argument or theoretical idea in front of his audience, giving listeners the impression that they were witnessing or even contributing to the development of his thought. His passionate interest in all aspects of immigration processes and research was infectious. It made him an invaluable - and sadly missed - participant in academic debate on migration research.

\section{Note}

I A full-length PDF of this book can be downloaded from the OAPEN library; for a direct link go to http://www.oapen.org/search?identifier=40I76r. 


\section{Migration in modern society}

First published in 2003 as 'Migration in der modernen Gesellschaft' in Geographische Revue 5 (2: pages 41-58)

Reprinted in 2011 in 'Migration und Migrationsforschung in der modernen Gesellschaft' in IMIS-Beiträge 38 (pages 49-68)

Translation into English for this book by Anja Löbert

I

One of the key claims of mainstream migration research is that it is dealing with significant social structural change which represents an empirical and theoretical challenge for the social sciences. Clearly, migration research focuses its attention on problems of social integration and inequality and on the resulting potential for conflict. It sees such problems as arising from the cultural and social resources of migrants, from their opportunities to participate, especially in labour markets, education systems, political and legal systems of the welfare state, health and care facilities, and also from urban housing conditions and the circumstances and living conditions which these entail for migrants.

It can be noted, however, that the success which migration research has achieved, in politics and also in science policy, is at the same time unable to produce any real scholarly resonance. While warnings about potential social conflict and disintegration do attract attention in the political sphere, and are certainly able to mobilise resources for research, sub-disciplinary and interdisciplinary research ${ }^{1}$ in the field of international migration receives little attention either on an intradisciplinary or interdisciplinary level, since its contribution to the general theoretical issues of the respective reference disciplines seems limited.

There is probably a simple reason for this: migration research tends to greatly restrict the frame of reference for its inquiry. It focuses less on the socio-structural prerequisites and consequences of international migration on the various levels of modern society, and more on migrants and their living conditions in those social contexts which are seen as significant, and 
how these conditions result from the context of integration and the structures of social inequality. The basis for this is a limited concept of the social structure which essentially includes the social relations of distribution and inequality. This limitation will not really become a problem for migration research, however, as long as the implicit normative preference for equality and social integration strikes a chord with its dual audience political and academic - to which migration research addresses its findings. The double articulation of the terminology as scientific concepts, on the one hand, and as more or less undeniable values on the other ${ }^{2}$ reinforces these conceptual foundations and lends them intuitive plausibility.

This focus of migration research can quickly be illustrated by means of a small number of examples.

1 While the migrant workers of the 1960s and 1970s (the so-called Gastarbeiter or guest workers) were initially studied in terms of the structural consequences for the labour market and for the use of infrastructural facilities in towns and communities (e.g. Körner 1976, summarised by Herbert 2000: 191ff.), functionally orientated towards, in particular, costbenefit considerations, subsequent migration research in the social sciences focused its analyses on how successful the social integration of the migrants was, as established through criteria such as occupational position, stability of employment conditions, income, social contacts and the like, and the more or less problematic living conditions arising from these factors. True, Marxist analyses work on a model in which they identify the structure of the relations of production as a causal context for international migration, but fundamentally their analysis targets the resulting relations of class and exploitation and the related problematic living conditions of migrant workers as an internationalised reserve army (Castles \& Kosack 1973; Castles 1987; Sassen 1988). More nuanced analyses thematise the particular role of the bourgeois state in a basically unchanging overall strategy (Dohse 1981). Despite differently applied analytical models, the studies of Hoffmann-Nowotny (1973) and Esser $(1979,1980)$, which have their roots in mainstream sociology, also focus on the social relations of inequality resulting from migration - socio-structural change through migration is then registered in the form of the neo-feudalisation of relations of stratification. Essentially what is at issue here are the effects of the more or less successful integration of migrants on their living conditions and on the social relations of inequality.

2 With regard to the second generation, numerous analyses focus their attention on the education system. The main concern here is the cultural prerequisites of the migrants or their children (Schrader, Nikles \& Griese 1976) for participation in the education system and their educational success, measured by the types of school attended, the school-leaving qualifications gained and the numbers entering training. The education system is expected to foster socio-structural change, mainly from a normative 
perspective, in the direction of models of intercultural education; the criterion here is the desired equality of migrant children (see e.g. Auernheimer 2003).

3 For about the last twenty years, internationally orientated research on the position of migrants in the political system has been comparing the politico-legal positions of various categories of migrant in civic, political and social respects, and their position in the various welfare-state security systems (Hammar 1985; Miles \& Thränhardt 1994; Faist 1995; Bommes \& Halfmann 1998; Bommes \& Geddes 2000). These are based on models in which equality for migrants is the desired outcome. Comparable results could be shown for the areas of housing, health and sport.

4 This perspective in migration research has not been disrupted by more recent approaches in so-called transnationalism, since these approaches see the main deficiency of migration research as being the limited nation state frame of reference for the analysis of processes of integration and assimilation. Transnationalism argues that these processes are now differently structured and play out in the frame of reference of so-called transnational social spaces. One does find studies here which thematise the consequences of international or transnational migrations and related social structural developments, taking the political system or the emergence of new industries and labour markets as examples (e.g. Hunger 2000; Levitt 2001). Here too, however, attention is focused on whether the conditions for integration and assimilation have changed with transnational migrations. Furthermore, the largely opaque phrase 'transnational social spaces' - from a theoretical point of view - merely indicates the need to extend the analysis of the socio-structural prerequisites and consequences of migration beyond the established frame of reference with its focus on integration, social inequality and the resulting potential for conflict, without actually being able to offer a sustainable alternative. ${ }^{3}$

This focus in migration research on questions of social integration and inequality has impacted on scholarship in two ways. ${ }^{4}$ For one thing, as in the case of youth studies and inequality studies, migrants were long considered a special case, with no general socio-structural evidential value, and were thus initially left in the hands of migration researchers, and largely excluded from the theoretical and empirical research taking place in these sub-disciplines. It was not until the 1990s that they began to feature regularly in youth and inequality studies, and to be included in survey studies. Migration - this much now seems clear - has consequences for the socio-structural relations of distribution and alters the stratification and class structure and the conditions in which young people grow up. There are few signs, however, that this belated inclusion, which is probably based on a shared normative orientation, ${ }^{5}$ is taking place in other sub-disciplinary fields. 
Migration researchers are interested in education from the point of view of migrants' educational success, but are educational sociologists interested in international migration? Migration researchers are interested in the position of migrants in labour markets and in workplaces, but are labour market researchers and organisational sociologists interested in international migration? Migration researchers are interested in the political and legal position of migrants, but are political sociologists, sociologists of law, political scientists or legal scholars interested in international migration? In all these cases, and the list could easily be extended, the answer would have to be the same: hardly. Why should they be interested in migrants or in international migration? The reason for this lack of interest in the issues investigated by migration researchers is the limited concept of social structure which migration research has hitherto taken as its basis - a concept involving the conceptual exclusion of key socio-structural prerequisites and consequences of migration, as reflected in various areas of society - the economy, law, politics, education, ${ }^{6}$ health, religion and sport - and in the associated organisations and the forms of interaction. Migration, insofar as it is socially significant, has an impact not only or primarily in terms of migrants' access to work, money, rights, education and health, but finds its prerequisites and its effects, where applicable, in the structure of markets and businesses, in political constitutions and administrations, in organisations of the welfare state, in schools and training organisations, in hospitals and doctors' surgeries, in sporting and religious organisations. But what do we know about the significance of migration for the structural development of businesses, local body administrations, schools, training organisations or hospitals? In other words: if migration is important for the structure of society - a claim which, on the one hand, goes unopposed but, on the other hand, is widely ignored in many potential fields of research for which it should be relevant - then this must not only or primarily affect the living conditions of migrants, but also the differentiated social structures of modern society, in which migrants like all other individuals also appear socially as members of organisations and as addressees for political, legal, economic, educational or health-related issues. It is the manner in which they appear here, and the related structural consequences for markets, rights and law enforcement, political decisions, membership roles in organisations or forms of communication in the education and health systems, which make migration and migrants visible as socially relevant facts. This implies for one thing that migration research is not always or predominantly about migrants. It also means, however, that the position of migrants can only be adequately understood if the specific significance of international relations of migration and the inclusion or exclusion of migrants are examined systematically for these differentiated sub-contexts, i.e. with regard to their economic, legal, political and educational issues and the connected 'processes of organising' (Weick 1985). 
Migration research can only establish an academically productive relationship with the other social science disciplines or sub-disciplines and their theoretical and empirical questions if it ceases to limit its area of enquiry to the frame of reference of integration and inequality, as outlined above, and expands its structural-theoretical repertoire in such a way that it can analyse the whole range of structural consequences of migrations in modern society. In other words: the limiting of the concept of social structure to the distribution structure of society and the connected social constellations (traditionally contained in models of class and stratification) must be given up in favour of a concept of social structure which seeks to contain the differentiated social structures of modern society and the resulting relations of inequality. This encourages us to go beyond inequality studies and connect to sociological differentiation theory as a frame of reference for research. For this a conceptually elaborated version is already available, in the sociological systems theory of Niklas Luhmann. Here we find not just a theory of modern society which covers the structure of the differentiated subsections of this society and of its relations of organisation and interaction, but a theory which at the same time allows us to understand international migrations as part of the structural development of the modern, functionally differentiated society and the connected social relations of mobility. This systematically includes the analysis of the social relations of inequality and thus the question of how the reproduction of structured social inequality is to be understood under conditions of functional differentiation (Bommes 2001a, 2004).

In the following this is elucidated in three respects: ${ }^{7}$

1. Systems theory conceives of the relationship between individuals and social systems as a system-environment relationship and thus describes migration as a spatial form of mobility which reacts to the inclusion structures of society.

2. The theory of functional differentiation allows us to impose theoretical order on the forms of migration in modern (world) society. On this basis it becomes apparent that the problem of migration, such as it presents itself to modern society, is based on the organisational form of politics, the fact that the political system is internally differentiated into nation states.

3. Systems theory describes modern society as the interrelation of systemenvironment relationships which are differentiated in themselves. It encourages migration research to check system references when describing migration and the resulting social structures, and to understand such structures as part of the reproduction of the types of system under examination in each case. 
From the point of view of systems theory, the conception of the relationship between individuals and society as a problem of the social integration of individuals (and thus also of migrants) is rejected for theoretical reasons (see below for more on this) and is reconstructed differently as a relationship of inclusion or socialisation (for more detail see Bommes 1999: 43ff.). Thus, migrations are also described through the medium of the concept of inclusion. ${ }^{8}$ This kind of approach is more easily understood if one first notes the similarity with Marxist approaches in this respect. They interpret labour migration in particular as a phenomenon which makes visible specific core structures of capitalist societies, in particular the characteristics of the labour market compared to other commodity markets. Migration is regarded as an occurrence which is pre-structured by social conditions and thus as a form of mobility which reacts to the way capitalism utilises individuals in markets as commodities (labour).

Systems theory takes up this issue in the framework of the theory of functional differentiation and radicalises it. The abstraction already identified in Marx's theory, the utilisation of individuals in terms of 'work' and the disregard for all other attributes, is identified by differentiation theory as a general characteristic not only of the economy, but also of the other function systems of modern society. In politics, in law, education, health, etc., individuals are incorporated as voters, legal parties, students or patients, and utilised without regard for their other attributes. Conversely, individuals can only take up opportunities to participate if they respect these abstractions as prerequisites for inclusion.

Systems theory generally conceives of the relationship between individual and society as a reciprocal relationship between system and environment. In this context the distinction inclusion/exclusion is meaningful mainly in terms of theoretical technique. It is not directly aimed at 'social problems', as is the case for many migration research texts which use this terminology. This distinction is used to describe the manner in which social systems utilise individuals and the way this changes depending on the primary type of differentiation of society (Stichweh 1988; Luhmann 1989). For modern society, primarily differentiated in terms of function, ${ }^{9}$ a core thesis of Luhmann is as follows:

The individual can no longer belong to only one subsystem. [...] Since society $[\ldots]$ is nothing other than the totality of its internal system/environment relationships [...], it no longer offers the individual a place where he can exist as a 'social being'. He can only live outside society, only reproduce himself as a system of its own kind in the environment of society, whereby society is a necessary environment for him. The individual can no longer be defined 
through inclusion, but only through exclusion (Luhmann 1989: 158).

His social individuality consists of the history of his inclusions in and exclusions from the function systems and their organisations. This conception has various implications for (a) the issue of the integration of individuals into society and (b) the question of social inequality.

$A$ From the point of view of systems theory, individuals are not part of society and therefore also not integrated or 'incorporated' into society. The conception of the relationship between individual and society from the perspective of social systems as a relation of inclusion ${ }^{10}$ empiricises the question of individuals' opportunities and impediments to participation in the function systems and their organisations and thus purges them of overly strong assumptions about requirements, whether of society or of individuals, and also of normative premises. The questions considered are: what are the structural prerequisites of the respective forms of differentiation of social systems, and how do inclusion and exclusion then work? The interplay of social systems and individuals is not automatic: inclusion and exclusion can fail, and social systems can come to a dead-end and collapse on the basis of their form of differentiation. Social systems in modern society are dependent on the participation of individuals, but not of any particular individual. Function systems and organisations develop specific modes of inclusion which regulate the participation of individuals in the benefits of the system and stipulate the conditions for exclusion. They work on the assumption that individuals will exercise a certain self-discipline, they demand system-specific skills from them, expect corresponding forms of self-presentation from them and also arrange for their possible exclusion. Conversely, individuals are reliant, for their mental and physical self-preservation, on participating in the communication processes of a multitude of social systems. ${ }^{11}$ Depending on the extent and mode of the offers of inclusion, threats of exclusion and dependencies which exist for them, this is evidently able to mobilise them - even to covering large spatial distances in order to take up such opportunities for participation. The social conditions and forms of this mobilisation ${ }^{12}$ and its consequences for the structures of the function systems and their organisations are the subject of migration research.

$B$ Social inequality, insofar as migration research deals with this subject as a question of the integration of individuals, does not draw attention to the efforts of migrants to take advantage of opportunities for participation and to their inclusion or exclusion in the different function systems and organisations primarily in empirical terms of success or failure because of the structural conditions of these social structures. It therefore also hardly enquires into the structural consequences of the modes of inclusion and of exclusion of migrants for these social systems. Instead, as shown in 
the introduction, in many cases it directly translates the results of these modes into problems of inequality, which it considers to be signs of integration problems. Yet problems of inclusion and exclusion indicate subissues of the reproduction of social systems and do not directly indicate problems of the individuals involved. Connectivity (Anschlussfähigkeit) determines the inclusion or exclusion of individuals, and therefore also of migrants. Their utilisation is subject to one criterion: will it ensure that the system-specific activity can be continued? Problem situations occurring in organisations and function systems, and their management, are not directly and primarily problems of inequality. By approaching migration via the analysis of the relations of inclusion of social systems the problem of inequality is not made to disappear, but it is reintroduced differently in the framework of theory. The investigation focuses on how forms of differentiation, structures of inclusion in functional and organisational systems, and structures of distribution are connected to each other. Inequality can then turn out to be a condition for migrants' opportunities for inclusion (Bommes 1999: 198ff., 2004), as is shown at present by so-called illegal migrants, whose specific chances of inclusion in various labour markets are based not least on their limited capacity for conflict, the resulting willingness to provide services for relatively low pay, and a demand which develops on this basis.

To sum up: from the point of view of systems theory the primary form of differentiation and the related forms of inclusion of a society structure individuals' opportunities for social mobility and therefore also migration as a spatial form of mobility offering chances for inclusion. The theory can show that migrations and forms of migration in modern society have as their prerequisites the exclusion of individuals (their freedom from prior commitments $^{13}$ and their equality in the sense of a disregard for particular characteristics) and at the same time the universalism of inclusion of the function systems and organisations (anyone who fulfils the system-specific prerequisites for inclusion is admitted) and are induced by them. This is immediately clear for labour migration, educational migration, sports migration or the migration of the sick. But it can equally be shown for family migration, where the right to access to the family is exercised, and through this, chances for inclusion in other function systems are gained, and it can also be shown, finally, for refugee migration on the basis of international refugee law, which repairs the breaches in the universalism of inclusion committed by states.

With this in mind it becomes clear at the same time that migration research typically deals with issues which are the result of migration as a quest for access to organisations and function systems and from the structuring of this quest through its conditions of inclusion. It is characteristic of migration research that it takes an interest in the consequences arising from such attempts for the migrants, the immigration and emigration 
contexts, and the newly developing social structures. This explains the fact that it does not usually deal with other forms of spatial mobility such as tourism or the migration of individuals as members of organisations (e.g. managers). This does not imply a judgement about the social significance of such forms of spatial mobility. But if one formulates the frame of reference of migration research in terms of its typical issues, it becomes superfluous to introduce the sociology of migration by means of a list of the various kinds of spatial mobility, and limit this list based on those features relevant to the migration being examined (e.g. Treibel 1999: 18ff.). The starting point should be the social structures which facilitate spatial forms of mobility. The latter, even when they bear similarities, as for example with commuter migration and tourism, do not in every case constitute migration as it is understood by a branch of research which is concerned with an academic problem, and not one established by empirical characteristics of spatial mobility. ${ }^{14}$

\section{III}

Regardless of their individual motivation, migrants must follow the social, i.e. communicative, opportunities for connection which are offered by function systems and their organisations. ${ }^{15}$ The political treatment of the conditions of their immigration is of central importance for the manner in which they achieve this connection - be it as labour or educational migrants, as citizens or refugees.

With the theory of functional differentiation it is possible to reveal a social contradiction in modern society in relation to this. Here migration is, on the one hand, probable as an attempt to take advantage of opportunities for inclusion. In terms of the economy, the law, education or health, and of modern organisations, migration is something individuals can be expected to do to adjust to the forms of inclusion on offer to them. Migration is therefore part of the normal, i.e. socially expected mobility in modern society, which has historically been implemented, for example, with the institutionalisation of labour markets. The case of internal migrations within states' territories makes this clear. They are part of normal events that hardly mobilise social attention. Migration is, on the other hand, manifestly treated as improbable and as a problem, particularly in those countries with fully developed nation states and welfare states, when migration crossing state boundaries is involved.

Thus, migration only becomes a problem when viewed in terms of politics. This draws attention to a characteristic of this function system in comparison to the other function systems, a characteristic which underlies the specific manner in which politics monitors migration. The function system of politics is internally characterised by a segmental internal differentiation 
into modern national welfare states. Despite all its structural problems, this statehood has been until now and will remain into the foreseeable future the more or less indispensable form of organisation of the function system of politics for the production of collectively binding decisions. An essential structural consequence of this internal differentiation is the specific form of inclusion of national citizenship, which is, unlike the other forms of inclusion, exclusive, permanent and immediate. The related particular universalism envisages the inclusion of every individual into one, but only one state. The form of inclusion of citizenship provides the historic foundation for what is, in principle, a lifelong relationship of service and loyalty between the state and its citizens, which is institutionalised in the national welfare state and which obliges the state, when making its political decisions, to be guided by the community (Gemeinschaft) of the citizens and their claim to equality as members of the people or nation (Volk).

International migration calls into question the political division of the world population into state populations, and places migrants in a structurally precarious relationship with national welfare states in the dimensions of loyalty and service. The relationship between national welfare states and migration and migrants can be deciphered in these two dimensions. The state, as a nation state, monitors migrants in terms of their political loyalty. The state as a welfare state, i.e. as a mechanism for achieving internal social balance, erects a barrier of inequality toward the exterior, which is crossed by migrants. Socially, this provokes the question of their relationship to the services of the welfare state. The national welfare state therefore intervenes in the forms of migration in modern society with a view to upholding the relationship of loyalty and service to the community of citizens. Based on this criterion, it becomes the filter for migrants' attempts to take advantage of opportunities for inclusion in the function systems and their organisations by means of geographical mobility. At the same time, with this and with the creation of differentiated categories of immigrant, it establishes a frame of reference in which national or ethnic semantics of community can evolve for expressing and carrying on conflicts about migration.

With Europe's development into one of the major immigration regions of the world, however, the historical improbability of a congruence between people and population (Volk and Bevölkerung) in the national welfare state becomes more obvious (for more on the following see Bommes 2003b). The difference between the state's 'core population', the citizens as the people (Volk), and the 'residual population' of migrants becomes the norm, and this makes the distinction itself precarious. States must, on the one hand, redefine their territorial sovereignty in relation to supranational and international ties; on the other hand, international migration articulates a context in which social processes in the areas of the economy, law, education and training, scholarship, sport, health, but also family are still 
indexed to state territory, but not limited to this. The erosion of the division of the world population into state populations by means of international migration expresses this fact and thus undermines the difference between people and population (Volk and Bevölkerung). This distinction always also meant the establishment of territorial barriers of inequality by states. International migration is not only an expression of the successful overcoming of these welfare-state barriers of inequality by migrants. It is simultaneously part of an inner restructuring of the relations of distribution and inequality in welfare states themselves. This restructuring involves an increased internal differentiation of the addressees of welfare-state policy and the political semantics of the way they are addressed.

In conditions of globalisation of 'competitive states' and of considerable problems of demographic structure, national welfare states are confronted with political problems in the reorganisation of their social security systems, not least because of their limited enforcement capabilities with regard to raising resources. Part of this reorganisation is the reconstruction of the relationship between states and their populations, in which they, on the one hand, take back the promise of service to their state population as 'people' or 'nation' (Volk), and establish an internal differentiation between a productive and a less productive, peripheral population. Migrants fall into both categories and thus point to a problem - the controversy over which criteria should, in future, be taken as constitutive for the relationship of loyalty and service between states and their populations, if states not only repel migrants but at the same time court them, in order to increase the productive portion of their population.

\section{IV}

Migration research usually defines its object as the study of the consequences of migration in the immigration and emigration context. Systems theory encourages us to make these contexts more specific with regard to system references. For the study of migrants' opportunities for inclusion and of their careers as a cumulative result of the history of their inclusions, this means not looking exclusively or primarily at the migrants' attributes as their individual prerequisites for inclusion, but examining the systemspecific structural conditions in which migration, or migrants and their resources, make their impact.

Thus, for example, organisations as recursive decision-making contexts each develop organisation-specific traditions. Hence there is a need to investigate in what way political administrations (see Bommes 2003c), or organisations in the education system have any leeway to determine what a migrant is when dealing with their problems, what the relevant administrative or educational problem is in each case, and what resources should be 
used in response, etc. Regardless of how such organisations use this leeway, what is systematically significant is that, in using this leeway, they mainly solve their own problems. By passing on, postponing or solving their own particular decision-making problems, they define what sort of a problem migration is, what the resulting political or educational consequences are, how migrants are to be dealt with against this background, what positions are assigned to them, and whether they can participate or not.

Finally, two implications of the above should be pointed out:

1 Socially, migration does not designate a kind of 'compact event' which manifests itself in social effects on the social structures of society. The reality of migrants' lives is determined, like that of all other individuals, by participation - which must, in a sense, be secured anew every day - in the differentiated structures of society, something which is obscured if the problem is formulated as 'social integration into society'. Migration and social participation succeed or fail politically, economically, legally, and in terms of education and health, etc., in different ways, lead in various combinations to different results, and are connected with different issues and modes of reaction and processing in the various areas. If, as set out above, one understands international migration in modern society in formal terms as a form of social mobility to take advantage of opportunities for participation in the areas of modern society which are relevant for one's lifestyle, then migrants succeed in taking up these opportunities to differing extents, dependent on their individual prerequisites and on the reception structures of society, which are differentiated politically, legally, economically, educationally, religiously, etc. In these various areas - in quite different ways - decisions are made in the course of migration processes about what kind of issues migration involves, in political, legal, economic, etc., terms, and how these are to be dealt with. Generally speaking, it is important to examine the varying social options for migrants to participate in the differentiated social structures of society, and the various forms of combination, in terms of their effects both on these social structures and on the course of migrants' careers of social inclusion.

2 Starting at this point, the issue of integration can at the same time be taken up again in a different way. Research on the integration and assimilation of migrants has shown that the penetration of migrants into the distribution structures of modern society and the connected structured relations of inequality, which are still, in the richer countries, strongly indexed to the nation state, has a largely regular structure, and that the relations of assimilation are therefore relatively firmly coupled or integrated: in the course of its history, migration research has not always ascribed exactly the same meaning to assimilation. In general, however, it has assumed a more or less close correspondence between the dimensions of assimilation which it distinguishes. ${ }^{16}$ 
More recent research in transnationalism can essentially ${ }^{17}$ be understood as an empirical questioning of the nation state's role in mediating the strict coupling or integration between the various forms of assimilation. Through claiming that transnational relationships are expanding, this research suggests that the social systems in which individuals participate are not confined to the nation state. ${ }^{18}$ Accordingly, the lifestyle of individuals can also be oriented towards a more or less constant crossing of state boundaries: again this can affect a wide variety of areas such as family, education, health, economy or politics. As an example: migrants can work in their place of immigration, in order to invest the money in their context of origin, to provide for their families, and to get involved in local or national political projects there. As successful migrants, they can invest money in the region of origin and build up relevant industries, as in the case of Indian IT specialists. These transnational forms of lifestyle occur in different combinations on the basis of the different resources available to migrants, and in different social contexts (see e.g. Hunger 2000; Levitt 2001; Müller-Mahn 2000; Singhanetra-Renard 1992). Against this background the central message of transnationalism is basically this: empirically, in the process of progressive globalisation and in conditions of transnationalism, a decoupling or even disintegration of the various forms of assimilation can be observed, and new possible variations between them are emerging. The nation state frame of reference is becoming less important for integration, i.e. there is less limitation of the room for variation in the forms of assimilation. In systems theory terms this controversy can be conceptualised as an enquiry into the connection between the differentiated structural development of the various subsystems of modern society and the more or less strong integration of migrants' careers of inclusion in these systems as well as the access to social resources which is mediated through this.

Overall, then, the analytical potential of systems theory allows us to study migrations as social phenomena in a differentiated way, with regard to the social systems in which they become relevant. It is therefore necessary to specify whether empirical analyses of migration and its consequences are situated on the level of function systems, organisations or interactions. Instead of studying migration as a 'shift into another society' (Treibel 1999: 21), distinguishing system references makes it possible to research migration in world society on various levels: the attempts of migrants to take up opportunities for inclusion in function systems and their organisations by means of geographical mobility; the differentiated economic, political, legal or educational consequences of each of these attempts; the organisations which are created in regions of origin and target regions as a result; and finally, the changes in structures of interaction which, attached to the observation of discrepant forms of communication and structures of expectation, are registered in migration research as a cultural difference or as a problem of intercultural relations. 


\section{Notes}

I At the same time migration research claims to have an interdisciplinary orientation. Yet in many cases it remains unclear what on the one hand constitutes its specific contribution to each discipline, and what exactly, on the other hand, the 'inter' is referring to. What seems to play a defining role is the widely shared normative agreement about the (political) significance of the problems of integration, inequality and conflict.

2 It is therefore not necessary, in the light of their nature as values, to define with any great precision what is meant, in each case, by social integration and inequality.

3 Beyond the plausibility of everyday examples, it is not clear what social structure a social space designates in practical terms, why this should be thought to generate a suitable, general frame of reference for the analysis of migration and its socio-structural implications (instead of a concept of society based on the nation state), and precisely what, in analytical terms, is distinguished by the 'four dimensions of sociospatial incorporation' (economic, social, cultural, political), beyond the claim to complete originality and novelty; cf. Pries 2003. For a more detailed treatment of this see Bommes (2003a [chapter 5 in this volume]).

4 The political aspect is not taken into consideration here; it is striking, however, that the frequently encountered preference among migration researchers for integration and equality has met with a certain political impatience in recent years (for this see Luft 2003). There are many reasons for this, not all to be found in the scientific practice of the migration researchers; some can certainly be sought in the fact that researchers have often failed to clearly distinguish between scientific statements and politically normative ones.

5 For inequality studies Geißler (I996) recalled this normative framework of inequality studies in a discussion of the debate on so-called new inequalities - and the position of migrants in the relations of distribution in Germany then becomes a systematic indication of increased relations of inequality, if it can no longer be regarded as transitory.

6 It was left to the PISA study to point out that the success of migrant children in the education system is heavily dependent on the structure of the respective national forms of organisation. Opinions differ on what conclusions are to be drawn from this in educational and migration research, but in any case it draws attention to the connection between migration, forms of organisation in the education system, and their social effects.

7 What follows is the expanded and revised version of a text which appeared in the Schweizerische Zeitschrift für Politikwissenschaft (Swiss Journal for Political Science) (Bommes 200Ib).

8 This is not so much a question of terminological differences, but the systematic meaning of conceptual distinctions. The manner in which the problem of integration and assimilation is conceived in the work of authors who argue on the basis of assimilation theory or with reference to new transnational conditions of integration, and their differences and points of agreement, can be systematically made transparent in the frame of reference which is about to be explained; cf. Bommes $2003 \mathrm{a}$.

9 In principle, all structures of action or communication are to be regarded as societal structures, as long as every action or communication with its specific characteristics is also always the implementation, the process of society, and linked with this, the establishment of an expectation with regard to what might happen next. In sociology, however, the designation 'social structure of society' usually means more, i.e. the identification of primary structures or differences which make possible and limit the development of further structures or differences. From a differentiation theory 
perspective, the term 'form of differentiation' has designated these primary structures since Marx, Weber and Durckheim (Schimank 1996). In competition with this is a concept which takes as its basis the distribution structure of a society and the resulting social structures (classes or strata) as the primary form of differentiation (Schwinn 1998). For the related problems and a more precise treatment of the limitations of the social structure concept of inequality research, also with reference to its own questions, cf. Bommes 200Ia.

Io From the perspective of individuals this is about socialisation, the structural development of psychological systems through participation in communication.

II In this sense, none of the individuals in modern society has any alternative to assimilation.

I2 This includes, for example, the expansion of modern media of dissemination and the worldwide consolidation of a low-cost transport network, the emergence of communication networks by means of chain migrations and resultant changes in expectations about how individuals can legitimately be utilised. These individuals are thus confronted with migration as an unreasonable expectation (e.g. ensuring the livelihood of their families by taking up unfamiliar opportunities for inclusion in distant labour markets) and as an opportunity (to thereby escape utilization by their families). For the ambivalences triggered by this cf. Thomas \& Znaniecki I958 (I9I8/ 2I).

I3 Migrations are to be found in all societies, but are differently structured depending on the primary form of differentiation. In estate-based societies the individuals and their social options for inclusion are defined by estate affiliation determined by descent. This also regulates their options for migration as tradesmen, students or pilgrims and, precisely for this reason, turns the migration of the excluded, the poor, beggars and vagabonds, into a threat (Bommes I999: $58 \mathrm{ff}$.).

I4 One can show using the politically topical example of the so-called (German) Green Card and its supposed failure that the international migration of computer specialists largely occurs as migration on the basis of membership of organisations. It indicates a problematic aspect of the possibility of deploying personnel flexibly in globally operating businesses and is therefore also largely unrelated to the usual problems which migration research examines as problems of social integration, since these businesses make it possible for their personnel to be flexible by providing corresponding social conditions such as access of family members to education, healthcare, etc. This form of international migration on the basis of organization membership can be understood here as part of the globalisation of businesses in the specific conditions of the training and recruitment of personnel in the IT field; for a closer treatment see Kolb 2003; Kolb \& Hunger 2003.

I5 Every asylum seeker knows this; if he wants to get through the administrative procedure for checking his asylum claim, he must carefully separate the communicated motives from other possible motives, with regard to their connectivity.

I6 Cognitive, structural, social and identificative assimilation; cf. Esser I980, following Gordon. This is plausible at first glance: someone who brings more cognitive prerequisites will be able to fulfil more differentiated role requirements. Someone who has a secure and more or less well paid occupational position will have easier access to health, education, law and politics, will meet with more social recognition and will be better placed to enter into social contacts in this environment. And someone who moves in these kinds of social context can in turn build up corresponding cognitive structures, etc. The opposite also applies: it appears unlikely that one would gain, in a narrow ethnic milieu, the cognitive prerequisites needed to fulfil the requirements of school or to be professionally successful and thus be recruited for attractive, well-paid positions in organisations. Working on this assumption, it is also 
improbable that one would gain access to corresponding social networks, friendships or clubs or that one would feel one belonged in other contexts than one's own narrow milieu. Both the successful assimilation to the expectations of social systems and the failure to assimilate seem to have a highly self-stabilising character.

I7 And beyond its theoretical obscurities.

I8 The theory of functional differentiation works on this assumption anyway, and is therefore conceived as a theory of world society (Stichweh 2000).

\section{References}

Auernheimer, Georg (2003), Einführung in die interkulturelle Pädagogik. Darmstadt: Wissenschaftliche Buchgesellschaft.

Bommes, Michael (1999), Migration und nationaler Wohlfahrtsstaat. Ein differenzierungstheoretischer Entwurf. Opladen/Wiesbaden: Westdeutscher Verlag.

Bommes, Michael (2001a), 'Organisation, Inklusion und Verteilung. Soziale Ungleichheit in der funktional differenzierten Gesellschaft', in Veronika Tacke (ed.), Organisation und gesellschaftliche Differenzierung, Wiesbaden, pp. 236-258.

Bommes, Michael (2001b), 'Migration in der funktional differenzierten Gesellschaft', in Schweizerische Zeitschrift für Politikwissenschaft, 7/2, pp. 108-116.

Bommes, Michael (2003a), 'Der Mythos des transnationalen Raumes. Oder: Worin besteht die Herausforderung des Transnationalismus für die Migrationsforschung?' in Migration im Spannungsfeld von Globalisierung und Nationalstaat (Leviathan Sonderband 22), Dietrich Thränhardt \& Uwe Hunger (eds). Wiesbaden: Westdeutscher Verlag, pp. 90-116.

Bommes, Michael (2003b), 'The Shrinking Inclusive Capacity of the National Welfare State: International Migration and the Deregulation of Identity Formation', in Grete Brochmann (ed.), The Multicultural Challenge (Comparative Social Research 22). Oslo: Elsevier, pp. 43-67.

Bommes, Michael (2003c), 'Die politische >Verwaltung ‘ von Migration in Gemeinden', in Jochen Oltmer (ed.), Migration steuern und verwalten. Deutschland vom späten 19. Jahrhundert bis zur Gegenwart (IMIS-Schriften 12), Osnabrück, pp. 459-480.

Bommes, Michael (2004), 'Zur Bildung von Verteilungsordnungen in der funktional differenzierten Gesellschaft - erläutert am Beispiel »ethnischer Ungleichheit« von Arbeitsmigranten', in Thomas Schwinn (ed.), Differenzierung und soziale Ungleichheit. Die zwei Soziologien und ihre Verknüpfung, Frankfurt am Main, pp. 399-428.

Bommes, Michael \& Andrew Geddes (eds) (2000), Welfare and Immigration. Challenging the borders of the Welfare State. London: Routledge.

Bommes, Michael \& Jost Halfmann (eds) (1998), Migration in nationalen Wohlfahrtsstaaten. Theoretische und vergleichende Untersuchungen. Osnabrück: IMIS.

Castles, Stephen (1987), Migration und Rassismus in Westeuropa, Berlin.

Castles, Stephen \& Godula Kosack (1973), Immigrant Workers and Class Structure in Western Europe. London: Oxford University Press.

Dohse, Knuth (1981), Ausländische Arbeiter und bürgerlicher Staat. Genese und Funktion von staatlicher Ausländerpolitik und Ausländerrecht. Vom Kaiserreich bis zur Bundesrepublik Deutschland. Königsstein im Taunus: Athenaeum.

Esser, Hartmut (1979), Arbeitsmigration und Integration: sozialwissenschaftliche Grundlagen. (Materialien zur Arbeitsmigration und Ausländerbeschäftigung 4). Königstein/Taunus: Hanstein.

Esser, Hartmut (1980), Aspekte der Wanderungssoziologie. Darmstadt and Neuwied: Luchterhand.

Faist, Thomas (1995), Social Citizenship for Whom? Young Turks in Germany and Mexican Americans in the United States. Aldershot: Avebury. 
Geißler, Rainer (1996), Die Sozialstruktur Deutschlands. Opladen: Westdeutscher Verlag.

Hammar, Thomas (ed.) (1985), European Immigration Policy. A Comparative Study, Cambridge: Cambridge University Press.

Herbert, Ulrich (2000), Geschichte der Ausländerpolitik in Deutschland. Saisonarbeiter, Zwangsarbeiter, Gastarbeiter, Flüchtlinge. Munich: C.H. Beck.

Hoffmann-Nowotny, Hans-Joachim (1973), Soziologie des Fremdarbeiterproblems. Eine theoretische und empirische Analyse am Beispiel der Schweiz. Stuttgart: Enke.

Hunger, Uwe (2000), 'Temporary Transnational Labour Migration in an Integrating Europe: The Challenge to the German Welfare State', in Bommes \& Geddes (eds), Welfare and Immigration, pp. 189-208.

Kolb, Holger (2003), 'Pragmatische Routine und symbolische Inszenierungen - zum Ende der >Green Card', Zeitschrift für Ausländerrecht und Ausländerpolitik 7, pp. 231-235.

Kolb, Holger \& Uwe Hunger (2003), 'Von staatlicher Ausländerbeschäftigungspolitik zu internationalen Personalwertschöpfungsketten?' WSI Mitteilungen 4, pp. 251-256.

Körner, Helmut (1976), Der Zustrom von Arbeitskräften in die Bundesrepublik Deutschland 1950-1972. Auswirkungen auf die Funktionsweise des Arbeitsmarktes. Frankfurt am Main and Munich: Peter Lang.

Levitt, Peggy (2001), The Transnational Villagers. Berkeley: University of California Press.

Luft, Stefan (2003), Mechanismen, Manipulation, Mißbrauch. Ausländerpolitik und Ausländerintegration in Deutschland, Cologne.

Luhmann, Niklas (1989), 'Individuum, Individualität, Individualismus', in idem, Gesellschaftsstruktur und Semantik. Studien zur Wissenssoziologie der modernen Gesellschaft 3. Frankfurt am Main: Suhrkamp, pp. 149-258.

Miles, Robert \& Dietrich Thränhardt (eds) (1995), Migration and European Integration: The Dynamics of Inclusion and Exclusion. London: Pinter.

Müller-Mahn, Detlef (2000), 'Ein ägyptisches Dorf in Paris. Eine empirische Studie zur SüdNord-Migration am Beispiel ägyptischer »Sans-papiers« in Frankreich', in IMIS-Beiträge 15 , pp. 79-110.

Pries, Ludger (2003), 'Transnationalismus, Migration und Inkorporation. Herausforderungen an Raum- und Sozialwissenschaften', in Geographische Revue 2, pp. 23-39.

Sassen, Saskia (1988), The Mobility of Labour and Capital: A Study in International Investment and Labour Flow. Cambridge: Cambridge University Press.

Schimank, Uwe (1996), Theorien gesellschaftlicher Differenzierung. Opladen: Leske + Budrich.

Schrader, Achim, Bruno W. Nikles \& Hartmut M. Griese (1976), Die zweite Generation. Sozialisation und Akkulturation ausländischer Kinder in der Bundesrepublik Deutschland. Kronberg.

Schwinn, Thomas (1998), 'Soziale Ungleichheit und funktionale Differenzierung. Wiederaufnahme einer Diskussion', in Zeitschrift für Soziologie 27, pp. 3-17.

Singhanetra-Renard, Anchalee (1992), 'The Mobilization of Labour Migrants in Thailand: Personal Links and Facilitating Networks', in Mary M. Kritz et al. (eds), International Migration Systems: A Global Approach, Oxford: Clarendon Press, pp. 190-204.

Stichweh, Rudolf (1988), 'Inklusion in Funktionssysteme der modernen Gesellschaft', in Renate Mayntz et al. (eds), Differenzierung und Verselbständigung. Zur Entwicklung gesellschaftlicher Teilsysteme. Frankfurt am Main/New York: Campus, pp. 261-293.

Stichweh, Rudolf (2000), Die Weltgesellschaft: Soziologische Analysen. Frankfurt am Main: Suhrkamp.

Thomas, William I. \& Florian Znaniecki (1958), The Polish Peasant in Europe and America. New York: Dover (first published 1918/1921).

Treibel, Annette (1999), Migration in modernen Gesellschaften. Soziale Folgen von Einwanderung, Gastarbeit und Flucht. Munich: Weinheim.

Weick, Karl E. (1985), Der Prozess des Organisierens. Frankfurt am Main: Suhrkamp. 



\title{
2 National welfare state, biography and migration
}

\author{
Labour migrants, ethnic Germans and \\ the re-ascription of welfare state membership
}

First published in 2000 by Routledge as a chapter in Welfare and immigration: Challenging the borders of the welfare state (pages 90-108), edited by Michael Bommes and Andrew Geddes

\section{Introduction}

In modern society individuals are not 'members of society'. The chances to become included in different social realms - the economy, law, politics, education, health and the family - are no longer based on descent, or belonging to a social strata, or to an ethnic or religious group. It is individuals themselves that principally achieve inclusion in these different social realms and the risks of failure are high. Consequently, if we understand modern national welfare states as organisational complexes which try to heighten the chances of inclusion and minimise risks of exclusion for their citizens, then one central structural form of providing inclusion has been the institutionalisation of the modern life course (Kohli 1985). In this chapter, I discuss the reasons why this institutionalisation of the life course and the safeguard within it of individuals with a structured biography have become central for the mode of operation of welfare states. I then show that migrations that transgress state borders highlight some very specific social preconditions of these arrangements for inclusion. If biographies are understood as the result of a sequential process in which chances for social participation, supported by welfare states, are accumulated, then migrants are likely to be structurally poor because of their specific relation to national welfare states.

The chapter then develops these core observations with a case study of the immigration of ethnic Germans and labour migrants in Germany. It demonstrates that migration makes some of the structural preconditions of the modern life course regime visible. It also shows that migration can be taken as part of a process that erodes the classical arrangement by which 
welfare states provide an ordered life course for the members of the national community, i.e. for their citizens, in exchange for political loyalty.

\section{The 'social construction' of biographies through organisations}

The participation of individuals in modern society is no longer based on a unitary principle of inclusion and exclusion. The social conditions of inclusion, i.e. the mode by which individuals become engaged, are defined by the differentiated social systems of society: the economy, the law, politics, education or health. If individuals fulfil the functionally specific requirements of these systems then they are included. Individuals are perceived in relation to their relevance to these social systems, everything else is left out of account. This means that social inclusion in modern society presupposes the exclusion of individuals as 'totalities' from society in the sense that they are not predefined by social bonds or some principle of belonging (Luhmann 1989, 1995). Instead, in modern society, individuals become socially defined by their personal histories of inclusion and exclusion in different social realms.

Inclusion occurs as a result of their biographies. These are an invention unknown to former societies differentiated by strata, which defined individuals by inclusion and social belonging. A central point is that if traditionally it was social belonging that defined the social options of the individuals, then in modern society it is biographically accumulated social options that define social belonging. The definition of an individual becomes selfreferential in that the individual is what he or she has become. The identification of individuals thus changes from the observation of social belonging to a temporal form of observation that can be characterised as the development of the individual in time (Hahn 1988). As an effect of this shift, the past of individuals - their biographies - carry the information, which allows the building of expectations about their future options. For instance, whether or not an individual is suited for future inclusion in economic, educational, scientific or legal processes.

An early historical experience of modern society was the high risk of failure of social participation connected with these new structural conditions of inclusion. There was no automatic inclusion of individuals in society. Pre-modern stratified orders of inclusion had ascribed the individuals to the strata of society and dealt with the poor, i.e. the 'fallen' individuals who were seen as a constant threat to social order, by a mixture of mercy and violent repression (Fuchs 1997). The breakdown of this order and of the corresponding local poor relief systems provided historically one of the most relevant contexts for the expansion of the modern nation state which eventually sought to deal with the political mediation of the socially restructured chances of inclusion and exclusion (De Swaan 1988; Bommes 
1999). The effect was that national welfare states became the worldwide institutionalised form of organisation of the political system and, with their emergence, they have evolved as international 'thresholds of inequality' (Stichweh 1998). This means that they have provided for the internal loyalty of their citizens by a welfare policy that promotes chances for inclusion based on external closure and exclusion. Historically, welfare state organisations have been established as a reaction to the political claim for not only formal, but also substantial equality for all members of the national community. This claim was founded in the political form of membership, i.e. of citizenship (Marshall 1950). Since then, however, the political semantics of solidarity and substantial equality have been eroded. Empirically, it is clear that social differentiation and individualisation processes rather than equality have been promoted by welfare states (Pierson 1993, 1995).

A central part of this promotion of differentiation and individualisation as a precondition and as a result - was the institutionalisation and safeguard of a modern life course, of individual biographies and, related to this, the concept of a 'career'. These social forms permitted observation of the personal past that was then usable for building expectations about the future. When exclusion and the freedom from inherited social bonds becomes the precondition for inclusion in functional systems and organisations, then security of expectations in relation to individuals and their behaviour can no longer be gained from their social descent and belonging. It can only be gained from their lived sequences of inclusions. This can be conceptualised as the life course with related social biographies and identities. Biographies can be told and individuals are expected to present themselves and their identities in a biographical form. ${ }^{1}$ This institutionalisation of the life course, of individual biographies and careers, is a result of the way in which modern organisations recruit members and of the moderation of these organisational processes of social inclusion and exclusion through the welfare state.

Finding employment in modern society involves offering competence and specific services to an organisation in exchange for payment and other rewards. As a particular type of social system, organisations rely on the formal definition of membership that distinguishes between members and non-members. By engaging individuals as members, organisations distribute conditions and chances for the inclusion and exclusion in other social spheres. For instance, the recruitment of personnel and the allocation to them of positions and careers in organisations are linked with the distribution of money, reputation and influence or - in the words of Bourdieu economic, cultural and social capital. Organisational memberships that are based on careers open up and mediate differential chances for individuals to receive services and resources as, for instance, consumers, patients, clients, pupils and electors. These organisational ways of allocating positions 
and incomes form one central frame of reference for welfare state policies, which aim to increase and, especially, secure the transferability of chances. That is, to seek to ensure that organisational membership equips individuals with the necessary means and rights to provide options for participation in the differentiated social realms of the economy, education, law, health, politics and the family. ${ }^{2}$

One main form to secure this transferability was the institutionalisation of the life course. The life course can be understood as a complex of social rules that order the time dimension of an individual life viewed as a sequential programme (Kohli 1986). 'Biography' and 'career', both of which are central elements of the social concept of a life course, are historically formed by the interplay of modern organisations recruiting members, and the welfare state establishing social preconditions for the possibility to find and recruit members with an expectable life course. ${ }^{3}$ The introduction of social insurance schemes had the effect of organising around the employment of individuals in organisations the temporal accumulation of social entitlements. This depended to a large extent on the duration of employment, changes in the conditions of employment and dismissal, the institutionalisation of public education, the provision of family and education allowances. All these welfare state measures can be understood as structural elements of the institutionalisation process of the life course. From this perspective it becomes clear that life becomes socially conceptualised as a sequential programme partitioned into three general stages: childhood/education, foundation of a family and working life, and retirement. Related to this structuration of life, the family then takes on the form of the modern nuclear family.

Welfare state measures orient individuals towards the structures of a life cycle. The core institutions of the welfare state are structured in a way that implies the expectation that individuals are prepared and willing to prepare themselves for a biographically ordered sequence of inclusions in different social realms and their organisations. The enforcement of this expectation is historically successful since it provides social requirements for both organisations and individuals.

For organisations the welfare state creates the social preconditions allowing individuals that fulfil the necessary requirements to then be observable in the form of a 'career' (Corsi 1993). The welfare state backs up the likelihood that careers can be built. The 'career' maintained by organisations relies on the assumption that a 'normal biography' can be realised. This means participation and access to education, work, the family, as well as to economic, legal, political and health resources. Participation in each single context implies the fulfilment of certain preconditions that are provided elsewhere. For example, education presupposes that pupils have families, have access to economic means to fulfil their needs (through their parents), have a right to be educated and are healthy. Moreover, the education system has gained universal competence for this task and the specification of 
educational problems. The same is valid for other realms such as the economy, ${ }^{4}$ law and health, which rely on the assumption that different problems are dealt with in other social contexts. The less this is empirically the case, the more likely it is that there will be exclusionary chain reactions. Modern welfare states can be understood as institutional arrangements attempting to intervene in this kind of 'spillover' effect ${ }^{5}$ by establishing and accompanying the life course in order to provide the necessary conditions for the chance to build an ordered course of life.

For individuals the social expectation that they lead their lives oriented to a biographical order structured by the social conditions of inclusion and related welfare state programmes, offers the chance of social continuity and orientation. The duty to be an individual with a specifiable and personal biography and identity (see also Strauss 1959) is equipped with a social form. In this way, welfare organisations not only constitute the life course as a social form, they provide a structure for the lifelong relation between the state and the individual. This relation is founded in the specific inclusion form of the political system, which is national citizenship. National citizenship designates a relation between the individual and the state which is exclusive, immediate and permanent (Grawert 1984). A core element of the successful establishment of state sovereignty over the population on their territory - circumscribed as a national community - has been the acknowledgement of state responsibility for the assurance and structuration of the chances to lead a life as a member of that community. ${ }^{6}$ The institutionalisation of the life course and its variations in different welfare states can be taken as the result of the specific historical formation of the relation between each state and its citizens.

What effects does international migration have on an arrangement in which national welfare states provide chances for their citizens to realise an ordered life course? Recent migration research has concentrated on the question of whether migration undermines the capacity of national welfare states to control their territory and to maintain levels of provision. In this context, the ways in which political and legal restrictions seek to reduce the capacity of migrants to collect social entitlements has been analysed (Miles and Thränhardt 1995). This chapter's focus on the relation between the welfare state, biography and migration addresses three questions. First, what kind of positions do migrants have in the life course regimes of welfare states? Second, what kind of effects does immigration have on the structure of institutionalisation of the life course provided by national welfare states? Third, does immigration change the relation between the welfare state and the collectivity that has been historically constructed as the national community of legitimate welfare receivers? Before we shift to the empirical example of the immigration of labour migrants and ethnic Germans (Aussiedler) in Germany, it is necessary to provide a more general consideration on the relation between migration, biography and the welfare state. 


\section{Welfare states and the 'social deviation' of migrants}

The constitution of biographies and their moderation by the welfare state makes the deviation of the biographies of migrants very likely. Deviation means that their life courses and biographies do not fulfil the institutionalised expectations of normality. Consequently, migration puts in view some of the social preconditions of the relation between differentiation and the individual biography/career as a social form. If we understand biographies and related careers as the accumulation of structural participation chances, then migrations make this precondition visible since migrants are presumably structurally poor or deprived and it cannot be assumed that careers with the required elements have been built. Consequently, those things that under 'normal conditions' are treated as given can no longer be presupposed. In other words, established abstractions need revision. This becomes obvious if one looks at some common deviations of migrants in three biographically central dimensions: education, labour, and participation in pension schemes.

- Education: migrant children have access to schools in many countries even when they do not have a residence permit. This permits analysis of the legal and political conditions of education and the education system's assumption that families of children are settled. Migrant children (with or without legal status) may not speak the official language and, in this way, question institutionalised assumptions about normal socialisation processes, as well as linguistic and cultural competencies as central preconditions for the ability to learn something. Moreover, careers of migrant children built at school in their countries of origin may not be accepted by the education system in the immigration country. This may close important paths of educational success and increase the likelihood of failure.

- Employment: labour migrants are less likely to be able to offer socially established biographies and careers of education and work. This excludes them from competition in large segments of the labour market. It should be noted, however, that the absence of careers and related social claims were in many respects the precondition for the immigration of labour to western European countries during the post-war period. In this case the absence of a career provided the chances of social inclusion for labour immigrants on those market segments which were in need of unqualified workers. The same holds true for major parts of illegal immigration.

- Retirement: migrants can access welfare entitlements even if they are not citizens. Older migrants, however, are likely to have low pension incomes since many have not been included long enough in pension insurance funds to accumulate adequate entitlements. ${ }^{7}$ For those reasons it is likely that many will rely on public assistance. 
These three brief examples go to show that the modes by which migrant biographies may deviate from expectations guaranteed by welfare states, and the social meanings and consequences this may have, cannot be purely theoretically derived. The social observation of deviation and its consequences depends upon the various kinds of expectations of normality supported by different types of welfare state. Moreover, immigration takes on different forms in immigration countries and migrants have varying legal status and welfare entitlements linked to their immigration path. Finally, as a result of the different histories of immigration in the various national welfare states we find specific combinations of welfare and immigration regimes.

To illustrate these points, the discussion moves on to an empirical example of the immigration of ethnic Germans (Aussiedler, literally 'outsettlers' or 'resettlers') after the Second World War and to compare their structural position in the German welfare state with the position of the labour immigrants of the Gastarbeiter period. Are both groups included in the provisions of the German welfare state to an extent that allows these migrants to develop some security of expectation concerning their future life course? This is found not to be the case, which means that differences and explanations for the different paths of immigration and the social conditions linked to them need to be accounted for. One effect of these different positionings of migrants has been the rearrangement of the political community defined as legitimate welfare receivers. This case study does not allow for simple generalisations about the relation between migration, welfare state and biography, but throws light on the specific relation of migrants to the welfare state and the established life course regime and on the structural effects of migration on this regime. Further comparative research could discuss similarities and differences in other countries in order to build on a more general theory on the relation between migration, welfare and biography.

\section{Ethnic German immigration and changing welfare state positions}

Ethnic German (EG) immigration became a subject of general migration research following the collapse of the socialist countries and increased immigration of EGs to Germany since the late 1980s. EGs have been immigrating to Germany continuously since the Second World War, but until the late 1980s they were mainly the subjects of historical studies or social policy-oriented research on social integration (Bade 1987), the reasons for which are assessed later.

We commence from the observation that the structural position of EGs in the German welfare state has changed dramatically since 1990. They have been the targets of major expenditure reductions and lost many of their former social entitlements. The extent of these reductions will not be 
the focus here, rather the shift of the structural position of EGs in the welfare system linked to these reductions will be examined. In order to understand this shift it is important to clarify the position of EGs in the German welfare state before 1989. This category does not include refugees and expellees who came to West Germany after 1945, but does include the immigration of Germans from Poland, the Soviet Union, Hungary and Rumania after 1950, legally defined as EGs (see Table 2.1 and Figure 2.1). This group is then divided into those who came before and those who came after 1988.

The post-Second World War immigration of expelled persons, refugees and EGs in Germany was a result of highly conflictual state building processes in central and eastern Europe since the nineteenth century. The attempt of Germans since 1945 to migrate ${ }^{8}$ from eastern European countries to Germany resulted from enduring internal national conflicts in their countries of origin and from sovereignty claims by the German state which, since the end of the nineteenth century, regarded them as part of the German nation. The end of the Second World War, the resultant division of Germany, and the forced migration of refugees and expellees formed the peak of these nationality and state building conflicts (Lemberg 1950). The post-1988 immigration of EGs is a late outcome of this historical constellation.

The reinvention of citizenship in West Germany based on the principle of ius sanguinis ('blood' descent) was a reaction to the post-war situation. West Germany as one part of the diminished and divided former Germany claimed to be the only legal and legitimate successor of the former German Reich. The new German state's introduction of citizenship based on the ius sanguinis principle and the category of the German Volkszugehörigkeit ('belonging to the people') happened in order to maintain access to citizenship for German refugees from East European countries. The country was diminished and divided, and a large part of the population of the former state was living outside the territory of both German states. In the immediate post-war context, politically there existed no real alternative to the principle of ius sanguinis.

EGs were defined as German Volkszugehörige ('members of the people') affected by 'a fate of expulsion' (Vertreibungsschicksal) as a consequence of the Third Reich and the war. The 'Law on the Affairs of Expellees and Refugees' (the so-called 'Federal Expellee Law') in 1953 and the subsequent 'Federal Law for the Regulation of State Membership Questions' in 1955 (Heinelt and Lohmann 1992: 55ff.) included EGs into the category of Volkszugehörige even if they lived in countries like the Soviet Union, Yugoslavia or Rumania, i.e. outside the borders of the territory of the German state in 1937. ${ }^{9}$ In this way access to German citizenship for the EGs was secured. 
Table 2.1 Immigration of ethnic Germans 1950-88

\begin{tabular}{|c|c|c|c|c|}
\hline \multirow[t]{2}{*}{ Year } & \multirow[t]{2}{*}{ Total numbers } & \multicolumn{3}{|c|}{ Main countries of origin } \\
\hline & & Poland & Rumania & Soviet Union \\
\hline 1950 & 47,165 & 31,761 & 13 & - \\
\hline 1951 & 21,067 & 10,791 & 1,031 & 1,721 \\
\hline 1952 & 5,537 & 194 & 26 & 63 \\
\hline 1953 & 8,296 & 147 & 15 & - \\
\hline 1954 & 10,390 & 662 & 8 & 18 \\
\hline 1955 & 13,202 & 860 & 44 & 154 \\
\hline 1956 & 25,302 & 15,674 & 176 & 1,016 \\
\hline 1957 & 107,690 & 98,290 & 384 & 923 \\
\hline 1958 & 129,660 & 117,550 & 1,383 & 4,122 \\
\hline 1959 & 27,136 & 16,252 & 374 & 5,563 \\
\hline 1960 & 18,171 & 7,739 & 2,124 & 3,272 \\
\hline 1961 & 16,414 & 9,303 & 3,303 & 345 \\
\hline 1962 & 15,733 & 9,657 & 1,675 & 894 \\
\hline 1963 & 14,869 & 9,522 & 1,321 & 209 \\
\hline 1964 & 20,099 & 13,611 & 818 & 234 \\
\hline 1965 & 23,867 & 14,644 & 2,715 & 366 \\
\hline 1966 & 27,813 & 17,315 & 609 & 1,245 \\
\hline 1967 & 26,227 & 10,856 & 440 & 1,092 \\
\hline 1968 & 23,201 & 8,435 & 614 & 598 \\
\hline 1969 & 29,873 & 9,536 & 2,675 & 316 \\
\hline 1970 & 18,590 & 5,624 & 6,519 & 342 \\
\hline 1971 & 33,272 & 25,241 & 2,848 & 1,145 \\
\hline 1972 & 23,580 & 13,476 & 4,374 & 3,426 \\
\hline 1973 & 22,732 & 8,902 & 7,577 & 4,494 \\
\hline 1974 & 24,315 & 7,825 & 8,484 & 6,541 \\
\hline 1975 & 19,327 & 7,040 & 5,077 & 5,985 \\
\hline 1976 & 44,248 & 29,366 & 3,764 & 9,704 \\
\hline 1977 & 54,169 & 32,861 & 10,989 & 9,274 \\
\hline 1978 & 58,062 & 36,102 & 12,120 & 8,455 \\
\hline 1979 & 54,802 & 36,274 & 7,226 & 9,663 \\
\hline 1980 & 51,984 & 26,637 & 15,767 & 6,954 \\
\hline 1981 & 69,336 & 50,983 & 12,031 & 3,773 \\
\hline 1982 & 47,993 & 30,355 & 12,972 & 2,071 \\
\hline 1983 & 37,844 & 19,122 & 15,501 & 1,447 \\
\hline 1984 & 36,387 & 17,455 & 16,553 & 913 \\
\hline 1985 & 38,905 & 22,075 & 14,924 & 460 \\
\hline 1986 & 42,729 & 27,188 & 13,130 & 753 \\
\hline 1987 & 78,488 & 48,419 & 13,990 & 14,488 \\
\hline 1988 & 202,673 & 140,226 & 12,902 & 47,572 \\
\hline
\end{tabular}

Source: Bundesausgleichsamt Registrierverfahren (Federal Office for Social Compensation, Procedure of Registration 3/1989); quoted in Blaschke 1989: 238; Reichling 1995: $41 \mathrm{ff}$. 
Figure 2.1 Immigration of refugees and expellees (Flüchtlinge) from East European countries and refugees from the former GDR (Übersiedler) 1946-1960

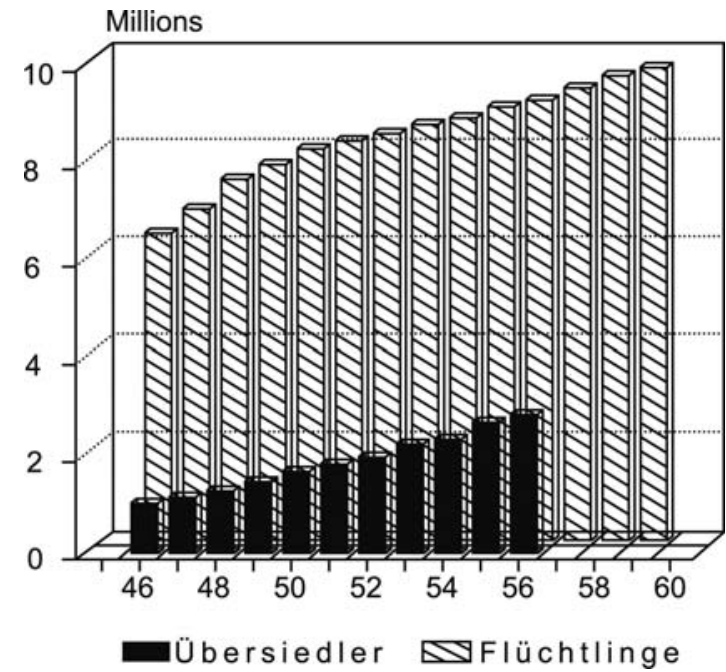

The granting of citizenship to EGs was a political reaction to the outcomes of the Second World War when, in reaction to the nationalist war politics of the German state, Germans living in East European countries were subject to all kinds of discrimination. This was especially the case in the Soviet Union, where many EGs were deported to the eastern parts of the country. The inclusion of EGs in the national refugee policy of the 1950s was, therefore, viewed publicly as an act of national solidarity with those who had to suffer from the disastrous politics of the German state. The laws of 1953 and 1955 granted access not only to citizenship for these groups but also to a range of social rights, services and supports which had been set up as part of the so-called 'compensation for burden' suffered by refugees, expellees and EGs alike. In the early 1950s, when the devastating effects of the war were still present and unemployment was high, the 'compensation for burden' was politically legitimised as an act of national burden-sharing and solidarity. The inclusion of EGs was seen as part of this act.

Between 1950 and 1988 around 1.6 million EGs immigrated to West Germany. During this period the numbers of immigrants varied between around 20,000 and 40,000 per year, with the exceptions of 1957/58 and 1977-1982 when numbers were considerably higher (see Table 2.1). These relatively low numbers of immigrants were the effect of the Cold War and the denial of freedom of movement for individuals in the socialist countries. But this is only half the story. The immigration of EGs became 
possible only as a result of political bargaining processes between states principally dissenting about the national belonging of certain parts of the population. Countries like Poland, Rumania or the Soviet Union never acknowledged any right of the EGs to live in Germany. They allowed the emigration of EGs depending on their political interests in improving bilateral relations or receiving economic support. Until 1989 Germany was an incomplete nation state ${ }^{10}$ and was engaged in these kinds of negotiations and conflicts about the legitimacy of competing sovereignty claims over parts of state populations. These kinds of political dissent are once again observable between numerous eastern European states (Brubaker 1994).

The rapidly growing number of EGs immigrating to Germany since 1987 was both part of and an indicator of a major change of social context in which this type of migration was situated. The collapse of socialist regimes eroded the former constellation of dissent about national belonging between Germany and eastern European states. The establishment of freedom of movement in eastern Europe allowed EGs to leave their countries if they wished to do so. 'Belonging to the German people' became a privileged option of migration in the countries of origin. The entitlement to enter the German state territory and to claim citizenship was widely used and soon met with immigration restrictions introduced by the German state.

The so-called 'social integration' of EGs in the period of the post-war history until the end of the 1980s was politically and socially a big success which (only seemingly paradoxically) made the EGs socially invisible as an immigration group. After the war until the end of the $1950 \mathrm{~s}$, research was politically funded and conducted to monitor the ways in which refugees and expellees were socially included, and the potential for conflict with the indigenous population (see Lemberg and Edding 1959). In the context of the 'economic miracle' (Wirtschaftswunder) of the 1950s these fears proved to be wrong. Refugees and EGs lost their political and scientific attraction as a major research topic. Subsequent migration research in Germany since the 1960s concentrated on labour migration, and few studies on EGs were conducted. The main result of these studies on social integration was that EGs were successful in terms of education, income, employment and property and that they did not differ significantly from the indigenous population in socio-structural terms. ${ }^{11}$ This success is best summarised in the observation that until the end of the 1980s no 'second generation' of EGs appeared socially in Germany. By the beginning of the 1980s, immigration of EGs was viewed as a politically manageable process (Zurhausen 1983). This was in stark contrast to the intensive public debates about settlement by labour migrant families, their possibly restricted capacity for 'social integration', and the political invention of the 'problem of the Turks' (Thränhardt 1988).

For an interpretation of this result, a closer look at the welfare programmes for EGs established in the 1950s and, with certain modifications, 
valid until the end of the 1980s is illuminating. The central structural provisions of these programmes entailed:

- An unemployment insurance system that included the EGs immediately after their immigration as though they had spent their whole former working life in Germany. An EG claiming to be a skilled worker was, for example, entitled to receive the amount of financial support equivalent to an unemployed indigenous skilled worker. Parallel occupational integration programmes then secured the (re-)adaptation of skills of these immigrants.

- The inclusion of EGs in the pension schemes as if they had contributed to these funds during their working lives.

- Direct access for EGs to health insurance systems.

- Added to these inclusions into the general social insurance systems of the welfare state were: extended language training programmes, general educational programmes, specific compensatory educational programmes for pupils, increased grants for children in school and university, reduced taxes, preferential consideration of self-employed EGs for public contracts, public housing programmes for EGs, provision of the means for purchase of household equipment, compensation for lost property, cheap credit with low or zero interest rates. ${ }^{12}$

This overview makes the working principle of welfare for EGs and its mode of securing their chances of social participation visible. EGs who immigrated until the end of the 1980s were treated as if they had spent their whole life in Germany, i.e. as if they had accumulated biographically the chances of inclusion which made further social inclusions likely. The welfare state 'repaired' the deviating biographies of the EGs by simulating and ascribing the structurally required elements for social participation. The effect of the additional compensatory welfare programmes was the equipment of the immigrating EGs with attributes, capacities and material means which enabled them to fulfil competently the social roles open to them as a result of the biographies ascribed to them by the welfare state. The treatment of the EGs in this way corresponded to the principles and traditions of the conservative corporatist German welfare state, which aims at the maintenance of the standard of living of different social status groups. EGs were provided with the resources to participate in the way of life of the social status group they claimed to belong to.

I have argued that modern welfare states can be understood as an institutional arrangement of organisations trying among other things to avoid chain reactions of exclusion by establishing and accompanying the life course to provide the conditions for an ordered course of life. This life course regime then structures the lifelong relation between the state and the individual citizens. The structural fundament of this relation is the specific political form of inclusion: national citizenship. The result of the 
political and legal ascription of membership in the national community to the immigration category of EGs was that EG immigrants acquired the structural qualifications and properties for participation and membership in the various social realms and organisations. Equipped by the German state with the necessary elements of a biography and a life course attached to their self-descriptions, they could then be observed as competent persons. This involved both formal entitlements and the substantial sense of competencies and means for fulfilling the roles connected with these biographies. ${ }^{13}$ Since EGs were defined as members of the nation they were treated as if their relation with the state had existed for their whole life.

This description outlines the conditions of immigration for the EGs until the end of the 1980s, when the character of the immigration process of EGs changed rapidly. Following the collapse of the socialist countries, most of the political restrictions upon the freedom of movement were suspended. The effects were dramatic. Between 1988 and 1993 about 1.6 million EGs immigrated to Germany (see Table 2.2). The German state reacted promptly by introducing means of control that are well-known in immigration countries. In 1990, a legal procedure for the immigration of EGs was installed. EGs were no longer allowed to enter the state territory unrestricted and to claim their 'belonging to the German people' in Germany. They had to enter a formal procedure in their countries of origin in order to be accepted as Germans. Only after their official acceptance as Germans did they receive immigration permission. By the end of 1992, as part of the asylum compromise, the number of EGs allowed to enter the country was limited to 220,000 per year. A newly introduced legal status of Spätaussiedler ('late resettler') restricted access to those persons born before 1 January 1993 and who could prove that they either had been affected by measures of expulsion themselves or were descendants of such families. The family members of these 'late resettlers' were excluded from this status if they were not 'late

Table 2.2 Immigration of ethnic Germans 1988-95

\begin{tabular}{lrrrr}
\hline Year & Total numbers & \multicolumn{3}{c}{ Main countries of origin } \\
\cline { 3 - 5 } & & Poland & Rumania & Soviet Union \\
\hline 1988 & 202,645 & 140,226 & 12,902 & 47,572 \\
1989 & 377,036 & 250,340 & 23,387 & 98,134 \\
1990 & 397,073 & 133,872 & 111,150 & 147,950 \\
1991 & 221,924 & 40,129 & 32,178 & 147,320 \\
1992 & 230,565 & 17,742 & 16,146 & 195,576 \\
1993 & 218,888 & 5,431 & 5,811 & 207,347 \\
1994 & 222,591 & - & - & - \\
1995 & 217,898 & - & - & - \\
\hline
\end{tabular}

Source: Bundesausgleichsamt (Federal Office for Social Compensation 1993; quoted in Nuscheler 1995: 123); figures of 1994/95 in Info-Dienst Deutsche Aussiedler, No. 75, January 1996, p. 3. 
resettlers' themselves. Since then, a large number of them have immigrated as 'foreigners'. 14

This legal amendment indicates that the entrance of EGs had become politically perceived as immigration and that it was to be dealt with as such. Parallel to this legal shift in their status and immigration rights, the attendant welfare programmes for EGs, i.e. their social rights, were heavily reduced (Bommes 1996). The decisive changes were the exclusion of EGs from unemployment benefits, reduced responsibilities for the labour administration, and the cessation of a number of the compensatory welfare programmes. Step by step, entitlements were reduced. Since 1993, EGs have relied on public assistance paid by local governments if they cannot find a job. Language training programmes were heavily reduced. The professional qualifications of EGs were in many cases no longer regarded as equivalent to German job definitions. Simultaneously, the budgets for occupational training were drastically cut and, in many cases, local governments had to pay for them. The unbalanced distribution within Germany of immigrating EGs during the first half of the 1990s and their concentration in certain areas of Germany led to public complaints from a number of local governments about their exploding social budgets. In reaction to this the 1996 residence assignment law (Wohnortzuweisungsgesetz) reduced the freedom of movement of EGs' for three years after arrival in case they became dependent on public assistance. EGs are no longer allowed to reside in places of their choice but are tied to the place of residence assigned to them by the administration. ${ }^{15}$

\section{Ethnic Germans, labour migrants and changing relations between the state and community of welfare receivers}

In stark contrast to the situation between the 1960s and the 1980s, EGs have a high unemployment risk (Bommes 1996: 224; Thränhardt 1998: 34ff.). They have also become an immigrant group of major political and scientific concern. The political and scientific 'integration-discourse' has again taken notice of the EGs. Political and scientific observers have discovered the so-called second generation of EGs as a target group (e.g. Auernheimer 1995).

The empirical long-term development is difficult to assess, but this chapter's focus is on the potentially systematic effects of these recent developments on the relation between migration and the welfare state. An interesting starting point for a theoretical interpretation is the public 'silence' over the most relevant reductions of the welfare entitlements of EGs. These political decisions had been taken as part of general budget restrictions during the early 1990s. The public debates about these restrictions concentrated on the general topics concerning the amount of unemployment benefits 
and the conditions of reception. In comparison to these publicly intensive debates, the decisions affecting the EGs were taken rather silently in the neo-corporatist negotiation systems where bits and pieces for reduction were collected that were acceptable to the parties participating in the incremental mode of decision finding. The administrative details of these kinds of decisions were of no major public interest and the EGs themselves formed no relevant pressure group participating in the decision game.

In the 1950s, the inclusion of the EGs in welfare schemes had been viewed as a political requirement of national solidarity. EGs were seen as part of the nation and its 'fate', the catastrophe of the Second World War and its burdens had to be shared in a solidaristic manner by the whole nation. At the end of the 1980s, however, even in the context of the German unification process, national semantics of this type no longer possessed their former mobilising potential. The devalorisation of ethnic and national semantics in Germany during the 1970s and 1980s (Bommes 1995) provided the background against which the welfare rights of EGs could be reduced in the corporatist systems of the German welfare state without being publicly debated (Bommes 1996). The exclusion of immigrating EGs from core provisions of the welfare state mobilised almost no public concern about the legitimacy of treating German citizens in nearly the same way as foreign immigrants. Rather, this became an explicit demand within certain factions of the Social Democratic and the Green Party. EGs have become an immigrant group which, for historical reasons, possesses a right to citizenship and to enter the territory, but which at the same time is deprived of central welfare state provisions.

The meaning and relevance of this change can best be assessed by comparing the situation of the recent German immigrants with the conditions for labour migration of the 1960s and 1970s. The immigration of the Gastarbeiter was initiated as part of a labour-market policy of the national welfare state. As in other European countries, the state still acted like the sovereign supervisor of the national economy and its labour market (Scharpf 1996). Part of this supervision was the legal inclusion of migrants in the welfare regulations of the labour market. After some 30 years of employment in specific segments of the labour market, labour migrants had by the end of the 1990s accumulated social rights which guaranteed them a living standard on a low, but fairly secure level (Thränhardt, Dieregsweiler and Santel 1994; Seifert 1995). In this sense, the labour migration of the 1960s and 1970s and the subsequent settlement of the migrant families have been part of the immigration history of a successful national welfare state. Once their immigration proved to be irreversible, the political frame of reference became the 'integration paradigm'. Migrants were to be 'integrated into society' by means of the national welfare state and in the end to become 'its members'. 
Labour migrants differ from the pre-1990 EGs because welfare activities for labour migrants were mainly defined by their position in the labour market, i.e. as a structural outcome of the German welfare state structure centred around employment. The main differences between the EGs and the labour migrants become visible in view of, first, the fact that in sociostructural terms most of the labour migrants are part of the lower strata of Germany's social structure (Geißler 1996). The history of their immigration and its political preconditions seem to tie them to this position. They have not disappeared as a category in the general social structure like the EGs. Second, labour migrants were different from the EG migrants because they were not supported by a similar commitment by the educational and vocational system to the success of their children. Welfare programmes for EGs were targeted at all age groups and were committed to substitute for the missing lifelong relationship between the individual and the national welfare state. In contrast, a large number of the children of labour immigrants failed to reach educational levels that could open attractive career perspectives for them. Labour migrants are heavily under-represented in the dual vocational training system, and their fathers (and partly their mothers) have only, to a very limited degree, gained positions at their workplaces allowing them to open access to memberships in factories (Faist 1995). Unemployment among immigrant youth is therefore extremely high (Thränhardt 1998). The limited and 'retarded' commitment of the welfare state to labour migrants seems to affect mainly certain strands of their children.

Nevertheless, it remains true that the welfare state aimed at integrating the immigrants 'into society' and that missing that target was and is seen as a political failure. The national welfare state of the 1970s and 1980s had become responsible for the chances of labour immigrants to lead a decent life and to legitimately claim certain social rights and expectations. Violent attacks of right-wing political groups were, therefore, almost unilaterally rejected in German politics. By the end of the 1980s, the former national community of West Germany of the 1950s had changed into the community of legitimate welfare receivers which included the major part of Germany's substantial foreign population.

Against this background, immigrating EGs, even if their right to enter was seldom publicly denied after 1989, were no longer perceived as legitimate welfare receivers since they had not contributed to the GNP. After 1989, the federal government legitimised changed welfare programmes by arguing that there should be no privileges for EGs. What had been originally conceptualised as compensation for the forceful separation and exclusion from the national community came to be seen as an illegitimate advantage. In the changed context of the early 1990s, the new community of welfare receivers provided legitimacy for the welfare state to get rid of social responsibility for newly arriving immigrants. This legitimacy no longer 
relied on national rhetorics, but nevertheless affirmed the undissolvable basis of the welfare state: closure and the maintenance of a threshold of inequality.

\section{Conclusion}

Analysing the comparative positions of EGs and the former 'Gastarbeiter' in the German welfare state demonstrates how the ways that different immigrant groups are included in the life course regime of the welfare state have long-term effects for their socio-structural position and their chances of social inclusion. The labour migrants of the 1960s and 1970s were included in the structural provisions of the welfare state mediated by the political form of recruitment for the labour market. After thirty years they were able to accumulate a certain amount of entitlements and to develop slowly a career structure which allowed them to reach a living standard on a low, but fairly secure level. The EGs of the 1990s immigrated into Germany on the basis of their political status. Whether they manage to enter the labour market and the welfare provisions centred on employment remains to be seen given that their 'deviant' careers are no longer repaired by the welfare state through the substitute ascription of a complete biography.

Analysing the comparative position of labour migrants and EGs also allows us to view the reconstruction of the community of legitimate welfare receivers. In the 1950 s belonging to the nation still defined this community; by the end of the 1980s it was more or less composed of those who had contributed to the GNP. This includes the foreign population of the labour migrants and excludes to different degrees asylum seekers, refugees, contract labourers and EGs (even the East Germans in the view of a large part of West Germans). One can summarise this by saying that the welfare state redefines its addressee in relation to its technical purposes. To do this it substitutes the national frame of reference by the criteria of legal residence and participation in the labour market. In the case of Germany, this becomes visible in the changing welfare positions of German and foreign immigrants.

Since 1989, migration policies in Germany have been generally characterised by the effort to strictly limit the right of access to and settlement in the state territory for newly arriving migrants. The state seeks to allow only time-limited and reversible labour immigration under severely restricted conditions, for example, contract labour. It also seeks to reduce welfare provisions for those who are in a legal position to acquire permanent residence permits. For these migrants, including the EGs, the welfare state accepts only restricted responsibility. It provides the means of subsistence, but to a much lesser extent, the social conditions of beginning a career, 
entering a structured life course and accumulating elements for an accountable biography. Further research will have to clarify if immigration after 1989 can also be interpreted as part of a general 'de-institutionalisation of the life course'.

Does the case of the EGs merely reflect a specificity of Germany with no relevance for other countries with differently organised welfare states? The case not only makes visible the specific mode in which the close relation between national welfare states and their citizens has been structured through the institutionalisation of a life course regime, but also throws light on the erosion of this arrangement through immigration. The relevance of the case needs further clarification through comparative research that analyses the position of different immigrant groups in the life course regimes of the different types of welfare states. This will provide the basis for a more solid answer to the question of if, and in what sense, different forms of immigration in Europe may be part of a general de-institutionalisation of the life course. That is, a process which erodes the historically established arrangement by which the welfare state took over the responsibility in relation to its citizens for the assurance that a structured life course linked with biographical expectations and prospects could be realised. One result of the restrictions of sovereignty of the national welfare states by socalled globalisation is the evolution of more groups who can no longer rely on the welfare state as an institutionalised safeguard of the social preconditions for an ordered and expectable life course. Migrants are likely to be among these groups.

\section{Notes}

I 'This is why 'identity' and 'self-realisation' become a problem [...] one cannot know who one is but has to find out if one's own projections do find social acceptance" (Luhmann 1997: 627).

2 Residualistic welfare states perceive the safeguard of transferabilities only in a limited sense as a political duty. The 'conservative' type of welfare states however aims at the maintenance of the standard of living, whereas the 'social democratic' type is based on the concept of 'social citizenship' as interpreted by Marshall (see EspingAnderson 1990).

3 This 'interplay' would need more sociological specification concerning the different forms of power created by organisations and the political system which cannot be done in this paper. Organisations gain power based on positive sanctions, since they offer income for labour to individuals who depend on this payment because of their 'risk of unprovidedness' (Weber I972); the power of states is based on negative sanctions, on the monopolisation of the means of physical violence, the ultimate foundation of their capacity to produce collectively binding decisions (Easton I968). The relation between states and organisations circumscribes a field of tension between the indispensable organisational power, on the one hand resulting from the form of membership, and the state power on the other hand relying on this modern form of 
organisation itself but intervening for welfare reasons in organisational power by modifying preconditions and consequences of organisational decision processes.

4 Marx's argument about the commodification of the labour power was precisely an argument about social abstraction.

5 If inclusion cannot be secured, welfare states create secondary orders of exclusion by providing scripts of failure (defined for instance by the rules of insurances) and organisations, e.g. of social work which deal with the social accountability of exclusions (Bommes and Scherr 1996).

6 It remains the central insight of Marshall (I950) that the form 'citizenship' establishes the expectation as legitimate that politics has to further and increase the chances of inclusion of their citizens.

7 Most pension insurance funds in European welfare states make entitlements dependent on the time period spent on state territory and/or the time period of employment and contribution (Dörr and Faist 1997). This demonstrates the life course oriented relation between the welfare state and its citizens.

8 The immigration of EG is politically defined as 'remigration', 'an effort of Germans to come home'.

9 The constitution of 1949 defined those as Germans who belonged to the German people and lived inside these borders of I937. The main difference between refugees, expellees and EG, the 'Aussiedler', exists between their places of origin: refugees and expellees were defined by their 'belonging to the people' and their place of origin laying inside the borders of Germany on 3I December I937; EGs were assumed to be German and to be affected by measures of expulsion because of their 'belonging to the German people'.

Io I989, the subsequent unification process and the treaties with various countries established for the first time the identity of territory and population which the German state claims sovereignty about.

II See Bade (1987), Lüttinger (1986,1989) and for a summary of the results of this research see Bommes, Castles and Wihtol de Wenden et al. (I999: 78f.).

I2 This is an incomplete list. For a more detailed overview see Otto (I990) and Bommes and Rotthoff (I994).

I3 Looking at education it made a striking difference that the assumption of the individual ability to learn and to participate in education was the basis for the decision to put the children of EGs through the equivalent school level they had been visiting in their countries of origin. The presupposition of competence was backed up by additional education. In contrast, the starting assumption for the education of Turkish pupils was the expectation of major social problems and minor cultural and cognitive abilities to assimilate (e.g. Schrader, Nikles and Griese 1976). As one EG put it in an interview: 'I came here as a pupil I2 years old and spoke no German. They put me in a gymnasium, taught me German and then I made the Abitur. I can't speak Polish anymore.' The ascription of cultural belonging or difference and the expectations of success or failure obviously define in a crucial manner the starting social conditions for individual chances to accumulate the required elements of a successful social career.

I4 This change can be seen as part of the readjustment of the German concept of citizenship. In 1990, I993 and I999 amendments of the foreigner and citizenship laws had installed legal access for labour migrants and their children to German citizenship. The restrictions of the legal status of EG can be interpreted as part of the strengthening of territoriality as a criterion for the granting of citizenship and of the weakening of the ius sanguinis tradition. This is another indicator that this tradition is best understood against the historical background of the German state building process ending in 1989 . 
I5 It appears ironic that the immigration of members of the 'national community' provides the occasion for reintroducing elements of the traditional 'Heimatrecht' ('home law') of local governments. This traditional law was abandoned by the Prussian state in I842 in order to undercut the local governments' refusal of immigrants whom they suspected of being ill equipped to care for themselves and to rely on poor relief. The abolition of the 'Heimatrecht' and the introduction of a poor relief system through the central state can be regarded as one major step of the development of the modern welfare state (Reidegeld I998; Halfmann and Bommes 1998). It is certainly not exaggerated to regard the introduction of the residence assignment law in 1996 as symptomatic for the structural effects of migration on the welfare state.

\section{References}

Auernheimer, G. (1995), Einführung in die interkulturelle Erziehung. Darmstadt: Wissenschaftliche Buchgesellschaft.

Bade, K.J. (1987), 'Sozialhistorische Migrationsforschung und "Flüchtlingsintegration" , in R. Schulze, D. von der Brelie-Lewien \& H. Grebing (eds), Flüchtlinge und Vertriebene in der westdeutchen Nachkriegsgeschichte. Bilanzierung der Forschung und Perspektiven für die künftige Forschungsarbeit. Hildesheim: Lax Verlag.

Blaschke, D. (1989), 'Aussiedler - Eine Problemskizze aus der Sicht der Arbeitsmarkt- und Berufsforschung', Arbeit und Sozialpolitik 43 (8/9): 238-245.

Bommes, M. (1995), 'Migration and Ethnicity in the National Welfare State', in M. Martiniello (ed.), Migration, Citizenship and National Identities in the European Union. Aldershot: Avebury.

Bommes, M. (1996), 'Migration, Nationalstaat und Wohlfahrtsstaat - kommunale Probleme in föderalen Systemen', in K.J. Bade (ed.), Migration - Ethnizität - Konflikt. Systemfragen und Fallstudien (IMIS-Schriften, vol. 1). Osnabrück: Universitätsverlag Rasch.

Bommes, M. (1999), Migration und nationaler Wohlfahrtsstaat. Ein differenzierungstheoretischer Entwurf. Opladen/Wiesbaden: Westdeutscher Verlag.

Bommes, M. \& U. Rotthoff (1994), 'Europäische Migrationsbewegungen im kommunalen Kontext', in Konrad-Adenauer-Stiftung (ed.), Interne Studien No. 100. St. Augustin: Konrad-Adenauer-Stiftung, pp. 93-148.

Bommes, M. \& A. Scherr (1996), 'Exklusionsvermeidung, Inklusionsvermittlung und/oder Exklusionsverwaltung. Zur gesellschaftstheoretischen Bestimmung sozialer Arbeit', Neue Praxis 26: 107-123.

Bommes, M., St. Castles \& C. Wihtol de Wenden (eds) (1999), 'Migration and Social Change in Australia, France and Germany' (IMIS-Beiträge 13). Osnabrück: Universitätsverlag Rasch.

Brubaker, R. (1994), 'Nationhood and the National Question in the Soviet Union and PostSoviet Euroasia: An Institutionalist Account', Theory and Society 23: 47-78.

Corsi, G. (1993), 'Die dunkle Seite der Karriere', in D. Baecker (ed.), Probleme der Form. Frankfurt am Main: Suhrkamp.

De Swaan, A. (1988), In Care of the State. Health Care, Education and Welfare in Europe and the USA in the Modern Era. Cambridge: Polity Press.

Dörr, S. \& Th. Faist (1997), 'Institutional Conditions for the Integration of Immigrants in Welfare States: A Comparison of the Literature on Germany, France, Great Britain, and the Netherlands'. European Journal of Political Research 31, 4: 401-426.

Easton, D. (1968), 'Political Science', in D.L. Sills (ed.), International Encyclopedia of the Social Sciences. New York/London: Macmillan.

Esping-Andersen, G. (1990), The Three Worlds of Welfare Capitalism. Princeton: Princeton University Press. 
Faist, Th. (1995), Social Citizenship for Whom? Young Turks in Germany and Mexican Americans in the United States. Aldershot: Avebury.

Fuchs, P. (1997), 'Weder Herd noch Heimstatt - Weder Fall noch Nichtfall. Doppelte Differenzierung im Mittelalter und in der Moderne', Soziale Systeme 3 (2): 413-437.

Geißler, R. (1996), Die Sozialstruktur Deutschlands. Opladen/Wiesbaden: Westdeutscher Verlag.

Grawert, R. (1984), 'Staatsangehörigkeit und Staatsbürgerschaft', Der Staat 23: 179-204.

Hahn, A. (1988), 'Biographie und Lebenslauf', in H.-G. Brose \& B. Hildenbrand (eds), Vom Ende des Individuums zur Individualität ohne Ende. Opladen: Leske und Budrich.

Halfmann, J. \& M. Bommes (1998), 'Staatsbürgerschaft, Inklusionsvermittlung und Migration. Zum Souveränitätsverlust des Wohlfahrtsstaates', in M. Bommes \& J. Halfmann (eds), Migration in nationalen Wohlfahrtsstaaten. Theoretische und vergleichende Untersuchungen (IMIS-Schriften, vol. Ø). Osnabrück: Universitätsverlag Rasch.

Heinelt, H. \& A. Lohmann (1992), Immigranten im Wohlfahrtsstaat am Beispiel der Rechtspositionen und Lebensverhältnisse von Aussiedlern. Opladen: Leske und Budrich.

Kohli, M. (1985), 'Die Institutionalisierung des Lebenslaufs', Kölner Zeitschrift für Soziologie und Sozialpsychologie (KZSS) 37 (1): 1-29.

Kohli, M. (1986), 'Gesellschaftszeit und Lebenszeit. Der Lebenslauf im Strukturwandel der Moderne', in J. Berger (ed.), Die Moderne: Kontinuitäten und Zäsuren. Soziale Welt (Special Issue 4). Göttingen: Schwartz.

Lemberg, E. (1950), Geschichte des Nationalismus in Europa. Stuttgart: Curt E. Schwab.

Lemberg, E. \& F. Edding (eds) (1959), Die Vertriebenen in Westdeutschland. Ihre Eingliederung und ihr Einfluß auf Gesellschaft, Wirtschaft, Politik und Geistesleben, 3 vols. Kiel: Hirt-Verlag.

Luhmann, Niklas (1989), 'Individuum, Individualität, Individualismus', in idem, Gesellschaftsstruktur und Semantik. Studien zur Wissenssoziologie der modernen Gesellschaft 3. Frankfurt am Main: Suhrkamp, pp. 149-258.

Luhmann, N. (1995), 'Inklusion und Exklusion', in N. Luhmann, Soziologische Aufklärung, vol. 6, Opladen: Westdeutscher Verlag.

Luhmann, N. (1997), Die Gesellschaft der Gesellschaft, 2 vols. Frankfurt am Main: Suhrkamp.

Lüttinger, P. (1986), 'Der Mythos der schnellen Integration. Eine empirische Untersuchung zur Integration der Vertriebenen und Flüchtlinge in der Bundesrepublik Deutschland bis 1971', Zeitschrift für Soziologie 15 (1): 20-36.

Lüttinger, P. (1989), Integration der Vertriebenen. Eine empirische Analyse. Frankfurt am Main/New York: Campus.

Marshall, T.H. (1950), Citizenship and Social Class and Other Essays. Cambridge: Cambridge University Press.

Miles, R. \& D. Thränhardt (eds) (1995), Migration and European Integration: The Dynamics of Inclusion and Exclusion, London: Pinter.

Nuscheler, F. (1995), Internationale Migration. Flucht und Asyl. Opladen: Leske und Budrich.

Otto, K.A. (1990), 'Aussiedler und Ausiedlerpolitik im Spannungsfeld von Menschenrechten und Kaltem Krieg. Historische, politisch-moralische und rechtliche Aspekte der Aussiedlerpolitik', in K.A. Otto (ed.), Westwärts - Heimwärts. Aussiedlerpolitik zwischen 'Deutschtümelei' und Verfassungsauftrag. Bielefeld: AJZ-Verlag.

Pierson, P. (1993), 'When Effect becomes Cause: Policy Feedback and Political Change', World Politics, 45: 595-628.

Pierson, P. (1995), 'The New Politics of the Welfare State', ZeS-Working Papers, Zentrum für Sozialpolitik, Bremen: University of Bremen.

Reichling, G. (1995), Die Deutschen Vertriebenen in Zahlen. Teil 1: Umsiedler, Verschleppte, Vertriebene, Aussiedler 1940-1985. Bonn: Kulturstiftung der Deutschen Vertriebenen. 
Reidegeld, E. (1998), 'Armenpflege und Migration von der Grundung des Deutschen Bundes bis zum Erlaß des Gesetzes über den Unterstützungswohnsitz', in M. Bommes \& J. Halfmann (eds), Migration in nationalen Wohlfahrtsstaaten. Theoretische und vergleichende Untersuchungen (IMIS-Schriften, vol. 6). Osnabrück: Universitätsverlag Rasch.

Scharpf, F.W. (1996), 'Negative and Positive Integration in the Political Economy of European Welfare States', in G. Marks, F. Scharpf, P. Schmitter \& W. Streeck (eds), Governance in the European Union. London: Sage.

Schrader, A., B.W. Nikles \& H.M. Griese (1976), Die zweite Generation. Sozialisation und Akkulturation Ausländischer Kinder in der Bundesrepublik. Kronberg: Athenaeum.

Seifert, W. (1995), Die Mobilität der Migranten. Die Berufliche, Ökonomische und Soziale Stellung Ausländischer Arbeitnehmer in der Bundesrepublik. Berlin: Edition Sigma.

Stichweh, R. (1998), 'Migration, nationale Wohlfahrtsstaaten und die Entstehung der Weltgesellschaft', in M. Bommes \& J. Halfmann (eds), Migration in nationalen Wohlfahrtsstaaten. Theoretische und vergleichende Untersuchungen (IMIS-Schriften, vol. 6). Osnabrück: Universitätsverlag Rasch.

Strauss, A. (1959), Mirrors and Masks: The Search for Identity. New Brunswick: Transaction Publishers.

Thränhardt, D. (1988), 'Die Bundesrepublik Deutschland - Ein unerklärtes Einwanderungsland', Aus Politik und Zeitgeschichte, 24: 3-13.

Thränhardt, D. (1998), Regionale Ansätze und Schwerpunktaufgaben der Integration von Migrantinnen und Migranten in Nordrhein-Westfalen. Studie im Auftrag des Ministeriums für Umwelt, Raumordnung und Landwirtschaft des Landes Nordrhein-Westfalen. Institut für Politikwissenschaft, Münster: University of Münster.

Thränhardt, D., R. Dieregsweiler \& B. Santel (1994), 'Landessozialbericht' (vol. 6), Ausländerinnen und Ausländer in Nordrhein-Westfalen, Düsseldorf: Ministerium für Arbeit, Gesundheit und Soziales des Landes Nordrhein-Westfalen.

Weber, M. (1972), Wirtschaft und Gesellschaft, $5^{\text {th }}$ edition. Tübingen: Mohr.

Zurhausen, G. (1983), 'Aufgabe und Verantwortung von Bund, Ländern und Gemeinden für die Aufnahme und Eingliederung der Aussiedler', in H. Harmsen (ed.), Die Aussiedler in der Bundesrepublik Deutschland, Forschungen der WAR Deutsche Sektion. 2. Ergebnisbericht. Anpassung, Umstellung, Eingliederung. Vienna: Braumüller. 


\section{Systems theory and the 'ethnic inequality' of migrant workers}

First published in 2004 by Humanities Online as the chapter 'Zur Bildung von Verteilungsordnungen in der funktional differenzierten Gesellschaft: Erläutert am Beispiel "ethnischer Ungleichheit" von Arbeitsmigranten' (pages 399-428) in Differenzierung und soziale Ungleichheit: Die zwei Soziologien und ihre Verknüpfung, edited by Thomas Schwinn

Reprinted in 2011 in 'Migration und Migrationsforschung in der modernen Gesellschaft' in IMIS-Beiträge 38 (pages 69-96)

Translation into English for this book by Anja Löbert

\section{Introduction}

Differentiated subdisciplines of sociology mediate their relationship to general sociological problems of theory and problems of social theory in terms of the preservation of their own core issues. This is the case for the sociology of the family, industrial sociology, the sociology of social conflicts, the sociology of migration, and also for the sociology of social inequality and the associated analysis of social structure. The sociology of social inequality, previously the sociology of class and stratification, has always, in its more sophisticated variants, claimed a central position for the description of modern society and the theoretical understanding thereof. A major role is played here by attempts at explaining inequality with a traditional, social-theory orientation. In keeping with this, there is a tendency to avoid theoretical traditions which do not accord the issue of social inequality a sufficiently central position, in the sense of considering social inequality the immediately obvious starting point for the development of sociological theory. The individualization debate in the 1980s, however, has eroded the claims of inequality studies. One of its results was the gradual disintegration of a theoretical concept of inequality. The procedures for measuring inequality, increasingly elaborate in their methodology, reflected the diversification of inequalities and the extent to which the observation and description thereof depended on context. 
Given this background, anyone wishing to bring sociological systems theory - of all theories - into play must demonstrate plausibly that issues in inequality studies can be adequately dealt with even when inequality no longer forms the immediate starting point for the development of sociological theory. It is possible, with certain modifications, to make Luhmann's theory of functional differentiation productive for the analysis of social relations of distribution and corresponding semantics of inequality. This theory shows that modern society has a problem of distribution and equality, precisely because there is no structural provision for solutions to this within its primary form of differentiation. In terms of functional differentiation, questions of distribution and inequality constitute secondary issues which nonetheless require resolution. These solutions are not, however, generated in the individual function systems, but in organizations. This will be shown in the first part (sections 2 and 3). The aim is to demonstrate that the connection between distribution, inequality and the structures of inclusion and exclusion in modern society can be understood as the result of the interplay of organizations in the various function systems and the modern welfare state. This interplay gives rise to organizationally and semantically elaborated orders of distribution and of inclusion and exclusion. A key advantage of systems theory here is that it has, within the frame of reference of its theory of modern society, at the same time elaborated a theory of organization, and that the conceptual significance of this theory has, I believe, hardly been used for inequality studies so far. The second part (section 4) aims to demonstrate, using as an example the ethnic inequality which has formed in the wake of labour migration in Germany, that this form of inequality can be understood well within the framework of inequality studies if this discipline is conceived in the manner proposed. ${ }^{1}$

\section{Functional differentiation and the problem of the distribution of social resources}

What can inequality studies gain for its core issues by making greater reference to the theory of functional differentiation, as formulated in sociological systems theory, particularly by Luhmann? In order to answer this it is necessary to admit the possibility that the issue of inequality in modern society can be appropriately understood even if one does not see inequality as a primary or the primary issue in sociology - as did Kreckel (1992) or, before him, Dahrendorf - and if one does not consider it as the starting point for the development of theory.

From the point of view of differentiation theory, it can be shown that equality gains a central significance in modern society because of the specific structure of the inclusion of individuals in social systems. ${ }^{2}$ The 'double freedom' and equality of individuals, already seen by Marx - in his 
terms the prerequisite for their utilization as the commodity 'labour' in labour markets - denotes a general structural prerequisite for the utilization of individuals by the function systems of modern society. The favourably viewed 'freedom of the individual' stands for the freedom from prior commitments, and for the possibility, willingness, and capability of individuals to take advantage of specific opportunities to participate in social systems. 'Equality' overrules particularistic access restrictions; the conditions for inclusion are theoretically the same for everyone. In the function systems and organizations of modern society, inclusions come about in the terms valid there; the freedom and equality of individuals release them from the necessity of taking into account prior commitments. The condition for individuals' participation in society is therefore their detachment, their exclusion as whole entities (Luhmann 1989).

This formal equality, which constitutes a social prerequisite for individuals' participation in modern society, has as yet little to do with the core issue of inequality research. The modern demand for more substantial social equality of individuals in relation to fundamental opportunities for participation and opportunities in life has its structural anchoring point in the political form of organization which is the nation state, and in the associated form of inclusion, citizenship. Historically and structurally, belonging to the nation as a citizen is the basis for the claim to substantial equality, as Marshall (1992 [1950]) already observed. This particular form of inclusion is itself based on the particular form of differentiation of politics, its segmentary internal differentiation into nation states (Bommes 1999). The social semantics of equality as a form of observation and evaluation of the distribution of resources has its structural foundations here.

The distinction between equality/inequality as a social semantics of the observation and evaluation of distribution and also of distribution itself also makes visible the fact that problems of distribution become problematic in modern society because there is no longer - and cannot be - a solution to this which is systematically anchored in society's primary form of differentiation, functional differentiation.

Modes of inclusion and exclusion in social systems are, depending on the type of society, more or less closely linked with structures of distribution of social resources. Thus, for example, income poverty in present-day society is in many cases a consequence of unemployment, i.e. of unsuccessful inclusion in positions which provide an income. Questions of inclusion and exclusion are not, however, to be equated with questions of distribution. Distributions are not automatically regulated along with the utilization of individuals. Taking up duties as a doctor, nurse, engineer, scholar, caretaker, tennis pro or social worker does not necessarily determine, in functional terms, at what level salaries, prestige and social recognition should be set, and how the financial and social resources of organizations should therefore be distributed. ${ }^{3}$ The emergence and consolidation of 
income distributions are not regulated by the structure of functional differentiation. It is characteristic of the form of differentiation of modern society that questions of inclusion/exclusion and of the distribution of benefits systematically move apart. Its relations of distribution, and the fact that the obvious discrepancies in distribution can no longer be justified in the frame of reference of an estate-based order of inclusion, thus also first become reflexive in the concept of class, which treats these discrepancies as a scandal against the background of a generalized claim to equality (Luhmann 1985).

Modern society knows no comprehensive rule, structurally anchored in its form of differentiation, for questions of distribution. The inclusion of individuals occurs in the respective function systems and the organizations associated with them, in each case in line with their requirements for communication. When it comes to participation in the law, politics, education, family, academia and even the economy, the primary issue is not problems of distribution, but the mobilization of individuals for the function-specific communications required in each case and the securing of their continuability. Individuals are needed for the dispensation of justice, the production of political decisions, the making of investments or the development of theories. The processes of justice, education, investment or political decision-making mean that, even in cases where distribution is an immediate concern, the distributions of education and training, income, political influence, scholarly reputation and healthcare must be dealt with under the premises of individual function systems as a prerequisite from which legal decisions, educational measures or political decisions can only follow on. One can try, using political means, to improve the labour market prospects of disadvantaged young people through occupational support measures, but one cannot grant them the relevant qualifications by political means. One can try by means of education to increase the future chances of children from low-income families, but one cannot - in this context - supply them directly with money. The law can enjoin the welfare state, on the basis of social security law, to pay higher benefits to needy individuals. But it can neither intervene directly in economic relations of distribution nor pass laws determining welfare-state benefits.

In conditions of functional differentiation, there can be no comprehensive regulation of distribution for the multitude of inclusions and exclusions, and therefore also no regulation which can be anchored structurally in the primary form of differentiation itself. This would override the functional form of differentiation itself. In modern society, problems of distribution and social inequality thus have their basis in the fact that, on the one hand, society has no general solution for these problems and that, on the other hand, solutions for distributions obviously do nonetheless repeatedly arise and become established and lead to phenomena of stratification and of social registration of structured inequality, which are then 
thematized in inequality studies. Such more or less stable solutions cannot be understood as the direct result of the primary structural characteristics of modern society, of its form of differentiation. Nonetheless, secondary structural formations of distribution, i.e. the structured inequality identified by inequality studies, occur in the function systems and organizations. They are secondary because such structural formations are not already logically inherent in the primary structure of differentiation, but develop within its frame of reference. ${ }^{4}$

\section{On the production of secondary orders of distribution and social inequality by organizations and welfare states}

In modern society the conditions and opportunities for inclusion and exclusion in the function systems and regulation of distributions are largely mediated and related to each other by organizations. Function systems are fundamentally open for the inclusion of all individuals as persons within the function-specific terms which define these systems: structurally - and also normatively, as a value - universalism of inclusion applies. As citizens, legal persons, buyers or sellers, students, patients or viewers, everyone is supposed to have access to politics, the law, the economy, education, sport or the mass media, as long as they fulfil the system-specific conditions. But this does not guarantee participation, it merely states that this is possible in principle. Socially, many prerequisites must be fulfilled before the universalism of inclusion of the function systems can become reality, and the difficulties of empirical implementation require the welfare state to act as a political mediator of the relations of inclusion in modern society (Bommes 1999). It focuses, for reasons which will be explained below, on organizations, and takes their modes of inclusion as the basis for mediating individuals' social opportunities for participation.

Organizations utilize individuals for formal membership roles and specify in this form the conditions for entry and exit (Luhmann 1964: 39ff.). They are able to utilize people in this way because the assumption of service roles in organizations is the prerequisite for individuals to receive an income. The required willingness to work includes them in the economy and thus provides organizations with a medium of inclusion, work, for the successful utilization of individuals for ever more improbable, highly specified service roles in organizations (cf. Bommes \& Tacke 2001). The welfare state follows on from this cumulative relationship between the economy and organizations in which the available incomes are distributed. The connection between distribution, inequality and the structures of inclusion and exclusion can therefore be reconstructed, in the affluent regions of the world society, as the result of the interplay of organizations in function systems and modern welfare states - as will be demonstrated below. 
It is obvious where in modern society the distributions which are significant for the lifestyle of individuals are carried out: conditions and opportunities for inclusion and exclusion in function systems and the regulation of distributions are primarily mediated and related to each other by organizations. ${ }^{5}$ Organizations are social systems which regulate the participation of individuals in specific manners which have consequences for their chances of inclusion elsewhere. On the one hand, they utilize individuals as members for service roles. For this they specify the conditions for entry and exit, for example as an assembly-line worker, a fitter, an accountant, a business economist, doctor, academic assistant, doorman or personnel manager. The form of such membership roles in organizations and the associated expectations for their competent fulfilment constitute the prerequisites for inclusion in service roles to which the majority of people in modern society must gain access in order to receive an income. On the other hand, organizations include individuals in service-receiving roles, e.g. as audience, customers, patients, clients or students, and they thus offer access to the services of the function systems of politics, the economy, the law, health or education. Organizations thus doubly mediate the conditions and opportunities for inclusion and exclusion in function systems.

Organizations include persons in formal membership roles (or exclude them) in terms of the procurement of resources and the creation of solutions to problems. They admit persons into positions in terms of their expectable current and future aptitude or competence. They generally detect this aptitude and competence from individuals' life course and career. The prerequisite for this form of observation of individuals is that the parallelization between form of differentiation and form of inclusion has disintegrated. With the transition from stratificatory to modern society, social affiliation and the attendant options and expectations for individuals are no longer fixed. Their inclusion or exclusion is thus orientated towards their personal past, their biography as a history of inclusion or exclusion. ${ }^{6}$ With the 'institutionalization of the life course' (Kohli 1985; Meyer 1986) a person's past becomes a piece of information upon which expectations about the future can be based.

The observation and identification of individuals on the basis of their biography means transposing this observation from the social to the temporal dimension (Hahn 1988; Luhmann 1989). This transposition is consolidated structurally in the relations of inclusion and distribution of modern society, on the basis of its connectivity for organizations, individuals and welfare states. For organizations it makes the problem of the inclusion of individuals and of the regulation of standards of inclusion soluble; welfare states, by focusing on individuals' life courses, gain a classification scheme on which they can base the political mediation of the relations of inclusion; individuals, finally, gain opportunities for orientation which at the same 
time align them with the conditions of inclusion of the function systems and organizations.

Life course and career constitute social forms. They provide organizations and individuals with an order of social inclusion which can offer orientation, and with this the problem of the distribution of individuals across membership positions gains a form of solution. It becomes possible to observe individuals with regard to whether their past, documented as life course and career, makes it probable or improbable that they will fulfil the requirements of membership roles.

Further expectations can then be added. Careers formulate claims for inclusion in two directions: careers in education and training, as well as the work experiences which follow, make it possible to expect that individuals can be utilized for highly specified membership roles on the basis of their qualifications and skills, and therefore also the communication of corresponding expectations of performance. Conversely, such expectations form the basis for demands with regard to workplace furnishing and equipment, the position in the organization, and related decision-making powers, income level, prestige, etc. Orders of distribution can therefore be formed by way of these expectations. Organizations thus gain the opportunity to utilize individuals to cope with an uncertain future and for related expectations of performance which cannot be fixed in advance, because they promise them a career and thus continuability and security thereof.

On the one hand: the less the satisfiability of the requirements associated with a membership role is attributed to the individual bearers of this role and their specific background, the lower the career value of this membership, the attendant specifiability of performance expectations - and conversely the chances of making demands for rewards. Clusters of tasks which can be carried out by any number of people make the individual easy to replace. On the other hand these kinds of chances to make and enforce demands can themselves be increased by organization: associations such as trade unions and professional associations are organizations which form reflexively on the basis of the conditions of inclusion in organizations, the criteria for access, the performance expectations and the associated distributions of income, power and prestige. With their formation they aim at the stabilization and securing of achieved conditions of inclusion, by bundling, formalizing and standardizing careers in occupations and attached rights. This has been a central theme of occupational sociology since Max Weber. ${ }^{7}$

National welfare states form the central context for the way in which organizations focus on life courses and careers when including individuals, and distribute positions and incomes, and also for the formation and establishment of organizations which deal reflexively with the conditions of membership in organizations. Modern welfare states are, for all their differences, characterized in their organizational infrastructure by their reflexive 
relationship to modern society's form of inclusion/exclusion; this constitutes their common ground. Inclusion and exclusion in the social systems of modern society prove to involve many prerequisites and risks. Welfare states seek to mediate these conditions of inclusion and exclusion politically with their decisions. Historically they have focused their attention, in the first instance, on dealing with the risks of exclusion in the labour market, and have gradually expanded their focus to include the risks of exclusion in the education, legal, political and health systems, and in family systems.

To mediate these risks, welfare states begin with the cumulative relationship between the economy and organizations. The recruitment of personnel, the allocation of positions and careers in organizations are connected to the allocation of money, reputation and influence, and also to economic, cultural and social capital. These allocations have been a central point of reference for welfare states from the beginning. The form of membership and the conditions for the successful utilization of individuals for this membership open up and mediate very differently distributed opportunities for services in organizational and functional contexts, in which individuals do not occupy service roles, but complementary or service-receiving roles (Stichweh 1988) as consumers, voters, clients, laypeople, patients, audience or students. In the case of consumption, this is obvious. But health opportunities, too, and the capacity to enter into legal conflicts, success in educational organizations or the chances of gaining influence in politics are regulated in varied ways by organizational career patterns and the distributions of money, status, influence and contacts which are mediated through them. By attempting, in focusing on conditions of inclusion in organizations, to create opportunities and willingness for inclusion, and by dealing with the consequences of exclusion, welfare states aim to increase the above-mentioned, organizationally mediated opportunities for participation, and above all to make them transferable.

The central framework for the organization of this kind of increase and transferability is constituted by the institutionalization of the life course, a way of imposing order on the lifelong relationship of loyalty and service between national welfare states and their citizens. The lives of individuals are temporally structured here by a cluster of regulations as a sequential programme of social inclusion and exclusion. Modern organizations can rely on the life course and career as social ways of observing individuals, not least because welfare states create central prerequisites for individuals to be able to fulfil corresponding expectations. With the introduction of forms of intervention which are organized on the one hand with reference to families and on the other hand in line with the ways individuals are employed in organizations, with the temporal accumulation of rights and entitlements which are dependent on length of employment, and with the intervention in the conditions of inclusion and exclusion (e.g. through 
protection against dismissal, accident regulations, collective bargaining law), the welfare state establishes the social concept of the life course as a sequential programme (Kohli 1985). The welfare state thus produces essential prerequisites for organizations to be able to order inclusions and exclusions of individuals on the basis of career, by increasing the probability that careers can actually be achieved.

It is not difficult to see that social orders which are found for conditions of inclusion and exclusion in organizations, for the distribution of social resources such as money, power, influence and status and for opportunities to participate in the various function areas, are formed in parallel to the institutionalization of the life course and following the associated structural specifications. When defining occupations, formulating the conditions in which they can be pursued, making claims for income and social security, refusing unreasonable expectations for inclusion ${ }^{8}$ or monopolizing skills, organizations such as trade unions, entrepreneurs' associations, professional associations or chambers invoke criteria such as education and training, qualification, professional career, family status, age or gender, and combine them in such a way that their claims can in each case be defended and justified. For organizations, such specifications not only make the question of the inclusion or exclusion of individuals decidable, or make decisions which have already been taken explainable, ${ }^{9}$ but also provide representable criteria for the allocation of social resources such as income, power, status and influence. Organizations in different functional areas such as the economy, politics, mass media, health and academia deal with these criteria in manifestly diverse ways. An important factor here is whether organizations obtain money on a political basis or through the market, whether they are organizations pursuing ideological aims or organizations which offer 'extraordinariness' as a service, as for example in sport. Nonetheless such criteria help to formulate comprehensive and general points of orientation for decision-making, which make questions of inclusion and distribution manageable and thus make organizations which deviate greatly from this observable. $^{10}$

The resulting orders of inclusion/exclusion and distribution differ considerably from one national welfare state to the next (Esping-Andersen 1990, 1996), depending on their structure, and the shape of the institutionalized life-course patterns and the focus of the welfare-state mediation of the relations of inclusion differ accordingly. ${ }^{11}$ As a result different orders of inclusion and distribution emerge from country to country, connected in each case with different risk structures in relation to inclusion and exclusion and to the more or less restricted access to social resources. These orders become visible as social structures: ${ }^{12}$ as structured social inequality, as registered by inequality studies with the subsumption of individuals in categories of stratification; as differentially distributed labour market opportunities dependent on qualification, stage in life and gender; as more or 
less extended periods of income poverty, which vary in ways specific to stratum, phase in life, and gender (Leibfried et al. 1995; Leisering \& Leibfried 1999); as the probability or improbability of re-inclusion in work and income or as the codification of the organized need for help in different types of welfare state (Esping-Andersen 1996; Ganßmann \& Haas 1999; Goodin et al. 1999).

The achievement of the orders of inclusion/exclusion and of distribution, such as they result from the interplay of organizations and welfare states described here, and of the corresponding semantics in the functionally differentiated society, consists in the fact that questions of inclusion and distribution receive an ordering structure which encompasses the function systems and organizations and has its impact in the organizations of the various function systems, in a manner specific to each context. Such a structure, for the duration of its validity, removes the burden of finding new answers to questions of inclusion and distribution, specific to each organization and function. The effects of such an order are ambivalent: its relative stability gives organizations and function systems space for the process of differentiation, since the stabilization of expectations of inclusion and distribution means that individuals can be utilized for quite improbable and uncertain tasks. Welfare states have therefore, beyond their self-description, encouraged social differentiation more than social equality (Halfmann \& Bommes 1998). On the other hand, however, orders of distribution can tie up or overtax the resource potential of organizations. If their options for development are too severely restricted or even destroyed, such orders erode. They can also, however, lose a part of their binding force because of the loss of sovereignty of welfare states. ${ }^{13}$

\section{On the production of ethnic inequality in organizations, based on the example of the "Gastarbeiter" in Germany}

At the end of the 1980s there was a debate in the Zeitschrift für Soziologie between Hartmut Esser (1988), Reinhard Kreckel (1989) and Armin Nassehi (1990) about whether the renewed relevance of ethnicity in the wake of migration processes and conflicts over regionalism, and related discussions about inequality and discrimination, were test cases for the kinds of social theory exemplified by systems theory, test cases which these theories would barely be able to survive. Against this background it is widely taken as read that there is little to be gained from this field for research into ethnic inequality. In the light of the largely unchanged state of this discussion, I would like to sketch below, using the example of the earlier "Gastarbeiter" (literally "guest workers"), how one can use the reflections presented to understand more precisely what positions of distribution these migrant workers of the 1960s and 1970s and their descendants have 
attained, and in what way these distributions are ethnically structured or are registered as ethnic inequality by those involved. ${ }^{14}$

What inclusions and thus what access to resources migrants can empirically achieve depends, for them too, on the observation and processing of their careers in organizations themselves. The absence of continuous careers of inclusion and associated expectations of qualifications and income is not a problem for organizations in all circumstances. Welfare states mediate the conditions of inclusion of organizations and function systems, and the chances of migrants, through prohibitions, permissions, and services. With the structure of their way of operating they stipulate orders which reward various types of seamlessly positive careers of inclusion, and, as a complement to this, formulate orders of exclusion for those individuals who are "deficient" in diverse respects. But inclusion is carried out in organizations which, in focusing on the state's specifications or trying to circumvent them, initially and primarily solve their own problems.

If one wishes to clarify the relationship of migrants to organizations and the attendant opportunities for inclusion and distribution, then it is necessary to specify in which respects, in their attempts to access organizations as members in service roles, particular characteristics which have their roots in their migrant status and the attendant structural consequences come into play in comparison to other individuals. This is discussed below in three steps: I. If the careers of migrants diverge from the normal expectations institutionalized in the welfare state, this has differentiated consequences for their chances of inclusion and the related access to resources in organizations, and does not necessarily mean exclusion or discrimination. On the contrary, for a relevant portion of migrants there is a correlation between the lack of a career of inclusion on which demands might be based, low expectations of income, and resulting chances of inclusion. II. Inclusion in organizations is not exclusively dependent on career. Careers formulate prerequisites for inclusion, but whether they actually ensure entry depends largely on the recruitment structures in organizations and the kind of access one has to those making decisions about recruitment. The positions in organizations which are attained and attainable as a continuing process at the beginning of a migration process and in the course of its establishment are, in contexts of inclusion mediated by the welfare state, the determining factor for the chances for inclusion and access of subsequent migrants and of the children of migrants, the so-called second and third generations. III. State categories of immigration correspond to self-attributions and attributions by others of ethnic or national characteristics and qualities which express the legitimacy or illegitimacy of residence and benefit claims, and also expectations about the so-called capacity for integration. Such attributions and expectations are socially valorized in various communicative contexts (Bommes 1994). They gain relevance in organizations as migrants are included in both service and service-receiving roles, 
and they find their way into the organizations' decision-making programmes, if such distinctions are able to be used for the solution of decision-making problems.

\section{I}

In modern society, migrant workers' chances for inclusion in labour markets have historically been based on their willingness to provide a greater work output for lower income expectations than those workers already present. In other words: migration as geographical mobility to take advantage of opportunities for inclusion in organizations, for the purpose of achieving income, is made possible and induced by inequality in the sense of different structures of inclusion and distribution in the region of origin and the target region. After the implementation of freedom of movement in the internal labour market, the modern nation state, now expanded into a welfare state, intervened in migrant workers' willingness to be mobile, insofar as they were foreigners, by controlling access to the local labour market to protect the standards of inclusion for domestic workers (standards politically mediated by the welfare state) against competition from outside. If migration is based on chances for inclusion which arise from a different context of inclusion and distribution, then welfare states, by institutionalizing a barrier of inequality towards the exterior, create incentives to crossborder migration, structurally and permanently, while at the same time trying to make the possibilities for achieving this dependent on their own premises (Bommes 1999).

In this way, the European states have attempted to regulate labour migration. In doing so they have focused their efforts to control access to the state-defined labour market on criteria concerned with providing a sufficient supply of labour for the "national economy" and with the employment and privileging of their citizens. With the process of labour migration after World War II, which was given various kinds of administrative support in the individual countries, these states offered interested businesses on the premise of the "Inländerprimat" (preferential treatment of nationals) - access to individuals from other states, young and eager for inclusion. The attractiveness of these individuals for the businesses, despite or also because the migrant workers were included in the general compulsory social insurance scheme, consisted not only in their high general productivity, which was assured by corresponding selection procedures, but also in their "careerlessness". They were able to be deployed, mainly in the manufacturing industry, in workplaces demanding high levels of physical labour, as unskilled or semi-skilled workers in low wage brackets. Orientated towards the relations of inclusion, distribution and income of their regions of origin, they had a high willingness to work and perform and, in comparison to the domestic workers, lower pay expectations. 
The inequality of the migrant workers of the first generation was the starting point from which they were able to grow into relatively stable relations of employment in the areas of production for which they had been recruited and, connected with the conditions of their employment related to social-security law, into the status of "denizen" (Hammar) with permanent residence and comprehensive rights to the benefits of the welfare state. In settling here, they developed into a population which was able to maintain its position in its own specific labour markets - to varying extents - from the early 1980 s to the mid-1990s. ${ }^{15}$ Their fields of activity were affected by constant processes of rationalization and restructuring, due to international economic developments; this largely explains a phenomenon observable in almost all countries, the high proportion of migrant workers among the unemployed in comparison to each country's nationals.

However different the political reactions to the circumstances of the migrant workers and their families were and are in the different countries, it was only as they grew into the role of "denizens" that "integration" became the focus of their treatment by the welfare state. With the attainment of permanent residence and entitlement to the benefits of the welfare state, they were gradually inserted into its frame of reference of "equality", the community of legitimate beneficiaries. The desired "equality" in the sense of "integration" also meant assimilation to the relations of inclusion and the lifestyle of the nationals.

It was only with the shift to "integration" and thus to "equality" that the specific structure of inclusions of the migrant workers and the associated distributions, the potentially discriminatory regulations of their conditions of immigration and residence, and their structurally weaker position in relation to the compensatory mechanisms of the welfare state became a normative problem in terms of their inequality-producing character in comparison to the relations of inclusion of the nationals. This problem was exacerbated in the 1990s, particularly in relation to that part of the second and third generation which had grown up in this welfare-state frame of orientation favouring equality as the condition for better opportunities for participation in other functional contexts and organizations, without being able to overcome existing barriers to inclusion in workplaces with higher income and greater employment security.

\section{II}

In summary, for a large part of foreign migrants the opportunities for access to organizations as members in service roles and the attendant opportunities for inclusion and distribution have arisen from their inequality with regard to career assets and welfare-state safeguards in comparison to nationals. The assets and safeguards connected to their migrant status initially form the basis for their opportunities for inclusion and income. With the 
inclusion of migrants into the welfare-state programme of integration, however, migrants and the children who come after them run into considerable barriers to mobility and difficulties gaining access to organizations. The obvious disadvantaging of "integrated migrants" in the labour market raises the question of peculiarities in their relationship with organizations which hamper their efforts to enter into the "normal working conditions" of the nationals. This phenomenon can be found in all countries. It is reproduced in organizations in various ways, depending not least on the different modes of welfare-state mediation of their structures of inclusion, but also on the history of immigration. It points to the mechanisms in organizations themselves, which reproduce their membership structure in different ways by granting their members opportunities to keep their positions, control access within networks, and exclude third parties. The following section will demonstrate, using the example of the barriers to mobility encountered by migrant workers in organizations in Germany, and the obvious difficulties of second-generation migrants in accessing on-the-job training positions, some of these kinds of structures of inclusion in organizations, which make it difficult for migrant workers to take on better paid service roles with more potential for the future, and which largely limit them to a lifestyle conditioned by restricted opportunities for inclusion. ${ }^{16}$

In Germany, where unemployment rates were slightly lower than in France or the Netherlands (Werner 1994), but also rising sharply (Thränhardt 1998), migrant workers achieved no significant improvements by the beginning of the $1990 \mathrm{~s}$, but did manage to secure their positions within companies or in occupations. Hardly any, however, make the shift into the service industry; they thus remain largely excluded from this worldwide trend towards a restructuring of employment conditions. Both within and outside the workplace, foreign nationals were and are confronted with considerable barriers to mobility, correspondingly lower chances of income and greater risks of redundancy (see for example Thränhardt, Dieregsweiler \& Santel 1994; Seifert 1995; Thränhardt 1998).

The securing of their membership mentioned above is, above and beyond the consolidation of their situation in relation to social law, an indication of their productivity in the positions they occupy. If they display restricted mobility from these positions, this is in the first instance because of their unequal career assets, outlined above, which originally provided the basis for their chances of inclusion. When it comes to orienting their lifestyle towards equality in the sense set out above, this under-endowment with formal career characteristics as part of the order of inclusion mediated by the welfare state is an obstacle to mobility. Studies on internal and external mobility in the labour market ${ }^{17}$ show, however, that foreign migrant workers always had and have fewer chances than local workers with the same career assets of leaving their positions to take up jobs associated with more skills, lighter work, and a higher income. This phenomenon cannot 
be explained by different orientations towards mobility, since it applies to migrants of both the first and the second generation. Furthermore, occupational processes of upward and downward mobility show that migrant workers experience much less upward mobility and more often experience downward mobility than their German colleagues, who also move more successfully into white-collar occupations in the tertiary sector (Seifert 1995: 166ff.; Schäfer 1994: 143f.).

Of central significance is the fact that the principle of seniority, institutionalized in the industrial production sector, according to which the length of service to the company constitutes the main criterion for the selection of individuals for internal processes of mobility (Windolf \& Hohn 1984), is applied only to a limited extent in the area of the employment of foreigners. While the whole spectrum of possible improvements is open to local workers, largely independent of their initial qualification, and the risk of their career being confined to areas of activity with fewer skills, harder work, and low income is far lower, the spectrum of options for advancement is highly restricted for foreign migrant workers, differentiated internally by nationality. The principle of seniority only applies for them within this spectrum. In this way particular national groups remain largely in the segments of the workplace in which they were first employed (Biller 1989).

The decisive factor for these different opportunities is the chance to participate in internal social networks in which decisions about recruitment, further qualifications and promotions are made, or the access to members of such networks of decision-makers or decision-preparers (Dohse 1982; Schäfer 1985; Gillmeister, Kurthen \& Fijalkowski 1989). Due to the duration of their period of service, and their memberships in trade unions and works committees, foreign migrant workers are not cut off from internal decision-making networks. They have considerable influence on decisionmakers as the personnel-related premises for recruitment decisions and have established, for their workplace domains of employment, the expectation that when jobs are available, considerable weight will be accorded to their advocacy or kinship relationships to them in the recruitment decision. Despite declared efforts on the part of unions (Kühne, Öztürk \& West 1994), they are not, however, involved in the same way in networks of communication about opportunities for transfer and promotion, and thus are mainly taken into consideration in those distributions which pertain to the spectrum of mobility and career which they are recognized as having within their workplace. This process by which migrant workers become fixed in the positions held also draws on their formal career assets as a basis for decisions. In this way the non-consideration of migrants in decisions about qualifications becomes communicable as an expectation that they will have a limited capacity for further training, which is in turn attributed 
to ethnic-cultural barriers, and is then representable as part of the approved order of inclusion and exclusion.

Once established, such structures of communication acquire a self-reinforcing character on the basis of the "self-recruitment" of the migrant workers for the workplace positions which are predominantly occupied by them, since they reproduce the networks of groups distinguished by ethnicity or nationality, as the case may be, the expectations institutionalized within the workplace regarding the career options of such groups and thus the complex of workplace networks, in which distributions are organized along the structure of mobility outlined above. In this way, in the manner in which members are recruited internally and assumptions are made about career scope, social processes of distribution and closure crystallize, and are reproduced and supported, as well as in some cases ethnically marked, in social networks of communication.

With criteria for the opening and closing of careers which are institutionalized in this way in the workplace processes of communication, migrant workers are largely bound to the inclusion structures and the associated distributions and horizons of possibilities which initially made possible their entry and thus their migration. The relations of inclusion and distribution within organizations established with labour migration have been difficult for migrant workers to break through to this day, partly because the networks which allocate the places to them, and they themselves in their perception of the options open to them, reproduce the structural context in which the limiting of their horizon of possibilities is institutionalized. Evidently, social networks or their members in organizations are not easily impressed by general appeals to integration and equality when it comes to taking advantage of opportunities on the paths of the orders of inclusion which are open to them and which they reproduce, individually or in combination with all the others, for the production of decisions about positions and distributions.

At the same time the manner in which migrant workers also participate in the reproduction of the orders of inclusion and distribution makes it clear why the external horizon of mobility, improving one's situation by changing workplace, is limited for them. The external recruitment of members for available positions is also largely mediated via social networks (Windolf \& Hohn 1984; Sengenberger 1987), because the scope for indeterminacy and uncertainty which decisions about recruitment and allocation have to absorb is limited by such networks ${ }^{18}$ and for this very reason opens up decision-makers to the expectations which members address to them. Insofar as migrant workers are, here too, dependent on access to the networks which they can reach, they are obviously not getting anywhere. This constitutes at the same time the central mechanism by means of which a large part of the second generation of migrants succeed their fathers when taking up membership positions. 
Where second- or third-generation migrants compete with young Germans for apprenticeships, on the basis of the same school-leaving qualifications, ${ }^{19}$ social networks again prove to be the deciding factor for the allocation of places in businesses. In recruiting young people for apprenticeships, staff are capable of making their expectations the basis for decisions, and in this way reserving access mainly for their own children, relatives, and other participants in their social networks (Bommes 1996; Faist 1995: 110ff.). True, migrant workers also take part in this as members of staff. But because of the significance of such networks the parts of the business to which they have no access as members prove to be closed to their children as well.

The effect of this is that migrant workers "bequeath" to their children, in a modified form, the structures of inclusion, distribution, and horizons of possibilities to which they are structurally confined within their organizations, against the background of the history of their recruitment. They attempt successfully to offer access to membership positions in the area of unskilled or semi-skilled activities to young people who are unable to enter training positions due to a lack of school-leaving qualifications. In many cases they can use the channels of their networks to place those young people who fulfil the academic prerequisites in training positions. Because migrant workers are predominantly employed in industrial production, this means that the young people mainly become qualified in occupations which often have poor prospects for the future, given the constant processes of restructuring in industrial production. Furthermore, because of the tight control exercised by bodies of workers over young people's access to training positions, migrant youths who are looking for an apprenticeship are largely relegated to the less attractive apprenticeships in manual work, and those with less future potential for subsequent careers.

These opportunities for migrant youths to access on-the-job training and the attendant future chances of inclusion and income are the result of the interplay of the orders of inclusion in organizations and the way they are mediated by the welfare state. In Germany a part of the organization of occupational training is the neocorporative arrangement by which companies have repeatedly committed themselves to providing enough apprenticeships for young people - resulting in relatively low (in international terms) youth unemployment (Faist 1995). The structures of inclusion in organizations, however, on the basis of this welfare-state arrangement, regulate access to the available apprenticeships in a way which largely steers migrant youth into the paths of inclusion, the career prospects, and the related chances of income of their parents. The positions in organizations which were attained and attainable by them with their migration thus turn out, in contexts of inclusion mediated by the welfare state, to be a significant prestructuring for the chances of inclusion and opportunities for access of the following generations. The initial disadvantage of the parents, which was originally their 
advantage, sets in motion a non-random formation of order, in which a considerable portion of the children are also included, and which leads to stabilization of initial disadvantages across various functional areas in the sense of reduced opportunities for participation and capacities for using opportunities. Inequality studies describe this, summarizing the cumulative effects statistically, by assigning them to the lowest division of a stratification model (Geißler 2002).

\section{III}

Part of this kind of formation of order is the development of lifestyles which allow the integration of the typical clusters of opportunities for integration into structured situations in life, as well as the use and condensation of descriptions which allocate a meaning to those lifestyles. In the case of migrants, these attributions of meaning, particularly the attribution of characteristics and qualities to those leading such lifestyles, are embedded in ethnic or national semantics and closely related to the state immigration categories ("foreign national", "asylum applicant", "Aussiedler" [person of German descent returning to Germany from Eastern Europe]), which indicate the extent to which conditions apply to their residence, and the more or less limited legitimacy of their relationship to the welfare state. Such descriptions of self and other are part of the fixing of orders of inclusion and their social evaluations. They make individuals socially distinguishable and observable with regard to whether they can be considered for inclusions and associated distributions, and if so, for which ones.

In theories of ethnic conflicts and discrimination, such processes of attribution are mainly described as part of disputes between individuals or collectives over resources for the satisfaction of material needs and for social recognition. Ethnic or national distinctions are undoubtedly also made relevant in communication processes, when attempts are made to discriminate against or to improve the position of individuals or collectives in disputes over distribution. But insofar as this is meant to acquire meaning for the chances of participating in distributions, such distinctions must above all take effect and attain connectivity in the communication processes of organizations, because it is here than the relevant inclusions and distributions occur. The reference to organizations redirects attention to their process of reproduction. The connectivity of distinctions which contribute, in their communicative effects, to the integration of migrants' opportunities for inclusion and distribution, can be measured here by their reusability in producing decisions. What is questionable is how and in what way organizations resort to ethnic or national semantics and distinctions made by the state for the description of migrants to solve their decision-making problems, and what consequences this has for migrants' chances of inclusion in 
service or service-receiving roles, and their related chances of access to material and symbolic benefits.

For the inclusion of migrants in service roles, it is obvious that, where their willingness to be included is no longer based on an orientation towards the advantage of inequality, the concept of career as a form of observing order opens up the possibility of describing their career assets as deficient in various respects. Here it is possible to evoke not only formal educational requirements, but also assumptions about culturally different lifestyles, associated mentalities, etc. Such forms of description reduce the scope for indeterminacy and uncertainty which has to be absorbed by decisions about recruitment and allocation, and in some cases find reinforcement both in the self-presentation of the migrants and in descriptions of migrants found in educational contexts, politics or academia. Whether businesses resort to such descriptions depends on their internal organizational history, the positions filled by migrants in them, the role of the works committees and unions, and the structure of the internal social networks. ${ }^{20}$ Because of the orders of inclusion mediated corporatively by the welfare state, however, it is no coincidence that in Germany - unlike the USA, where the relevance of ethnic distinctions is politically fixed by "affirmative action" programmes - ethnic disputes have hardly featured in those workplaces regulated by "industrial relations". The formal, career-related orders of inclusion, in combination with the above-described forms of workplace recruitment, stabilize the established structures of inclusion and distribution and the related systematic impediments to inclusion of migrant workers and their children, without recourse to an elaborate, explicitly ethnic repertoire of attributions. Conversely, this on the one hand does not exclude the possibility that those affected by such forms of distribution will withdraw into ethnic networks and lifestyles, but makes this outcome likely (Esser 1985). On the other hand, patterns of explanation and legitimation which ascribe these disadvantages to ethnic-cultural backgrounds are becoming more relevant. With the current shift in "industrial relations" (Streeck 1998), moreover, the expansion of a service industry for low-paid activities unregulated by the welfare state, an industry which is also differentiated in ethnic terms, has increased and with it the significance of the use of such distinctions for the allocation of opportunities for inclusion.

It is therefore necessary to distinguish between the production and the presentation of social inequality. The production of the social positions of inequality of the Gastarbeiter and their children can largely be understood as, in the first instance, the result of organizational decisions embedded in the welfare state, which rely on more or less established and semantically straightforward routines for the recruitment of members by internal networks. To the extent that ethnic semantics find their way into the social registration of this inequality, its causes and its consequences, both among those affected and those observing them in decision-making positions, in 
welfare-state administrations and other relevant areas of life, these semantics will be a part of the reproduction of this inequality.

\section{Conclusion}

The first section of the text proposes that we understand orders of distribution and the related semantics as the combined result of the solutions which organizations find for their structural problems, and of the related political forms of regulation of the welfare state which thereby solve its problems. It follows from this proposal that inequality studies should focus more on organizations in function systems as a type of social system and their form of reproduction, since the structure of the distribution of social resources is part of the reproduction of organizations. Previous inequality studies, with their preference for individual and collective actors, have largely ignored this connection. The second part shows, using as an example the career of the "Gastarbeiter" and their children in the labour market, and the resulting inequality, frequently understood as ethnic, that this form of inequality has also formed around the structures of the functionally differentiated society, and that it can largely be understood as the result of the interplay between decisions about recruitment and distribution in organizations, and the way these are embedded in the welfare state.

\section{Notes}

I The text makes extensive use of two other pieces of work: an essay which, in dialogue with inequality research, explains in more detail why it could be worthwhile connecting with systems theory in this field (Bommes 200I), and excerpts from chapter 6.3 in Bommes (I999).

2 The value of equality is, of course, already present in Christianity, for example, but it is only in modern society that it becomes anchored in society's structure of differentiation.

3 This was evoked early on to counter the functional theory of stratification of Davis and Moore (I940).

4 The thesis of the primacy of functional differentiation does not imply that one must choose between analysis of differentiation and analysis of social inequality (Schwinn I998: I5). The thesis of the primacy of the form of differentiation states that structures of social inequality are more or less closely coupled with a society's particular form of differentiation and rest on this. In this sense structures of distribution and the social ways of registering issues of inequality presuppose the particular form of differentiation: they shape themselves around this, are limited by it and conversely have reciprocal effects on the structural development of society - as is easily observable in the emergence of welfare states in modern society.

5 More than 90 per cent of all those in paid employment derive their income from assuming service roles in organizations. More than 90 per cent of the adult resident population in the wealthier countries (Europe, USA, Canada, Australia, Japan) derive 
their income from paid employment, welfare-state transfer income, or familial support.

6 Historically this transition becomes apparent in, for example, the increasing importance of the career in modern state administration, with this criterion eventually taking the place of that of descent, thus overriding the previously privileged access of the aristocracy.

7 Cf. for example Beck, Brater \& Daheim 1980; we leave aside here the interesting fact that, beyond these debates, occupations and professions must primarily be understood, following Parsons, as the result of a mutual cumulative relationship between the education system and organizations: from qualifications and occupations, organizations derive orientation for defining positions and associated expectations of skills; the education system and its organizations align their provision of certificates and qualifications with the job market and the expectations of organizations (Stock 2002). The success of the education system, in providing services which can be taken up by other systems, then obviously has consequences for the distribution of resources, concerning both the flow of money into the area of training and also the social status which can be attained there.

8 Such as: "On Saturdays Dad belongs to me."

9 Such criteria make the awarding of positions representable, but in many cases not decidable, because there is no clear relationship between positions and individuals who could potentially occupy them. In numerous organizations there are highly formalized application procedures which make recruitment from both within and outside the organization representable and immunize against accusations of arbitrariness and patronage. The actual determining factors are then, however, criteria such as relationship, neighbourhood or other network affiliations which staff successfully use as criteria to influence the decision-makers. Social networks develop around the internal recruitment of members and, based on this, social processes of distribution and closure. Such networks support the established criteria for the judgement of careers, since these criteria are used as socially legitimate descriptive patterns for the representation of the awarding of positions. We will return to this in the third section about ethnic inequality.

Io Thus for example when it comes to paying their staff in hospitals or kindergartens churches cannot deviate greatly from the standards in other comparable institutions by citing the religious requirement for charity. And the salaries of sportspeople and media stars attract attention not least in terms of deviation - extraordinariness, in a word.

II E.g. focusing on the "male average wage-earner" as in Germany or on the compatibility of paid employment and family, as in Sweden.

I2 We should not overlook here the fact that the distribution of social resources also occurs to a considerable extent outside such orders. One might consider for example drug-dealing, prostitution, crime, the so-called shadow economy, illegal migration etc. Such distributions are seen in part as illegitimate and/or illegal and they are opportunities to reclaim the legitimate order. They largely fall outside the models used in inequality studies to describe the social structure.

I3 Discussions about the waning power of welfare states in the context of globalization, about the destructuring of social inequality, the erosion of 'normal employment', the breaking away of the demographic foundations of the social security systems indicate the current processes of erosion affecting such orders. But current processes of change are occurring under the auspices of the restructuring of the orders of inclusion and distribution, not of their disintegration. Also affected by this are the structure of welfare states, the organizational conditions for the enforcement of demands, the semantics of inclusion/exclusion and of distribution. But falling incomes, 
reduced services from welfare states and reduced social security are not to be equated with the disintegration of order.

I4 A distinction should be made between statistically describable structures of distribution - here differences in dimensions of distribution such as income, education, occupational position, etc. which are significant for national or ethnic groups can be demonstrated regularly - and the social perception and handling of such structures as differences which are rooted in or can be justified by ethnicity or nationality.

I5 Cf. the comparative studies of Werner (1994); Seifert (2000) and for Germany Thränhardt, Dieregsweiler \& Santel (1994); Seifert (I995).

I6 Thus, this is not about explaining the inequality of migrants, but about showing how some central mechanisms of its production can be made transparent in the theoretical frame of reference detailed above.

I7 For this cf. Thränhardt, Dieregsweiler \& Santel (I994): 66ff.; Seifert (I995): I65ff.; Gillmeister, Kurthen \& Fijalkowski (1989); Biller (1989), the relevant articles in Kühne, Öztürk \& West (1994).

I8 For a concept of networks elaborated in systems-theory terms, and shedding structural-theoretical light on the solidification of networks around the opportunities to make decisions about personnel recruitment, cf. Tacke (2000).

I9 For a discussion of the educational success of migrant children or their educational disadvantage (which we do not go into here) see Hunger \& Thränhardt (2003).

20 It is also necessary to distinguish between on the one hand the way members of an organization present a decision in studies of their hiring behaviour, and the semantics which they resort to in the process (as in Gillmeister, Kurthen \& Fijalkowski I989), and on the other hand the production of a decision which can generally rely on communicatively straightforward agreements and routines.

\section{Literature}

Beck, Ulrich, Michael Brater \& Hansjürgen Daheim (1980), Soziologie der Arbeit und der Berufe. Grundlagen, Problemfelder, Forschungsergebnisse. Reinbek: Rowohlt.

Biller, Martin (1989), Arbeitsmarktsegmentation und Ausländerbeschäftigung. Ein Beitrag zur Soziologie des Arbeitsmarktes mit einer Fallstudie aus der Automobilindustrie. Frankfurt am Main/New York: Campus.

Bommes, Michael (1994), 'Migration und Ethnizität im nationalen Sozialstaat', in Zeitschrift für Soziologie 23, pp. 364-377.

Bommes, Michael (1996), 'Ausbildung in Großbetrieben: Einige Gründe, warum ausländische Jugendliche weniger Berücksichtigung finden', in Ralph Kersten, Doron Kiesel \& Sener Sargut (eds), Ausbilden statt Ausgrenzen. Jugendliche ausländischer Herkunft in Schule, Ausbildung und Beruf. Frankfurt am Main: Haag + Herrchen, pp. 31-44.

Bommes, Michael (1999), Migration und nationaler Wohlfahrtsstaat. Ein differenzierungstheoretischer Entwurf. Wiesbaden: Westdeutscher Verlag.

Bommes, Michael (2001), 'Organisation, Inklusion und Verteilung. Soziale Ungleichheit in der funktional differenzierten Gesellschaft', in Veronika Tacke (ed.), Organisation und gesellschaftliche Differenzierung. Wiesbaden: Westdeutscher Verlag, pp. 236-258.

Bommes, Michael \& Veronika Tacke (2001), 'Arbeit als Inklusionsmedium moderner Organisationen. Eine differenzierungstheoretische Perspektive', in idem (eds), Organisation und gesellschaftliche Differenzierung. Wiesbaden: Westdeutscher Verlag, pp. 61-83.

Davis, Kingsley \& Wilbert E. Moore (1966 [1940]), 'Some Principles of Social Stratification', in Reinhard Bendix \& Seymour M. Lipset (eds), Class, Status, and Power. New York: Free Press, pp. 47-53. 
Dohse, Knuth (1982), ‘Ausländische Arbeiter und betriebliche Personalpolitik', Gewerkschaftliche Monatshefte 7, pp. 427-438.

Esping-Andersen, Gøsta (1990), The Three Worlds of Welfare Capitalism. Cambridge: Polity Press.

Esping-Andersen, Gøsta (ed.) (1996), Welfare States in Transition. National Adaptations in Global Economies. London and elsewhere: Russel Sage Foundation.

Esser, Hartmut (1985), 'Soziale Differenzierung als ungeplante Folge absichtsvollen Handelns: Der Fall der ethnischen Segmentation', Zeitschrift für Soziologie 14, pp. 435449.

Esser, Hartmut (1988), 'Ethnische Differenzierung und moderne Gesellschaft', Zeitschrift für Soziologie 17, pp. 235-248.

Faist, Thomas (1995), Social Citizenship for Whom? Young Turks in Germany and Mexican Americans in the United States. Aldershot: Avebury.

Ganßmann, Heiner \& Michael Haas (1999), Arbeitsmärkte im Vergleich. Rigidität und Flexibilität auf den Arbeitsmärkten der USA, Japans und der Bundesrepublik Deutschland. Marburg: Schüren.

Geißler, Rainer (2002), Die Sozialstruktur Deutschlands, 3rd edition. Wiesbaden: Westdeutscher Verlag.

Gillmeister, Helmut, Hermann Kurthen \& Jürgen Fijalkowski (1989), Ausländerbeschäftigung in der Krise? Berlin: Ed. Sigma.

Goodin, Robert E., Bruce Headey, Ruud Muffels \& Henk-Jan Dirven (1999), The Real Worlds of Welfare Capitalism. Cambridge: Cambridge University Press.

Halfmann, Jost \& Michael Bommes (1998), 'Staatsbürgerschaft, Inklusionsvermittlung und Migration. Zum Souveränitätsverlust des Wohlfahrtsstaates', in idem (eds), Migration in nationalen Wohlfahrtsstaaten. Theoretische und vergleichende Untersuchungen (IMISSchriften 6). Osnabrück: Universitätsverlag Rasch, pp. 81-101.

Hahn, Alois (1988), 'Biographie und Lebenslauf', in Hanns-Georg Brose \& Bruno Hildenbrand (eds), Vom Ende des Individuums zur Individualität ohne Ende. Opladen: Leske + Budrich, pp. 91-105.

Hunger, Uwe \& Dietrich Thränhardt (2003), Der Bildungserfolg von Einwandererkindern in den Bundesländern. Diskrepanzen zwischen der PISA-Studie und den offiziellen Schulstatistiken. Arbeitspapier des Forschungsprojektes »Einwanderkulturen, Netzwerke und ihre Integrationsqualität. Eine komparative Analyse im Vergleich der Bundesländer und Zuwanderernationalitäten «. Institut für Politikwissenschaft, Universität Münster.

Kohli, Martin (1985), 'Die Institutionalisierung des Lebenslaufs', Kölner Zeitschrift für Soziologie und Sozialpsychologie 37 (1), pp. 1-29.

Kreckel, Reinhard (1989), 'Ethnische Differenzierung und moderne Gesellschaft. Kritische Anmerkungen zu Hartmut Essers Aufsatz', Zeitschrift für Soziologie 18, pp. 162-167.

Kreckel, Reinhard (1992), Politische Soziologie der sozialen Ungleichheit. Frankfurt am Main/New York: Campus.

Kühne, Peter, Nihat Öztürk \& Klaus-W. West (eds) (1994), Gewerkschaften und Einwanderung. Köln: Bund-Verlag.

Leibfried, Stephan, Lutz Leisering, Petra Buhr, Monika Ludwig, Eva Mädje, Thomas Olk, Wolfgang Voges \& Michael Zwick (1995), Zeit der Armut. Lebensläufe im Sozialstaat. Frankfurt am Main: Suhrkamp.

Leisering, Lutz \& Stephan Leibfried (1999), Time and Poverty in Western Welfare States: United Germany in Perspective. Cambridge: Cambridge University Press.

Luhmann, Niklas (1964), Funktionen und Folgen formaler Organisationen. Berlin: Duncker und Humblot.

Luhmann, Niklas (1985), 'Zum Begriff der sozialen Klasse', in idem (ed.), Soziale Differenzierung. Zur Geschichte einer Idee, Opladen: Westdeutscher Verlag, pp. 119-162. 
Luhmann, Niklas (1989), 'Individuum, Individualität, Individualismus', in idem, Gesellschaftsstruktur und Semantik. Studien zur Wissenssoziologie der modernen Gesellschaft 3. Frankfurt am Main: Suhrkamp, pp. 149-258.

Marshall, Thomas H. (1992 [1950]), Bürgerrechte und soziale Klassen: Zur Soziologie des Wohlfahrtsstaates. Frankfurt am Main/New York: Campus.

Meyer, John W. (1986), 'The Self and the Life Course: Institutionalization and its Effects', in Aage B. Sørensen, Franz E. Weinert \& Lonnie R. Sherrod (eds), Human Development and the Life Course: Multidisciplinary Perspectives. Hillsdale, NJ/London: Lawrence Erlbaum Associates, pp. 199-216.

Nassehi, Armin (1990), 'Zum Funktionswandel von Ethnizität im Prozeß gesellschaftlicher Modernisierung. Ein Beitrag zur Theorie funktionaler Differenzierung', Soziale Welt 41, pp. 261-282.

Schäfer, Hermann (1985), Betriebliche Ausländerdiskriminierung und gewerkschaftliche Antidiskriminierung, Berlin: Express-Edition.

Schäfer, Hermann (1994), 'Bei der Arbeit fast gleichgestellt?' in Kühne, Öztürk \& West, pp. 139-149.

Schwinn, Thomas (1998), 'Soziale Ungleichheit und funktionale Differenzierung. Wiederaufnahme einer Diskussion', Zeitschrift für Soziologie 27 (1), pp. 3-17.

Seifert, Wolfgang (1995), Die Mobilität der Migranten. Die berufliche, ökonomische und soziale Stellung ausländischer Arbeitnehmer in der Bundesrepublik. Berlin: Ed. Sigma.

Seifert, Wolfgang (2000), Geschlossene Grenzen - offene Gesellschaften? Migrations- und Integrationsprozesse in westlichen Industrienationen. Frankfurt am Main/New York: Campus.

Sengenberger, Werner (1987), Struktur und Funktionsweise von Arbeitsmärkten. Die Bundesrepublik Deutschland im internationalen Vergleich. Frankfurt am Main/New York: Campus.

Stichweh, Rudolf (1988), 'Inklusion in Funktionssysteme der modernen Gesellschaft', in Renate Mayntz, Bernd Rosewitz \& Uwe Schimank (eds), Differenzierung und Verselbständigung. Zur Entwicklung gesellschaftlicher Teilsysteme. Frankfurt am Main/New York: Campus, pp. 261-293.

Stock, Manfred (2002), 'Arbeiter, Unternehmer, Professioneller. Eine theorievergleichende Analyse zur sozialen Konstruktion von Beschäftigung in der Moderne' (Unpublished dissertation). Berlin: Freie Universität.

Streeck, Wolfgang (1998), 'Industrielle Beziehungen in einer internationalisierten Wirtschaft', in Ulrich Beck (ed.), Politik der Globalisierung, Frankfurt am Main: Suhrkamp, pp. 169202.

Tacke, Veronika (2000), 'Netzwerk und Adresse', Soziale Systeme 6 (2), pp. 291-320.

Thränhardt, Dietrich (1998), Regionale Ansätze und Schwerpunktaufgaben der Integration von Migrantinnen und Migranten in Nordrhein-Westfalen. Studie im Auftrag des Ministeriums für Umwelt, Raumordnung und Landwirtschaft des Landes Nordrhein-Westfalen. Institut für Politikwissenschaft der Universität Münster.

Thränhardt, Dietrich, Renate Dieregsweiler \& Bernhard Santel (1994), Ausländerinnen und Ausländer in Nordrhein-Westfalen. Die Lebenslage der Menschen aus den ehemaligen Anwerbeländern und die Handlungsmöglichkeiten der Politik. Landessozialbericht vol. 6. Ministerium für Arbeit, Gesundheit und Soziales des Landes Nordrhein-Westfalen.

Werner, Heinz (1994), 'Integration ausländischer Arbeitnehmer in den Arbeitsmarkt Deutschland, Frankreich, Niederlande und Schweden', in Beiträge zur Arbeitsmarkt- und Berufsforschung 178, Nürnberg, pp. 85-187.

Windolf, Paul \& Hans-Willy Hohn (1984), Arbeitsmarktchancen in der Krise. Betriebliche Rekrutierung und soziale Schließung. Frankfurt am Main/New York: Campus. 


\title{
4 Welfare systems and migrant minorities
}

\author{
The cultural dimension of social policies and \\ its discriminatory potential
}

First published in 2008 by the Council of Europe as a chapter (pages 129158 ) in Reconciling migrants' well-being and the common interest: Economy, welfare state and citizenship in transition (Trends in social cohesion 19), edited by Europarat

Reprinted in 2011 in 'Migration und Migrationsforschung in der modernen Gesellschaft' in IMIS-Beiträge 38 (pages 221-246)

The histories of welfare states and international migration in Europe after the Second World War are closely interlinked. The phase of expansion and consolidation of these welfare states from the 1950s until the 1970s was also the major period of post-colonial immigration and active recruitment of labour migrants, which constituted the main paths for subsequent migrations to Europe. The recent efforts of European welfare states to adapt their welfare systems to the challenges of increasing competition in globalised markets are connected internally with policies of migration and integration; they try to restrict access to state territories for migrants seen as insufficiently competitive on the one hand and, on the other, to enforce the social integration of long-term resident migrants as an integral, programmatic part of activating welfare policies. The infrastructure and policy designs of European welfare states still differ, and therefore so do the modes of welfare inclusion and participation of migrants. A shared experience, however, is that large parts of the migrant populations in each country belong to the most disadvantaged groups in terms of access to the labour market, occupational positions and income, educational achievement, housing and health. European welfare states are, however, seen - to a varying extent as institutions that should provide all individuals living permanently on their territory with the means to overcome disadvantages and gain access to resources that will allow them to share in a commonly accepted standard of living.

The fact, however, that many immigrants in European welfare states remain disadvantaged compared with the indigenous population provides the 
basis for assumptions that this may be due to unequal treatment - quite a challenge for European welfare states, which claim to be guided by constitutionally embedded universalism and equal and non-discriminatory treatment. Since one of the effects of immigration is cultural and ethnic pluralisation and the formation of ethnic minorities, it is proclaimed that social disadvantages and inequality may well be the outcome of cultural or ethnic discrimination built into the structure of national welfare states.

This chapter deals precisely with this question. Are European welfare states and their social policies impregnated by implicit or explicit cultural models, and do they have discriminatory effects on ethnic minorities concerning their access to welfare provisions and social security? In order to answer this question, a number of conceptual clarifications are needed: (a) the introduction of a concept of welfare and welfare states and the related social policies; (b) a clarification of what is meant by cultural models implied in the provisions of welfare states; (c) a definition of minorities; and (d) a discussion if there are systematic structural reasons for the discrimination of ethnic minorities involved in the cultural models implied in welfare states. The argument is developed in four steps:

1. a conceptual understanding of the welfare state is introduced

2. the question is discussed of whether welfare states represent different welfare cultures and if this provides the basis for cultural discrimination, a concept defined in this context

3 . the relationship between migrants and welfare states is analysed in order to clarify whether there are structural reasons for cultural discrimination due to this relationship itself

4. the systematic reason for structural welfare disadvantages experienced by migrants is discussed, and finally it will be concluded that cultural discrimination occurs when welfare states use particularity and cultural differences as an internal principle for the organisation and provision of welfare.

\section{Modern Welfare Systems}

Despite the many political disputes about the appropriate form and extent of social security provided by welfare states, only rarely is the point put in a straightforward way ${ }^{1}$ that the best welfare state would be no welfare state. The reason for this seems to be that social order itself is based on a risky model of social inclusion. With the arrival of modern (world) society, the participation of individuals in society is no longer based on any unitary principle of inclusion. There seems to be so much discussion about and insistence on individual rights of participation and social inclusion precisely because both are not guaranteed but risky or even unlikely. 
The early historical experience of modern society is that there is a high risk of failure of social participation. There was and is no automatic inclusion of individuals in society. ${ }^{2}$ The social conditions of inclusion in modern society, that is, the mode by which individuals become engaged, are defined by the differentiated social systems of society, such as the economy, the law, education or health. If individuals fulfil the functionally specific requirements of these systems (as workers, claimants, pupils or patients, respectively), then they may be included. Individuals are perceived in relation to their relevance to these social systems: everything else is left out of the account. ${ }^{3}$

In reaction to the breakdown of pre-modern stratified orders of inclusion, the modern state has sought to deal with the political mediation of the chances of inclusion and exclusion (Bommes 1999). The modern nation-state is defined by the execution of sovereignty over a territory and a population. This was, right from the start, linked with the emergence of the welfare state (Swaan 1988). By providing chances for participation in the social realms of the economy, law, health or education - that is, as a welfare state - the nation-state created the social preconditions for a process in which former subjects became political citizens. This was a process in which the inclusion of the whole population into the political system as individual citizens, and the claim of political sovereignty over them, could gain political legitimacy and universal validity. The welfare state left behind its former role as a polizey and became the central instance in modern society moderating relations between the principle of universal access ${ }^{4}$ to and inclusion in the social realms of the economy, the law, education, health or politics and the empirical reality of social exclusion.

The effect was that national welfare states became the worldwide institutionalised form of organisation of the political system in world society and, with their emergence, they have evolved as international "thresholds of inequality" (Stichweh 1998). This means that they have provided for the "internal loyalty" of their citizens by a welfare policy that promotes chances for inclusion based on external closure and exclusion. From the beginning, welfare provided by the nation-state had a territorial index. The provisions of welfare states were initially addressing only citizens, that is, those individuals that were accepted by the state as belonging to its own territory. Nation-building in Europe took place as a process by which a population was transformed into a unitary nation, a people (Volk) on a politically defined territory (Koselleck 1992; Brubaker 1992). The nation may have been defined in either ethno-cultural terms (such as Germany) or political terms (such as France), but in the historical context of competitive statebuilding processes in Europe, the common welfare of the people of the nation - as "the community of national citizens" - evolved as the general frame of reference for the state (Bommes 1999). This involved the political claim for not only formal, but also substantial equality for all members of 
the national community, a claim founded on the political form of membership, that is, of citizenship (Marshall 1950).

In a most general sense we may say that national welfare states care for their citizens by trying:

- to open or alleviate access to the relevant social systems (the economy, law, education, family or health) and to reduce the risks of exclusion

- to stabilise these systems and their capacities of inclusion (labour markets, families, education, health, etc.)

- to equip individuals to fulfil the conditions for social participation

- to compensate for the social consequences of failing access.

In order to achieve these objectives, states basically rely on law as a means of assigning rights and duties, the political redistribution of money and the symbolic dimension of civic duties. The result of these efforts of states is their highly differentiated welfare infrastructures, involving social security systems dealing with the modern core risks of accident, disease, age and unemployment, social benefits for families, programmes to increase access to education, social benefit payments for the long-term excluded and poor and various public provisions of social services, etc.

National welfare states differ tremendously, especially in Europe, and it seems that this will remain true in the near future, even with the progression of globalisation and European integration and some, although limited, processes of model mixing and assimilation (Obinger et al. 2006). This difference is a result of the various histories of state building by European nation-states, and their welfare structures are the outcome of the accumulated political decisions in a history of designing welfare in nationally specific ways. It is, however, possible to build groups of welfare states by categorising them as different types. According to Esping-Andersen (1990) we find three such types: the liberal, the conservative and the social democratic type of welfare state. Welfare states differ according to this model concerning:

- their extent of de-commodification, that is, the extent to which income and social security is made dependent on participation in the labour market

- the role and amount of residual spending, that is, national assistance as a percentage of social spending

- their redistributive aims and capacity

- their corporatist structure, that is, the differentiation of social security systems according to different occupational and status groups

- the amount of private spending for health and pension systems

- their conceptual assumption about the main provider of welfare, that is, the market, the family or the state. 
Along these lines, welfare states vary largely according to their guidance by different welfare orientations, which can be distinguished as individualistic versus corporatist versus universalist. Examples of the liberal individualistic type are the UK and the United States; the conservative-corporatist type Germany, Austria, Italy and (less so) France; and of the social democratic-universalist type, the Scandinavian countries, especially Sweden and Denmark (Esping-Andersen 1990; Schmid 2002; Opielka 2004). ${ }^{5}$ During the last ten or fifteen years there have been extensive discussions about the adaptive capacity of these different types of welfare state to cope with new constellations as a consequence of the challenges of globalisation. ${ }^{6}$

\section{Welfare Cultures - the Basis of Cultural Discrimination?}

To what extent do different welfare state types also represent different welfare cultures? The answer to this question is evidently relevant for the guiding question of this chapter: whether or not welfare states tend to discriminate migrants or ethnic minorities, and if this is due to cultural models underlying their social policies and infrastructure of welfare provision. In this context, cultural discrimination would refer to social practices that use cultural (or ethnic) differences, implicitly or explicitly, as differentiating organising principles; these regulate the access to social rights and the provision of welfare linked with these rights in a way that systematically causes serious advantages for certain parts of the population and serious disadvantages for others, especially migrants or minorities, concerning their social welfare.

In order to answer this question, it is necessary to distinguish between discrimination that may affect ethnic minorities due to other reasons (we will return to this point below) and that due to cultural models inscribed in the welfare state infrastructures themselves. This is relevant since welfare states in Europe are constitutionally embedded states and claim to follow the rules of equal treatment and non-discrimination for reasons of gender, descent, race, language, origin, beliefs, political or religious views, that is, of non-discrimination also for cultural reasons.

It is obvious that the bundles of organisations, regulations and institutions referred to as welfare states are deeply culturally impregnated. Conceptions of security and insecurity, assumptions about responsibilities for the provision of welfare, the limits of welfare and the extent of individual self-responsibility are contingent and not self-evident. There are always alternative ways and it is certainly possible to organise welfare differently - at least in principle. This becomes evident from the comparison of different types of welfare states. Each of them is based on assumptions about what states should do and to what extent they should intervene, about the meaning and foundations of freedom, about the main institutions and 
foundations of society, etc. Different welfare states are therefore centred around those institutions in different ways:

- individual freedom in markets (liberty and private welfare, liberal individualistic welfare states)

- families/communities (reproduction of the communitarian foundations of society, conservative-corporatist welfare states)

- the state (social equality in labour market society, social democraticuniversalist welfare states).

The outcome is fairly different welfare cultures in each of these states. But this insight does not get very far concerning the answer to the question if, and to what extent, national welfare states also care in a non-discriminatory and more specifically, culturally non-discriminatory manner for migrants or ethnic minorities.

Different welfare models are certainly contested, but this does not immediately imply discrimination of minorities for several reasons: in democratic states, those models are principally the outcome of democratic decision-making processes and embedded in universalistic liberal constitutions that strongly restrict any option of open discrimination. Many welfare programmes include all individuals in the same way and modes of privileging or de-privileging are usually legitimised by the effort to compensate for structural or historical disadvantages, that is, positive or negative discrimination guided by universal criteria. In other words: even restrictive welfare models like liberal welfare states may be criticised for their limited effort to protect the poor - but this affects all individuals living in these countries in the same way if they experience poverty. And if welfare programmes and organisational practices contradict the rules of equal treatment, there is a good chance of de-legitimising these models. ${ }^{7}$ A first conclusion may therefore be that there are good reasons to assume that modern welfare states embedded in universalistic liberal constitutions are built in such a way that provides some strong barriers against discrimination of any kind. But this seems to be too easy an answer in the light of complaints of many minorities, who experience not only general, but particularly cultural discrimination.

\section{Is Cultural Discrimination Inscribed in the Structural Relation between Migrants and European Welfare States?}

In order to approach the question of potential discrimination of migrants or minorities on cultural grounds a distinction needs to be made between allochthonic and autochthonic minorities, that is, minorities resulting from processes of migration on the one hand, and minorities who are constituted 
historically in the process of nation-state building on the other. The following text concentrates on migrant minorities.

Migrants in Europe after the Second World War differ from autochthonic minorities since they entered complete nation-states with already existing institutions. ${ }^{8}$ International migration means geographical mobility in search of chances for social inclusion (Bommes 1999). It implies the readiness to adapt to the social conditions existing in the destination countries, especially as regards markets, legal and political systems, education, health, mass media, the public and religion. ${ }^{9}$ Autochthonic minorities are the result of historical state building processes. Their political and cultural rights are the outcome of political struggles concerning the extent of autonomy of those minorities (Therborn 1995).

In order to understand the position of migrants in welfare states and to tackle the question of potential cultural discrimination, we need to clarify some of the structural specificities of the relation between international migrants and national welfare states. It will be demonstrated (see points A to $\mathrm{G}$ below) that, in a peculiar way, European national welfare states prove to be inclusive and non-discriminatory for long-term resident migrants precisely because of their legal embeddedness, even if they have emerged as institutions of closure and thresholds of inequality for outsiders:

$A$ The provisions of welfare states initially only addressed citizens, that is, those individuals that were accepted by the state as belonging to its own territory. The implication of this was and is, "the institutionalisation of a threshold of inequality' aiming to give privileges to existing citizens and to exclude outsiders from these privileges (see above). Part of the institutionalisation and establishment of national welfare states since the late 19th century was a "history of closure" - this has not been the case since the middle of the 1970s and has been increasingly challenged by various globalisation processes.

$B$ Generally speaking, international migration is an outcome of the expectation of the institutionalised form of mobility in 'modern world society', that is, to move where relevant social resources for an autonomous life are accessible. International migration means precisely the effort of realising the chance of a better life by means of geographical mobility. This implies no structural problem per se for those social systems primarily affected, such as labour markets, education systems or families. ${ }^{10}$ Nevertheless, most international migration is confronted with all kinds of legal and political intervention.

$C$ The structural basis for such intervention is the organisational form of politics in modern society - the nation-state. Political and legal intervention in international migration happens regularly and not just by historical chance. The intervention articulates an 'internal structural contradiction' of world society: the permanent production of motives for international migration - due mainly to the demand of labour markets and the options of 
education systems, the institutionalisation of the nuclear family, the worldwide communication of options by the mass media and the accessibility of transport (just to name the most important factors) - and the constant political effort to restrict these migrations ${ }^{11}$ and to reduce motives for migration due to the specific structure of the political system, that is, its internal segmentary differentiation into nation-states (Stichweh 1998).

$D$ One strong implication of the worldwide institutionalisation of national welfare states has been the partition of the world population into 'state populations' (Halfmann 2005). International migrations have always questioned this division by crossing borders in search of chances of social participation. The reactions of nation-states to these migrations are mediated by the two constitutive dimensions defining the relation between states and their populations. There are: (a) the dimension of loyalty, referring to the requirement of obedience to the political decisions of states by citizens and all other people residing on the territory, as a fundamental condition for the reproduction of state sovereignty; and (b) the dimension of 'provision', which refers to the obligation of the state to provide legal, political and social security in exchange for loyalty, summarised in the concept of the welfare state (Marshall 1950). Nearly all political modes of regulating international migration are guided by aspects concerning one or both of these aspects of loyalty and provision (Bommes 1999). Current examples are, on the one hand, the public linkages between migration and terrorism in recent years, thereby questioning the loyalty of migrants and, on the other, the frequent debates in nearly all European welfare states concerning the effects of international migration on the capacity of welfare-state provision (Bade \& Bommes 2004).

$E$ International migrations have therefore never been just the unwanted outcome of societal mobility structures, but have rather, to a large extent, been induced by the nation-states themselves (Bade 2003). States allow for international migration depending on their expectation that it will contribute to economic growth, the reduction of structural supply deficiencies in labour markets, the compensation of demographic problems, etc. Europe is a case in point, where most of the northern and western states have 'actively attracted' migrants from the 1950 s until the middle of the $1970 \mathrm{~s}^{12}$ This has been the take-off point for the emergence of Europe as one of the main regions of immigration in the world, and many of the current immigration flows in Europe are still, to a large extent, structurally based on these early immigrations (Bade 2003; Castles \& Miller 2003).

$F \quad$ The emergence of Europe as one of the main regions of immigration in the world was an unintended political outcome of the policies of different national welfare states in Europe. But these states, coming from different starting points and building Europe from the 1950s on, have gone through an uneven process of mutual adaptation linked with a successive 'normalisation' of immigration and settlement processes. They had to 
realise that most of the immigrants of the 1950s, 1960s and 1970s had gained access to civil and social rights, which had formerly been seen as privileges reserved for citizens (Brubaker 1989; Hollifield 1992; Soysal 1994), and in this way had become 'denizens' (Hammar 1989). The irreversibility of this constellation had become clear by 1989 , at the latest. During the 1990s, most European states normalised their 'denizens' by offering easier legal access to naturalisation and citizenship (Weinbach 2005). In parallel with this, they harmonised and tightened their different migration regimes concerning selection and control of access to the European territory. It needs to be noted, however, that until the 1990s, European national welfare states were rather inclusive, even if unintentionally so, and the surprising result was that the architecture of constitutionally embedded welfare states provided access to social rights even for noncitizens. The longer migrants resided in the country of destination, the more rights they were able to accumulate (Bommes 1997; Joppke 1998), and in this way, it was the architecture of European welfare states that proved to be non-discriminatory, even if this was not always appreciated politically.

$G$ The reverse of welfare inclusion and the alleviation of legal naturalisation opportunities has been both the increase of migration control and the closure of Europe on the one hand and, seemingly paradoxically, the introduction of regular integration programmes for migrants on the other. These integration programmes ${ }^{13}$ are part of the reorganisation of migration and integration policies relating to recent reforms of welfare states in Europe that fall under the heading of the 'activating welfare state' (EspingAndersen 2002). 'Social integration' refers to a mode of addressing migrants who are residing legally in a country, which puts them in a similar relationship to the welfare state as all other clients. 'Activation' means a reorganisation of the relation between the welfare state and welfare receivers, in a way that welfare rights are made more and more dependent on duties and on means testing.

All receivers of welfare are confronted with the expectation that they must adjust their way of life to self-responsibility and employment, in order to become independent of welfare support as far as possible. This adjustment particularly affects the less competitive sections of the population, independent of their nationality. Therefore, the difference between citizens and foreigners loses even more of its former relevance. From the perspective of welfare states who have, since the 1990s, reorganised their welfare programmes by reducing the capacity for provision, national citizenship loses much of its capacity to preserve social privileges, since all clients are treated equally, and treated only as being potentially competitive or noncompetitive (Bommes 2003). All individuals are expected to strive for competitiveness and, from this perspective, options of migration and naturalisation are made dependent on the effort of 'social integration', which 
should be achieved by migrants themselves. The report of the former Independent Commission for Migration in Germany, headed by Rita Süßmuth, stated: 'Integration is a social process that involves everyone in any society. Willingness to integrate is indispensable: it manifests itself if each individual takes the initiative to make an effort towards social integration. This applies to the domestic population and to immigrants alike' (Süßmuth Commission 2001: 196). There remains, however, a decisive difference between citizens and foreign migrants: the latter are judged by their potential risk of 'integration failure', and on this basis they may either be denied access to the territory at all $^{14}$ or their residence status may be restricted. ${ }^{15}$ In other words, the acquirement of citizenship, as a full political inclusion, is made conditional upon the ability and willingness to integrate socially, that is, to have access to the economic, cultural and social competencies and resources necessary for autonomous participation in the central realms of society, especially the labour market and education. Seen from the perspective of activating welfare states, the ability of integration needs to be created and enforced among those migrants already residing legally on the territory and among those constantly (and unavoidably) arriving, based on the principle of 'rights and duties', that is, offering support and demanding the active effort of social integration.

One surprising result of the migration policies of 'activating welfare states' in Europe, that is, the combination of increasing external control with internal social integration policies, is the continuously diminishing relevance of the difference in social rights between citizens and legally resident foreign migrants. The outcome of the recent reforms of welfare states, trying to cope with their reduced capacity of provision in the context of globalisation since the 1990s, has not been an increasing exclusion of migrants, but rather a further levelling of the difference between foreign migrants and citizens, the former, generally speaking, on a lower level of welfare provision.

$H$ However, one may be tempted to suspect that there is an element of cultural discrimination implied in this policy, since the stress on 'social integration' seems to imply the 'return of assimilation' (Brubaker 2001) - an enforced cultural assimilation policy. But this return would be misread if it were understood as the re-invention of former assimilation policies, which had been characteristic during the period of nation-state building in Europe up to the middle of the 20th century (Therborn 1995). The focus of social integration policies is the active mobilisation of individuals in order to orient them to the conditions of inclusion, primarily into labour markets and education. This does not imply assimilation in terms of cultural homogenisation. Obligatory language courses and citizenship classes, the core elements of many integration programmes, do not question cultural and linguistic pluralisation, ${ }^{16}$ even if they are not based on multiculturalist policies aiming to support ethnic minorities and their cultures. ${ }^{17}$ The obligation 
to learn the language is based on the expectation that successful inclusion in education and labour markets will require some knowledge of the local language of intercourse. It is not based on any 'thick notion' of language interpreted as the foundation of the national community (Maas 2007). Instead, activating welfare states seem rather to be 'deregulating' cultural orientations and identities, corresponding to the general tendency to replace the classical promise of the national welfare state, as described by T.H. Marshall - to offer each citizen full membership in the national community ${ }^{18}$ - by the reduced promise of resources for basic needs. Competitiveness in terms of education and labour market success provides the basis for legitimate claims on the income and supportive politics of the state, whereas the reference to citizenship and national belonging provides less and less legitimacy for such claims (Bommes 2003); in other words, the semantics of national solidarity has lost much of its meaning.

To sum up: the analysis of the structural relation between national welfare states and international migrants and the review of the position of migrants in European welfare states leads to the following conclusions:

A. National welfare states create international 'thresholds of inequality' through which they aim to privilege their citizens in comparison to foreigners/migrants. This is one foundation for the insistence of states to maintain control over access to their territory. ${ }^{19}$ The current regimes of European welfare states are even trying to increase this control over access in relation to all categories of unwanted migrants. ${ }^{20}$

B. These same welfare states have turned out to be rather inclusive in relation to their major migrant categories since the Second World War. This inclusiveness was not the original intention, but was a structural outcome of the way welfare functions in constitutionally embedded liberal states. The 'thresholds of inequality' cannot be kept up internally on the basis of the difference between citizens and foreigners.

C. The effect of welfare state reforms under the heading of activation since the 1990 s, as a consequence of their reduced capacity of welfare provision, has been a further levelling of the status of citizens and migrants with legal residence status, as clients of the welfare state. The main criterion for the position of individuals in welfare states is competitiveness, and national belonging is losing relevance.

\section{Structural Reasons for Disadvantages of Migrants in Welfare States}

In order to answer the question posed in this chapter, whether welfare states tend to discriminate against minorities in cultural terms, two tasks remain to be solved: firstly, it needs to be clarified whether there are 
structural and not only cultural reasons why migrants are faced with higher risks of inequality in terms of welfare provision due to the very fact of migration itself, which may place them in a weaker position than that of lifelong citizens. It will be argued that this is due to the fact that the relation between welfare states and their citizens is conceptualised as a lifelong relationship. The risk of failing to be included in modern society is addressed by welfare programmes, which accompany individuals from early childhood onwards, through to pension age and death - with some effects on the position of migrants in welfare states. Secondly, it may be suspected that structurally based cultural discrimination can be found in welfare states, less because of their specific cultural models of welfare (see paragraph B above), but rather that discrimination for cultural reasons may be found in welfare states which use particularity and cultural differences as an internal principle for the organisation and provision of welfare.

\section{a Welfare, Life Course Regimes and the Position of Migrants}

Welfare states organise their welfare programmes around the 'biography' and career of individuals from their birth and early childhood onwards until their death. ${ }^{21}$ The institutionalisation of the modern 'life course regime' has been the result of the emergence of welfare states. The life course can be understood as complex social rules that order the time dimension of an individual life, viewed as a sequential programme (Kohli 1986). 'Biography' and 'career', both of which are central elements of the social concept of a life course, are historically formed by the interplay of the modern labour market recruiting individuals and the welfare state establishing social preconditions for the possibility to find and recruit individuals with an expectable life course. The introduction of social insurance schemes had the effect of organising the temporal accumulation of social entitlements around the employment of individuals in organisations. This accumulation therefore depends, to a large extent, on the duration of employment, changes in the conditions of employment and dismissal, the institutionalisation of public education and the provision of family and education allowances.

The implementation of welfare-state measures can be understood as the successive introduction of the structural elements which make up the institutionalisation of the life course. Life becomes socially conceptualised as a sequential programme, partitioned into three general stages: childhood/education, foundation of family and working life, and retirement. Welfare state measures orient individuals towards the structure of a life cycle and the expectation of a career. $^{22}$ The core institutions of the welfare state - the family, education, unemployment, illness, accidents, retirement - are structured in a way that implies the expectation that individuals are equipped and willing to prepare themselves for a biographically ordered sequence of 
inclusions in different social realms and organisations, especially the education system and labour market. The institutionalisation of the life course and its variations in different welfare states can be taken to be the result of the specific historical formation of the relation between each state and its citizens. It is obvious, however, that the relation between state and its citizens is conceptualised in this way as a lifelong relationship.

The constitution of biographies and their regulation by the welfare state make it very likely that the biographies of migrants will deviate from the standard pattern. Deviation means that their life courses and biographies do not fulfil the institutionalised expectations of normality valid in each welfare state. Biographies and related careers refer to the accumulation of chances for structural participation. International migrants are presumed to be poor or deprived, since it cannot be assumed that they have built their careers with the required elements. Consequently, those things that under 'normal conditions' are treated as given can no longer be presupposed. This becomes obvious if one looks at certain common deviations of migrants in three biographically important areas: education, labour and participation in pension schemes.

\section{Education}

Migrant children have access to schools in many countries even when they do not have a residence permit. The normal expectations of education systems rely on the assumption that families of children are settled. But migrant children (with or without legal status) may not speak the official language and, in this way, question institutionalised assumptions about normal socialisation processes, as well as linguistic and cultural competencies, as central preconditions for the ability to learn something. Moreover, careers of migrant children that were built at school in their countries of origin may not be accepted by the education system in the destination country. This may block important paths of educational success and increase the likelihood of failure. This does not immediately justify easy assumptions about cultural discrimination, since immigrant children certainly need to learn the language of the destination country ${ }^{23}$ and have to face the challenge of second-language acquisition. It refers, however, to two serious problems: their potential comparative disadvantage of competition in relation to the indigenous pupils; and that schools use cultural and linguistic backgrounds as a means of discrimination because this allows them to solve everyday problems of organising education, to avoid adequate adaptation to the challenges of education linked with ongoing immigration and to take educational decisions (Gomolla \& Radtke 2004).

Of course, this type of potential cultural discrimination has no structural foundation in the principles of modern education systems of welfare states, since they are based on universalism, that is, the right to education for every child; but rather - and in practical and empirical terms this may be 
highly relevant ${ }^{24}$ - in the capability of the education system's everyday routines to handle the challenges of migration and its institutional barriers to carrying out the necessary adaptations to the conditions of immigration. It becomes, however, a case of structurally based cultural discrimination if education systems fail to adapt to immigration, which involves the task of educating bilingual or even multilingual children, socialised in families that use a language other than the language of the destination country on a daily basis. In other words, if the institutionalised assumptions about normal socialisation processes, including linguistic and cultural competencies, as central preconditions for the ability to learn something are not revised with respect to immigrants, even second- or third-generation children will remain affected, in a culturally discriminatory manner, by institutionalised expectations concerning the normality or deviation of individual biographies.

\section{Employment}

Migrants are less likely to be able to offer socially established biographies and careers of education and work. This excludes them from competing in large segments of the labour market. ${ }^{25}$ It should be noted, however, that the absence of careers and related social claims was, in many respects, the precondition for the immigration of labour to western European countries during the post-war period, and this is still the case today. For many migrants, it is paradoxically the absence of a career at the start that provides chances for social inclusion in those labour market segments in need of unqualified workers. The same holds true for much illegal immigration and explains its ongoing dynamics (Bommes 2006).

\section{Retirement}

Migrants can usually obtain welfare entitlements even if they are not citizens. Older migrants, however, are likely to have low pension incomes since many have not been included in pension insurance funds long enough to accumulate adequate entitlements. ${ }^{26}$ For this reason, it is likely that many may have to rely on public assistance.

These three brief examples show the ways in which migrant biographies may deviate from the expectations guaranteed by welfare states. The social consequences of this cannot be extrapolated theoretically. Deviation and its consequences depend upon the various kinds of expectations of normality supported by different types of welfare state. Moreover, immigration takes different forms in different countries and migrants have varying legal and welfare entitlements linked to their immigration path. In the context of this chapter, they serve to demonstrate that migrants are usually faced with a higher risk of exclusion and reduced access to welfare provision, due to their varying life course regimes, which deviate from that institutionalised in welfare states. If we assume that, for demographic and other reasons, 
immigration will be an enduring phenomenon in Europe, it is worth stressing that it may be the time dimension, less than the cultural dimension, which proves to be relevant for the discriminatory effects of welfare states; at least if it cannot be presupposed that a relevant and potentially increasing section of the population in Europe - migrants - has a lifelong relationship with the welfare state, an implicit assumption built into their organisational structure.

\section{b Cultural Discrimination as a Potential Effect of Corporatist Welfare}

Does this allow the conclusion that cultural discrimination of migrants, which may be found in school systems, employment ${ }^{27}$ or housing markets, among others, has no structural foundation in the design of modern welfare states themselves and that, on the whole, cultural discrimination proves to be irrelevant in welfare states? It seems that structurally based cultural discrimination can be found in welfare states less because of their general cultural models of welfare (see section 2 above), but because some welfare states use particularity and cultural differences as internal principles for the organisation and provision of welfare. This has some surprising effects, depending on the way in which these differences are made relevant. Two complementary examples, which demonstrate this point, are the Netherlands and Germany.

The Netherlands has been famous for a multicultural policy based on the early recognition of ethnic minorities, which was seen as the outcome of post-colonial and labour migration in the 1960s and 1970s. The political aim of this policy has been to provide social inclusion and equality for migrants by means of a policy that addressed ethnic communities, while assuming that social inclusion and equality are the effective and efficient mediators of social opportunities for migrants. The model for this approach was 'pillarisation', that is, the building of state and society on top of the relevant societal pillars (Catholics, Protestants, liberal) allowing each of them to create their own institutions. Ethnic minority policy was conceptualised in this tradition, allowing immigrants to develop their own institutions (Entzinger 1998). Pillarisation had, however, already lost much of its relevance for the indigenous population due to the expansion and modernisation of the Dutch welfare state during the 1960s and 1970s. The ironic effect of this welfare policy for migrants based on the cultural recognition of minorities was that it effectively excluded large parts of the immigrant population from the labour market, at the precise moment when the Dutch 'employment miracle' of the 1990s attracted much attention in a Europe struggling with high unemployment rates. This caused a policy shift away from the ethnic minority approach to a policy of social integration addressing individual migrants and aiming to improve their labour-market 
performance. It turned out that the very European country that had long been referred to as having a model example of a successful multicultural policy based on its acceptance of the outcomes of immigration (the emergence of ethnic minorities) not only did much worse in terms of labour market inclusion of their immigrants, it also allowed for the far-reaching cultural isolation of some sections of immigrants, due to the reliance on the pillarisation model. The unintended outcome of 'positive cultural and ethnic discrimination' has been structural discrimination, that is, that large parts of the immigrant population, especially those of Moroccan and Turkish origin, found only restricted access to the labour market and failed in educational terms (Koopmans 2003; Böcker \& Thränhardt 2003).

The surprising result of recent comparisons between the Netherlands and Germany has been that immigrants in Germany, a country long reluctant to accept the fact of immigration, have done much better in terms of employment and social security. Seen in this way, the organisational model of the German welfare state proved to be much more inclusive than the Dutch model (Böcker \& Thränhardt 2003). Nevertheless, even after the reform of the naturalisation law in 2000 and the recent implementation of an immigration law in 2005, signifying political acceptance of being a factual immigration country, Germany turns out to be an interesting case of a welfare state with some potential for 'cultural discrimination'. This is not due to any 'minority policy' but to the organisational structure of the welfare state itself. Germany has been described as a conservative-corporatist welfare state. An important element of this model is the so-called 'principle of subsidiarity', that is, the secondary liability of the state, which takes over responsibility only in cases where welfare cannot be provided by the relevant responsible groups and institutions (such as the family and religious or non-religious communities). The effect of this has been that large parts of the German welfare system are organised by Protestant and Catholic churches and religious and secular charities, which are subsidised by the state. ${ }^{28}$ Kindergartens, schools, hospitals and old people's homes are run, to a large extent, by the Christian churches or religious charities. This has discriminatory effects in cultural terms in two directions.

Firstly, non-Christian and especially Muslim migrants often see themselves confronted with welfare infrastructures deeply impregnated by Christian traditions, due to the strong position of the Christian churches in the German state (Fetzer \& Soper 2005). This does not mean that Christian churches or charities and the organisations run by them exclude migrants or explicitly discriminate against migrants. On the contrary, historically, the churches have been at the forefront in defending migrants against discrimination and arguing for the expansion of their civil, political and social rights. Muslim migrants in particular, however, struggle to have the same rights as other religious communities - with some success. A current example is the serious effort to institutionalise regular religious education of 
Muslim children in schools, by teachers trained in German universities, supervised jointly by officially recognised Muslim communities and the German authorities. ${ }^{29}$ It will certainly be one of the major future topics, not only in Germany, to which extent Muslims should have the same rights as other religious communities. One implication of this is that, in the light of the arrival of Islam in Europe, many European states will need to readjust their historical compromises concerning the differentiation between politics, law and religion (Fetzer \& Soper 2005; Klausen 2005; Søvik 2006).

Secondly, parents of non-immigrant children tend to send their children to Christian schools in order to avoid schools with high numbers of immigrant children, especially those of Turkish origin. This 'white flight' is, to a certain extent, based on the limited secularisation of the education system. This type of educational segregation, which is an effect of the behaviour of the educated middle classes, may well be understood as cultural discrimination, due to the specific structural design of the German welfare state and the role of religion. ${ }^{30}$ To sum up: cultural discrimination seems to become relevant not because of any open or hidden discrimination directly affecting migrants, but because of the privileged position of religious communities, due to their historical role in the state building process and the emergence of the welfare state.

\section{Conclusion}

This chapter has discussed the question of whether the cultural models of welfare inscribed in welfare states have a discriminatory effect on ethnic minorities with respect to their access to welfare provision and social security. Based on the fact that migrant minorities in many European countries experience disadvantages and have fewer social security provisions than the indigenous population, it is often assumed that this is due to cultural discrimination. The argument here is developed in three steps and tests the assumption of cultural discrimination by looking at the cultural models of welfare inscribed in European welfare states and by analysing the relation between national welfare states and migrants. After clarifying some structural and functional specificities of modern welfare states, it is argued that the fact that European welfare states are based on different cultural models of welfare does not prove systematic cultural discrimination. The latter includes social practices that use cultural (or ethnic) differences, implicitly or explicitly, as differentiating organising principles, which regulate access to social rights and the provision of welfare linked with these rights in a way that brings advantages for certain parts of the population and causes serious disadvantages for others, such as migrants, with regard to their social welfare. As long as the different cultural models of welfare 
established in European welfare states are applied equally to the long-term resident population of a state, this provides no basis for the assumption that migrant minorities are culturally discriminated against, especially since constitutionally embedded European welfare states operate based on universalistic rules.

The structural reason for the weaker position of migrants in welfare states is instead to be found in the way welfare operates, that is, centred around the biography of individuals via the institutionalisation of life course regimes. Since the provision of welfare is based on the assumption of a lifelong relationship between the state and welfare receivers, migrants tend to be disadvantaged because of their deviating life course and timelimited relationship with the country of destination. There is, however, cultural discrimination to be found in those welfare states that use particularity and cultural differences in a corporatist manner as internal principles for the organisation and provision of welfare, be it via welfare policies aiming to support ethnic minorities, or welfare policies based on the 'principle of subsidiarity'.

What conclusions can be drawn from this analysis? Migrants in Europe experience, to a large extent, social disadvantages and restricted access to the important spheres of life such as the labour market, education, health or housing. Events like riots in France and Britain, the murder of Theo van Gogh in the Netherlands, the involvement of young immigrants in terrorism in Britain, Germany or Spain, or less dramatically, the increase of social segregation in many countries, all indicate that increasing social inequalities and resulting social stratification are linked with severe consequences, which are debated all over Europe under the headings of failing social integration and endangered social cohesion. It seems, however, that the social processes underlying these unintended outcomes are, to a large extent, not well understood, if they are ascribed to processes of cultural discrimination embedded in the structures of European welfare states. This result of the analysis may be a relief in normative terms - however, it leaves us with the unresolved constitutive puzzle of modern society - its reflexive concern with problems of inequality and social inclusion precisely resulting from its structural potential to produce and to allow for enormous differences, inequalities and exclusions.

\section{Notes}

I Except for many economists, who believe in the superior rationality of markets but seldom have to take political responsibility for any seriously proposed model of Platonism.

2 The concepts of inclusion and exclusion are used here in a rather technical manner, implying no normative assumptions: Inclusion formally speaking is the way in which individuals are addressed in social contexts as relevant for actually ongoing 
social processes; exclusion correspondingly refers to the irrelevance of individuals and this does not always indicate a 'social problem', e.g. the irrelevance of an individual for the health system means the individual is healthy and thus not a relevant case for a doctor or hospital.

3 This means, on the other hand, that social inclusion in modern society presupposes the exclusion of individuals as 'totalities' from society in the sense that they are not predefined by social bonds or some principle of belonging (Luhmann 1989). Instead, individuals become socially defined by their personal histories of inclusion and exclusion in different social realms, i.e. their careers and biographies. This is the basic reason for the central importance ascribed to biographies and careers in modern society - formerly unknown - and for the increasing awareness that the success of welfare or social policies depends to a large extent on their capacities to allow individuals from childhood onwards to build up a career (Esping-Andersen 2002).

4 Universalism of inclusion in modern society means that nobody should be excluded from claiming economic, legal or educational provisions if he or she can fulfil the social preconditions for any of these claims (Luhmann i989). For example, one can participate in education if one is perceived as educable, one can participate in the economy if one finds access to monetary means, and one can participate in law if one knows how to act on behalf of one's rights. At the same time, none of these necessarily imply that inclusion always empirically succeeds - on the contrary it rather often fails. But the valid institutionalisation of social expectations like the universalism of inclusion provides the basis for the perception of this failure as a problem in need of remedy, e.g. by means of welfare policy.

5 This modelling has been criticised in many respects. Some argue that there is a fourth type in Europe, the so-called Mediterranean type (Ferrera I998); some question the empirical applicability of the model (Albers 2000). For a discussion see also Kaufmann (2004); we cannot, however, go into any detail here.

6 See Esping-Andersen I996, 2002; Ganßmann \& Haas I999; Goodin et al. I999; Alber 2000; Fligstein 2000; Kaufmann 2003; Leibfried \& Zürn 2005. On a most general level, the outcome of this discussion is that those welfare states that do best manage to combine access to labour and the provision of welfare instead of providing welfare as a substitute for labour - a problem mainly for the conservative-corporatist type of welfare states. The recent shift to so-called activating welfare policies in many countries is a reaction to these problems. The integration policies in many countries addressing migrants belong in this context.

7 Feminism and the institutionalisation of gender mainstreaming are striking examples.

8 This argument certainly needs more explanation. It is useful, however, in order to note the main difference between migration in Europe and migration in classical immigration countries. These countries, such as Canada, the USA, Australia or New Zealand, have used immigration as a mechanism for state building, i.e. creating their state populations by means of immigration. This is still present in many of their current ways of dealing with immigration, which still differ to a large extent from European migration policies. On the other hand, post-colonialism has been a defining frame for the handling of migration in countries like the Netherlands, the UK or France. And in Germany, the immigration of ethnic Germans, one major immigration strand accompanying most of its post-war history (Bade \& Oltmer 2003), was, until 1989 , due to a turbulent and unfinished state building process.

9 A clarification in order to avoid any misunderstanding: They do not have to adapt to any of the dominant or minority religions but to the institutionalised state of societal 
differentiation, i.e. the differentiation between religion and the other societal realms, especially politics, law, education, health, the mass media and the economy.

Geographical mobility inside of nation-states for reasons of employment, family reunion or education is not counted as migration and those involved are normally not treated as migrants.

II See Castles \& Miller (2003). The Global Commission Report can be read as an effort to overcome this basic contradiction in the time dimension, arguing that international migration will be to the benefit of all 'in the long run' - although it is faced, at present, with all kinds of 'short-term' barriers.

I2 The most recent southern immigration countries (Italy, Spain, Portugal and Greece) seem to be attracting migrants in a rather clandestine manner, on the one hand, formally adapting their migration regimes to the existing EU framework and allowing, on the other hand, constant flows of irregular migrants by means of recurrent legalisation programmes (for Italy, see Finotelli 2006).

I3 The integration programmes referred to can be found in many countries since the late I990s, among others the Netherlands, Sweden, France and Germany. See Michalowski 2006; Schönwälder, Söhn \& Michalowski 2005.

I4 It seems that control of migration and social integration are two key elements of current migration and integration policies in Europe, i.e. the effort to define and to enforce the difference between the wanted and the unwanted migrants. This implies access to opportunities for those migrants seen as potentially competitive (e.g. highly qualified migrants, entrepreneurs and students) and restrictions as far as possible for unavoidable migration based on family reunification and humanitarian reasons. In this same context, the controlling capacities of single states and the EU are constantly increased.

I5 Countries like France, the Netherlands and Germany link non-participation of migrants in obligatory 'integration courses' with sanctions concerning their status of residence (Michalowski 2006). It is obvious that states cannot threaten their citizens in the same way, which demonstrates that citizenship, once acquired, remains an undeniable social status protecting against deportation.

I6 'Public integration panics' as were observed after the murder of Theo van Gogh in the Netherlands, the riots in France and the dispute on the Mohammed caricatures, seemed to indicate quite some effort to return to more substantial assimilationist and identity policies. In the end, it turns out that liberal states cannot easily suspend cultural and linguistic pluralisation, since it proves to be impossible to identify and agree on guiding values and norms beyond the basic principles of freedom and equality which allow for what is seen as problematic and in need of restrictions, i.e. cultural and linguistic pluralisation.

I7 It seems that multiculturalist policies conceptualising ethnic minorities collectively as the main addressees of integration and welfare policies have been a late outcome of the prosperous welfare states of the I960s and I970s; for the Netherlands, see Entzinger (1998).

I8 See Marshall (I950). A classical text of the sociology of the welfare state, it described the institutionalisation of national citizenship in 1949 as the historical emergence of civil, political and social rights. Empirically, Marshall referred to the development in Britain, and interpreted the welfare obligations of the state as the successive, evolutionary realisation of the structural implications of modern national citizenship. 'Citizenship', for him, meant the institutionalisation of the expectation that it is the duty of the modern state to secure social inclusion of all citizens as full members of society and the national community. Clearly, his starting assumption was that the nation-state will be able to control enough resources in order to enforce this 'ideal citizenship'. 
I9 One of the means to maintain control on migrants is the introduction of time-limited access to the territory and labour market based on models of seasonal and contract labour. These types of migrants are more or less effectively excluded from national welfare schemes, and the accumulation of irreversible social rights is linked to a process of stabilisation of their residential status. There is a current debate among EU governments as to whether models of so-called circular migration would allow the advantages of illegal migration to be made use of by avoiding its unwanted effects.

20 There can be no detailed discussion here concerning the potential success of these efforts in the light of illegal migration, increasing globalisation, etc.

2I A more detailed analysis is elaborated in Bommes (2000). It may be stressed, however, that the importance of biography or life course is based on the structural conditions of modern society and its mode of inclusion and exclusion, even if the institutional designs of biographies differ to a certain extent from country to country within Europe.

22 Achievement of a continuous employment career is difficult for quite a number of individuals, thereby weakening their welfare position. Nevertheless, or perhaps even because of this, competition between individuals in labour markets takes the form of diversified careers, i.e. the collection of more and more experience in shorter time periods and in increasingly varied locations.

23 This is not only the implication of their parents' migration decision but also a precondition for their access to education and the labour market.

24 As various comparative studies of the OECD, known under the names of PISA and IGLU, have demonstrated.

25 To the extent that social networks play an important role for the mediation of access to employment, this has serious effects on the labour market chances of the second and third generations, since their parents often cannot act as 'gatekeepers', who mediate in obtaining better paid jobs for their children; see Bommes \& Tacke (2006).

26 Most pension insurance funds in European welfare states make entitlements dependent on the length of time spent on state territory and/or the length of time of employment and contribution (Dörr \& Faist 1997). Because of the difference between pension schemes, this is usually not compensated by the mechanisms of co-ordination and harmonisation established in international social law (Eichenhofer 1994). This underpins the importance of the life-course-oriented relationship between a welfare state and its citizens.

27 Cultural discrimination of migrants in the labour market and in employment has attracted much attention. The basis for this, however, is the structural insecurity problem linked with the recruitment decision, i.e. the decision to select the right individual for employment. This opens up a number of opportunities for discrimination against outsiders applying for jobs and has been the focus of the struggle for gender equality. The structural foundation of this type of discrimination is the mode of operation of organisations based on decision making (Luhmann 2000; Bommes \& Tacke 2006) and not the organisational principles of welfare states.

28 The German Catholic charity 'Caritas' is one of the major employers in Germany.

29 On the history of the struggles over Islamic education in German schools, see Søvik (2006).

30 Similar arguments for other European countries can be found in Klausen (2005). 


\section{Bibliography}

Alber, Jens (2000), 'Sozialstaat und Arbeitsmarkt: produzieren kontinentaleuropäische Wohlfahrtsstaaten typische Beschäftigungsmuster? - gleichzeitig eine Abhandlung über einige Problem komparativer statistischer Analyse', Leviathan 28 (4), pp. 535-570.

Bade, Klaus J. (2003), Migration in European History. Oxford: Blackwell.

Bade, Klaus J. \& Michael Bommes (2004), 'Einleitung', in idem (eds), Migration Integration - Bildung. Grundfragen und Problembereiche (IMIS-Beiträge 23), Osnabrück, p. 7-20.

Bade, Klaus J. \& Jochen Oltmer (2003), Aussiedler: deutsche Einwanderer aus Osteuropa (IMIS-Schriften 8). Göttingen: V\&R unipress.

Böcker, Anita \& Dietrich Thränhardt (2003), 'Erfolge und Mißerfolge der Integration. Deutschland und die Niederlande im Vergleich', in Aus Politik und Zeitgeschichte B 26, 23 June, pp. 3-11.

Bommes, Michael (1997), 'Von >Gastarbeitern` zu Einwanderern: Arbeitsmigration in Niedersachsen', in Klaus J. Bade (ed.), Fremde im Land: Zuwanderung und Eingliederung im Raum Niedersachsen seit dem Zweiten Weltkrieg (IMIS-Schriften, vol. 3). Osnabrück: Universitätsverlag Rasch, pp. 249-322.

Bommes, Michael (1999), Migration und nationaler Wohlfahrtsstaat. Ein differenzierungstheoretischer Entwurf. Opladen/Wiesbaden: Westdeutscher Verlag.

Bommes, Michael (2000), 'National Welfare State, Biography and Migration: Labour Migrants, Ethnic Germans and the Re-Ascription of Welfare State Membership', in idem \& Andrew Geddes (eds), Welfare and Immigration: Challenging the Borders of the Welfare State. London: Routledge, pp. 90-108.

Bommes, Michael (2003), 'The Shrinking Inclusive Capacity of the National Welfare State: International Migration and the Deregulation of Identity Formation', in Grete Brochmann (ed.), The Multicultural Challenge (Comparative Social Research 22). Oslo: Elsevier, pp. 43-67.

Bommes, Michael (2004), Erarbeitung eines operationalen Konzepts zur Einschätzung von Integrationsprozessen und Integrationsmaßnahmen. Gutachten für den Sachverständigenrat für Zuwanderung und Integration, Osnabrück.

Bommes, Michael (2006), 'Illegale Migration in der modernen Gesellschaft - Resultat und Problem der Migrationspolitik europäischer Nationalstaaten', in idem \& Jörg Alt (eds), Illegalität: Grenzen und Möglichkeiten der Migrationspolitik. Wiesbaden: VS Verlag für Sozialwissenschaften, pp. 95-116.

Bommes, Michael \& Veronika Tacke (2006), 'Luhmann's Systems Theory and Network Theory', in David Seidl \& Kai Helge Becker (eds), Niklas Luhmann and Organization Studies. Copenhagen: Copenhagen Business School Press, pp. 282-304.

Brubaker, Rogers (ed.) (1989), Immigration and the Politics of Citizenship in Europe and North America. Lanham/London: Univ. Press of America.

Brubaker, Rogers (1992), Citizenship and Nationhood in France and Germany. Cambridge, MA: Harvard University Press.

Brubaker, Rogers (2001), 'The Return of Assimilation? Changing Perspectives on Immigration and its Sequels in France, Germany and the United States', in Ethnic and Racial Studies 24 (4), pp. 531-548.

Castles, Stephen \& Mark J. Miller (2003), The Age of Migration. Basingstoke: Macmillan.

Faist, Thomas \& Silvia Dörr (1997), 'Institutional Conditions for the Integration of Immigrants in Welfare States: A Comparison of Germany, France, Great Britain, and the Netherlands', European Journal of Political Research 31, pp. 401-426.

Eichenhofer, Eberhard (1994), Internationales Sozialrecht. München: C.H. Beck.

Entzinger, Han (1998), 'Zu einem Modell der Inkorporation von Einwanderern: das Beispiel der Niederlande', in Michael Bommes \& Jost Halfmann (eds), Migration in nationalen 
Wohlfahrtsstaaten. Theoretische und vergleichende Untersuchungen. Osnabrück: Universitätsverlag Rasch, pp. 105-122.

Esping-Andersen, Gøsta (1990), The Three Worlds of Welfare Capitalism. Cambridge: Polity Press.

Esping-Andersen, Gøsta (ed.) (1996), Welfare States in Transition: National Adaptations in Global Economies. London: Russell Sage Foundation.

Esping-Andersen, Gøsta (ed.) (2002), 'Towards the Good Society, Once Again?' in Why We Need a New Welfare State. Oxford: Oxford University Press, pp. 1-26.

Ferrera, Maurizio (1998), "The Four "Social Europes": Between Universalism and Selectivity', in Martin Rhodes \& Yves Meny (eds), The Future of European Welfare: A New Social Contract? London/New York: Macmillan, St. Martin's Press, pp. 79-96.

Fetzer, Joel S. \& J. Christopher Soper (2005), Muslims and the State in Britain, France, and Germany. New York: Cambridge University Press.

Finotelli, Claudia (2006), »Asyl in Deutschland oder >illegal in Italien: Zur funktionalen Äquivalenz entgegengesetzter Einwanderungsregime«. $\mathrm{PhD}$ dissertation, University of Münster.

Fligstein, Neil (2000), 'Verursacht Globalisierung die Krise des Wohlfahrtsstaates?' Berliner Journal für Soziologie 10 (3), pp. 349-379.

Ganßmann, Hans \& Michael Haas (1999), Arbeitsmärkte im Vergleich: Rigidität und Flexibilität auf den Arbeitsmärkten der USA, Japans und der BRD. Marburg: Schüren.

Gomolla, Mechthild \& Frank-Olaf Radtke (2004), Institutionelle Diskriminierung: die Herstellung ethnischer Differenz in der Schule. Opladen: Leske + Budrich.

Goodin, Robert E., Bruce Headey, Ruud Muffels \& Henk-Jan Dirven (1999), The Real Worlds of Welfare Capitalism. Cambridge: Cambridge University Press.

Halfmann, Jost (2005), 'World Society and Migrations: Challenges to Theoretical Concepts of Political Sociology', in Michael Bommes \& Ewa Morawska (eds), International Migration Research: Constructions, Omissions and the Promises of Interdisciplinarity. Aldershot: Ashgate, pp. 129-151.

Hammar, Tomas (1989), 'State, Nation and Dual Citizenship', in Rogers Brubaker (ed.), Immigration and the Politics of Citizenship in Europe and North America. Lanham/ London: Univ. Press of America, pp. 81-95.

Hollifield, James F. (1992), Immigrants, Markets and States: The Political Economy of Postwar Europe. Cambridge, MA: Harvard University Press.

Joppke, Christian (1998), 'Immigration Challenges the Nation State', in idem (ed.), Challenge to the Nation-State: Immigration in Western Europe and the United States. Oxford: Oxford University Press, pp. 5-46.

Kaufmann, Franz-Xaver (2003), Sozialpolitik und Sozialstaat: Soziologische Analysen. Opladen: Leske + Budrich.

Kaufmann, Franz-Xaver (2004), Varianten des Wohlfahrtsstaats. Der deutsche Sozialstaat im internationalen Vergleich. Frankfurt am Main: Suhrkamp.

Klausen, Jytte (2005), The Islamic Challenge. Politics and Religion in Western Europe. Oxford: Oxford University Press.

Kohli, Martin (1986), 'Gesellschaftszeit und Lebenszeit. Der Lebenslauf im Strukturwandel der Moderne', in Johannes Berger (ed.), Die Moderne: Kontinuitäten und Zäsuren (Soziale Welt, Sonderband 4). Göttingen: Schwartz, pp. 183-208.

Koopmans, Ruud (2002), 'Zachte heelmeesters... Een vergelijking van de resultaten van het Nederlandse en Duitse integratiebeleid en wat de WRR daaruit niet concludeert', Migrantenstudies 18 (2), pp. 87-92.

Koopmans, Ruud (2003), 'Good Intentions Sometimes Make Bad Policy: A Comparison of Dutch and German Integration Policies', in René Cuperus, Karl A. Duffek \& Johannes Kandel (eds), The Challenge of Diversity: European Social Democracy Facing Migration, Integration, and Multiculturalism, Innsbruck: StudienVerlag, pp. 163-168. 
Koselleck, Reinhart (1992), 'Volk, Nation. Einleitung', in Otto Brunner, Werner Conze \& Reinhart Koselleck (eds), Geschichtliche Grundbegriffe. Historisches Lexikon zur politisch-sozialen Sprache in Deutschland (vol. 7). Stuttgart: Klett-Cotta, pp. 142-149.

Leibfried, Stephan \& Michael Zürn (2006), Transformationen des Staats? Frankfurt am Main: Suhrkamp.

Luhmann, Niklas (1989), 'Individuum, Individualität, Individualismus', in idem, Gesellschaftsstruktur und Semantik. Studien zur Wissenssoziologie der modernen Gesellschaft 3. Frankfurt am Main: Suhrkamp, pp. 149-258.

Luhmann, Niklas (2000), Organisation und Entscheidung. Opladen: Westdeutscher Verlag.

Maas, Utz (ed.) (2008), Sprache und Sprachen in der Migrationsgesellschaft (IMIS-Schriften, vol. 15). Göttingen: V\&R unipress.

Marshall, Thomas (1950), Citizenship and Social Class - and other Essays. Cambridge: Cambridge University Press.

Michalowski, Ines (2006), 'Qualifizierung oder Selektion? Die Dynamiken der Neuformulierung einer Integrationspolitik', in Anne Walter, Margarete Menz \& Sabina De Carlo (eds), Grenzen der Gesellschaft. Internationale Migration und soziale Strukturbildung (IMIS Schriften, vol. 14). Göttingen: V\&R unipress, pp. 143-162.

Obinger, Herbert, Heinz Rothgang \& Stephan Leibfried (2006), 'The State and its Welfare State: How Do Welfare State Changes Affect the Make-up of the Nation State', Social Policy and Administration 40 (3), pp. 250-266.

Opielka, Michael (2004), Sozialpolitik: Grundlagen und vergleichende Perspektiven. Reinbek bei Hamburg: Rowohlt.

Schmid, Josef (2002), Wohlfahrtsstaaten im Vergleich. Soziale Sicherung in Europa: Organisation, Finanzierung, Leistungen und Probleme. Opladen: Leske + Budrich.

Schönwälder, Karen, Janina Söhn \& Ines Michalowski (2005), Sprach- und Integrationskurse für MigrantInnen: Erkenntnisse über ihre Wirkungen aus den Niederlanden, Schweden und Deutschland (AKI-Forschungsbilanz 3), Berlin: Wissenschaftszentrum Berlin.

Søvik, Margrete (2006), The Social Benefits of Domesticated Religion: Islamic Instruction in German Public Schools, 1979-2001. Dissertation, University of Bergen, Norway.

Soysal, Yasemin (1994), Limits of Citizenship. Migrants and Postnational Membership in Europe. Chicago: University of Chicago Press.

Stichweh, Rudolf (1998), 'Migration, nationale Wohlfahrtsstaaten und die Entstehung der Weltgesellschaft', in Michael Bommes \& Jost Halfmann (eds), Migration in nationalen Wohlfahrtsstaaten. Theoretische und vergleichende Untersuchungen (IMIS-Schriften, vol. 6). Osnabrück: Universitätsverlag Rasch, pp. 49-61.

Swaan, Abram de (1988), In Care of the State. Cambridge: Polity Press.

Therborn, Göran (1995), European Modernity and Beyond: The Trajectory of European Societies, 1945-2000. London: Russel Sage Foundation.

Weinbach, Christine (2005), 'Europäische Konvergenzen: Zur Restitution von Staatsangehörigkeit in Deutschland, Frankreich und Großbritannien', Berliner Journal für Soziologie 15 (2), pp. 199-218. 


\section{Transnationalism or assimilation?}

First published in 2005 by SOWI-ONLINE.DE at www.sowi-online.de/reader/ journal/2005-1/transnationalism_assimilation_bommes.htm

In their analyses of the recent structural effects of international migration, both multiculturalists and transnationalists have criticized the classical frame of analysis in migration research. They argue that the analysis of assimilation processes does not adequately take into account recent processes of cultural pluralisation and the emergence of transnational spaces. This is mainly attributed to assimilation theorists' understanding of society as a nationally closed container, which is seen as one of the problematic assumptions of this approach.

Unsurprisingly, this is seen very differently by researchers interested in assimilation processes (and for reasons of simplification we call them from now on assimilationists) who argue that the paradigm of assimilation research is still the most adequate frame of analysis. They argue that it is still possible and useful to describe even the most recent migration phenomena and the consequences linked with them as ongoing assimilation processes. Hartmut Esser even claims that for migrants there is no serious alternative to assimilation. Access to the most important social resources has become increasingly dependent on access to and success in education, and the different education systems are fundamentally shaped by different national traditions and languages.

Ewa Morawska has attempted to adopt a more moderate position in this debate between assimilationists on the one hand and transnationalists and multiculturalists on the other. She has argued that all processes of migration are linked with processes of assimilation as well as with the emergence of transnational structures. In her view migration research is faced with the task of describing the various migrations and the consequences linked with them as different combinations of transnational and assimilative structures and building typologies of these combinations.

In contrast to these positions, this paper argues that the debate between assimilationists and transnationalists is based on a false opposition. This is mainly due to the use of unclarified theoretical frames of analysis. The 
central aim is to demonstrate that the arguments of transnationalists and assimilationists can be systematically reconstructed as two different hypotheses about the structural consequences of recent international migration. If the two hypotheses are formulated within one common and coherent theoretical framework of analysis, it can be shown that assimilationism and transnationalism do not necessarily refer to different research approaches but rather to two different and competitive hypotheses about the effects of international migration that, as such, are open to empirical tests.

Since the Second World War, Europe has become one of the most important immigration regions in the world. This process has been accompanied by various socio-structural changes that have recently been given much political and scientific attention. Migration research has described these changes with reference to the topic of the multicultural society and to the emergence of so-called transnational structures or spaces. "Multiculturalism", i.e. cultural pluralisation, has been seen as a challenge to the efforts of cultural homogenisation typically undertaken by nation states. And the stress on transnational structures underlines the claim that migration and its effects need to be seen as part of ongoing globalisation processes.

Multiculturalists and transnationalists share the assumption that central structural elements of the nation state are affected by processes of erosion. On the one hand, migration processes imply a growing cultural heterogeneity of the population living on a state territory. This kind of multiculturalism seems to challenge the established programme of the nation state, i.e. the cultural homogenisation of the resident population (Leggewie 1990; CohnBendit, Schmidt 1992; Bade 1996; Brochmann 2003). On the other hand, transnationalism refers to the emergence of social structures that transcend state borders. These structures are seen as the result of enduring migration streams stabilised by transnational networks and organisations. This is accompanied by a change in migrant orientations: migrants start to orientate themselves towards transnational opportunity structures; the nation state and its classical aim of social integration loses relevance as a frame of action. But this paper does not focus on the structural consequences of cultural pluralisation, multiculturalism and transnationalism but rather on the scientific debate between what is termed here transnationalists and assimilationists.

1 Transnationalists ${ }^{1}$ have argued that migration research should replace its more or less outdated research design based on a methodological nationalism. It is argued that transnational structures render visible the constraints of the concept of a national society which is attacked as a "container concept" of society. In the eyes of transnationalists, assimilation research is therefore characterised by a limited frame of analysis still conceptualis- 
ing migration and its social consequences as a problem of migrants' assimilation to the host society, its dominant groups and the cultures linked with them. But transnational migrants, it is claimed, do not any more orient their modes of life towards this type of container society but rather to the structural contexts provided by emergent transnational spaces. These emergent structures cannot be grasped adequately by a nation state concept of society.

At the centre of the argument is the claim that more and more migrants are becoming so-called transmigrants. This type of migration cannot adequately be taken into account by the classical pattern of description conceptualising migration as a one-way move from an emigration country to an immigration country. The life courses of migrants are more and more marked by their participation in transnational social relations. They are leading not just one- or bi-directional, but multi-directional lives. The result is the emergence of pluri-local modes of life of these migrants. In the eyes of transnationalists migration is becoming a continuous process in time and space. Transmigration and the new pluri-local social spaces are not just seen as the extension of the migrants' origin communities but as independent social structures. According to transnationalists, as a result we can observe the emergence of combined "bounded-nomadic" modes of life. Under the conditions of globalisation and the diffusion of new technologies of communication and transport these new types of transmigrants are gaining more and more relevance. "This perspective on transnationalism and transmigration and the re-conceptualisation of society, community and nation state linked with it underlines the new importance of migration for the diagnosis of recent social transformations by the social sciences" (Pries 2001b, 53).

Transnationalists argue that the developments identified as transnational social structures or spaces can best be grasped by research approaches which have become prominent as network analyses, theories of cumulative causation, migration systems theories and globalisation theories.

2 These rather straightforward positions have been confronted with a whole array of objections by American and European assimilationists. These assimilationists claim that a theoretically reflected concept of assimilation still provides the best frame for the analyses of even the most recent immigration processes in Europe or the US. The classical concept of assimilation as developed by Milton Gordon certainly needs to be amended and re-conceptualised but this does not affect the strength of the general approach. Notably, Alba and Nee (1997) and Brubaker (2001) have discussed the recent empirical results of the American immigration research. They demonstrate that these results can be interpreted without difficulty as providing evidence for ongoing assimilation processes even among the most recent migrants that immigrated only after the 1960s. They argue that the majority of these migrants is looking for labour on open labour markets 
and that these markets seem to be much more open than is often assumed. These very same migrants seem to be able to gain an amount of income in rather short periods of time that comes close to the level of income of the resident population. Assimilationists therefore argue against an overestimation of ethnic economies and their transnational character. Similar arguments are put forward concerning the areas of housing, education, and language. Some of the empirical results of research done in these fields are ambiguous but there are strong indicators for progressive assimilation processes which seem to be similar to those that were described for earlier immigration waves in the US. The scholars reach the conclusion: "Assimilation still matters."

The most prominent German assimilationist Hartmut Esser (2001) has put on top of this the claim that assimilation not only still matters but that there is in fact no alternative to it. He argues that successful participation in education is becoming more and more decisive for individual competitiveness on labour markets and for any efforts to gain access to the important resources for a decent living. Since the education systems are moulded by national cultures there is no alternative for migrants to the necessity to learn the national language of the country they have entered.

3 Ewa Morawska (2002) has tried to take a more moderate position in this debate between transnationalists and assimilationists. She proposes analysing the social consequences linked with migration as the combined result of transnational and assimilation processes. According to Morawska the relation between transnational and assimilative structures should be seen as dynamic and changeable in both directions. Jointly with historians like Bade (2000), Gerber (2000), Lucassen (2004) and others, she argues that much of what is described by transnationalists as only recent developments is not entirely new and could already be observed for earlier migration movements. Morawska proposes to do more comparative empirical research and to build typologies that grasp the various combinations of transnational and assimilative structures to be found among different migrant groups. The aim should be to develop theories that explain the emergence and reproduction of these different types.

4 Morawska's proposal is instructive. However in this paper we take a different perspective. We agree with multiculturalists and transnationalists to a certain extent. Indeed, processes of cultural pluralisation are one consequence of international migration. We also assume that transnationalisation processes can be observed in an empirical sense. Many migrants' modes of life may not be primarily orientated towards the frame of the nation state. Migrants are more or less continuously included in bordertranscending social structures concerning family, economic, legal, political or educational relations. But these empirical observations do not imply what transnationalists like to suggest (on a rather unclear theoretical basis; see Bommes 2003a), namely the need for completely new concepts and 
theories in migration research. It seems that there is rather a need for a theoretical framework that allows us to systematise the arguments put forward by the opponents and to clarify the systematic relation between them.

Referring to the empirical observations just mentioned it has been argued against classical migration research that its frame of explanation is too narrow and still too much guided by the traditional (and seemingly somewhat outdated) problems of integration and cultural assimilation. The frames of reference for assimilation are reference groups and the national society. Assimilationists have refuted this critique by referring to empirical results of research which seem to support their position. Morawska's effort to mediate between the two positions perpetuates the conceptual opposition between assimilation to the social structures of the host society on the one hand and the emergence of transnational structures on the other. Another option would be to deconstruct the seeming conceptual oppositions and to recombine them theoretically in a different way.

In order to do this we replace a concept that understands society as a big collectivity by a concept of modern world society, i.e. a society that is functionally differentiated into different realms (such as the economy, politics, law, science, education, health, etc.) and modern organisations (Luhmann 1997). The chances of individuals participating and getting access to social resources are mediated by these differentiated social systems. We assume that cultural pluralisation processes as well as national closure or transnational opening are contextually dependent on the structural development of social systems. And we are interested in the implications of this classical mainstream sociological perspective - present in the work of Marx, Weber, Durkheim but also Parsons, Habermas and Luhmann, understanding modern society as differentiated society - for an understanding of the debate between transnationalists and assimilationists.

\section{II}

Multiculturalists have always exaggerated. And transnationalists have followed up this exaggeration through different means. The exaggerations are the result of theory politics and not truly convincing. In contrast to both positions, we want to stress however that any migration implies assimilation.

This becomes visible if we look at the frame of analysis that is operationally used in empirical research. This should be distinguished from the self-understanding employed by researchers. One weakness of classical migration research and its mode of posing the problem of integration and assimilation was indeed the use made of the concept of groups and the concept of the national society. Social structures are basically seen as collective structures. Any social event is therefore described with reference to "groups" or to "society". Correspondingly the distinction between origin 
and host society is still prominent. Concerning the host society, the nation state and its integration programme still form the implicit or explicit background. These conceptual weaknesses are criticised by transnationalists who point to globalisation and the resulting transnational social structures.

But a closer look at what assimilation researchers actually do proves that "groups" or "the society" are not at all the frame of reference for empirical research in operational terms. This would make no sense anyhow, as will be pointed out in two steps. If assimilation implies a process of becoming similar, we need to clarify the point of reference in relation to which that process of becoming similar takes place. Second, we will have to elaborate on the various dimensions of that process.

Individuals migrate for different reasons. They may be looking for labour, education, health treatment, to join their family or to flee political repression or ecological decline. For all of these migrants, it does not seem plausible to conceptualise the problem of assimilation with reference to groups or society. In order to work or study, to apply for asylum or to seek health treatment, individuals usually cannot address either "groups" or "the society". Access to labour, the treatment of patients, the education of pupils or students, the taking of exams and the decision on asylum applications are not provided by groups. The same is true for society which simply cannot be addressed as such and which can therefore not be the reference point for any effort to become similar (or dissimilar). Processes of assimilation emerge inside the organisations of the important functional realms of modern society, i.e. in enterprises, hospitals, schools, universities, and administrations. They emerge when individuals start to work or try to get access to goods, education, rights, social welfare, and so on. Every individual that intends to work or to gain access to these provisions must fulfil the expectations that define the social preconditions for the success of these efforts. Every individual must therefore have some knowledge of what it means to work or how to behave as a patient, a client, a pupil, a student, or an applicant.

If we start from these rather simple considerations and apply them to the behaviour of different migrant categories - labour migrants, refugees, family migrants, and so on - we see immediately that all migrants do assimilate when they take roles inside organisations and fulfil the bundles of social expectations linked with these roles, even if they do this to a different extent. We would not be able to understand how migrants succeed - and they obviously do - in acting inside a variety of organisations if they did not assimilate to the expectations linked with these roles. They not only do conform to these expectations, but they also develop corresponding expectations about the expectations of these organisations.

These rather obvious necessities of assimilation cannot be avoided, not even by social networks. Social networks may mediate and modify the indispensable necessities of assimilation. But most migrants, like most 
individuals, are dependent on opportunities to get access to and to participate in organisations.

Seen in this way the fact of assimilation seems to be almost trivial. It belongs to the basic conditions of the mode of individual life in modern society. Individuals no longer gain social belonging and social opportunities via birth or lineage. Each individual is responsible himself for finding opportunities of access to and inclusion into the social systems of society (Luhmann 1989). This includes the necessity to assimilate in a context, i.e. system-specific manner, according to the differentiated systems of modern society and their expectations. Any individual can be included in the economy, politics, law, education, science, health or the mass media and the related organisations if they fulfil the specific preconditions for a competent participation in the respective system. Otherwise, they will be excluded. In order to participate in the economy, education or the health system, individuals must have money or should be educatable or ill. They must be responsible, competent and disciplined in order to take over membership roles in organisations. In other words: individuals in modern society are expected to orient their modes of life to the conditions of participation in the differentiated social systems and to develop corresponding competence and willingness to participate. This is to say that all individuals in modern society must assimilate.

Migrants declare their preparation for assimilation by the simple fact of migration itself, since migration in modern society means the effort to find access to social systems in a different geographical place by means of migration (Bommes 1999).

To stress the main point again: assimilation refers to a general condition of existence for all individuals in modern society, i.e. the permanent expectation that they will control their behaviour and action according to the structural conditions of the differentiated social systems. Seen in this way the problem of migrant assimilation refers to no more (and no less) than to the conditions under which they succeed or fail to fulfil the conditions of participation in social systems.

\section{III}

In order to describe the conditions of participation in social systems more precisely it is useful to distinguish different dimensions of assimilation. Modifying Gordon's model (Gordon 1964), Hartmut Esser (1980) has distinguished four dimensions: cognitive, structural, social and identificational assimilation. If we understand assimilation as a process related to the expectations valid in social systems - and not groups or societies - it is easy to identify the simple systematic of these distinctions. 
Cognitive assimilation refers to the assimilation of structures on the side of the individual in order to fulfil conditions of inclusion in social systems. Individuals learn languages, skills, behavioural and situational patterns, normative knowledge, orientations towards mobility, and so on.

Structural assimilation refers to a more or less successful process of acquiring membership roles in organisations, earning an income, and securing occupational and legal status as well as formal education. This form of assimilation therefore refers to the structure of migrants' empirical participation in social systems (plural!) and to social resources like income, education, rights, health, reputation, etc. that are mediated by participation and which determine the social status of migrants. It is obvious that the assimilation branch of migration research is centrally situated in the long tradition of the sociology of social inequality. The main assumption here is that in modern society, inequality is structured as social inequality. Assimilation research assumes that these structures also regulate migrants' access to those social resources that are most relevant for the range of life options that may be realised.

Social assimilation refers to migrants' social relations such as friendships, marriage, clubs and other associations or social networks. Migration research focuses here on interethnic relations and assumes interdependencies between structural and social assimilation.

Identificational assimilation finally refers to the claims of belonging and identity made by migrants themselves and to the forms of identity made use of. Research here is usually interested in migrants' intentions to return or be naturalised, their ethnic belonging, language use and political orientations.

Based on these distinctions, assimilation research stresses two important points: immigrants' assimilation efforts are usually confronted with social barriers. These barriers need to be analysed with reference to the specific systems in which they occur. They can be found in firms concerning access to workplaces, in schools concerning migrant children's success, in states concerning access to citizenship and rights, in families concerning access to education, friendships or interethnic relations.

In the course of its history, migration research has not always had the same understanding of assimilation. But on the whole it was generally assumed that there is a strong relation of correspondence between the different dimensions of assimilation that have been sketched above. And this is quite plausible because an individual with more cognitive preconditions is more likely to be competent in fulfiling the expectations of membership roles. An individual with a secure and more or less well paid occupational position will find both easier access to health, education, rights and politics, and more social recognition and social relations. In addition, individuals who live regularly in those secure social contexts will develop corresponding cognitive structures, and so on. 
The same holds true the other way round. It is unlikely that individuals living in a narrow ethnic milieu will acquire the cognitive structures necessary to fulfil the expectations of schools, to be occupationally successful or to gain access to attractive and well-paid positions in organisations. The same milieu is liable to reduce access to social networks, friendships and clubs outside of it. This in turn is why members of this milieu will hardly have feelings of belonging beyond its borders. Both successful assimilation to the expectations of social systems, and its failure, seem to have a highly self-perpetuating character.

We may call these assumptions the strict coupling hypothesis of the assimilationists. They assume a narrow or strict coupling between the different forms of assimilation (and may disagree amongst each other which form of assimilation is of primary importance).

\section{IV}

We will not engage in an argument with this hypothesis but rather shall try to show how the claims of the multiculturalists and the transnationalists relate to the strict coupling hypothesis of assimilation research. Our main points will be:

A. Cultural plurality and assimilation do not contradict each other.

B. The arguments of transnationalism can be reconstructed as an effort to question the hypothesis of a strict coupling between the different forms of assimilation with reference to the empirical effects of globalisation. This central point and drift of the transnationalist argument can be rendered visible if we use the general frame of a theory of modern, i.e. differentiated society.

$A$ Cultural plurality and assimilation do not contradict each other. Multiculturalism underlines processes of cultural pluralisation and describes these as major social challenges. But modern organisations and functional realms like the economy, politics, law, education or health have already to a large extent deregulated cultural life forms, and this does not seem to be causing major social turbulences (Bommes 2003b). At the same time individuals must be aware of those expectations that are valid in the realms of education, work, law, health, and so on. To give an example: schools expect a population of pupils that is multilingual and culturally as well as religiously heterogeneous. Schools do not intend to repair this heterogeneity, but they expect pupils to acquire literacy, to learn the generalised language of intercourse and to develop other formal qualifications. The aim is not to create a homogeneous school population as a community (i.e. "assimilation" as the political program of the nation state of the 19th and early 20th centuries; see Maas 1984, Therborn 1995), but to educate 
individuals in a way that they become competent to participate in social systems. Hospitals are more and more prepared to treat patients of different origin, language and culture. Firms take into account the religious orientations of their staff. Politics and nation states in Western Europe no longer see cultural homogenisation as a precondition for longterm residence, settlement and naturalisation (Joppke 2001). And the law protects individuals against discrimination for religious or cultural reasons.

Against this background we may speak of a factual multiculturalism in Europe which has been confronted with amazingly little resistance by the European nation states - amazing at least if one recalls the anxieties articulated at the end of the 1980s and the beginning of the 1990s. At that time multiculturalism and cultural plurality as an effect of migration were seen as a challenge for the nation state and its seemingly indispensable program of cultural homogenisation of the resident population. We may think here of the prominence of Brubaker's (1992) comparison of France and Germany.

To sum up: multiculturalism and assimilation do not contradict each other. Modern organisations in different realms can cope quite well with pluralised cultural orientations - which does not mean that individuals can cope with it just as easily. They may fail in their efforts to find access and inclusion if they fail to assimilate. The main point of reference for assimilation is differentiated social systems: organisations and functional realms like the modern economy, law, politics, science, education or health but not groups of (majority) societies. Assimilation to social systems refers to a social condition that applies in a culture-transcending manner - it is in any case not culturally specific.

$B$ On closer inspection transnationalism does not contradict the assimilation thesis either. The main thesis of transnationlism is that globalisation leads to a loose coupling of the forms of assimilation, i.e. cognitive, structural, social and identificational assimilation. The substance of the debate between transnationalists and assimilationists is two different and competing hypotheses about the consequences of international migration which can be tested empirically. The debate therefore should not primarily be taken as a debate between two theoretically completely different approaches.

The claim that transnational relations or spaces are currently expanding empirically refers to something different from what is asserted by multiculturalists. According to these assertions, the social systems to which individuals try to find access are not confined to the borders of nation states. This implies that individuals lead their lives in ways that transcend state borders. This may be the case for various realms like the family, education, health, the economy or politics. To give an example: migrants work in the host context in order to invest money, to care for the family and to engage in local or national political projects in the context of origin. Successful 
migrants invest money in the context of origin in order to develop a new industry as in the case of Indian IT-specialists. These transnational modes of life can be found in different social contexts and in various combinations depending on migrants' different access and control over resources. This has been shown by the research of a number of scholars (e.g. Hunger 2000; Levitt 1998, 2001; Müller-Mahn 2000; Singhanetra-Renard 1992).

On closer inspection it again becomes evident that the arguments of transnationalists do not contradict the assumption that there is no alternative to assimilation in modern society. This contradiction holds only as long as the frames of analysis are not clarified.

To state the main hypothesis again: even transnational migrants do have to assimilate - to the expectations of those social systems in which they want to participate. This means for them that, for instance, they may have to find a balance between the expectations of their family in the context of origin and the conditions of achievement at the workplace or in organisations of education in the immigration context.

It is important to keep this in mind since it allows us to realise what precisely is controversial between assimilationists and transnationalists. The critique concerning conventional migration research by transnationlists argues that this type of research is still too much confined to "methodological nationalism" (Wimmer \& Glick-Schiller 2001). This is seen as the reason why assimilation is conceptualised based on a container concept of society and related to a concept of integration that still uses the nation state as the central frame of reference.

This argument is right and wrong at the same time. It is right since assimilationists do indeed conceptualise society as a big national collective society. It is wrong in that the actual subject of assimilationist empirical research is something very different, i.e. the connection between the different forms of assimilation (cognitive, structural, social, identificational), as discussed above. Combined with this focus is a strong socio-structural hypothesis: the assumption of a strict coupling between the different forms of assimilation. Assimilationists assume a strong link between individual cognitive structures as a precondition for assimilation (indicators are education and language in particular, i.e. the existence of structures that allow the building of further structures), structural assimilation (measured by achieved social status), social assimilation (access to non-ethnic networks) and identificational assimilation (collective, especially ethnic and national identity). The main thesis implies principally two points: 1) It can be observed that migrants enter those coupled assimilation processes (they enter education, strive for social status, change their social networks and forms of self-identification); this shows that the different forms of assimilation remain relevant for migrants. 2) It can be demonstrated that assimilation remains central for their life chances. Only then can they reach the level of life chances of the non-migrant population. Failure to assimilate results in 
e.g. the emergence of segregated ethnic milieus. There may be diver-sification, but ongoing assimilation processes are more likely and in the end unavoidable.

This implies a further thesis which is empirically interesting but hidden by the ongoing use of a national concept of society and the corresponding "methodological nationalism". The thesis can be rendered visible if we reconstruct assimilation in the way proposed above. The implied thesis is that the nation state is still a decisive frame for the structure of the relations of distribution and inequality even in a globalised world society. The connections between the different forms of assimilation remain regulated and strictly coupled because of the continuous importance of the nation state. Even under the conditions of globalisation these relations are still not loosely coupled and contingent. To put it differently: it remains unlikely that especially the structural, social and identificational forms of assimilation vary arbitrarily. Hartmut Esser has emphasised this point by arguing that education systems are shaped by national cultures and that national languages preserve their continuous relevance.

For reasons of clarity we again underline that assimilation research is thus based on the general paradigm of inequality research, implying the following core assumptions:

- The relations of distribution in modern society are structured relations, i.e. they produce structured social inequality linked with the emergence of identifiable social groups which we call classes.

- The relations of distribution are still mediated by nation states. Beneath the transcending relations of international inequality embodied in the North-South and East-West imbalance, the structures of social inequality are essentially nationally segmented and structured. ${ }^{2}$

- Structured inequality means that the distribution of social resources such as money, occupational position, education, health, rights and political influence is not likely to vary arbitrarily. Social advantages tend to cumulate where advantages can already be found, and this form of social inequality tends to be reproductive and self-perpetuating. Individuals with good chances of participation in social systems and access to social resources tend to build networks securing and safeguarding these opportunities and corresponding collective identities. At the same time they care for conditions that allow the maintenance and reproduction of individual competences for themselves and their children which, in turn, constitutes a precondition for access to social systems and social resources.

- To a large extent assimilation research means the application of the above assumptions to the field of migration research. The measurement of assimilation in these different dimensions is used as an indicator for migrants' success or failure to penetrate existing relations of distribution. 
Interethnic relations are evidence of penetration of the relevant reproduction networks of social inequality by migrants.

Seen against this background it is easy to identify the antithesis of transnationalism (if we leave aside some conceptual problems and metaphors such "transnational spaces"; see Bommes 2003a). The central thesis of transnationalism is that we witness a decoupling of the different forms of assimilation. This in turn implies the more general thesis that transnational developments are part of a general process of destructuration of social inequality - a process that has been registered independent of migration research and the consequences of which are the subject of an ongoing sociological debate. The thesis of decoupling is based on the following empirical observations:

- The participation of more and more migrants in different social systems is distributed over several locations ("plurilocal") and regularly transcends nation state borders (it is "transnational"). It is open to debate whether these processes are enduring and stable, but this would imply that the interconnections between the chances of participation in the different social systems like the family, economy, law, education, politics and health could change. In this view they tend to be less and less controlled or mediated by established national welfare regimes, and these regimes may themselves be eroded by these changes.

- Participation in social systems is more and more mediated by transnational migrant networks. These networks organise access and inclusion. Connected with this is the assumption that social assimilation in the sense explained before loses relevance. Assimilationists assume that the enduring existence of ethnic milieus is mainly an indicator of the reproduction of structured inequality restricting migrants' social options. Transnationalists emphasise instead the potential of those networks for the mediation of social options.

- The diversification of collective identities is seen as a symptom for migrants' reorientation to the nationally decoupled and transnationally mediated forms of identificational assimilation.

- The emergence of transnational competences finally evidences a change in the conditions of cognitive assimilation. These assimilation processes take place now in relation to the transnationally structured conditions of participation in social systems.

To sum up: compared to the position of assimilationists it becomes evident that transnationalism puts forward a decoupling hypothesis. The forms of assimilation are undergoing a process of decoupling under the conditions of globalisation. Transnationalism implies that new oportunities of variation between these forms emerge. In this sense the forms of assimilation are loosely coupled in a globalised world and the nation state loses its 
relevance for social integration, i.e. the restriction of variation between these forms of assimilation.

\section{V}

What are the consequences of this mode of reconstructing the positions of assimilationists and transnationalists? It is easy to see now that transnationalism and assimilationism do not necessarily refer to different theoretical approaches. What is at issue between transnationalists and assimilationists is the strict or loose coupling of the different forms of assimilation. This does not prove in itself the need for different approaches - rather the contrary. Reconstructed in the general frame of a theory of modern society the dispute between the positions gains transparency. The substitution of theoretical concepts for metaphors like transnational spaces rather hides the substance of the dispute. ${ }^{3}$ But the blind spots that become visible by comparing the two positions with reference to the theoretical frame used in this paper are instructive.

1 The assimilationists show that transnationalists neglect the enduring mediation of chances of social participation of migrants by nationally established relations of social inequality and welfare states. The assumption of the diminishing relevance of the nation state seems to be a nearly conceptual starting point. For this reason they also fail to notice that the emergence of transnational structures may even be a consequence of the specific modes in which national welfare states treat migrants and include or exclude them politically. In this sense nation states are part of and to some extent even the precondition for the emergence of transnational structures (Koopman \& Statham 2002). Trans-nationalism itself is still influenced by the classical claim of the nation state to be the head and centre of society. For that reason, transnationalism has no theoretical concept of society anymore and tends to understand globalisation without nation states or with only a very limited version of that institution. For the same reason, transnationalists seem to have serious difficulties in conceptualising the challenge of the empirical phenomena they refer to in theoretically adequate concepts, i.e.:

A. that the consequence of the emergence of transnational structures and modes of living may be the destructuration of the institutionalised forms of social inequality so far mediated by national welfare states and

B. that this precisely means a serious challenge for assimilation research. But this may be a challenge not because assimilation does not matter anymore, but because relations of assimilation may become loosely coupled as an effect of the re- or destructuration of the relations of social inequality formerly strongly mediated by the 
institutions of the national welfare state. If this is the case, it cannot be conceptually derived but needs to be demonstrated by empirical research trying to answer questions like the following: What precisely are the transnational forms and constellations of migrants' participation in various social systems? In which contexts do these transnational structures emerge? What are the mechanisms of stabilisation for these structures and under which conditions do they dissolve? What kind of effects do these transnational structures have on the established relations of distribution and social inequality?

2 The transnationalists show that assimilationist approaches employ the nation state as a tacitly presupposed frame of reference not least because of the underlying concept of national society. The mediation of the relations of social inequality and assimilation by national welfare states is a premise of analysis in this approach rather than an emprical fact that needs further analysis concerning its social and historical preconditions. As a consequence the assimilationist approach should become more open for a discussion about the role of the nation state and the extent to which the coupling of assimilation forms may be socially contingent. This would open the field for empirical research of potentially alternative developments. The main debates of migration research would then be less concerned with the (false) opposition of transnationalism versus assimilation, and more with the description and explanation of social structures in a world society which may or may not be combined with changing relations of assimilation.

\section{Notes}

I Among the numerous publications see Bauböck 1994; Glick, Schiller, BlancSzanton 1995; Faist 2000; Hannerz 1996; Levitt 2001; Ong 1997; Portes 1996; Pries I997, 200Ia; Vertovec 200I; a general reader is provided by Vertovec, Cohen I999.

2 This can also be seen by the fact that most research on social inequality focusses on the description of nationally structured inequality. In a similar way Stichweh (I998) underlines the role of the national welfare state as an "institutionalised threshold of inequality".

3 The continuous repetition of these metaphors and the proclamation that this is a new theoretical approach opening up new perspectives to the various disciplines of migration research (see recently Gogolin \& Pries 2004) continue to hide the substance of this dispute. 


\section{References}

Alba, Richard \& Victor Nee (1997), 'Rethinking Assimilation Theory for a New Era of Immigration', International Migration Review vol. 31, pp. 826-874.

Bade, Klaus J. (ed.) (1996), Die multikulturelle Herausforderung. Menschen über GrenzenGrenzen über Menschen. Munich: C. H. Beck.

Bade, Klaus J. (2000), Europa in Bewegung. Migration vom späten 18. Jahrhundert bis zur Gegenwart. Munich: C. H. Beck.

Bauböck, Rainer (1994), Transnational Citizenship: Membership and Rights in International Migration. Aldershot: Edward Elgar.

Bommes, Michael (1999), Migration und nationaler Wohlfahrtsstaat. Ein differenzierungstheoretischer Entwurf. Opladen/Wiesbaden: Westdeutscher Verlag.

Bommes, Michael (2003a), 'Der Mythos des transnationalen Raumes. Oder: Worin besteht die Herausforderung des Transnationalismus für die Migrationsforschung?' in Dietrich Thränhardt \& Uwe Hunger (eds), Migration im Spannungsfeld von Globalisierung und Nationalstaat. Leviathan Sonderheft No. 22. Wiesbaden, 90-116.

Bommes, Michael (2003b), 'The Shrinking Inclusive Capacity of the National Welfare State: International Migration and the Deregulation of Identity Formation', in Grete Brochmann (ed.), The Multicultural Challenge (Comparative Social Research 22). Oslo: Elsevier, pp. 43-67.

Brochmann, Grete (ed.) (2003), 'The Multicultural Challenge', Comparative Social Science Vol. 22. Oslo: Elsevier.

Brubaker, Rogers (1992), Citizenship and Nationhood in France and Germany. Cambridge, MA: Harvard University Press.

Brubaker, Rogers (2001), 'The Return of Assimilation? Changing Perspectives on Immigration and its Sequels in France, Germany, and the United States', in Ethnic and Racial Studies Vol. 24 (4), pp. 531-548.

Cohn-Bendit, Daniel \& Thomas Schmidt (1992), Heimat Babylon. Das Wagnis der multikulturellen Demokratie. Hamburg: Hoffmann und Campe.

Esser, Hartmut (1980), Aspekte der Wanderungssoziologie. Darmstadt and Neuwied: Luchterhand.

Esser, Hartmut (2001), 'Kulturelle Pluralisierung und strukturelle Assimilation. Das Problem der ethnischen Schichtung', Schweizerische Zeitschrift für Politikwissenschaft, Vol. 7 (2), pp. 97-108.

Faist, Thomas (2000), The Volume and Dynamics of International Migration and Transnational Social Spaces. Oxford: Oxford University Press.

Gerber, David A. (2000), 'Theories and Lives: Transnationalism and the Conceptualization of International Migrations to the United States', in Michael Bommes (ed.), Transnationalismus und Kulturvergleich (IMIS-Beiträge 15). Osnabrück, pp. 31-54.

Glick Schiller, Nina, Linda Basch \& Christina Blanc-Szanton (1995), 'From Immigrant to Transmigrant: Theorizing Transnational Migration', Anthropological Quarterly, Vol. 68, pp. 48-63.

Gordon, Milton M. (1964), Assimilation in American Life: The Role of Race, Religion, and National Origins. New York: Oxford University Press.

Hannerz, Ulf (1996), Transnational Connections: Culture, People, Places. New York: Routledge.

Hunger, Uwe (2000), 'Vom >Brain-Drain` zum >Brain-Gain`. Migration, Netzwerkbildung und sozio-ökonomische Entwicklung: das Beispiel der indischen `Software-Migranten`' (IMIS-Beiträge 16), University of Osnabrück, pp. 7-21.

Joppke, Christian (2001), 'Multicultural Citizenship, A Critique', in Archives Européennes de Sociologie Vol. 42, pp. 431-447. 
Koopmans, Ruud \& Paul Statham (2002), 'How national citizenship shapes transnationalism: A comparative analysis of migrant and minority claims-making in Germany, Great Britain and the Netherlands', in Ewa Morawska \& Christian Joppke (eds), Toward Assimilation and Citizenship in Liberal Nation-States. London: Palgrave, pp. 195-238.

Kritz, Mary M., Lin Lean Lim \& Hania Zlotnik (eds) (1992), International Migration Systems: A Global Approach. Oxford: Oxford University Press.

Leggewie, Claus (1990), MultiKulti: Spielregeln für die Vielvölkerrepublik. Berlin: Rotbuch.

Levitt, Peggy (1998), 'Local Level Global Religion: The Case of U.S.-Dominican Migration', Journal for the Scientific Study of Religion Vol. 37, pp. 74-89.

Levitt, Peggy (2001), The Transnational Villagers. Berkeley: University of California Press.

Lucassen, Leo (2004), 'Assimilation in Westeuropa seit der Mitte des 19. Jahrhunderts. Historische und historiographische Erfahrungen', in Klaus J. Bade, Michael Bommes \& Rainer Münz (eds), Migrationsreport. Fakten - Analysen - Perspektiven. Frankfurt am Main/New York: Campus, pp. 43-66.

Luhmann, Niklas (1989), 'Individuum, Individualität, Individualismus', in idem, Gesellschaftsstruktur und Semantik. Studien zur Wissenssoziologie der modernen Gesellschaft 3. Frankfurt am Main: Suhrkamp, pp. 149-258.

Luhmann, N. (1997), Die Gesellschaft der Gesellschaft, 2 vols. Frankfurt am Main: Suhrkamp.

Maas, Utz (1984), Als der Geist der Gemeinschaft eine Sprache fand. Sprache im Nationalsozialismus. Opladen: Westdeutscher Verlag.

Morawska, Ewa (2002), 'Immigrant Transnationalism and Assimilation: A Variety of Combinations and the Analytic Strategy it Suggests', in Ewa Morawska \& Christian Joppke (eds), Toward Assimilation and Citizenship in Liberal Nation-States. London: Palgrave Macmillan, pp. 133-176.

Morawska, Ewa \& Christian Joppke (eds) (2002), Toward Assimilation and Citizenship in Liberal Nation-States. London: Palgrave Macmillan.

Müller-Mahn, Detlef (2000), 'Ein ägyptisches Dorf in Paris. Eine empirische Studie zur SüdNord-Migration am Beispiel ägyptischer \Sans-papiers` in Frankreich', in Michael Bommes (ed.), Transnationalismus und Kulturvergleich (IMIS-Beiträge 15). Osnabrück, pp. 79-110.

Ong, Aihwa (ed.) (1997), Ungrounded Empires: The Cultural Politics of Modern Chinese Transnationalism. New York: Routledge.

Portes, Alejandro (1996), 'Transnational Communities: Their Emergence and Significance in the Contemporary World-System', in Roberto Patricio Korzniewidcz \& William C. Smith (eds), Latin America in the World Economy. Westport, CT: Greenwood.

Pries, Ludger (ed.) (1997), 'Transnationale Migration', Soziale Welt, Sonderband 12. BadenBaden: Nomos.

Pries, Ludger (2001a), 'The Disruption of Social and Geographic Space. Mexican-US Migration and the Emergence of Transnational Social Spaces', International Sociology Vol. 16, pp. 55-74.

Pries, Ludger (2001b), Internationale Migration. Einführung in Klassische Theorien und neue Ansätze. Bielefeld.

Singhanetra-Renard, Anch'alee (1992), 'The Mobilization of Labour Migrants in Thailand: Personal Links and Facilitating Networks', in Mary M. Kritz, Lin Lean Lim \& Hania Zlotnik (eds), International Migration Systems: A Global Approach. Oxford: Oxford University Press, pp. 190-204.

Stichweh, Rudolf (1998), 'Migration, nationale Wohlfahrtsstaaten und die Entstehung der Weltgesellschaft', in Michael Bommes \& Jost Halfmann (eds), Migration in nationalen Wohlfahrtsstaaten. Theoretische und vergleichende Untersuchungen (IMIS-Schriften, vol. ๑). Osnabrück: Universitätsverlag Rasch, pp. 49-61. 
Therborn, Göran (1995), European Modernity and Beyond: The Trajectory of European Societies, 1945-2000. London: Russel Sage Foundation.

Vertovec, Steven (2001), 'Transnational Social Formations: Towards Conceptual CrossFertilization', Paper presented at the workshop 'Transnational Migration: Comparative Perspectives'. Princeton University, 30 June to 1 July.

Vertovec, Steven \& Robin Cohen (eds) (1999), Migration, Diasporas and Transnationalism. Cheltenham: Edward Elgar.

Wimmer, Andreas \& Nina Glick-Schiller (2001), 'Methodological Nationalism and Beyond: Nation-State Building, Migration and the Social Sciences', Paper presented at the workshop 'Transnational Migration: Comparative Perspectives'. Princeton University, 30 June to 1 July. 


\title{
6 'Integration takes place locally'
}

\author{
On the restructuring of local integration policy
}

First published in 2008 by Campus Verlag for the Council on Migration (RfM) as the chapter "IIntegration findet vor Ort statt": Über die Neugestaltung kommunaler Integrationspolitik' (pages 159-194) in Migrationsreport 2008: Fakten - Analysen - Perspektiven, edited by Michael Bommes and Marianne Krüger-Potratz

Reprinted in 2011 in 'Migration und Migrationsforschung in der modernen Gesellschaft' in IMIS-Beiträge 38 (pages 187-220)

Translation into English for this book by Anja Löbert

'Integration takes place locally': this motto accompanies a multitude of events which for some time now have been organised in cities, municipalities and rural districts in Germany for dealing publicly with the subject of migration and integration. A great many of these events are associated with public commitments to integration. Perhaps in the past the subject has been given too little attention and not been treated systematically enough. Or perhaps this has in fact always been done, but in the future it needs to be done even more intensively and systematically. There is, accordingly, a need for directing all responsible authorities in the local community towards this end, while gaining greater support among local citizens for this subject. 'In the future it will also be the municipalities that will have to provide the bulk of integration support services. ${ }^{, 1}$ In this connection, local integration plans or concepts are being newly drafted or rewritten, options for the longer-term monitoring of integration are being examined and appropriate initiatives are being subsumed under the motto of intercultural openness, of integration management and diversity management.

The present text $\mathrm{t}^{2}$ examines the question of what has set in motion this realignment of municipalities and led them to make integration policy a central concern of their local policy. In the first section we discuss various suggestions for explaining this. In a second step we recommend embedding this realignment in the changes being made in the integration policy of the German federal welfare state, changes that result from the political 
realisation that migrants have become the normal clientele of political administration and that migration has become a normal structural feature of the population. In the third step we argue - against this backdrop - that municipalities have been pushed to this new integration policy in recent years through political mobilisation from within and without, and we consider their various efforts toward realignment to be attempts to lend their integration policy a legitimate, publicly recognised institutional form by aligning it to relevant models. In the conclusion we address the issue of the consequences of the analysis for the evaluation of future local integration policy.

\section{What Explains 'the Time for Integration' in Municipalities? Open Questions}

Many welfare associations, churches, private institutions (in modern German: NGOs) and other entities have for a long time been pointing out that immigration and the settlement of migrants (which has been occurring for decades) need public recognition by politics and, in association with this, an appropriate migration and integration policy geared towards it. In recent years, these entities have had to register the fact that their unrelenting efforts and their insistence on the importance of the topic are now being crowned with a success that has almost taken them by surprise. They are certainly entitled to lament the fact that this has either happened too late and should have occurred long ago, or that quite a few things have in their view been tackled incorrectly, because their expertise was not drawn on in time or not drawn on at all.

Migration researchers, too, find themselves confronted with the virtually astounding success of their policy counselling. In the early 1990s they had presented a "Manifesto of the $60^{, 3}$ in which they warned about the need for no longer ignoring the issues of migration and integration and for acknowledging its great importance in bringing about a politics with a future. Soon afterward, this was followed by the founding of the Council for Migration, which as a union of organisations had the goal of pressing for an adequate immigration and integration policy, while at the same time monitoring its actual elaboration. ${ }^{4}$ The Migration Report also saw itself as part of this critical policy monitoring, from the time of its first publication in 2000. Now one can (at risk of exaggerating) state the case as follows: today, the subject of migration and integration no longer requires promoters. Everyone talks about it. The economy and politics, the public and the mass media agree that it is an important topic, and there is now an almost dizzying level of activity in matters of migration and integration around migration researchers, and with their participation. Since Gerhard Schröder's Green Card initiative and the establishment in 2001 of the 
Immigration Commission, a kind of permanent political mobilisation at different federal levels has been brought to bear. With the setting-up of a dedicated federal agency with its own research department, the launch of an integration programme with its own federal competence, the mobilisation of municipalities on behalf of integration, as well as national integration and Islam summits, migration and integration in Germany have risen to the status of political topics that attract the attention of the main policymaking authorities. One can, as a result, register the following fact: the persistence with which the scientific or scholarly community and 'civil society' have made the topic of migration and integration a public issue appears to have paid off, the presentation of problems is now being tackled at all levels of politics - and thus also at the local level.

But can one reasonably consider what has been initiated since the beginning of the 21 st century to be the result of persistence? Ought one to assume that everything depended on the staying power of enlighteners, at the same time understanding the result to a certain extent as the product of a previous domination of a 'rejection of knowledge'? Or does one need to assume - keeping in mind that every idea has its time ${ }^{5}$ - that in politics itself the perceived need for such action must first mature? The question of origin may in this respect appear irrelevant, since in the end the important thing is that sooner or later the reasonably correct course is adopted. But it may nonetheless be worthwhile to ask why the time for integration has now been accepted in politics in general, and more recently in local government politics, and why integration is now the right policy. The starting point for this is a series of observations which do not primarily question the fact that at present potentially important and appropriate measures are being taken in matters of integration in municipalities. However, these observations do challenge the assumption that the 'time for integration' has dawned - be it the result of enlightenment and consultation, be it long overdue insight into structural requirements. For the further development of local integration policy, it may, as a result, be not entirely irrelevant to ask what factors are responsible for the present integration euphoria that can be observed.

1 First, in general terms there are reasons for assuming that politics at whatever level it may reside - does not necessarily become involved as a consequence of scholarly consultation, the insight that results from this consultation, or through application of the knowledge that has been made available. Nor does it make decisions and implement appropriate policies on this basis. The application of scholarly knowledge takes place under the premises of its users. This applies not only but especially in politics, including migration and integration policy. ${ }^{6}$ This does not detract from the significance of the knowledge that has been produced and made available, but it does underline the fact that, in order to understand why the time for integration has come (both as political programme and as symbolic 
politics), we need to understand why its time has arrived in politics and hence also in local politics. ${ }^{7}$

2 What is striking about the current integration euphoria and the related semantic phrase 'integration takes place locally' is that it is far from a new insight. This was already observed by Helmut Stang ${ }^{8}$ in the 1980 s. Municipalities, provided that they have taken into account migration and integration as issues that affect them, have associated this with the fact that, as municipalities, they are obliged to make available to their inhabitants and thus also to foreigners, that is, migrants, the required economic, social and cultural institutions and services. In other words: for municipalities, unless they are in a position to reject migrants, there has been no alternative but integration as a required task. ${ }^{9}$ What then are the reasons for the current mobilisation of municipalities in favour of integration, what is new about it and distinguishes the current process from the previous history of integration policy in municipalities? The answer to this question can be sought on a practical level, and one may ask if something entirely different and new is being offered. Or the answer may be situated at a higher level and be assumed to lie in general social development trends.

3 Such an answer at a higher level has been repeatedly formulated by Rinus Penninx ${ }^{10}$ and others. Penninx interprets the increasing importance of cities to a certain extent as 'fall-out' from the loss of importance of the nation state that results from the globalisation process, from which there results an increase in importance upwards and supranationally toward the EU, and downwards and locally toward towns and cities. In his view, cities are the actual places of integration, and migration for its part is a component and expression of the globalisation process. This is underpinned by reference to the fact that migrants in Europe live predominantly in cities and, at the same time, especially in big cities. ${ }^{11}$ But this situation is not new. And what is meant by cities as 'places of integration'? If cities are, in quite practical terms and without any far-reaching theoretical claims, understood to be spatial accumulations of parallel economic, legal, political, sport-related, familial, educational, etc., events and opportunities, integration should then occur under these very same premises, that is, economic, educational, legal, political, etc., ones. The locality, the place as such, is at the same time not a decisive factor in a social-structural sense. This should be distinguished from the way in which cities or municipalities are spoken of as political-territorial authorities with more or less far-reaching decision-making competence. Integration can be shaped using the means of municipal politics but it cannot, to the extent that it affects the economy, education, the family, etc., be effected or guaranteed politically. A number of decisions that concern the general political, legal and financial conditions of integration in fact lie outside the competence of cities. One may lament this fact, but cities, were the occasion to arise, would hardly have the capacity to make and implement such decisions without the support of 
the nation state. This situation has to do with the proper customisation of policy-related decision-making competences - be it in federal states, be it in unitary states - to the problem of balancing generalised, as opposed to context-sensitive, politics. Whatever one may take to be an appropriate customisation, in the context that interests us here, it is striking that for the actual description of what cities can achieve in terms of integration, even in the case of Penninx, really no new catalogue of tasks and services results from what is in his view the newfound importance of cities. Instead, what is involved is integration in the labour market and education, the stabilisation of families, integration in the housing market, the involvement of migrants in politics and the public sphere, the fight against intolerance and racism, etc., and the question as to what cities as political decision-making contexts are able to contribute in this respect. None of these proposals is really new or has surprise value for municipalities, which are accustomed to problems of integration.

4 If, on the other hand, one looks for an answer to the empirical question of what is new about the current mobilisation of municipalities in favour of integration, here too, nothing substantially new can be discerned, either with respect to what is being recommended to municipalities, or in terms of what they themselves are claiming they want to do. If one takes a look, for example, at the recommendations for action being put forward by the Bertelsmann Stiftung ${ }^{12}$ or the Local Government Association for Municipal Administration (German: KGSt), ${ }^{13}$ which in recent years have been extensively involved in the mobilisation of municipalities on behalf of integration, no indications can be found there of anything that local integration policy should focus upon, anything which lies beyond what has always been the object of local integration policy: language, education, employment and, in addition, a number of fields of activity in the areas of housing and social services with which municipalities are well acquainted. The only new element is the indication that this should be combined with so-called new steering models, in other words, provisions for evaluating and monitoring on the basis of defined sets of indicators, that is, practising integration following methods of modern administration.

5 Certain texts and events sometimes convey the impression that the peculiarity of the local aspect, of cities and municipalities, is being newly discovered. 'Best practice' examples teem with good ideas which, so it seems, could be implemented because context-specific opportunities were put to use and surprising things were achieved. On the basis of this, the conclusion is drawn that it is only a question of taking advantage of locally existing creative potential - it can be done 'locally'. On closer examination, however, this usually turns out to be an effect of the focus on municipalities. If policies to shape the general conditions of integration are dealt with at the federal or state level, it is then, however, not a matter primarily of issues relating to the context-related re-specification of regulations, 
which must always be applied and take effect in such specific contexts, be it in businesses, schools or administrations. The disappointments associated with the welfare state, which relies on being able to bring about integration using general programmes, have greatly reduced the preoccupation and confidence in developing general programmes. If instead one focuses on the creative processes involving the local, context-sensitive 'enacting' of regulations and programmes, it appears as if it were mainly a matter of what takes place 'locally', hence of the particular initiatives of the municipalities themselves, their citizens, businesses and schools, etc. And that is entirely and undeniably correct. Implicit in the slogan 'integration takes place locally' is the reminder that 'locality' implies specificity. Every municipality needs to carry out this very same re-specification of general conditions, adapting them to local conditions. Therein lies, moreover, the very meaning of the subsidiarity principle.

6 But in the case of the discovery of municipalities and cities, are we really dealing with such a process of rediscovery? The idea that it is a matter of the specificity and creativity of the local actually only occasionally crops up in descriptions of successful examples of community integration. For the most part, nothing particularly new or unknown is evoked by the current texts and events on this theme. On the contrary, one is confronted instead with processes of extreme standardisation. Everything that can be said about local community integration - and, as has been shown, it is actually a matter of old topics that have been present in many municipalities for more than twenty years: education, employment, housing, social services, intercultural communication and openness - is being presented in a standardised linguistic design and circumscribed in a semantics in which the key concepts remain the potentials of integration, intercultural openness, concepts, plans, indicators, monitoring or control. When, as it is claimed, it is a matter of the specificity and the specific local potential of cities and municipalities, the standardisation that can currently be recorded and the willingness of local communities to align and present themselves in relation to such standardised forms and the associated expectations of 'community-based integration management' are in any case at odds with this claim.

7 The current willingness of municipalities to take part in the standardisation of the organisational design of their local integration policy is relatively new. Local integration policies since the 1970s have differed significantly from one another. Since then, and through the 1980s and 1990s, they have - though not simultaneously, and in a cumulative and often uncoordinated fashion - rather incrementally constructed local integration infrastructures, combined with corresponding local structures and traditions. Against this background, they persistently and also successfully resisted earlier attempts to standardise them. They have rejected both the numerous attempts to include resident alien advisory councils binding on 
municipalities and the efforts to force local bodies to appoint resident alien and integration commissioners, and such efforts have largely failed. ${ }^{14}$ They put forward revealing and quite understandable reasons for such rejections, which, when examined closely, clarified the specificity of each municipality in opposition to the associated standardisation and setting of organisational structures. They argued that organisational decisions ought to be made dependent on context-specific needs and that general requirements would limit the freedom of action of municipalities to an unacceptable level, and thus limit their constitutionally established autonomy.

8 It could be argued that the contradictions outlined here might be resolved by pointing to the fact that the problems posed by integration today are more intense than in the past, and that this pressure has produced a new understanding of the issues and a willingness to address them. In opposition to this view one should finally point to the following two points: (a) There is no verifiable connection between the scale of immigration to a particular municipality and the latter's commitment to integration policy. In the Federal Republic of Germany there are municipalities which, when seen comparatively, have experienced rather moderate immigration and which have nonetheless devoted considerable resources to integration from an early stage; just as there are municipalities that were greatly affected by immigration but have scarcely undertaken any action. Integration policies and the different forms they assume can instead be explained by the logic of local politics and its organisations. They are less to be understood as reactions to, and the outcome of, surrounding events, such as immigration and settlement in a particular community. Whatever problems were and are associated with this for the particular communities, whatever solutions are aimed at, and whatever means are appropriate, have been developed in the local political organisations themselves against the background of their history and in terms of what is considered to be appropriate and legitimate in political-public terms. The result is the specific institutional design of integration policy in the municipalities. ${ }^{15}$ (b) Neither is there any verifiable connection between the effort involved in local integration policy and the course taken by the integration of migrants itself, measured, for instance, by participation in work and education, the provision of housing, health or the stability of families. ${ }^{16}$ At present we can see that there is considerable public effort being put into institutionalising the belief in the importance and effectiveness of integration policy and that attempts are being made towards a general and standardising orientation of municipalities towards this belief. But this has no empirical basis in the proven effectiveness of local integration policy - beyond the 'best practice' evidence of the 'beautiful passages'. 17

9 Indeed, this cannot be otherwise if one considers more closely what the local integration policy designates. It does not describe a conditional programme which determines what has to take place administratively when 
'a case of integration', identifiable by definite criteria, occurs. This is somewhat different for the Federal Office for Migration and Refugees in the case of newly arrived immigrants. With the registry of their arrival, unless certain exceptional circumstances are present, they set a corresponding integration machinery in motion. ${ }^{18}$ But neither does integration designate a definite purpose programme ${ }^{19}$ in reference to which the output of a local integration policy could be clearly defined - an output by which one could measure what integration policies and corresponding programmes actually achieve. This is first of all due to the fact that local integration policy is not primarily aimed at integration into local politics itself but is instead, using political means, aimed at the integration into other, non-(communal) politically defined and controlled social spheres. It can only influence the latter indirectly, and only in the rarest of cases can it achieve and demonstrate direct influence in one or another direction. The connection between politics and output is thus only a loose one: labour market integration, academic success, health, familial or social harmony in residential areas, etc. In this regard who can conclusively prove the effects of local integration policy? The same thing can also be illustrated by the observation that local integration measures in one case may be presented as evidence of the success of municipal integration efforts; while, on the other hand, they are presented as evidence that the problems and conflicts that occur in schools, city districts or businesses are not caused by the fact that too little effort has been made in terms of integration policy. Organisations that are confronted with so much uncertainty with respect to the effects of their own actions seek support in their institutional design. ${ }^{20}$ They equip themselves in terms of personnel, programmatically, and as far as their forms of internal and external communication are concerned with those elements that have gained internal and public recognition, in other words, that are considered legitimate. The different forms assumed by local integration policy in the history of the Federal Republic of Germany result from this, namely, the differing and far from unified frame of reference used for legitimately shaping municipal policy. This may then also be an indication that this frame of reference has shifted, resulting in the current willingness of municipalities to align themselves toward a largely unified design in the orientation of local integration policy.

If we summarise the points gathered here, it then seems to be completely implausible that the 'time for integration' in municipalities has dawned because they have allowed themselves to be convinced through consultation, because an entirely new situation exists in the cities, or because new, hitherto undiscovered opportunities for action are now available. The time for integration seems to have dawned neither because of pure insight resulting from enlightenment nor because of functional necessity. If it is established that municipalities have, historically, tackled problems of migration and 
integration in a variety of ways and have mostly shown themselves to be resistant to attempts towards uniformity and standardisation, the following questions thus still remain unanswered: why does this situation appear to have changed over the past few years, and why have so many municipalities engaged in processes of standardising their integration policy and allowing themselves to be mobilised for the sake of integration?

At this point we offer the suggestion that this may be interpreted as a process of mainstreaming local integration policy in which communities are pressured externally and internally to acquire a new, standardised institutional design, one which is imposed from the outside as the sole alternative, as it were, but one that is also positively sanctioned, to whose establishment they can contribute during the execution phase, and that provides them with new legitimacy. The essential provider of this design and the engine behind the aforementioned pressure is the welfare and immigration state, flanked by charitable foundations, think tanks and the EU. The community promoters consist, moreover, of private institutions and initiatives, welfare associations, resident alien advisory councils, foreigners' and immigrants' associations, community employees and researchers, so the interests of those involved vary from case to case. In what follows, we would like to explain how this embedding has led municipalities to realign themselves in the sense outlined above.

In the following we first of all deal with the change in the meaning of integration in the welfare and immigration state. We explain how integration ought to be understood as part of the programme of the activating welfare state and, in this context, the new integration policy as a programme of political mobilisation. This provides us with the basis for responding to the question of what importance accrues to municipalities in the reformed welfare state and to their mobilisation on behalf of integration.

\section{Integration Policy - Policy for Migrants as the Normal Clientele in the Activating Welfare State}

'Integration' has become a code word in German federal migration and integration policy. It is at one and the same time a programme and a symbol. In the process, symbolic inflation such as becomes visible, say, in the initiation of the national integration summit in 2006, the promotion of the first ministry for integration in North Rhine-Westphalia as a form of political marketing, or the formula 'Germany, country of integration', hides the structural basis of this gain in importance, namely the changed situation of migrants in the activating welfare state, not only in Germany but also in other north-western European immigration countries. This may be summarised here in note form: ${ }^{21}$ 
- Migrants in the 1950s, 1960s and 1970s in north-western Europe acquired civil and social rights that were formerly considered the privilege of citizens, ${ }^{22}$ and have thus achieved the status of 'denizens' $\left(\right.$ Wohnbürger $^{23}$ ). The countries affected all became in this connection countries of immigration more or less inadvertently (and hence Europe also became one of the world's great immigration regions).

- The irreversibility of this situation has been evident since 1989. Since then, European states have attempted to carry out a renormalisation by granting 'denizens' access to citizenship. In Germany this occurred with the reforms of the law concerning foreign nationals in 1990 and 1993 as well as with the reform of the citizenship law in 2000. At the same time, European countries in the framework of the EU harmonised their migration regimes under the premises of increased control and selectivity (entrance for desirable, potentially capable migrants, rejection of undesirable migration). Integration programmes are part of this process of the growing entanglement of migration and integration policy and of an associated reorganisation of the institutional design of countries. $^{24}$

- Integration does not designate any particular state access to migrants as compared with the rest of the population but rather a tailoring, specifically aimed at migrants, of the general programme of the activating welfare state and the related redefinition of the relationship of service between welfare states and their potential benefit recipients. ${ }^{25}$ The liberalisation of requirements for naturalisation implied the central importance of the integration issue, under the maxim 'supporting and requiring' (fördern und fordern). ${ }^{26}$ The emphasis on the integration issue is an attempt by the welfare state to bring about the normalisation of migrants' status in alignment with naturalisation and the irrefutability of a selective migration policy. ${ }^{27}$ Integration places the focus on the issue of the current and future social-structural positioning of the resident and future migrant population and their associated - particularly economic - productivity and capacity for achieving a self-reliant way of life, independent of social transfers.

The central importance of the integration issue and its symbolic capacity for mobilisation cannot be grasped adequately against this background if it is solely traced back to the notion that there was an 'integration crisis' in the 1990 s or the early $2000 \mathrm{~s}$ - in the sense of a dramatic reduction of migrants' opportunities for social participation. ${ }^{28}$ Migrants' labour market participation, their educational successes, their position in the housing markets, their income levels and the risk of poverty they face always differed from that of the non-immigrant population at the lower end - with significant differences between the various groups of immigrants. In the course of time there have been equalisations as well as intensifications in the level 
of deviation. But this does not explain the central position of the integration issue and its symbolic potential for mobilisation. Two other sets of circumstances are instead significant in this respect. Integration as a form of political semantics ${ }^{29}$ designates the relationship between the welfare state and the individual, be it as a citizen or as a foreigner (migrant). Welfare states are responsible for directing individuals - in keeping with the motto of 'supporting and requiring' - towards integration in those spheres of life such as work, education, the family or health that are important for leading an independent lifestyle. Success or failure at the same time defines their position within the welfare state as (potential) providers of a service or as service (benefit) recipients. With respect to new immigrants, the welfare state makes residence and permanent residence contingent on integration, as clearly laid down in the Immigration Law. For the majority of those migrants who already reside in the country, this option no longer exists. The central importance and the symbolic charge of the integration issue thus results first from the realisation that the migrant population has become permanent and irreversible clients of the welfare state. The welfare state must under conditions of limited productivity address the issue of how it can prospectively guarantee integration under the historically cumulative conditions of an immigration population that is for the most part socialstructurally disadvantaged. ${ }^{30}$ Second, hand in hand with this there is the additional realisation that this migrant population does not represent a quantité négligeable but rather, depending on the age group, constitutes between one fifth and one half of the population and, depending on the way in which it is counted and legally established, is increasing at a relatively rapid pace. Migration becomes, therefore, a structural feature of an increasingly greater segment of the population and it demands, consequently, an adjustment to this situation in terms of institutional design.

Nevertheless, the reliance on integration and integration policy is no German peculiarity, but rather a good deal of what is reflected in the Immigration Law and elsewhere has been copied in essence from other countries, in particular the Netherlands. ${ }^{31}$ It is related to the fact that European welfare states in parallel have been searching since the 1990s for appropriate migration and integration policies, since they all find themselves confronted with the fact that Europe has become an immigration region for the world and since the results of their more or less incremental migration and integration policies correspond only marginally with the erstwhile political aims. This search and the insecurity associated with it are publicly determined by questions concerning the following: the costs and the benefits of immigration; the opportunities, limits and costs of a 'catch-up integration policy' ${ }^{32}$; the degree to which past experiences may be extrapolated to the future; what demands ought to be placed on future immigrants; which, if any, immigrants are desirable; and, finally, how this can be managed and how social integration can be shaped institutionally so 
that a policy of this type, particularly in times of persistent, relatively high levels of unemployment and limited budgetary resources, can be conveyed politically. In other words: the establishment of an integration policy in the German federal welfare state is embedded in this European context of insecurity and of the search for an alternative, legitimising institutional design for such a policy. In the reciprocal copying of models under the label of 'best practice', support is being sought, without this necessarily resulting in the national results turning out to be the same.

Until now, only Germany has laid claim to being a 'country of integration'. Bundled up in this symbolic charge of integration is the institutional uncertainty emanating from the two aforementioned circumstances - migrants as a normal clientele rather than as a special clientele and migration as a probable structural feature of this clientele. This feeling of uncertainty provides, as it were, the source of energy for the mobilisation drive aimed in different directions - particularly at political administrations, their clientele, organisations of trade and industry and education as well as 'citizens'. In the case of administrations, their mobilising orientation toward migrants as a normal clientele is at stake, the related institutional adjustments and the incorporation of this new responsibility into practical routines. In the case of migrants, the orientation towards the expectations associated with welfare state citizenship is involved, in the sense of an internalised, subjectivated citizenship conceived as a bundle of expectations consisting of both rights and obligations. Educational organisations, as with organisations of trade and industry, are mobilised on behalf of integration through the use of appeals and programmes. Citizens are called on to become involved and demonstrate public spirit. This is, alongside the potential practical implications, the symbolic nucleus of the integration summit - as a focusing and intensification of mobilising events of this type and at the same time as a vehicle for their continuation until further notice.

In order to understand what is meant here as well as the related symbolic effort involved, it is helpful to clarify to oneself the fact that from a structural standpoint, social integration and the programmes associated with it in the 'activating welfare state' have in mind access to migrants who are in the process of settling here - a form of access which in a fair and in no way exceptionalist manner establishes a link between migrants and the welfare state, just as it does with the rest of its potential clientele. 'Supporting and requiring', 'rights and obligations': these designate a relationship between the welfare-state service providers and their clientele in which it is demanded of all benefit recipients as individuals, for the most part independently of their nationality, that they provide a quid pro quo, namely that they direct their own behaviour in an independent and marketoriented fashion towards a lifestyle that is as self-reliant as possible, as independent of social subventions as possible. The difference between migrants/foreigners and German nationals has, as a result, lost a good deal of 
its relevance. A person's nationality acts to a decreasing extent as a social 'usher'. Germans and foreigners are equally seen from the perspective of the welfare states in terms of the distinction: productive/competitive vs. unproductive/uncompetitive. The eligibility for benefits in the welfare state must be earned by all individuals, and thus, conversely, the accessibility and acquirability of citizenship occur on the basis of successful social integration. Entirely in keeping with this, the Immigration Commission set up by the federal government in 2000 already stated: 'Integration is a social process in which all those living in a society are continuously involved. The will to integration is absolutely essential. This will to integration is expressed by the fact that each individual on their own initiative seeks to become socially integrated. This applies to natives as well as immigrants. 33

For new migrants, the acquirability of citizenship is thus conditioned by integration policy. Total political inclusion is contingent on the condition of the individual's 'integration capacity', that is, on the economic, cultural and social competencies necessary for participating in the main spheres of life, in particular, the labour market and education and training. But from the perspective of the activating welfare state, it is a matter generally of bringing about such an integration capacity with respect both to immigrants who are already present in the country and to the (inevitably) newly arriving immigrants in the double sense of 'supporting and requiring', in other words, offering immigrants the opportunity to integrate while at the same time demanding that they strive to do so. As stated above, this in no way distinguishes them from the non-immigrant population.

The fact that the central semantic importance of integration and the corresponding mobilisation of administration, migrants, education, economy and citizens to this task are largely symbolic, becomes apparent when one considers that nothing substantively new is occurring at the structural operational level - given that migrants represent the normal clientele of administration. Financial resources have been made available for the promotion of language, education and qualification, for the counselling and stabilisation of families, for the upgrading and maintenance of harmony in certain city districts or for the support of associations. Where necessary, legal tools are employed to advance formal equality and prohibit discrimination (this doesn't necessarily mean that it is prevented). In addition, attempts are made, by means of symbolic communication, to mobilise above all those organisations such as administrations, schools, businesses, on the one hand, and the migrant and non-migrant population, on the other, to participate in integration. Under changed and symbolically enhanced organisational conditions, with greater intensity and public staging, what is done is what has always been done (if anything at all has been done): in practical terms, coping with everyday tasks in diversified organisations charged with integration in politics and administration, education and 
training, social work, employment, sport and health. But in doing so, those actors involved show, through a symbolically staged reorganisation of the institutional design, what integration policy has promised, namely efforts toward integration and the prospect of integration.

In order to understand the process in this manner, one needs to bear in mind that, since the first Immigration Commission and finally with the passage of the Immigration Law, the setting-up of an explicit policy of integration was, quite literally, a bold promise. The reason is that social integration in the different areas of the economy, law, education and training, health and religion, takes place in a variety of ways. The successes and failures of social integration arise in distinctive ways ${ }^{34}$ (not only in the case of migrants) and show themselves to be especially unwieldy in relation to political attempts to control them and hence also in relation to an integration policy aimed at migrants. ${ }^{35}$ And in the course of realising that migrants have become permanent clients of the welfare state, why has the prospect suddenly opened up of an entirely new repertoire of action beyond what has already been done up to this point? Today, politics and the state generally operate on the assumption of a restricted capacity to control and intervene. Society has shown itself in its various subdivisions and organisations to be too heterogeneous, mobile and incalculable. ${ }^{36}$ Against this backdrop, too, integration policy indeed sets out surprisingly strong political claims about what appears to be its big plans.

In response to the unavoidable designation of migration and migrants as a problem and as an obligation of the welfare state, integration is being conceived both politically symbolically as a value (the self-reliant lifestyle) and as a problem (the burden on the welfare state). Yet how can integration, understood as both a value and a problem, be practically and publicly implemented in policy? ${ }^{37}$ What can be achieved when there is no longer any doubt that something must be undertaken in order to fulfil visibly an expectation such as that of integration, a factor which nonetheless cannot be measured by any obvious political output? One possibility for solving impossible tasks such as the fulfilment of diffuse (self-produced) expectations is to view them on the basis of existing and available means and recognised solutions: in other words, to centre the problem of integration around the existing means and solutions and to supply them with a new institutional design, thus rendering them determinable. ${ }^{38}$

The Immigration Law and the main task of integration set forth there; the associated conversion of the former Federal Office for the Recognition of Foreign Refugees into the Federal Office for Migration and Refugees (German: BAMF) as the body responsible for the implementation of language and integration courses; the central position of language as the basic prerequisite of integration: all this marks out integration as the symbolic centre of a policy that at the same time has provided itself with a new institutional design. Offices such as the BAMF and the Immigration Authority, 
which formerly dealt primarily with the rejection of migrants and their claims, are now responsible for integration and reinvent themselves as 'competence centres' for migration and integration. Comprehensively arranged language courses as a legally based federal programme also demonstrate that something is being done, just as is the case with the proliferating reporting services for migration and integration in the federal government, ${ }^{39}$ in the Länder and ideally in municipalities as well, that is, in the 'monitoring of expectations'.

On closer examination, however, the establishment and realisation of integration courses by the BAMF or the setting-up of initial consultations for migrants represented no great break with the previously applied integration policies, with their services such as language courses or social counselling services. Precursor structures were used and reorganised. Similar to the way in which the Immigration Law as a whole combined existing regulations, introduced few new elements for the opening-up of immigration options and provided for merely moderate changes in the Residence Law, in the regulation of so-called 'existing cases' as well as in the handling of forced migrations and asylum migrations, here too, beyond the restructuring of organisational competences and the legal inclusion of new immigrants in integration programmes, no radical break with the past occurred but instead an expansion of the previously applied integration policy in the Federal Republic of Germany - albeit in an altered, symbolically charged design.

This new integration policy is being symbolically staged as a new beginning and as a break with the past. In opposition to the everyday experience of déjà vu and instances of organisational turbulence, which result from changed competences, problems of coordination and newly deployed procedures, there was and is the emphatic communication of a new beginning. Integration is formulated as 'society's principal challenge today', and against this backdrop the importance of task formulation is underlined. Integration has become a kind of contingency-coping formula for migration and integration policy and all measures prompted or enabled by it. ${ }^{40}$ This symbolic policy of integration had its provisional apex in the National Summit on Integration.

This came about in reaction to an entirely unintended effect of symbolic policy: the rhythm of politics demands rapid results. The symbolically charged programme of integration focuses public attention on migrants and their living conditions. Under the influence of events in the Netherlands (the murder of Theo van Gogh) and in France (the suburban riots in the autumn of 2005), the media's seismographs were directed at potential social catastrophes: at 'parallel societies', at honour killings and forced marriages, fundamentalist organisations or marginalised and potentially violent male adolescents. For practitioners and academics who had been dealing for years with issues of migration and integration, nothing really new has been 
said or uncovered. However, prompted and put into focus by an exacting integration policy, these events were observed with great attention and conveyed by the media primarily with a focus on social catastrophes. ${ }^{41}$ The 'failure of integration', however, seemed in the meantime to be obvious to the public. More moderate voices were viewed to a large extent as playing down the problems.

In this situation the Chancellor initiated the Summit on Integration, from that time on a regularly occurring major public event intended to mobilise 'society' on behalf of integration and in whose framework the National Integration Plan (NIP), involving all levels of politics (the federal government, the Länder and municipalities), migrants' representatives and all relevant segments of society in ten working groups, was developed. ${ }^{42}$ The drawing-up of the plan itself as a series of events, together with the resulting National Integration Plan, attests to the organisational and symbolic effort being placed on generating public commitment. And so it is stated in the NIP: 'What began in July 2006 as a meeting in the Federal Chancellery has in recent months sparked a lively development in our society. In terms of integration policy, too, Germany is experiencing a sense of a new era about to dawn' (p. 9). And one of the two guidelines of the NIP states: 'To demand of every person self-commitment in his or her area of responsibility, since everyone can contribute something to the success of integration in Germany' (p. 10).

The political event called the 'National Integration Plan' is not yet finished. Evaluations and stock-takings are planned. What has been achieved and what has not been achieved are to be the object of debate. Critical reactions have repeatedly noted that the commitments contained in the NIP are without real substance. This is a highly contentious issue. More significant in our context is that the NIP offers almost nothing that is substantively new on the question of how integration policy may be shaped and how integration can be promoted. Why should this be otherwise, given that the terrain is familiar and that an extensive repertoire of recognised methods and solutions is available? ${ }^{43}$ At its core the NIP demands more effort, it requires a commitment to the belief that integration requires a specified set of tasks, and in this context it pushes for the institutional redesign of policies to further integration to the forefront of public awareness.

\section{Local Integration Policy as Institutional Design}

What does this have to do with municipalities? What role is ascribed to them in this process, and how is this process related to the commitment of municipalities to the task of integration as cited at the outset, and to their alignment towards the standardised expectations attached to the institutional design of this policy? There are three possible responses to this question: 
1) Municipalities are the main bodies responsible for public administration in the federal system of the Federal Republic of Germany, which in particular look after tasks conferred upon them by the federal government and the Länder; 2) in the reformed welfare state an altered status has been conferred upon municipalities; and 3) the formula 'integration takes place locally' builds bridges and opens up opportunities for mobilising municipalities.

1 Municipalities are the main bodies responsible for public administration in the federal system of the Federal Republic, a level of administration which oversees numerous tasks conferred upon them as well as tasks determined on the basis of the autonomy given to local communities. Prior to any further specification, these administrations and their staff are the addressees of this mobilisation for integration, through which they, in structural terms, are being adapted to the generalised, (nearly) unconditional inclusion of the migrant clientele. ${ }^{44}$ This alone, however, does not adequately explain the aforementioned willingness of local communities to commit themselves to engaging in integration, through reinforcing and parallelling federal mobilisation efforts.

2 Municipalities have become the focus of political mobilisation in favour of integration because a prominent position has been structurally assigned to them in labour market policy reforms (Hartz I-IV) and in the Immigration Law. By this, too, it can be recognised that integration policy has to be seen as part of the reform programme of the activating welfare state. This and the already mentioned equal treatment of migrants and natives from the perspective of the welfare state become clear when the integration courses are set in relation to the systematic changes that have resulted from the Hartz reforms. The replacement of the previous unemployment assistance by the Unemployment Benefit II and the inclusion of all previous recipients of social assistance, who as employable individuals are now available to the labour market, places all individuals who receive benefits and are no longer entitled to unemployment benefits in the same position relative to the state. The formula 'supporting and requiring' refers to the limitation being placed on their entitlement to reject the requirement that they take up work that has been procured for them based on their status, that is, with reference to their education, previous occupational status and income expectations. ${ }^{45}$ The entitlement to support is hence only recognised insofar as the requirement that people take up work is complied with, detached from any previously acquired occupational status. Integration courses are also primarily aimed at enabling new immigrants as well as those migrants who are considered 'in need of compensatory integration' from a linguistic and knowledge-related viewpoint to align themselves early on with lifestyle requirements in the context of immigration and in particular with requirements of the labour market. This becomes evident in structural terms as well from the organisational entanglement of the 
integration programmes with the Federal Employment Agency or the Work Associations (Arbeitsgemeinschaften).

As a result of these changes, the burden on municipalities has, on the one hand, been lessened in two respects. With the replacement of the previous unemployment assistance by the Unemployment Benefit II and with the inclusion of all previous recipients of social assistance who, as employable individuals, are now available to the labour market, this new service provided by the Federal Employment Agency has brought to a close the communalisation of unemployment problems, which the municipalities had been protesting against since the $1980 \mathrm{~s} .{ }^{46}$ In addition, the majority of those migrants who are not eligible to receive unemployment benefits now fall under the jurisdiction of the Federal Employment Agency and, as a result, the previous communalisation of the follow-up costs of immigration has also now been corrected. ${ }^{47}$

On the other hand, municipalities are incorporated into the associated organisational arrangement in such a way that they now have devolved responsibilities for shaping local integration policy, responsibilities which have resulted both from the Immigration Law and from the Hartz reforms. On the basis of the integration courses offered by the BAMF in coordination with the Aliens Authorities for which they are responsible and based on their newly acquired position in the Consortium, local communities can influence which bodies within their reach are recognised or recommended to migrants, which migrants are included in the integration courses and how the initial consultations for migrants are shaped. In the framework of the prescribed Consortium, but also in the so-called optional municipalities, they have competences and opportunities for a community-specific organisation of job placement in which they can take into account immigrants, if necessary by considering integration-specific points of view. These opportunities must be seized, however, and this requires that municipalities be mobilised to grasp them and that the problem of integration be couched in terms of the inclusion of the local migrant population as part of the normal clientele. This mobilisation is not the inevitable result of their previously changed status as outlined above.

3 However, mobilisation is not left up to local coincidence either. The 'Successful Integration Is No Accident' competition, jointly initiated by the Interior Ministry and the Bertelsmann Stiftung, is formulated to some extent in opposition to this view and presents the results of this competition as a model and as a mobilising challenge. ${ }^{48}$ Similar initiatives aimed at municipalities are derived from the project 'Immigrants in the City', which has been run by the Schader-Stiftung since $2004,{ }^{49}$ but also from the federal-Länder programme 'The Social City' ${ }^{, 50}$ and other campaigns.

The mantra informing such programmes - 'Integration takes place locally' - has considerable plausibility and unifying potential. ${ }^{51}$ This formula expresses the subsidiarity perspective as regularly asserted by municipalities 
especially in defence of their political autonomy. It restricts, on the other hand, claims on the federal government and the Länder. Furthermore, it finds support in the fact that social integration and its consequences occur in a locally differentiated way and in the fact that a large number of the practical political programmes involving integration are set up, as far as their customisation is concerned, to be context-specific and apply in a community framework. Support programmes in the areas of education, training and employment, the family, housing and city districts that are aimed at migrants are in many cases designed to be complementary and adding value, and act as variants of social work. Their institutional design is locally ${ }^{52}$ and community oriented, although the support programmes themselves are being set up by the Länder, ${ }^{53}$ the federal government, the $\mathrm{EU}^{54}$ or foundations. ${ }^{55}$ Mobilisation for integration, seen as the symbolic diffusion and implementation of the belief in the possibility of integration through commitment, thus finds points of contact in municipalities both by connecting with the communities' self-image through the formula 'integration locally' and by means of the institutional design of the available practical integration measures, for which corresponding funds have been provided.

Related to this are the expectations about the symbolic and organisational direction of such local integration programmes, which some municipalities quite rapidly set up as explicit political programmes, and which they have quite aggressively seized upon and promoted - as can be seen in cities such as Stuttgart, Frankfurt, Munich, Solingen, Essen or Wiesbaden. ${ }^{56}$ A semantic repertoire is made available to municipalities for the description of problems, appropriate solutions and effective means, and in this context administrative forms of rationality - from monitoring to indicators to evaluation offer a repertoire with which they may apply for funds for legitimate integration measures, and have good prospects of receiving them. This includes their increasing orientation toward conceptual and organisational key concepts and maxims as core elements of the institutional design of the new integration policy: 'integration as a cross-sectional task'; declaring integration to be a 'top-level concern'; setting their sights on a 'holistic municipal integration concept' and 'integration management', based on regular integration reports, evaluation and 'indicator-based monitoring'; 57 the understanding of migration and integration in terms of 'potential' (and less as a problem); ${ }^{58}$ the addressing of migrants as 'subjects' and from the perspective of 'participation'; the 'bundling of activities' and the 'creation of networks'; the 'intercultural opening-up of administration' and the 'rejection' (or more strongly: fight against) discrimination and racism'. ${ }^{59}$ Contained in this semantics is the double offer of (a) a procurement of resources, on the one hand, and (b) recognition and legitimacy, on the other.

$A$ With regard to social policy, many municipalities have learned since the 1980s how to procure resources through third parties, in light of the crisis of public budgets and of a sizeable stock of permanent and 
unsackable employees, resulting in high follow-up costs and limitations on flexibility. They have built up support networks, through which resources for dealing with local tasks in different social areas could be procured through external intermediaries, without the need for entering into the long-term or irreversible obligations associated with permanent positions and the tying-up of community resources. Insofar as they have cultivated a longer tradition of integration work, this approach can be applied in that area, too. Conversely, the existence of numerous private institutions, ${ }^{60}$ which are increasing in number, has meant that these institutions are undertaking corresponding efforts toward resource procurement. These private institutions confront the municipalities, in alliance with churches and in some cases alien advisory councils and migrant organisations, but also with the support of municipal employees, who view this as an opportunity for the growth of their department or task area, invoking programmes and initiatives of the EU, federal government, the Länder and private foundations, which have corresponding expectations and claims. They thereby encourage the communities to become active in the area of integration policy and to adapt their administrations for this purpose. In this respect, they represent the potential for mobilising municipalities from the inside by contributing to delegitimising their - as the case may be - historically and incrementally achieved solutions ${ }^{61}$ in opposition to the nationwide communicated design of modern integration policy and its orientation.

$B$ In light of these internally as well as externally triggered processes which result in the erosion of the legitimising bases of their policy to date, the offer of a realignment in the design of local integration policy promises municipalities the prospect of a recognised legitimate institutional constitution and thus the possibility of regaining their stability. This redesign along the lines of copying and 'best practice' indeed offers them no guarantee that integration will succeed - through management, monitoring, nor evaluation - but it does provide them with institutional security in view of the uncertainty that surrounds integration policy. The circumscription of the New Management Model to one of local integration policy, such as that which the Local Government Management Association (KGSt) has taken on board for several years now and imparted in numerous training sessions, continuing education sessions and community projects, ${ }^{62}$ does not eliminate the aforementioned insecurity surrounding integration. This insecurity results from the fact that policy is unable to effectively steer those areas of integration which are significant for individuals' way of life above all employment, education, the family. ${ }^{63}$ On closer examination, the proposed methods for monitoring integration and for managing local integration $^{64}$ demonstrate above all that what the municipalities have undertaken - proceeding on the basis of the (means- and concept-based) selective observation of their environment and taking into consideration the available legitimate means and solutions, how they have observed this 
reflexively from the standpoint of an effective and efficient use of means and have continually adjusted this in the manner of their reporting. Whether this serves the purposes of integration is and remains uncertain, but it does provide some formal rationale to alterations in the institutional design of local integration policy. This, combined with the orientation toward 'best practice', provides institutional legitimacy through alignment with what is considered appropriate and effective, without it being altogether clear what this achieves and although it is known that the transformation of 'best practice' to other contexts results in experiments with an uncertain outcome. In other words: security and legitimacy are drawn from an institutional design that offers a formal rationality that mirrors other comparable organisations, in terms of the public communication of commitment and in the orientation towards measures that bring about what is generally recognised as appropriate and effective - 'best practice'. This allows one to deal with the irrevocable uncertainty associated with political organisations and programmes, which, like integration policy itself, set targets which need to be achieved in social contexts but which cannot be determined by political means, so that the means and solutions established to reach these targets have only a loosely coupled relationship with the stated goals. The currently observable willingness of municipalities to accept the standardisation of their integration policy and the public demonstration of their commitment thus has its basis in the fact that this changed institutional background, publicly recognised as legitimate, gives them an acceptable framework for dealing on a daily basis with the uncertainty of integration policy.

\section{Conclusion}

The account given here has examined the basis for the willingness of numerous municipalities to adjust and align their integration policy. What does this account imply about what can be done, in the context of the debate surrounding integration policy? Doesn't this type of critical account inevitably lead us to the conclusion that, from a practical standpoint, such observations really cannot be taken into account if one wishes to avoid rendering oneself incapable of acting politically? On the other hand, however, one hardly runs into serious opposition when referring to such a perspective in the context of expert sessions, education and training opportunities or in public debates. 'Insiders' are familiar with the latent foundations of the game - and for that very reason it may be that they have need of the 'hidden protection' that results from non-treatment of the topic. But this is not necessarily so. It can also be the case that integration policy may profit from more knowledge about its contingency, since it can be organised and, if necessary, revised more calmly without the presence of exaggerated 
claims and complaints about unfulfilled expectations. We conclude this essay with a few concluding observations on this point.

The uncertainty and riskiness of integration are hardly new insights; on the contrary, it is the very foundation of the welfare state's origins as a means of dealing with this risk which, particularly in Europe (in contrast with, say, the US), pervades society in the form of far-reaching processes of institutionalisation. International migration reminds us once again of the riskiness of integration processes. ${ }^{65}$ Integration policy is an option for dealing with this, which lies close at hand but which neither annuls its uncertainty nor is able to guarantee integration itself.

If one relies on such a policy, as has been shown, it is only logical then that the welfare state should not enter into any special relationship with migrants. The peculiarity lies solely in the issue of the specific conditions affecting migrants or their environment, in the context of their attempts to integrate. These conditions ought to be taken into account in the shaping of the integration policy that is tailored to migrants, assuming one accepts an unchanged general objective: integration as the enabling and obligatory expectation of a self-reliant lifestyle. Such special conditions involve cultural features such as language, education, occupational qualification, skills, knowledge and faith, the adjustment of familial and other social relations on the part of the migrants, but also opportunities or barriers which they run up against in the particular immigration context that is relevant to them and which can run the gamut from the institutional hurdles of nonrecognition of acquired extraterritorial qualifications and the associated monopolisation of occupational markets to the insinuations involving limited educability or cultural prejudices and just plain racism. The various options for reacting to these issues by political means have been known for some time. With money, politics can apply measures for the promotion of language, education and qualification, for the counselling and stabilisation of families or for the support of associations. By legal means it can advance the cause of formal equality and prohibit (not necessarily prevent) ${ }^{66}$ discrimination. And by means of symbolic communication it can mobilise above all organisations such as administrations, schools, businesses as well as the migrant and non-migrant population to participate in integration. This is what is currently happening, and we have tried to show that these efforts have gained resonance in municipalities.

If one relies on integration policy as thus described, one can expect the following implications: for the time being, one must believe in such an approach, and also deploy adequate resources for implementing it. If it is a matter of winning over all federal levels and particularly municipalities to this policy, then in addition to symbolic mobilisation one must also increase the available resources. In doing so, one may realise that the numerous practical programmes and support measures are an integral part of the history of integration and its results to date, and that in many cases old 
programmes are being set up with a new design. It may be that this is not harmful but, in view of the 'sense of a new era about to dawn in Germany, the country of integration', in this case disappointments, which quickly arise in daily business given the slow process of integration, are bound to occur. One can protect oneself against this by remaining aware of the uncertain nature of integration, without at the same time having to abandon attempts at constantly improving things, attempts which should of course be based on observation, indicators and evaluation. The appropriate control procedures of evaluation and monitoring, such as they have also penetrated the domain of integration policy, provide, on the one hand, a certain workmanship-like sense of security. But, at the same time, they also furnish this domain with a myth of rationality which for its part runs the risk of bringing about a sense of false security surrounding the effects which should be or have been produced while, on the other hand, concealing uncertainties and insecurities in the output design of the relevant reporting and evaluation procedures.

Attempts at equality (as well as attempts to symbolically mobilise political administrations, trade and industry, education as well as of the population of migrants and non-migrants on behalf of integration) are aimed, on the one hand, at the total inclusion of migrants, their recognition as a normal clientele and the expectation that they should participate in this process through subjectification. On the other hand, in the case of non-migrants there is an expectation that they, in their roles in politics, administration, education and the economy as well as their daily lives, should bring about this equalisation and equal treatment through 'intercultural openness'. This much is evident and is as such constantly being alluded to, especially by migrants: in concrete terms, this form of mobilisation for the 'normal migration case' underlines the special nature of migrants and thus serves paradoxically to underscore this special status.

Finally, it should be expected that the processes of institutional redesign go hand in hand with phenomena of loose coupling. ${ }^{67}$ The level of public representation given to local integration and integration policy does not coincide with what is decided upon locally, and the premises that underlie the actions of the various administrations. And representations and decisions do not determine daily behaviour: rather, the latter shapes the margin of manoeuvre created by (symbolic) representations and decisions, from the viewpoint of how practitioners come to terms and deal with pertinent problem situations. This loose linkage between the way integration policy is represented, the decisions made and actions taken is unavoidable. No organisation can get by without a certain amount of hypocrisy, as Nils Brunsson has called it. When municipalities announce at numerous public events and campaigns that they have adopted a new design, these different levels need to be disentangled in order to determine what is occurring. The forms of self-presentation that occur in the increasingly standardised forms 
of reporting, observing and evaluating occasionally give the impression in light of these circumstances - of an attempt to disguise these unavoidably loose couplings by means of movable walls. These forms of selfpresentation derive their effectiveness from the institutionalisation of such standardised forms of description and thus lay the foundations for the risk of immunisation against deviant forms of observation. This, too, one must be aware of.

But if this is so, one must assume that, in the case of future integration policy, protection for its foundations - in view of the foreseeable problems resulting from a symbolically charged integration design, the anormalisation of migration through a rhetoric of normalisation or the phenomena of a loose interface hidden by a unifying emphatic rhetoric - will be of little avail. Irony in this case appears to be more promising, since it is aware of weaknesses and communicates decisions in the light of other possibilities, without laying claim to an infallible understanding of how things occur. But not every process which is not fully understood can be left unattended until such time as it is understood: integration policy will be continued until further notice. And for this reason municipalities may also seize the opportunities that have been outlined above. They may then, as we have suggested in another context, ${ }^{68}$ become integration moderators, and they may be able to achieve part of what Häußermann and Kapphan as well as Pavković have discussed in this volume. ${ }^{69}$ Remaining in the dark is only one option. Irony is another, one which is perhaps less susceptible to disappointments - and for that reason has no need to insist on breaking with the past and on (in any case unlikely) radical changes in order nonetheless to be serious about how it confronts or acts upon criticism and divergent views.

\section{Notes}

I Federal Association of Local Authorities: Article on Working Group 5 'Integration on Site', p. I, http://www.dstgb.de/index_inhalt/homepage/artikel/inhalt/brennpunkte/ integration/integration_vor_ort.pdf

2 The present text is based on an idea that the author developed in a lengthy discussion with Bernhard Santel, whom he therefore regards as a kind of intellectual coauthor, without making him responsible for the inadequacies of this text. I would like to thank him for this. Next, I must thank Andrea Lenschow for checking and improving the text.

3 Klaus J. Bade (ed.), Das Manifest der 60. Deutschland und die Einwanderung, Munich I994.

4 Cf. the homepage of the Council on Migration (German acronym: RfM): http:// www.rat-fuer-migration.de.

5 And then, when its time has come, according to Victor Hugo, it is more powerful than entire armies.

6 Cf. in general Niklas Luhmann, 'Theoretische und praktische Probleme der anwendungsbezogenen Sozialwissenschaften', in: id., Soziologische Aufklärung, v. 3, 
Opladen I98I, pp. 321-334; Ulrich Beck \& Wolfgang Bonß, Weder Sozialtechnologie noch Aufklärung? Analysen zur Verwendung sozialwissenschaftlichen Wissens, Frankfurt am Main. 1989; Matthias Wingens, Soziologisches Wissen und politische Praxis. Neuere theoretische Entwicklungen der Verwendungsforschung, Frankfurt am Main/ New York 1988, and, on migration research, Peter Scholten, Constructing Immigrant Policies: Research-Policy Relations and Immigrant Integration in the Netherlands (1970-2004), Enschede 2007, as well as the excellent study by Christina Boswell, The Political Uses of Expert Knowledge. Immigration Policy and Social Research, Cambridge 2009, on the application of migration research in Germany, Great Britain and the EU.

7 Its time had long since arrived in science and scholarship (concerning this, see Michael Bommes, 'Migration and Migration Research in Germany', in: Ellie Vasta \& Vasoodeven Vuddamalay (ed.), International Migration and the Social Sciences. Confronting National Experiences in Australia, France and Germany, Basingstoke 2006 , pp. I43-22I), but, much to the regret of scholars, for a long time this failed to impress politicians.

8 Cf. Helmut Stang, Ausländerintegration in der kommunalen Praxis. Ein Leitfaden für Kommunalpolitiker und Verwaltungsbehörden, Cologne I982.

9 For more on this, see Michael Bommes \& Ulrich Rotthoff, 'Europäische Migrationsbewegungen im kommunalen Kontext', in: Konrad Adenauer Stiftung (pub.), Kommunen vor neuen sozialen Herausforderungen (Interne Studien Nr. Ioo), St. Augustin I994, pp. 93-I48; Michael Bommes, 'Die Rolle der Kommunen in der bundesdeutschen Migrations- und Integrationspolitik', in: Frank Gesemann \& Roland Roth (ed.), Lokale Integrationspolitik in der Einwanderungsgesellschaft. Migration und Integration als Herausforderung von Kommunen, Wiesbaden 2009.

Io Cf. Rinus Penninx, 'Migration and the City: Local Citizenship and Integration Policies', in: Maria Lucinda Fonseca (ed.), Cities in Movement: Migrants and Urban Change. Centro de Estudos Geográficos, University of Lisbon, Lisbon 2008; id., 'Lokale Integrationspolitik in Einwanderungsgesellschaften', in: Gesemann \& Roth (ed.), 'Lokale Integrationspolitik in der Einwanderungsgesellschaft'; id. et al. (ed.), Citizenship in European Cities: Immigrants, Local Politics, and Integration Policies, Aldershot 2004.

II Nevertheless, the situation in individual European states varies considerably, and Germany is characterized by the fact that, on the one hand, no metropolises such as London, Paris and Istanbul are found here, on the other by the fact that migrants do indeed live more in the cities than non-migrants but still also to a great extent in medium-size and small cities and in the countryside; regarding this, cf. Karen Schönwälder \& Janina Söhn, Siedlungsstrukturen und residenzielle Segregation von Migranten in der Bundesrepublik Deutschland (WZB Discussion Paper SP IV 200760I), Berlin 2007, and id., 'Siedlungsstrukturen von Migranten und Migrantinnen in Deutschland', in: Verbundpartner 'Zuwanderer in der Stadt' (pub.), Handlungsfeld: Stadträumliche Integrationspolitik. Ergebnisse des Projektes 'Zuwanderer in der Stadt', Darmstadt 2007, pp. 73-91.

I2 Bertelsmann Stiftung \& Federal Ministry of the Interior (pub.), Erfolgreiche Integration ist kein Zufall. Strategien kommunaler Integrationspolitik, Gütersloh 2005.

I3 Alfred Reichwein \& Stephanie Vogel, Integrationsarbeit - effektiv organisiert. Ein Handbuch für Kommunen, Ministry for Health, Social Services, Women and the Family of the State of North Rhine-Westphalia, Düsseldorf (n.d.).

I4 The obligation to establish resident alien advisory councils in communities, as some Länder, Hesse or North Rhine-Westphalia, for example, provide for in their municipal codes, does not derive from the consent of the communities or their central organizations. Efforts to impose resident alien or integration commissioners on the 
communities, such as has been aimed at in the meantime by the federal conference of these commissioners, failed on the other hand. For detailed evidence of this, cf. Michael Bommes, Interessenvertretung durch Einflu $\beta$. Ausländervertretungen in Niedersachsen, Osnabrück I99I; id., Ausländerbeauftragte in den Kommunen. Eine Untersuchung zu ihrer Funktion, ihren Aufgaben und ihrer Stellung in den kommunalen Verwaltungen, im Auftrag der Beauftragten der Bundesregierung für die Belange der Ausländer, Institut für Migrationsforschung und Interkulturelle Studien, Universität Osnabrück 1998 (unpublished).

I5 Regarding this, see Michael Bommes, 'Die politische "Verwaltung" von Migration in Gemeinden', in: Jochen Oltmer (ed.), Migration steuern und verwalten. Deutschland vom späten 19. Jahrhundert bis zur Gegenwart (IMIS-Schriften, v. I2), Göttingen 2003, pp. 459-480.

I6 The same thing can also be observed more generally. Philip Muus, for example, has pointed out that in Europe in those countries that employ the greatest number of programmes for labour market integration, the rate of unemployment is the highest - and vice versa: cf. Philip Muus, 'Migration and Labour Markets. Do We Need a Common European Labour Migration Policy?' Paper presented at a seminar organised by the Departimento di Sociologia \& Ricerca Sociale, Università degli Studi di Trento 2005 .

I7 In his sociology of music, Adorno condemns listening to 'beautiful passages' precisely on the grounds that in so doing one misses the structure of the whole; cf. Theodor W. Adorno, Einleitung in die Musiksoziologie, Frankfurt am Main 1962.

I8 Without being able to assume that newly arrived immigrants, after having passed through this programme, are necessarily 'integrated'.

I9 For the distinction between conditional and purpose programmes, see Niklas Luhmann, 'Politische Planung', in: id. (ed.), Politische Planung. Aufsätze zur Soziologie von Politik und Verwaltung, Opladen I97I, pp. 66-89.

20 Cf. Richard W. Scott \& John W. Meyer, 'The Organization of Societal Sectors', in: Walter W. Powell \& Paul J. DiMaggio (ed.), The New Institutionalism in Organizational Analysis, Thousand Oaks, CA I99I, pp. I08-I40.

2I For a more detailed examination, see Michael Bommes (2003), "The Shrinking Inclusive Capacity of the National Welfare State: International Migration and the Deregulation of Identity Formation', in: Grete Brochmann (ed.), The Multicultural Challenge (Comparative Social Research, v. 22), Oslo 2003, pp. 43-67; Klaus J. Bade \& Michael Bommes, 'Introduction: Integrationspotentiale in modernen europäischen Wohlfahrtsstaaten - der Fall Deutschland', in: id. \& Rainer Münz (ed.), Migrationsreport 2004. Fakten - Analysen - Perspektiven, Frankfurt am Main/New York 2004, pp. II-42.

22 Rogers Brubaker (ed.), Immigration and the Politics of Citizenship in Europe and North America, Lanham/London I989; James F. Hollifield, Immigrants, Markets and States. The Political Economy of Postwar Europe, Cambridge, MA I992; Yasemin Soysal, Limits of Citizenship. Migrants and Postnational Membership in Europe, Chicago/ London 1994 .

23 Tomas Hammar, 'State, Nation and Dual Citizenship', in: Brubaker (ed.), Immigration and the Politics of Citizenship, pp. 8I-95.

24 For clarification: the previously outlined structural implications of immigration into the welfare state, the acquisition of the status of denizens and the accompanying irreversibility all transform the contingency spaces of politics. They do not, however, force functional integration. This is rather suggested on the basis of the institutional design of welfare states in Europe - in contrast to the US, which links immigration permits with a number of prerequisites that in advance prove the integration capacity of potential immigrants but which, in all other respects, leave them on their 
own. The continental European welfare states, on the other hand, still organise, as part of their activating reforms, the release of their citizens into the marketplace in the manner of the continental 'caring state' with a considerable amount of paternalistic effort; cf. Abram de Swaan, Der sorgende Staat. Wohlfahrt, Gesundheit und Bildung in Europa und den USA der Neuzeit, Frankfurt am Main/New York I993.

25 Bommes, The Shrinking Inclusive Capacity of the National Welfare State.

26 Christine Weinbach, 'Europäische Konvergenzen: Zur Restitution von Staatsangehörigkeit in Deutschland, Frankreich und Großbritannien', in: Berliner Journal für Soziologie, 15. 2005, Heft 2, pp. 199-218.

27 Irrefutable in the sense that any policy, even a non-policy, is a decision - and be it only the decision to make no decision which characterized the migrant policy situation of the Federal Republic in the I980s and I990s.

28 This is the view, for example, of Boswell, The Political Uses of Expert Knowledge, who assumes such a crisis with no more evidence than the background of the transformation of migration policy in Germany.

29 A distinction must be made between the sociological meaning of what is designated by the term 'integration' and the political semantics of integration. The degree of social integration (not only) of migrants describes, in sociological terms, essentially the question of the extent to which they succeed in taking part in those social spheres that are significant for an individual's way of life, that is, access to work, education and training, housing, health, the legal sphere, politics, the mass media and religion. For further discussion, see Michael Bommes, Erarbeitung eines operationalen Konzepts zur Einschätzung von Integrationsprozessen und Integrationsmaßnahmen. Gutachten für den Sachverständigenrat für Zuwanderung und Integration, Osnabrück 2004, http://www.bamf.de (Publikationen Themenbereich Migration). In this text we are dealing with the political semantics of integration.

30 In this context, migrants have become the subject of public discourse both as a symptom and as a cause of the welfare state's underachievement. In this connection see Bade \& Bommes, 'Einleitung: Integrationspotentiale in modernen europäischen Wohlfahrtsstaaten - der Fall Deutschland', in: Migrationsreport 2004.

3I Ines Michalowski, 'Qualifizierung oder Selektion? Die Dynamiken der Neuformulierung einer Integrationspolitik', in: Anne Walter, Margarete Menz \& Sabina De Carlo (ed.), Grenzen der Gesellschaft? Migration und sozialstruktureller Wandel in der Zuwanderungsregion Europa (IMIS-Schriften, v. I4), Göttingen 2006, pp. I43-I62; id., Integration als Staatsprogramm: Deutschland, Frankreich und die Niederlande im Vergleich, Münster 2008; id., Karen Schönwälder \& Janina Söhn, Sprach- und Integrationskurse für MigrantInnen. Erkenntnisse über ihre Wirkungen aus den Niederlanden, Schweden und Deutschland (AKI-Forschungsbilanz 3), Wissenschaftszentrum Berlin für Sozialforschung (WZB), Berlin 2005.

32 Cf. Klaus J. Bade, 'Nachholende Integrationspolitik', in: Zeitschrift für Ausländerrecht und Ausländerpolitik, 25. 2005, Heft 7, pp. 217-222.

33 Report of the Independent Commission on Immigration, Berlin, 4-7-200I, p. 200; for the reference to this quotation I am indebted to Christine Weinbach. Observe the nature of the interpellation, the invocation of the subject and his/her own initiative, hence the previously cited invocation of the subject, which Althusser already correctly analyzed as the basis of the relationship of immediacy between the state and the individual; Louis Althusser, 'Ideologie und ideologische Staatsapparate' (English translation: 'Ideology and Ideological State Apparatuses'), Hamburg I977.

34 Cf. Bommes, Erarbeitung eines operationalen Konzepts zur Einschätzung von Integrationsprozessen und Integrationsmaßnahmen.

35 An integration policy for migrants, applied as an explicit programme, is at the same time twofold. As previously mentioned, it aims to achieve the integration and 
integration capacity of migrants, viewed as their orientation toward a self-reliant lifestyle. At the same time, together with an increasingly Europe-wide organised policy of migration control aimed at citizens, it symbolically communicates the following: that migration is being controlled, thus limiting avoidable competition; that allowable and unavoidable migration is being regulatorily shaped; and that migrants are not being given advantages but are instead being subjected to the same demands for adaptation as non-immigrant citizens.

36 Not least of all in the area of migration, as can be observed from the example of illegal migration; cf. also Berndt Ostendorf, 'Einwanderungsland USA? Zwischen NAFTA und Terrorismus', in: Rat für Migration (pub.), Politische Essays zu Migration und Integration, I/2007, Osnabrück 2007, p. Io, http://www.rat-fuer-migration.de.

37 Cf. Vicki Eaton Baier, James G. March \& Harald Saetren, 'Implementierung und Ungewissheit', in: James G. March (ed.), Entscheidung und Organisation. Kritische und konstruktive Beiträge, Entwicklungen und Perspektiven, Wiesbaden I990, pp. I7II84.

38 Michael D. Cohen, James G. March \& Johan P. Olsen, 'Ein Papierkorb-Modell für organisatorisches Wahlverhalten', in: ibid., pp. 329-372.

39 Moreover, the organisational salience of such an integration policy is shown by the fact that offices and departments compete for the right to compile such reports and for the staffing and financial resources associated with them.

40 Contingency-coping formulas accent the positive side and the unquestionable usefulness of what has been set in motion in social terms. For example, education in the education system, although the education system dismisses huge numbers of 'uneducated people' with only limited job opportunities after education; or health in the medical system, although anyone who enters hospital knows that they are exposed to risks of potentially irreversible injury. Social work also handles such issues not least with regard to migrants when it deals with the question of whether help helps or whether it instead reproduces neediness. And integration policy stresses integration when, for example, programmes for migrants in the labour market are set up - which then, however, often prove themselves empirically to be effective barriers to inclusion in Europe; cf. Muus, 'Migration and Labour Markets'.

4I Such catastrophes are neither new to modern society nor in many respects are they migrant-specific. Migrants are significantly more affected by this because of their lower class position, but violent male adolescents, harassed women and fundamentalism (to the extent that one also subsumes under this heading right-wing extremist attitudes) are hardly a monopoly of migrants - without the reference to functional similarities having brought into question the specific differences between these groups.

42 The relevant texts can all be found on the Internet page of the (German) federal government under the key term 'National Integration Plan'.

43 Among these solutions, however, there have until now been no proposals aimed at institutional, structural changes in education and occupational training, for example, the abolishment of the three-tiered school system or a legal guarantee of occupational training. By this it is revealed, among other things, that while migrants indeed ought to be viewed as permanent clients and migration as an altogether probable structural feature of the population, this is nevertheless not seen as sufficient grounds for altering the historically established structures in any far-reaching way. Precisely therein lies the provocative aspect of the views of OECD representative Schleicher, who routinely takes the opportunity to argue in favour of such farreaching reforms of the education system. 
44 The traditional reservation lay in alien status as the basis of the 'arbitrary proviso' of the nation state (cf. Knuth Dohse, Ausländische Arbeiter und bürgerlicher Staat. Genese und Funktion von staatlicher Ausländerpolitik und Ausländerrecht. Vom Kaiserreich bis zur Bundesrepublik Deutschland, Königstein i.Ts. I98I). In the present day, since II September 200I, the proviso of suspected disloyality has had an unsettling effect on the respective mobilisation efforts, particularly with regard to Muslim migrants, asserting itself from the perspective of the security services up to and including the Islam summit and spreading from there to the Summit on Integration (cf. Werner Schiffauer, 'Zur Konstruktion von Sicherheitspartnerschaften', in: Migrationsreport 2008. Fakten - Analysen - Perspektiven. Ed. for the Council on Migration by Michael Bommes \& Marianne Krüger-Potratz, Frankfurt/New York 2008, pp. 205-237).

45 This option was one of the structural elements of the German welfare state that caused Esping-Andersen to add the German welfare state to the group of continental corporatist-conservative welfare states; Gøsta Esping-Andersen, The Three Worlds of Welfare Capitalism, Cambridge 1990.

46 Cf. Susanne Benzler \& Hubert Heinelt, Stadt und Arbeitslosigkeit. Örtliche Arbeitsmarktpolitik im Vergleich, Opladen I99I.

47 The costs of the integration courses, such as is provided for in the Immigration Law, as well as those of migration counselling are also now being borne by the federal government.

48 Bertelsmann Stiftung \& Federal Ministry of the Interior (pub.), Erfolgreiche Integration ist kein Zufall. It should be mentioned only in passing that in terms of mobilisation the results of the competition are presented as proof that the local communities are moving in the direction in which they should be brought. Looking at the matter more closely, it is seen that out of IO7 communities, approximately I per cent have taken part in the competition - an anything but convincing response rate, if one is to draw conclusions about tendencies in 'the' communities.

49 Regina Höbel, Melanie Kloth, Bettina Reimann \& Ulla-Kristina Schuleri-Hartje, Voneinander Lernen. Gute-Praxis-Beispiele stadträumlicher Integrationspolitik. Ergebnisse der Begleitforschung zum Verbundprojekt 'Zuwanderer in der Stadt', SchaderStiftung, Darmstadt 2006; Schader-Stiftung (pub.), Empfehlungen zur stadträumlichen Integrationspolitik, Schader-Stiftung, Darmstadt 2005; Verbund-partner 'Zuwanderer in der Stadt' (pub.), Handlungsfeld: Stadträumliche Integrations-politik. Ergebnisse des Projektes 'Zuwanderer in der Stadt', Schader-Stiftung, Darmstadt 2007.

50 Cf. also Hartmut Häußermann \& Andreas Kapphan, 'Integrationspolitik der Städte - ein Paradigmenwechsel’, in: Migrationsreport 2008, pp. I5-47 and Frank-Olaf Radtke \& Patricia Stošić, " "Sozialraum” und "Netzwerke" - Semantiken kommunaler Integrationspolitik', ibid., pp. 77-II2.

5I Thus it is stated in an internal paper on the integration policy-related setting of priorities and goal-setting of the Länder: 'The Länder are - to the extent they are affected - unanimously of the opinion that integration can only be successful in close partnership and in coordination with the local communities.' Accordingly, in the 'Aktionsplan Integration. Nordrhein-Westfalen: Land der neuen Integrationschancen' (2006) it is stressed: 'In the integration of immigrants a decisive role is assigned to local communities. In the local context it is decided whether school integration and labour market integration are successful and what form the living-together of Germans and immigrants should take.' In the guidelines 'Land and Local Communities - Working Hand in Hand for Effective Integration' (2005), published by the Ministry of Social Security of Hesse together with the Confederation of Towns and Munipalities of Hesse, the Association of Counties in Hesse and the Conference of Municipal Authorities of Hesse, it is stressed: 'In the organization of 
and setting of priorities for integration processes, a decisive role, however, is assigned to the local communities, since integration takes place largely locally. It is here that opportunities and problems become visible. It is here that immigrants' principal spheres of life are realized and here lies the basis for a peaceful coexistence of all those who participate in the community.' Interesting too in this context are the priorities being set by the Länder in the area of integration: early childhood language acquisition/primary education, school education, child and youth welfare, training, continuing education and the labour market, families and women, housing situation/social city/integration on site, prevention and safety, health, intercultural openness, reducing discrimination and improvement of the willingness to integrate on the part of the host society. In other words: here, too, tasks are brought together that - with admittedly varying intensity - had always been done.

52 Mind you: these programmes rather than the areas of the economy, training and education which they attempt to influence and whose conditions are defined primarily in functional terms, rather than being locally determined.

53 Thus the Länder also support financially equivalent efforts on the part of local communities toward the re-orientation of their integration policy, in the state of North Rhine-Westphalia, for example, 'Projects for Improving the Taking-In of New Immigrants in Communities' or 'Projects for Intercultural Cooperation'.

54 Concerning the EU and its programmes of integration, see Mary-Anne Kate \& Jan Niessen, Locating Immigrant Integration Policy Measures in the Machinery of the European Commission, Migration Policy Group, Brussels 2007. It would be worthwhile to devote a special study to the question of what role the EU plays in this context, a subject which would, however, be beyond the scope of the present study. Apparently it is not a risky thesis to view their proposals in this field on 'policy learning' in terms of 'best practice', shaped according to the soft design of the OMC (open method of coordination) as a method of opening up opportunities for growth. On a national basis in Germany, for example, by the Bertelsmann Stiftung, the Robert Bosch Stiftung, the Freudenberg Stiftung, the Hertie-Stiftung, the Jacobs Stiftung, the Vodafone Stiftung or the Schrader Stiftung. At the same time these foundations also participate in efforts from a European perspective, such as, for instance, the Robert Bosch Stiftung in the context of the EPIM (European Programme for Integration and Migration), a union of foundations in Europe for the promotion of integration at a European level. Nor can we in this context enter into the sociologically extremely interesting question of the role played by foundations and so-called think tanks in the preparation of those moments at which the time for new ideas has arrived. Cf. for example Diane Stone, 'Non-Governmental Policy Transfer. The Strategies of Independent Policy Institutes', in: Governance, 13. 2000, Heft I, pp. 45-62.

56 Cf. Häußermann \& Kapphan, 'Integrationspolitik der Städte', und Gari Pavković, 'Vom Stückwerk zur Gesamtstrategie - Verantwortungspartnerschaften in der kommunalen Integrationsarbeit', in: Migrationsreport 2008, pp. 49-75.

57 In the 'Integration is no accident' competition, it is shown that such self-evaluation and report forms are encountered above all in those communities which have to produce such reports as a stipulation because of the outside funding they receive.

58 A perspective which is occasionally hard to sustain. Divergent experiences are, however, subject to significant communicative limitations in the established 'application poetry', such that upon reading the respective applications serially (in the framework of activity in various national and European expert committees), one gains the impression that the 'muddling through' of the daily routine work of integration vanishes behind the partitions of this mobilisation semantics. In order to avoid misconceptions: this has nothing to do with cheating (but is rather the attempt to meet expectations) and is hardly a specific feature of this area, but can easily be shown - 
in a different frame of reference also for scientific and scholarly research project applications - one is tempted to say: especially in the context of policy-oriented research such as is the case, in particular, of migration research.

59 Cf. for example the Zehn Handlungsempfehlungen. Erfolgsfaktoren kommunaler Integrationspolitik of the Bertelsmann Stiftung or Reichwein \& Vogel, Integrationsarbeit - effektiv organisiert. Ein Handbuch für Kommunen.

Go From welfare associations to many private institutions involved in social work and private educational institutions to countless private local institutions: what is involved here is a quantitatively extremely important labour market.

6I Integration policy in local communities since the I970s was and has been up to the present marked by a 'patchwork', heterogeneous character. Cf. the most recent reports of the Institute for Cultural Policy, the studies on alien advisory councils and resident alien commissioners; Bommes, Interessenvertretung durch Einfluß. Ausländervertretungen in Niedersachsen; id., Ausländerbeauftragte in den Kommunen, as well as Ulla-Kristina Schuleri-Hartje, Paul v. Kodolitsch \& Jochen Schulz zur Wiesch, Ausländische Arbeitnehmer und ihre Familien (Parts I-5), Deutsches Institut für Urbanistik, Berlin 1982-1989. With this, not only is a problem indicated but it is also shown that solutions have been oriented in a context-sensitive way. These community-based, locally specifically customised integration policies were for a long time (and in many instances still are to some extent) situated alongside or subordinate to general social policy and its administrations. The same is true of promotional measures aimed at children and young people. It is precisely this that at present delegitimises them - in some cases quite independently of the question concerning their practical viability - given that it is a matter of mobilising local communities in favour of total inclusion, that is, the visible, publicly represented treatment of migrants as a normal clientele.

62 Cf. the homepage of the KGSt: http://www.kgst.de.

63 On the detailed reasons for this, cf. Bommes, Erarbeitung eines operationalen Konzepts zur Einschätzung von Integrationsprozessen und Integrationsmaßnahmen.

64 Cf. KGSt, 'Management Kommunaler Integrationspolitik', Bericht Nr. 7/2005, Cologne, and KGSt, 'Integrationsmonitoring', Materialien 2/2006, Cologne, http:// www.kgst.de.

65 Cf. Michael Bommes, 'Einleitung: Migrations- und Integrationspolitik in Deutschland zwischen institutioneller Anpassung und Abwehr', in: id., Werner Schiffauer (ed.), Migrationsreport 2006. Fakten - Analysen - Perspektiven, Frankfurt am Main/New York 2006, pp. 9-29.

66 See also Christian Imdorf, 'Migrantenjugendliche in der betrieblichen Ausbildungsplatzvergabe - auch ein Problem für Kommunen', in: Migrationsreport 2008, pp. II3I58.

67 Cf. Nils Brunsson, The Organization of Hypocrisy. Talk, Decisions and Action in Organizations, Chichester 1989: organizations in maintaining daily business keep processes of talking about - that is, discussing themselves and their environment separate from decisions in which they communicate the premises of their daily operations as well as their actions - or rather they link the two only loosely.

68 Michael Bommes, 'Einleitung: Kommunen als Moderatoren sozialer Integration', in: id \& Holger Kolb (ed.), Integrationslotsen für Stadt und Landkreis Osnabrück. Grundlagen, Evaluationen und Perspektiven eines kommunalen Modellprojekts (IMISBeiträge 28), Osnabrück 2006, pp. II-24.

69 Häußermann \& Kapphan, 'Integrationspolitik der Städte'; Pavković, 'Vom Stückwerk zur Gesamtstrategie'. 



\title{
7 Illegal migration in modern society
}

\author{
Consequences and problems of national \\ European migration policies
}

First published in 2006 by VS-Verlag as the chapter 'Illegale Migration in der modernen Gesellschaft: Resultat und Problem der Migrationspolitik europäischer Nationalstaaten' (pages 95-116) in Illegalität: Grenzen und Möglichkeiten der Migrationspolitik, edited by Michael Bommes and Jörg Alt

Translated into English for this book by Anja Löbert

\section{I}

Discussions about the structures, causes and consequences of illegal migration or about the circumstances of illegal migrants begin in many cases, and not without good reason, by establishing what the term 'illegal migration' is supposed to signify. Here the talk of 'illegal migration' is repeatedly seen as the terminological stabilisation of a misjudgement: on the one hand, because most of those who live in Europe illegally, i.e. without a residence permit, are not 'illegal migrants' in the sense of having illegally crossed the external borders of Europe or national borders; on the other hand, because illegality as such is not, strictly speaking, based on a criminal offence but in the first instance on an offence in terms of residency law or employment law - even if it is often seamlessly connected with other infringements. Here this term is taken as a starting point, despite its ambiguity in public discourse, and the choice is made to retain the facts indicated by the term instead of trying, in the name of 'political correctness', to semantically correct defensive positions which are assumed to be closely linked with the taboo forms of description. After all, discarding this term means obscuring the important social fact which it indicates: illegal migration is always also connected to the attempt to conceal one's actions from the eyes of the law. The consequence for those affected is that they rob themselves of the legally mediated capacity for conflict and consequently find themselves exposed in differing degrees to the risk of social extortion.

Against this background it is hardly surprising that legal experts not only disagree on what legal residence means and where this ends, but they offer 
even less information on what exactly is meant by the social fact of 'illegal migration'. From the point of view of migration research, it makes sense to start from the other end and with the in-house tools of migration research, as it were, i.e. to begin with the fact of migration and then to ask what the special features of illegal migration are.

When migration becomes a matter for public discussion, what is meant is international migration. Such migrations are mainly motivated by individuals' attempts to take up opportunities to participate in labour markets, in the educational system, in families or other social contexts. So the primary concern here is not law or politics. Migrants fulfil an expectation of social mobility which is institutionalised in modern society, the expectation that they will go wherever the significant social resources for independent living can be accessed. The specificity of illegal migration only becomes visible in the light of this background: each international migration is an attempt to achieve a lifestyle; these attempts are not problematic, per se, for the social structures which are the primary motivation for migration, such as labour markets, educational institutions or families, ${ }^{1}$ but - as in all migrations crossing state borders - politics and the law intervene in these migrations in various ways.

The basis for this is the form of organisation of politics in modern society, the nation state. Political and legal interventions in international migration do not occur by historic chance and transitorily, but are the expression of a structural problem of the modern world society. On the one hand - because of the constitution of labour markets, the education system, the mass media, the institutionalisation of the nuclear family (to mention only the most important contexts) - this world society constantly generates motives for international migrations; but, on the other hand, it then restricts these migrations, because of the specific constitution of the political system, its segmented division into nation-states (Stichweh 1998).

This is generally applicable, and so far has little to do with illegal migration in particular, but does offer a perspective on it. International migrations call into question the division of the world population into state populations, and states regulate their relationship to these migrations through the intermediary of the two constitutive dimensions which define their relationship to their own state populations: the relationship of loyalty, which, in the name of maintaining political sovereignty, demands compliance with state decisions from citizens and all other persons present in the territory; the relationship of service which obliges the state in return to provide services of legal, political and social security, such as are contained in the concept of the welfare state (Marshall 1992). It is possible to show that nearly all political forms of regulation of international migration are structured by aspects which pertain to these two dimensions, i.e. questions of loyalty and welfare-state service provision (Bommes 1999). At present, this can easily be illustrated by the fact that, on the one hand, migration and terrorism are 
repeatedly treated as closely linked in public discourse, pointing to the issue of loyalty, and that, on the other hand, there have been repeated discussions in recent years in all European states about whether immigration contributes to the productivity of welfare states or reduces it (Bade \& Bommes 2004).

And yet attempts to regulate international migration in European welfare states are at the same time part of a redefinition of the service relationship which these states are undertaking in their relationship with their national populations, in the context of a restructuring of their welfare-state security systems. Beyond any precise definition of its magnitude, illegal migration has gained importance in the European context (and elsewhere), with a sort of double political movement having been noticeable since the early 1990s:

- On the one hand, a comprehensive attempt to clarify the historical and future conditions of the social integration of the migrant populations who are present in these countries with a long-term and fixed residence status (Michalowski 2006). Here there is a striking convergence between the opening up of the conditions for naturalisation and the increased focus on the issue of integration under the maxim 'supporting and requiring' (fördern und fordern) in the activating welfare state (Groh \& Weinbach 2005). This does not indicate that these states are targeting their migrant populations especially, but that they are tailoring the general redefinition of the service relationship between the welfare state and its potential beneficiaries in a migrant-specific way (Bommes 2003).

- On the other hand, and corresponding to this, considerable efforts on the part of these states in selecting which migrants they want to have in future, and which they do not want, and in enforcing these decisions. This implies, on the one hand, an opening-up to those migrants who are considered potentially productive (especially highly qualified persons, entrepreneurs, students) and, on the other hand, restrictions on opportunities to immigrate on humanitarian grounds, on family reunification and marriage migration, as well as the upgrading of control capabilities in these states and the EU for the purpose of prevention of and defence against unwanted migration.

- Social integration and control of migration thus constitute the two core building blocks of current European and in this context also German migration and integration policy. ${ }^{2}$

Illegal migration has gained importance in this constellation in Europe, both empirically and with regard to the political attention it attracts. It forms the flipside of this structural context of European migration policy. In the first instance, like other forms of migration, it connects directly and primarily to social opportunities, such as are to be found in labour markets, 
in education and health systems, and in families. From the migrants' point of view, illegality and its implications for the social forms of lifestyle are an unavoidable side-effect, given the lack of alternatives for legal access, which they (must) put up with if they are to seize these opportunities, despite legal prohibition and political attempts at control and at enforcing this prohibition. ${ }^{3}$ One component of their lifestyle is therefore always the attempt to keep this lifestyle from coming to the attention of the law and politics - with many and varied implications for their social capacity for conflict and for their access to services such as health or education, insofar as these are provided by the state and/or closely linked with the state's apparatus for registration and control.

For illegal migrants, however, such opportunities to participate arise in labour markets, families and elsewhere, and gain greater permanency because there is a receptive context for them, one which is in part politically and legally constituted by the same welfare states which seek to control and prevent these migrations. This is not meant only in the trivial sense that everything which is illegal about illegal immigration is only illegal because there are corresponding laws which limit or prohibit residence or work, but more particularly in the sense that motives arise in labour markets, in private households, in housing markets or in welfare organisations themselves to disregard such limitations or to use them as boundary conditions for establishing employment relations and tenancies, for starting families, providing services or setting up aid organisations which would scarcely come about otherwise. Two examples: services in private households, such as housework, care services, home renovations and repairs are only in demand because they are offered and very reliably carried out by migrants at prices which are affordable and socially acceptable for private households. ${ }^{4}$ And in the area of building, which is considered particularly susceptible to undeclared labour supplied by illegal migrants, it was, not least, the Europe-wide restructuring of the whole sector in the wake of the establishment of the freedom to provide services in the EU which created a context for the attraction of illegal migration and employment (Hunger 2000; Bommes, Hoesch, Hunger \& Kolb 2004).

In other words, illegal migration is the result of an interplay of societal structures which have their foundations in countries of origin, in which the migrants find no opportunities to fulfil their aspirations, in processes of globalisation, and not least in the countries of immigration themselves. The latter are, in a general sense, richer in opportunities, but at the same time offer only very selective opportunities for immigration, in order to uphold not only the general barrier of inequality between states, but also the relative welfare-state privileging of their citizens (or the legally resident population). But the flipside of this is that they are at the same time producing, in parallel, a high level of receptiveness for illegal migrants, and are thus creating the opportunities which are connected to illegal migration - 
otherwise it would be difficult to understand why so many people seize this opportunity. Seen in this light, illegality denotes in a sense the 'locational advantage' of these migrants, since their availability makes it possible to circumvent taxes and social contributions and establish employment relations or access services, most of which would otherwise not come about at all (Schneider \& Enste 2000; Enste \& Schneider 2006).

What sets illegal migration apart from other forms of migration, then, is not the focus on establishing employment relations, occupying housing space, living with one's family or utilising health services, but a constitutive element of its social structure, the fact that these attempts conflict in various ways with legal regulations which limit or exclude the opportunities for migrants to enter into such relations, and in this respect cause illegality. These attempts are thus subject to limitations based on forms of control and law enforcement which differ from state to state.

This, however, points to illegal migration as a paradox of a society which for structural reasons has not yet dispensed with controls on international migration and thus gives this problem a remarkable dynamic of escalation: illegalisation causes a specific demand for migrants which is based on the attempt to avoid socio-political and tax-related regulations - the same rules which the control of migration is supposed to uphold. It is therefore possible to assume that illegal migration is a 'productive societal problem' which has a range of structural effects on the various areas of society and which produces numerous solutions which contribute to the reproduction of the problem.

If one assumes, following this argument, that illegal migration denotes a self-generated problem of modern society which has its roots particularly in the state-based constitution of its political system, then this explains at the same time why public political discussion of this problem mainly take place in a field of tension determined roughly by two opposite poles. On the one hand, there is the insistence that current laws should be enforced, and the attendant view that illegal migration is the result of inadequately equipped state mechanisms of knowledge and control. The consequence of this is political support for expanding these mechanisms. On the other hand, attention is drawn in particular to those consequences of illegal migration and employment which pertain to the social circumstances of illegal migrants and their families, in particular problems of the withholding of wages and social vulnerability to extortion, the inadequate supply of housing and health services, or the limited access of their children to schooling and training. Both positions articulate the paradox sketched above in an illuminating way: politically, states can certainly accommodate - depending on the history of their self-establishment and organisational composition - each in its own way, the non-enforceability of a portion of their political decisions and of the relevant legislation. Nonetheless, this is an even stronger indication of a notorious structural problem, if it is 
simultaneously the result of efforts to solve it. On the other hand, the illegalisation of migration results in social circumstances which, when publicly discussed, confront society in the European welfare states with problematic consequences whose existence is considered barely tolerable in the light of institutionalised rights such as access to health care or the universal right of children to schooling and training - and which are nonetheless in the first instance the result of illegal migrants' self-exclusion from the law. They do not arise from any neglect or withholding of rights on the part of welfare states, and yet there is an expectation that these states should intervene socio-politically, and desist from enforcing laws and policies. We will return to this in section III when considering the possibilities and limitations of states' powers of control with regard to illegal migration.

\section{II}

It can be assumed that illegal migration leads to specific manifestations in the socio-structural contexts in which they feature, i.e. in labour and housing markets, in state and non-state organisations for the production of knowledge and control, in the education and training system or in the health system. Such structural effects of illegal migration on various areas of society are actually very rarely discussed systematically, except where they can be used in support of the positions taken up in the public debate outlined above, be it the criminality of 'smugglers' and 'people traffickers', the unscrupulousness of employers or landlords in their dealings with illegal immigrants, or the inflexibility of government agencies in dealing with the difficult circumstances of illegal migrants. This striking fact seems to arise from the apparent fascination exerted by the normative snares of the paradox of illegal migration. If one assumes, however, that illegal migration is a continuously abnormalised normal feature of all major immigration regions, and will remain so into the foreseeable future, then it is surprising how little attention has been paid to asking, in very general terms, what social structures arise from migration and what significance they have for society, or what can be learnt about society from them. ${ }^{5}$

One observation to be made in this respect is that relatively little is known about illegal migration and its effects in Germany, and that no intensive research has been done on this (AKI 2004). On the other hand, however, there are a number of indications in existing German and international research that it is worthwhile asking questions in a way that allows illegal migration to be seen not just as a matter entailing mainly political and normative problems, but as one which also offers insight into society.

And yet, for an adequate understanding of illegal migration and its consequences, no other approach is required than the normal methods of 
migration research. Like any migration, illegal migration can be sociostructurally significant in the following systematic respects:

1. Like all migrations, illegal migration affects the functionally differentiated subsections of society, each in specific ways. Illegal migration and the social inclusion of these migrants (i.e. their integration) do not denote a compact matter, but different things in each context. The inclusion of illegal migrants has different effects on the structures of the labour market, the housing market, the health system, the education system, social work, politics and the law as well as, finally, families. In order to understand this in detail, it is necessary to look at the options and barriers which enable or block the inclusion of illegal migrants in these various areas, and at the prerequisites which the illegal migrants bring themselves, i.e. their so-called 'human capital endowment'. The central question is then that of the structural consequences which illegal migration and the multiple inclusion of migrants have for these areas of society.

2. Functionally differentiated society is characterised by structured social relations of distribution and inequality. The presence and employment of illegal migrants also have effects on the social relations of distribution and inequality. The manner in which this occurs is not yet fully understood.

3. The conditions in which illegal migrants live vary, depending on their varying opportunities for access to social systems and the access to social resources mediated through them.

4. Illegal migration, both the conditions of the actual migration and the politically and legally criminalised opportunities for access to work, housing, education, health and so on, gives rise to specific forms of migration and settlement and to related structural developments, social networks and organisations which evolve on the basis of the specific problem situations associated with illegality, such as transport, papers, informal recruitment, avoidance of compulsory registration when renting accommodation, or the provision of health services.

When considering illegal migration in this light, it makes sense to be more cautious in grappling with normative questions, at least until there has been sufficient investigation into the relevant context and adequate knowledge is available to form an opinion. Depending on what this knowledge turns out to be, however, it may reveal not only that the facts are different to what was expected, but that the options for normative intervention prove extremely limited or non-existent. The following examples illustrate this.

Studies on illegal migration networks and trafficking from Ecuador and China show that the emergence of such networks and smuggling organisations picks up on structures which have a long history, sometimes going back several hundred years (Kyle \& Koslowsko 2001). This is also shown 
by the immigration and by the forms of trade and social forms of Senegalese street traders in France, Italy and Spain. ${ }^{6}$ Such studies are instructive for Germany since they draw attention to the historical prerequisites which explain the dynamics and the exact process of illegal immigration. As yet, however, illegal immigration from Eastern Europe and Asia has hardly been studied from this perspective. ${ }^{7}$

Studies on the circumstances of illegal migrants in Germany have repeatedly drawn attention to their low and irregular incomes and their risk of impoverishment (Alt 1999, 2003; Anderson 2003). Studies in the US, however, show that the below-average incomes of illegal migrants cannot be ascribed one-dimensionally to the fact of their illegality and the resulting limited options for action or chances of discrimination, but that they are also related to their human capital endowment, the length of their stay, language skills and so on. It is surely no coincidence that a country which has a long experience of illegal immigration is able to matter-of-factly use insights and methods from general migration research for the comparison. Such studies then show that the status of illegality also has a substantial causal role in the - on average - lower incomes of illegal migrants, though they are unable to explain exactly how this status affects income. A number of questions still remain open here.

Political discussions of illegal migration and employment repeatedly evoke the assumption that it is connected with severe detriment to the economy. This is primarily based on the loss of tax income and social security contributions. This is contradicted, on the one hand, by the fact that the economic transactions in the shadow economy would in large part not be carried out at all if valid tax and social-law conditions were to be observed (Schneider \& Klinglmair 2004: 29; Entorf \& Moebert 2004; Jahn $\&$ Straubhaar 1998). Furthermore, the economic processes in the shadow economy and therefore the employment of illegal migrants apparently generate overall growth effects, which seem, however, to be simultaneously associated with profits for certain groups of market participants and with losses for others, i.e. with an overall effect of increasing social inequality (Zimmermann 1998; Del Boca \& Venturini 2003).

In this context little is known about a number of other important connections which are significant for an assessment of the social structures resulting from illegality and for the related living conditions. This concerns questions about how illegal migrants are recruited as labour, how 'contracts' and 'rates of pay' come about in this context, how social trust can be built up under conditions of limited utilisation of law and politics (i.e. in the absence of 'trust in the system') and how compliance with such contracts can be enforced if need be (e.g. through 'thug squads' as a sort of functional equivalent of the police). What consequences do illegal employment relations have for quality and safety standards? These questions are aimed at systematically clarifying how the social relations arising from 
illegality are structurally shaped by the limited capacity for conflict, in the absence of recourse to the law. It is also striking that, in the area of illegal employment, the economy does not follow theoretical models, as it were, but works empirically in conditions of legal and political 'disembedding'.

Depending on the legal and political forms of regulation, illegal migrants in countries such as the US, the UK and Italy seem to find employment in many more areas than they do in Germany, and the mode of illegal migration (permanent vs. circular) also seems to be connected with this (Cyrus, Düvell \& Vogel 2004; Stobbe 2004). In Germany, evidently through the coupling of residential and employment law, frequent checks, and the prioritisation of control in the name of 'internal security', illegal migrants have been pushed aside into particular areas, which probably also has the overall result that the number of illegal migrants can be kept lower. ${ }^{8}$ In an international comparative perspective, however, it is also evident that Germany pays a high price for the strict illegalisation of employment since the lamented loss of taxes and social contributions is also the consequence of a strict and cost-intensive policy of control. In Anglo-Saxon countries, the enforcement of tax and social contribution liability can be strictly separated, formally and organisationally, from control problems related to residence law, but the German rule of law tradition does not allow this. ${ }^{9}$

Anyone dealing with illegal migration and its social consequences inevitably comes to the question of the legal boundary conditions of illegal migration and employment and the forms of organisation of state control. There are constitutive boundary conditions for social structural developments in all other areas. At the same time, however, an astonishing limitation in the discussion of politics, state and law is to be found here, since they are considered only as regulators of the remaining societal relations, but not as cases which are themselves empirically illuminating, which form specific social structures in the wake of illegal migration, by helping to produce them (as shown above) and in turn reacting to them. Law and politics are not themselves made the object of analysis, but in a sense incite direct participation, with a normatively regulative intention. Thus, empirically, surprisingly little is known about how political and legal organisations react to illegal migration, the related attempts at evasion and selfexclusion, and what problems of knowledge production, control, legal findings and law enforcement they are engaging with. There is no lack of normative positions about what the police, the aliens' authorities, the customs offices, the German border control, etc., should be doing, nor is there a lack of normative doubts about whether these authorities are coping adequately with their tasks and doing what they themselves report. But there is hardly any reliable knowledge about how such organisations function, how knowing and not-knowing are dealt with under conditions of uncertainty, and in what ways the dynamic of state organisation-formation 
corresponds to the dynamic of illegal (and legal) international migration, in a relationship of reciprocal escalation. ${ }^{10}$ As long as states and their organisations are mainly understood as the control unit of 'society' - and this also defines most analyses in legal studies and political science - they will not be understood as part of the reality of illegal migration and of its social dynamic, which needs to be thoroughly examined and understood.

\section{III}

Nation-states are an internal component of the relations of migration in modern society, and illegal migrations confront these states with problems which draw attention to the necessities, possibilities and limitations of their migration policy, which have their roots in the paradoxes explained in section I. Nation-states cannot renounce their right to control access to and residence in their territories. This right is implemented very differently in different states. In Germany it is wide-ranging and penetrates numerous areas of society. Illegal migration is the recurring, regular challenge to this right and, as shown above, is able to catch up with societal relations and in its own political manifestation.

A number of problematic social consequences are connected with illegal migration, particularly in relation to health provision, legal protection or the schooling of the children of illegal migrants - and this is neither because they exceed the states' ability to deal with these problems (at least in the case of the European welfare states), nor because these welfare states deny these services, in principle. Nonetheless, demands are made, especially by organisations with a religious or humanitarian focus, that these states should remedy these problems. These demands range from the legalisation of illegal migrants to the provision of legal protection and health care, and the inclusion of the children of illegal migrants in schools, regardless of their parents' unlawful residence.

The demand for the legalisation of illegal migrants is a reaction to the fact that many of these migrants, on the basis of their unlawful residence, enter employment, live, start families or send for their families and bring up children, and that this process increases with the length of their stay. In other words, they go through processes of social integration and build up corresponding social connections which are, on the one hand, marked by the insecurity of their illegal status and, on the other hand, subject to the threat of destruction which might ensue if they are discovered and deported. This is registered socially as a problem, since it is only the unlawfulness of their residence status which prevents them from more or less successfully leading a normal life. In the media this is shown to dramatic effect with images of aliens' authorities tearing migrant families from their precariously established normality, putting them onto planes and deporting 
them to their countries of origin, which they may have left long ago and where they will have to largely rebuild their opportunities to make social connections, if such opportunities exist at all. This is a thoroughly everyday form of documentation for the contradiction described at the beginning of this essay, that modern society generates multiple motives for migration on the basis of its social opportunities, while at the same time taking pains, politically and legally, to limit or destroy them. Against this background, the demand for legalisation of illegal migrants gains plausibility from the fact that destroying the possibility of a civilian lifestyle is seen as problematic in the light of the principle of equality in democratic constitutional states, and in the light of a universalism which assumes that work, family, education and health should be available to all individuals. This also brings into sharp focus particular universalism of statehood and citizenship (Bommes 1999), since they make equality and universalism dependent on the particular aspect of ancestry and origin - and yet at the same time the demands made for equality are addressed to them.

But even the demand for legalisation of illegal migrants takes this particularism as its basis and does not seriously question it - given the lack of an alternative to statehood as the central organisational form of politics in modern society. And this is exactly where the difficulties of this demand lie - and of all demands which try to justify the access of illegal migrants to health, legal protection and education in terms of principles and human rights. Because legalisation does not challenge the fundamental right of states to control access to and residence in state territory, on the basis of national and international law. What is demanded is, in a sense, the belated political recognition of the empirical facts of the relations of migration and their social results, not least, as we have seen, in view of the living conditions of the migrants concerned.

Legalisations are, from a systematic point of view, amendments to the law in the light of a situation in which law enforcement was or is not empirically possible - it is not or has not been possible to prevent politically unwanted immigration effectively by political means. Legalisations put an end to a situation in which something was not allowed, but in which the law could not be enforced. In principle, however, there are always two options when reality moves too far away from legal regulations: to increase efforts at law enforcement, or adapt the law itself. And both options are associated with risks: in the one case the failure of law enforcement exposes the limited sovereignty of the state, in the other case the legalisations paradoxically generate the conditions for a future re-emergence of the thing which was supposed to be eliminated - the presence of a large number of illegally resident persons in the state's territory. Legalisations generate expectations and therefore renewed motives for others to try as well. Thus, expectations develop on the part of migrants. ${ }^{11}$ Legalisation measures such as have been carried out in Italy, Spain or Greece are considered scarcely 
viable in German politics. In light of the insoluble difficulties discussed above, which are connected with legalisation and have their roots in the paradoxes of illegal migration, it seems overly hasty to ascribe this to an inability to learn. Whether states resort to legalisation measures or not can be better explained with reference to their history and their organisational capacity for enforcing law, in general. It then becomes evident, for example, that the legalisation of migrants in Italy does not mean a break with state tradition, since, for example, the legalisation of illegal building work takes place comparatively regularly there (Finotelli 2006), while such regular, generalised amnesties are more unusual in Germany. ${ }^{12}$ In the area of migration, too, legalisation does not take place in a generalised way, but in an individualised, case-by-case approach - and even this is associated with the creation of expectations.

Prospects of a legal immigration status exist not only in those countries which carry out generalised legalisation measures, but also, in a different form, in Germany. The elaborate apparatus of migration control, linked with an equally elaborate supply system - in comparative terms - drives the migrants who do not evade control altogether, for want of an alternative, into procedures in which they seek asylum or refugee status as the only accessible legal residence status. The number of asylum and refugee applications recognised is now low in all European countries. In parallel, however, the numbers of 'tolerated' foreigners (gedultete Ausländer, i.e. those with exceptional leave to remain) in Germany has risen continuously since the mid-1990s; in recent years there have always been more than 200,000 cases. There are therefore local authorities, such as a town in Westphalia, in which around 600 asylum applicants and over 2000 'tolerated persons' (Geduldete) live. ${ }^{13}$

As in the case of legalisation, this is about handling the paradoxes of illegal migration, in the form of the Duldung (temporary toleration/exceptional leave to remain). The underlying fact is an unlawful state of affairs which cannot be ended and is therefore given a secondary legal form: that of the Duldung. Here too, the state lacks sufficient enforcement capacity to carry out the administrative consequence - deportation - which arises when a migrant is found to be unlawfully resident. The systematic reason for this is the territorial limitation on the sovereignty of nation-states. In many cases they are unable to persuade other states to accept persons who are to be deported and/or to treat them in such a way that this does not pose an obstacle to their deportation. ${ }^{14}$ The result is the presence of migrants who are not actually allowed to stay, but who now need to be given a legal status, ${ }^{15}$ because their deportation cannot in fact be carried out, and this cannot be blamed on them. ${ }^{16}$ The fact that an illegal state of affairs cannot be ended is thus dealt with in a form of quasi-legalisation which is tailored to individuals with long and often hopeless careers within the asylum process, and which is then followed by the so-called Altfallregelungen 
(old case or longstayers regulations) if need be. Altfallregelungen are, however, nothing other than a form of legalisation tailored to individuals who have been through long and hopeless proceedings of this kind. The provision for imposing a time limit on the extension of Duldungen in the German Immigration Act (Zuwanderungsgesetz) valid from 1 January $2005^{17}$ is based, on the one hand, on the experience that attempting to enforce the law is empirically largely futile and that it makes more sense, both in terms of administrative costs and in terms of encouraging migrants to live independently and free of social-state subsidies, to provide them with a regular residence status. On the other hand, the vagueness of the law's phrasing leaves it up to the authorities to judge whether there is any chance of successfully enforcing the order to leave the country - and this makes it clear that such legal regulations are formulated on precarious terrain: they are concerned with the legal limitation of the enforcement of the law with regard to unlawful residence.

Like legalisation, such forms of dealing with illegal migration lead to the social build-up of expectations on the part of the migrants - it can be done. This also emerges from the case presentations by Alt $(1999,2003)$ and Anderson (2003) about illegal residents in Leipzig and Munich. The migrants whom they interviewed experience fragmented careers between legality and illegality, connected to the hope of eventually being able to shift from a weak status such as that of Duldung to a legal status.

Both legalisations and Duldungen are interesting political-legal forms of dealing with illegal migration: they are reflexive political forms of adapting to and perpetuating an insoluble problem, accompanied by a political commentary which nonetheless absolutely insists on the validity of existing laws and their effective enforcement. In the light of the empirical relations of migration, there are displays of advocacy for illegal migrants and their rights, and demands for legalisation and longstayer rulings: the eternal perpetuation of the illegality of migrants with all the social problems which it entails is seen as problematic. Such demands are by no means futile, and have recurring success. But since they martial the forces of empiricism, they are always confronted with the difficulty that - and this can scarcely be denied - legalisations of various kinds contribute to the perpetuation of the problem which they are meant to help solve.

Against this background, it is striking that, in the same context, those advocating access for illegal migrants to social rights such as legal protection, health care and schooling not only use humanitarian arguments, but primarily argue on the basis of principles, with reference to human rights (Bielefeldt 2006; Rausch 2006). This is meant - by way of normatively final criteria which cannot be called into question by the European welfare states on the basis of their current laws - to immunise these demands against empirical objections, for example, that the opening up of access to such rights might create new incentives for illegal migration. This is, 
however, not wholly convincing, since the problem is not, under closer inspection, that legal protection, health care or schooling for their children are withheld from illegal migrants in European welfare states, in principle. On the contrary, these are always open to them, and they in some cases exclude themselves from such provision because they associate the exercise of rights, the acceptance of health care services, and sending their children to school with the fear that their unlawful residence status will be noticed by the administration and that the foundations for their continued residence and livelihood in the country of immigration will be taken away from them. This is understandable enough, but can hardly justify a fundamental demand that the state should limit its right to knowledge and control so illegal migrants can claim legal protection, health services, or schooling for their children - since this would presuppose that illegal migrants had some sort of right to disregard the law.

This does not exclude the possibility that it might make sense for states to make such benefits accessible in some form to illegal migrants too, by renouncing their right to surveillance and law enforcement for pragmatic reasons. Arguments for this, however, will again be constructed more along empirical/functional lines, and less in terms of normative principles. As in the case of legalisations and Duldungen, the question of the provision of benefits such as legal protection, health services and education for illegal migrants is also about coping with the consequences of the fundamental fact that disregard for the law occurs regularly and cannot be effectively prevented. On the one hand, the claim to law enforcement cannot be limited, in principle, let alone given up altogether, even if it cannot empirically be implemented. On the other hand the resulting social consequences cannot be politically and legally ignored; instead, they require reflexive forms of handling, such as legalisations and Duldungen, as forms of repair for the non-enforceability of law. Similarly, it can be shown that it can make sense for states to provide legal protection, health care or schooling for illegal residents by renouncing their own right to control, in light of the consequences of not taking this into consideration.

Guaranteeing legal protection without insisting on the clarification of a person's residence status can for example be advisable not just for reasons of justice or the prevention of fraud, but also to prevent the formation and growth of islands characterised by social relations of dependence and power. The aim would then be to prevent illegal migration, which does not primarily signify criminal behaviour on the part of individuals in a narrower sense, ${ }^{18}$ from giving rise to secondary areas in which central aspects of life such as working, income and housing conditions are exempt from the law.

Giving illegal migrants access to health care without insisting on the state's right to control and record, as established particularly in German, is not only seen as a means of preventing the human misery which results 
from the avoided or belated utilisation of health services. It is also a duty of public health care, since the non-utilisation of health services also constitutes a danger to public health, insofar as it can contribute to the spread of contagious diseases. The establishment of relevant services such as the Malteser health service in Berlin shows that corresponding provisions are possible and that corresponding legislative adjustments for these kinds of pragmatic reasons are now finding political resonance (cf. Bommes \& Alt 2006: 193-210).

Finally, it is also in the interest of states themselves to effectively guarantee schooling for children of illegal families; schooling of the children does not in itself stand in the way of a return or deportation of illegal migrants, should this be necessary, but gives the children qualifications and skills in the meantime, which will also stand them in good stead if this does happen. But as long as the state cannot effectively prevent illegal migration and the settlement of illegal migrants, keeping children away from school because of the fear of discovery will contribute to the perpetuation of their social marginalisation in the future, and will foreseeably increase the resulting social costs.

By looking at other countries we can learn that it is possible to find arrangements which make it possible to deal with the above-mentioned problems resulting from illegal migration. Such an arrangement can, as shown, hardly be demanded as a matter of principle, for reasons of human rights. But since illegal migrations represent a significant case of unsuccessful law enforcement, for which states must hold themselves accountable, it is required of them that they deal with the resulting problems and find pragmatic forms which allow this without at the same time rewarding lawbreaking and the undermining of political sovereignty, or creating incentives for this. All such arrangements are concerned with the weighing-up of various highly valued, but conflicting benefits: the validity of the law and the state's capacity for law enforcement, on the one hand, and on the other hand, the potential exclusion of a large number of people from benefits such as health, legal protection and schooling, resulting in potentially high costs for individuals and society.

Finally, it should be borne in mind that the paradoxes of illegal migration appear to allow only solutions which are always part of the reproduction of the problem. They do not allow any fundamental solutions, be it law and order solutions, which take a tough legalistic stance, insisting on valid law and its enforcement, and yet cannot ignore the fact that they are confronted with problems which emerge on the flipside of state migration policy itself; or be it solutions based normatively on human rights, which have trouble coping with the fact that the social problems resulting from illegal migration are based on the self-exclusion of migrants from the law. But if these are paradoxes which have their roots in the structural principles of modern society and the resulting contradiction, i.e. the simultaneous 
production and limitation of motives for migration, then it is unlikely that generally valid solutions can be found. But is this a deficiency? Pragmatic arrangements as a productive and problem-oriented way of dealing with the consequences of insoluble contradictions expect error and failure and take them as an incentive to develop practicable corrections. Principlebased solutions have, by virtue of their construction, the charm of the imperative - and those who believe in them are generally determined to see them through, even if they are incompatible with reality.

\section{Notes}

I This can be seen in the case of internal migration, which, socially, is in many cases not registered as migration at all.

2 This is also clear from the structure of the 2004 annual report of the Zuwanderungsrat (German Immigration Council).

3 They are dealing in a sense with the paradox which imposes mobility on all individuals in modern society: to seek out and take up their social opportunities for participation in societal function systems where they are to be found - only to regulate and limit these attempts in political terms at state borders. This paradox also finds its expression in the fact that there is an internationally recognised right to emigrate, but no corresponding right to immigrate.

4 This implies several aspects: services of this kind often do not have to be provided by Germans or other persons with an equal socio-legal status, since they can still resort to state wage-replacement benefits (even if these have now been reduced) which at the same time make it risky for them to take on such employment illicitly. Nor should one underestimate the fact that illegal migrants bring with them a great willingness to work, in contrast to which locals offering comparable services have often experienced downward social mobility and deprivation, making it doubtful that they will be socially competitive compared to the now tried and tested illegal migrants even if these locals are put under even more pressure to accept low-paid work.

5 Cf. (but arguing in a different frame of reference) Cyrus 2004.

6 In an ongoing study on the Senegalese Murids, Sophia Gaitanidou is able to show that the forms of migration and settlement of these traders between, in particular, Southern Europe and Senegal cannot be understood without the emergence of this sect in the Igth century and its high adaptability to changing political and economic structures. Sophia Gaitanidou, 'Transnationale Migration: Die Muriden in Europa', Diss. University of Osnabrück 2006.

7 The significance of historically based constellations of immigration and settlement dynamics has also been pointed out in a general way by Alt (2005).

8 It is virtually impossible to obtain reliable information on the exact number of illegal migrants in various countries (Jandl 2003). On the one hand, this is in the nature of things but, on the other hand, it also has to do with a continuing lack of sophisticated research methods in Germany (AKI 2004).

9 In the German rule of law tradition every act of the state administration is based on legislation, and must be able to be referred back to such a basis. A consequence of this is the reconstructability of every decision in state organizations in terms of the lawfulness of state (administrative) action. This lawfulness systematically (not pragmatically, see section III) excludes the possibility that, in a state conceived as a 
single entity, its sub-organs (such as schools, social welfare offices, employment offices) might be able to disregard what is considered right and wrong in its other sections.

IO There are hints of this in some work by Cyrus \& Vogel (2002), but in the end their analysis of the control practice of employment offices is primarily focused on normative measures (of discrimination). See also the work of Scheffer (200I) on the asylum procedure.

II Empirically, this explains why fears that migrants who enter Europe via the Mediterranean might make their way to Germany are largely unfounded. As a result of the regular legalisation measures which have taken place in Italy, migrants neither enter the asylum process there nor set out for Germany, because their prospects of achieving a legal immigration status by means of a legalisation procedure are more favourable there (Bommes 2004).

I2 An example is the 'Gesetz über die strafbefreiende Erklärung' (StraBEG, 'German Act on the Declaration for the Exemption from Punishment'), valid from I January 2004 to 3I March 2005, which was meant to motivate owners of capital assets transferred overseas to declare their capital income and to pay the relevant tax in arrears without prosecution.

I3 The differences from town to town are considerable, partly due to the different administrative practices of Aliens' Authorities across the German federation.

I4 Against this background, the EU and individual member states are making increasing efforts to arrange so-called 'admission agreements' (Übernahmeabkommen) with third countries, in which these countries commit themselves to taking back not only their own citizens, but also those who have entered the EU through their states (Sinn, Kreienbrink \& Loeffelholz 2005: 54 f.).

I5 Which is at the same time a non-status: the suspension of deportation is referred to as toleration (Duldung) and therefore also the continuance of the unlawfulness of the stay, which must be accepted until further notice.

I6 This should be distinguished from the migrants' obligation to cooperate in the clarification of their case, i.e. their origin, route of entry, identity, etc. But the options for obtaining this cooperation are limited, and run from negative sanctions such as restrictions on freedom of movement and confinement in so-called reception facilities, and positive sanctions in the form of advice on return migration and financial support, as provided, for example, by the IOM, with support from the EU, in numerous countries.

I7 Just one comment: the legal form of the Duldung, the abolition of which had been demanded, in particular, by the Green Party, was retained with the argument that it allowed for 'precise management'. This could almost pass for irony, considering that Duldungen are mainly and in the first instance an expression of the fact that illegal migration cannot be managed.

I8 The police crime statistics for 2002 state: 'Nine out of ten non-German suspects who were residing in Germany illegally were registered as suspects because of infringements of the Aliens' and Asylum Proceedings Act.' (I2I) Another 7,5 per cent were registered on suspicion of forgery of documents, i.e. another matter directly connected with their illegal existence. This shows that illegal migrants are at pains to respect legislation, so as not to come to the attention of the law by committing an infringement, and thereby endanger their stay. 


\section{References}

AKI (Arbeitsstelle interkulturelle Konflikte und gesellschaftliche Integration) (2004), Migration und Illegalität in Deutschland AKI-Forschungsbilanz 1, Berlin: Wissenschaftszentrum Berlin.

Alt, J. (1999), Illegal in Deutschland. Forschungsprojekt zur Lebenssituation 'illegaler' Migranten in Leipzig. Karlsruhe: Von-Loeper-Literaturverlag.

Alt, J. (2003), Leben in der Schattenwelt. Problemkomplex illegale Migration. Karlsruhe: Von-Loeper-Literaturverlag.

Anderson, Ph. (2003), 'Dass Sie uns nicht vergessen...' Menschen in der Illegalität in München. Eine empirische Studie im Auftrag der Landeshauptstadt München. Munich: Sozialreferat.

Bade, K.J. \& M. Bommes (2004), 'Einleitung: Integrationspotentiale in modernen europäischen Wohlfahrtsstaaten', in Bade, Bommes and Münz (ed.), Migrationsreport. Frankfurt am Main/New York: Campus, pp. 11-42.

Bade, K.J., M. Bommes \& R. Münz (eds) (2004), Migrationsreport 2004. Fakten - Analysen - Perspektiven. Frankfurt am Main and New York: Campus.

Bielefeldt, H. (2006), 'Menschenrechte ,irregulärer' Migrantinnen und Migranten', in Michael Bommes \& Jörg Alt (eds), Illegalität: Grenzen und Möglichkeiten der Migrationspolitik. Wiesbaden: VS Verlag für Sozialwissenschaften, pp. 81-93.

Bommes, M. (1999), Migration und nationaler Wohlfahrtsstaat. Ein differenzierungstheoretischer Entwurf. Wiesbaden: Westdeutscher Verlag.

Bommes, M. (2003), 'The Shrinking Inclusive Capacity of the National Welfare State: International Migration and the Deregulation of Identity Formation', in Grete Brochmann (ed.), The Multicultural Challenge (Comparative Social Research 22). Oslo: Elsevier, pp. 43-67.

Bommes, M. \& Jörg Alt (eds) (2006), Illegalität: Grenzen und Möglichkeiten der Migrationspolitik. Wiesbaden: VS Verlag für Sozialwissenschaften, pp. 35-59.

Bommes, M., K. Hoesch, H. Kolb \& U. Hunger (eds) (2004), 'Organisational Recruitment and Patterns of Migration. Interdependencies in an Integrating Europe' (IMIS-Beiträge 25), Osnabrück: Universität Osnabrück.

Cyrus, N. (2004), 'Aufenthaltsrechtliche Illegalität in Deutschland: Sozialstrukturbildung Wechselwirkungen - Politische Optionen'. Bericht für den Sachverständigenrat für Zuwanderung und Integration. Berlin: http://www.bamf.de/template/zuwanderungsrat/expertisen/expertise_cyrus.pdf

Cyrus, N. \& D. Vogel (2002), 'Ausländerdiskriminierung durch Außenkontrollen im Arbeitsmarkt? Fallstudienbefunde - Herausforderungen - Gestaltungsoptionen', Mitteil-ungen aus der Arbeitsmarkt- und Berufsforschung vol. 35: pp. 254-270.

Cyrus, N., F. Düvell \& D. Vogel (2004), 'Illegale Zuwanderung in Deutschland und Großbritannien: Ein Vergleich', IMIS-Beiträge 24, University of Osnabrück, pp. 45-74.

Del Boca, D. \& A. Venturini (2003), Italian Migration. IZA Discussion Paper 938. Bonn: Institute for the Study of Labor.

Enste, D. \& F. Schneider (2006), 'Schattenwirtschaft und irreguläre Beschäftigung: Irrtümer, Zusammenhänge und Lösungen', in Michael Bommes \& Jörg Alt (eds), Illegalität: Grenzen und Möglichkeiten der Migrationspolitik. Wiesbaden: VS Verlag für Sozialwissenschaften, pp. 35-59.

Entorf, H. \& J. Moebert (2004), 'The Demand for Illegal Migration and Market Outcomes', Intereconomics vol. 39 (1): pp. 7-1.

Hunger, U. (2000), Der 'rheinische Kapitalismus' in der Defensive. Eine komparative PolicyAnalyse zum Paradigmenwechsel in den Arbeitsmarktbeziehungen am Beispiel der Bauwirtschaft. Baden-Baden: Nomos. 
Jahn, A. \& Th. Straubhaar (1998), 'A Survey on the Economics of Illergal Migration', South European Society \& Politics vol 3 (3): pp. 16-42.

Jandl, M. (2003), Estimates of Illegal Migration in Europe. Vienna: International Centre for Migration Policy Development (ICMPD).

Kyle, D. \& R. Koslowski (eds) (2001), Global Human Smuggling: Comparative Perspectives. Baltimore, London: Johns Hopkins University Press.

Marshall, T.H. (1992), Bürgerrechte und soziale Klassen: Zur Soziologie des Wohlfahrtsstaates. Frankfurt am Main: Campus.

Schneider, F. \& D. Enste (2000), Schattenwirtschaft und Schwarzarbeit. Umfang, Ursachen, Wirkungen und wirtschaftspolitische Empfehlungen. Munich and Vienna: R. Oldenbourg.

Schneider, F. \& R. Klinglmair (2004), Shadow Economies around the World: What Do We Know? IZA Discussion Paper 1043. Bonn: Institute for the Study of Labor.

Stichweh, R. (1998), 'Migration, nationale Wohlfahrtsstaaten und die Entstehung der Weltgesellschaft', in Bommes \& Halfmann (ed.), Migration in nationalen Wohlfahrtsstaaten. Osnabrück: Universitätsverlag Rasch, pp. 49-61.

Stobbe, H. (2004), Undokumentierte Migration in Deutschland und den vereinigten Staaten. Interne Migrationskontrollen und die Handlungsspeilräume von Sans Papiers. Göttingen: Universitätsverlag.

Zimmermann, K.F. (1998), Immigration und Arbeitsmarkt. Eine ökonomische Perspektive. IZA Discussion Paper 7. Bonn: Institute for the Study of Labor. 



\section{General and specific characteristics of networks (with Veronika Tacke)}

First published in 2006 by VS-Verlag as the chapter 'Das Allgemeine und das Besondere des Netzwerkes' (pages 37-62), co-authored with Veronika Tacke, in Qualitative Netzwerkanalyse: Konzepte, Methoden, Anwendungen, edited by Betina Hollstein and Florian Straus

Translation into English for this book by Teresa Gehrs

\section{Introduction}

Networks are everywhere. They operate in all areas of society. They range from local community networks, business development networks, scientific and health networks, women's networks and anti-discrimination networks to those associated with problems in society, such as trafficking and criminal drugs procurement. It is evident from such a list that two kinds of network exist. The first type has a positive connotation and is deemed in political, economic, legal and scientific terms to be a force for good. In other words, their development does not just simply occur, but is proactively regarded as a goal in itself. The second type of network has a negative association, which is why the aim is to prevent or destroy them. However, regardless of whether they are assessed as positive or negative, or whether they are scientific or trafficking networks, there is generally no question about whether they are indeed networks. Yet what do business development networks and criminal procurement networks have in common? Labelling them is of no help either; this merely conceals their considerable ambiguities. Any reference to what generally constitutes a network, and whether their characteristics can be generalised, is therefore avoided.

Furthermore, not all networks actually call themselves networks. Conversely, not every grouping that describes itself as a network falls into the definition of a network in sociological terms, at least not when one assumes that it is scientifically possible to capture the concept in greater detail and to define what can be deemed as a network, and what cannot. From a sociological perspective, a differentiation must therefore be made 
between a 'network' as a social structure within society and a 'network' as defined in everyday language by society, which is a looser interpretation. One reason for this differentiation is that the present-day shifting use of the term 'network' creates social complexity. Seemingly arbitrary social relationships are labelled as 'networks', and it has therefore become a catch-all concept: whereas in the past workgroups, roundtables or associations were established, nowadays 'networks' are created. The social sciences take some responsibility for this semantic diffusion. After all, the term 'network' has gained considerably in popularity over the past two decades in business science and business administration (Williamson 1996; Thorelli 1986; Monse 1992; Sydow \& Windeler 1994), political science (Mayntz 1993; Kenis \& Schneider 1996), law (Teubner 1992, 2000), and sociology (Powell 1990; Grabher 1993; Mahnkopf 1994; Weyer 2000).

Several reasons for conceptualising the essence of the network in greater detail from a sociological perspective have already been mentioned, the definition of which simultaneously allows for several minimum requirements. It has also been recognised that networks exist in all kinds of social contexts. For this reason, a sociologically adequate general concept of the network must be developed that is capable of describing common features of widely diverse networks. At the same time, the concept must be constructed to be sufficiently adaptable for the very different contexts in which networks exist in society. In addition, such a sociological structural concept of the network must be distinguished from social semantics, which give the concept of the network a meaning that is fit for use in both a systems setting and an economics setting. The prerequisite for this is a sociological theory that differentiates between social structure and semantics and that simultaneously focuses on their relationship with one another (Luhmann 1980; Stichweh 2000a). ${ }^{1}$

The development of such a concept of the network is inter-related with the differentiation between the construction and the portrayal of social circumstances conventional in everyday use. Not every portrayal of sociality as a network corresponds to the construction of a network structure - and not every network that emerges in society as a structure presents itself as a network in communication. Social relationships portray themselves as networks when social forms, ${ }^{2}$ objectives, values and reference problems that have a positive connotation in society can be associated with them ('women's network', 'innovation network'); by contrast, where illegitimate possibilities can be realised in a social and contextual respect, such groupings appear not to portray themselves as networks; opportunities for them being labelled in such a way by external parties (trafficking networks, old boys' networks) thus also tend to be avoided. ${ }^{3}$ 


\section{From a social theory to a systems theory of networks}

A general approach to examining networks already exists in sociology (Burt 1982; Granovetter 1973, 1985). Thus far, the theory has not yet been fully explored, it is rather a 'universal' method for formally analysing social structures (cf. Trezzini 1998); the central theoretical premises are, however, sufficiently robust to enable them to be examined critically. They give this approach the social-theoretical contours of a 'structural action theory' (Burt 1982): according to this approach, through their actions, agents always refer to other specific agents, and therefore in this way always enter into social relationships with one another that 'embed' their action (Granovetter 1985). Networks describe the structure of embedding action in social relationships, and hence social structure per se. It follows from the social-theoretical premises of the mutual composition of 'social action' and 'social relationships' that networks based on this approach appear as a phenomenon of absolute social necessity. ${ }^{4}$ It is then, however, virtually impossible to distinguish networks from other possible forms of social structure formation, such as organisations or interactions. The theoretical reason for this is that the basic concept of the theory already overlaps with the problem to be clarified, and is therefore overloaded. After all, the concept cannot assume the meaning of the composition of sociality, per se, as well as simultaneously describing a social phenomenon contingent in its occurrence. In general, avoiding analytical pitfalls of this kind presupposes the critical means that enables the basic concept to be separated from the problem: in other words, not answering the issue requiring clarification in the empirical sense that already resides in the basic concept.

It has been assumed that systems theory is unsuitable for research into networks (or even fails for this phenomenon) because it backs the basic concept of the operatively closed social system and, therefore, 'is irrelevant to the description of principally unlimited connections' (Hessinger et al. 2000: 66; similarly: Weyer 2000: 245). ${ }^{5}$ However, the advantage of systems theory is precisely that the concept of the network does not belong to the repertoire of its social-theoretical basic concepts (communication, system). The theory does not specify problems of social structural development from the focus of social theory, but from the perspective of the theory of society. As with other social-structural problems, this means that the question of networks must be clarified in the context of the theory of modern, functionally differentiated society.

It is, then, generally widely accepted that network formation - at least in modern society - assumes structures of functional differentiation. In what follows, this is explained by the proposal that social networks emerge from addresses, to be more precise: from the reflexive combination of the options and possibilities connected to the polycontexturality of social addresses in functionally differentiated society (cf. Tacke 2000; Bommes \& 
Tacke 2005). The assumption that networks emerge via the reflexive combination of addresses can be made from the social-theoretical network approach. Nevertheless, the systems-theoretical proposal cannot seamlessly align itself with the social-theoretical network approach. After all, the theory of social differentiation simultaneously suggests that networks in modern society are not a primary, but a secondary form of order formation that emerges from the primary structures of social differentiation. This hypothesis is drawn from the social primacy of a form of differentiation. This secondary form of order can then stabilise itself under certain conditions. This must be stated within any network theory.

Firstly, there will be a brief explanation of the role played by the primary social-theoretical differentiation structure for network formations, which is where social- and systems-theoretical concepts of the network differ. Then there will be an exploration of the emergence and stabilisation of networks via address combinatorics. Unlike in systems theory, no differentiation is made between modern society and its precursors in the social-theoretical network approach; congruent differentiations are even explicitly repudiated (Granovetter 1985). This is remarkable because in its basic assumptions, the network approach assumes what it denies: the socialstructural transition from a differentiated stratified society to a functionally differentiated society.

On the one hand, the social-theoretical network approach conveys the impression that it develops the notion of a primarily stratified, differentiated society because it concedes social-structural 'positions' and 'ties' (Thorelli 1986) a 'causal primacy' (Hessinger et al. 2000: 31). After all, it is relationships of social stratification, for which it is characteristic, that form the basis for social relationships being determined by hierarchies and affiliations. Furthermore, the conditions for participating in communication are accordingly determined by social-structurally defined status role sets (Burt 1982). On the other hand, a network theory in itself is only comprehensible as a reflection of the particularly modern understanding and experience that social and temporal connections and social-structural positionings become fluid in contemporary society. In other words, a network theory only makes sense under the conditions that social relationships are comprehended as having the ability to be created reflexively, rather than being determined through socio-structural processes.

The reflexive creation of networks, however, requires the release of social relationships from sweeping social conditionings (and hence conditions of functional differentiation). At the same time, this release from previous socio-structurally appointed positions and conditions for participating in communication in modern society is accompanied by a new set of conditionings and selective specifications of communications. As shown by the differentiation-theoretical tradition of Marx via Weber and Parsons and finally Luhmann, this conditioning is based on the meaning-logical 
differentiation and autonomisation of social sub-domains. As Max Weber saw it, 'social relationships' are 'adapted to one another according to their meaning' (Weber 1980: 13; Herv. MB/VT). As Luhmann phrases it socialtheoretically, with the meaning-logical differentiation of society they end up in the 'inclusion maelstrom of functional systems' (Luhmann 1997: 738), and are furthermore selectively conditioned by organisations and interactions in each specific manner.

The network theory, therefore, overlooks the fact that the transition from one social form of differentiation to another goes hand in hand with a radical change in the inclusion modes of individuals. Functional differentiation is only possible if individuals no longer take just one position in the social structure, which conditions all of their social possibilities (total inclusion), but instead participate in the differentiated contexts of communication (partial inclusions) from restricted perspectives on the basis of the 'release' of individuals from corporate ties (and hence conditions of exclusion).

At the same time, in modern society, this implies that each specific system context decides under which specific condition individuals will have their addresses used for communication and be considered relevant (inclusion) or irrelevant (exclusion) to the progress of the communication concerned (Luhmann 1995a: 241). The systems, namely functional systems, organisations and interactions, each regulate selectively and are independent; they decide on the content of the communication (for example campaigns or topics) and accordingly regulate which positions they give to individuals within this communication (Luhmann 1997: 738f). Since such positions, which make it possible to anticipate what to expect, change with the systems' references to meaning, they cannot be transferred arbitrarily from one system context to another: for instance, a leading position in science or art may not be able to substantiate a privileged position in law or the health system. ${ }^{6}$

The point at which network- and systems-theoretical descriptions clearly diverge is determined by the question of whether social participation by individuals is regulated primarily by their social-structural positions and ties (network) or primarily via communicative references to meaning (system). After all, the difference has far-reaching consequences: for example, social differentiation means that systems rationally emerge from each specific problem for which they then seek individual addresses (as well as organisations) and as attribution points for rationally specific messages. The socialtheoretical network theory does not assume such a primacy of the contextual problems, substantiated by its own logic of meaning, which then retrieves relevant addresses. ${ }^{7}$ Instead, it assumes a primacy of the social addresses in its social-theoretical renouncement of arguments of differentiation according to meaning. 
The separation of the two theories based on the process of participation of individuals does not imply that one theory may not inform the further development of the other. The systems theory can also support the understanding that networks take addresses as their primacy, at least in the empirical sense. This means, then, that a primacy of the addresses applies to the formation of networks. However, it does not apply to the formation of the primary systems - in other words, functional and organisation systems - in modern society. Unlike these systems, with their primacy of the problem for the search for addresses, networks can be established via the activation of addresses. The identification of problems and solutions, as well as all subsequent topics and developments are based on their primacy. The social-theoretical assumption of the primacy of the functional system differentiation is, in any case, not necessarily called into question by the empirically comprehended observation that the formation of functional and organisation systems (problems/addresses) and networks (addresses/problems) is a complementary phenomenon. Nevertheless, the complementary relationship between functional systems and organisations, on the one hand, and networks, on the other, should be understood asymmetrically insofar as the structure of modern society is based primarily on functional differentiation; network formations are types of secondary system formation. This will be explored in more detail below.

Network formations start with observations of how addresses can be combined, and develop from the opportunities that become available by pooling these addresses and facilitating communication. Assuming the primacy of the functional system differentiation enabling participation in communication and building contact lists, these opportunities are based on inclusions and exclusions in differentiated system contexts of society, their functional systems and organisations. The mutually supportive relationship between systems and networks already shows that the driving reason for the establishment of networks can be seen in the potential associated with linking heterogeneous opportunities, generated in different meaning and systems contexts, that may become accessible.

\section{Systems-theoretical network formation}

Although networks evolve through connecting addresses, they are not simply 'combinations of addresses' (Stichweh 2000b). In order to explain this, further clarification of what is understood by addresses is required, and also an understanding of which kind of addresses are possible for establishing networks and how networks are formed and stabilised by combining them. 


\section{Social addresses}

A social address is an attribution object generated for communication purposes, a more or less elaborated profile consisting of characteristics and behaviours with which personalised others are identified and equipped in the communication, and with which the communication operates as an assumption (cf. Luhmann 1995b; Fuchs 1997). Added to proper names, which are the basic characteristic of social addresses, are a multitude of further differentiations arising in the communication, which make them 'complex addresses' (Stichweh 2000b). One such differentiation is those components that are combined with addresses in everyday language and which lead to persons and organisations within the scope of availability: at least an address, usually a telephone number and increasingly an e-mail address. However, social addresses only gain contours through their individual profile of inclusion and exclusion, based on their records of participation in differentiated systems contexts, which hence simultaneously give insights into their relevance for further communications.

On the one hand, according to the social form of differentiation, addresses emerge 'polycontexturally' (cf. Fuchs 1997); they open up possibilities within the scope of their profiles, and simultaneously exclude others. On the other hand, they are not remembered and updated uniformly, but always selectively and dependent on context. The realm of possibilities for communication, and hence system-specifically constituted differentiations and attribution forms, are determined by this context dependency (unlike in network theory).

Social addresses are initially an ubiquitous phenomenon. They are a prerequisite when communicative meaning is assigned uniformly to a sender or recipient, i.e. if it is assigned to somebody who can comprehend the communication as a message instance (cf. Fuchs 1997; Stichweh 2000b). This may apply when the sender is representing an organisation or communicating as an individual. ${ }^{8}$ Since the formation of addresses is reliant on the presence of attributions in the communication, the communication continuously and inevitably produces addresses. In other words, social addresses are inextricably linked to participation in communications - and hence to the system-specific modes of inclusion. Because whenever communication takes place, inclusion occurs, and when inclusion takes place, communication therefore has addresses at its disposal. The reverse, however, does not necessarily apply by implication. After all, the communication can also make addresses its subject without including the 'somebody' around which the communication is based in the communication. In effect, addresses can then be updated completely unforeseeably in space and time. This can be seen from a simple example: 'Thank you for pointing that out. I will ask her if she can help me in this matter. Do you have her e-mail address?' 


\section{Address books and mobilisable addresses}

The starting point for network formations can be found in the reflexive conception of communication via addresses, as the simple example shows. An address is observed with regard to specific options that can be accessed via targeted addressing. Networks gain their specific potential through the reflective observation of the possibilities that attach themselves to addresses via system-specifically moderated inclusion and exclusion modes and that represent themselves - for one another - in the communication. Networks only differ from the primary systems, however, due to the fact that they particularly relate heterogeneous aspects to one another - i.e. possibilities created in different contexts of meaning. This can be seen more clearly when a differentiation is made between two types of address book and their relevance to network formations.

Address books arranged according to categories (directories) use the focus of media availability in the communication, but make the aspects of social addressability visible to only a minimum extent. A local telephone book is of no use if the caller does not know whom he wishes to call for what reason. Not everyone can be categorised. The Yellow Pages are also arranged according to categories. The directory orders addresses under more specific aspects of addressability which, if nothing else, point to the functional differences in meaning of the social differentiation structure (producer, physician, solicitor, etc.). The respective descriptors simultaneously demonstrate that the ability to assign an address cannot be assumed in the other contexts.

Individual address books must be distinguished from address books arranged according to categories. What is meant by an address is an individual's address or an organisation's address that connects with a number of individuals via a single address. They are unique because each recorded address refers to a history behind the contact and a certain systems context, giving it a specific profile of 'addressability'. Individual address books not only contain mobilisable addresses, relevant to establishing networks, but also addresses that can be activated functionally. This enables a distinction to be made between the address of a physician listed in an individual address book and that of an acquaintance who happens to be a physician. The latter could therefore be approached informally if their professional expertise was required, but this would not be formally anticipated, as they had not been listed in a directory based on this function. The fact that the difference between functional and mobilisable addresses cannot be seen from the text of an address book shows that this difference must nevertheless enable communication to succeed, and can be further enabled when addresses are updated.

Uncategorised, individual address books are the starting point and foundation for establishing networks. This simultaneously implies that merely 
linking addresses cannot yet be called a network. Although modern society features an increasing degree of availability and enormous complexity with regard to organising addresses, ${ }^{9}$ such 'address connections' (Stichweh 2000b) still do not constitute a network - either in referencing scientific citations to other scientific citations, or in the form of being able to list 1,000 or more persons as acquaintances. Even if only minimal requirements are made regarding a sociological concept of the network that can empirically capture even highly transient forms of network, simple address connections, individual address books and networks must be treated as separate. Networks are not merely references by technical, categorical or individual addresses to other addresses.

\section{Network constitution and stability}

The pool of individual addresses that can be mobilised to establish networks is characterised by random circumstances that cannot be predetermined. Although the polycontexturally based inclusion profile of each address restricts the possibilities, unpredictable options can also always be discovered and updated within the profile. For example, you might discover that a former fellow student lives in the city where you're in search of a flat; or, it might occur to a professor that he could contact his brother to arrange a work placement for his student at a television broadcasting company.

Access to the discovered possibilities and the initiation of networks is precarious. After so many years would it be appropriate to ask the fellow student if she would help you to look for a flat? The reason for the precarious starting point is that mutual favours are initially connected to the context that defines them: fellow students help each other with their studies, but do not necessarily arrange accommodation. The request for access to the cross-context possibilities discovered in an address is not necessarily a socially supported norm because the two possibilities are unrelated on a contextual basis. The risk of such a communication lies in the anticipated rejection of the unreasonable demand and in the observation as an 'illegitimate' request for linking heterogeneous possibilities.

If the risk is taken and there is a positive outcome, then further possibilities might be explored within the profiles of addresses, and they, in turn, could lead to reciprocal requests. It can generally be assumed that the selfenforcement effects of the communication, once uncertainty has been absorbed (cf. Japp 1992), contribute to the fact that the serendipity of the establishment of networks can sustain them. However, the way in which society, context and time contribute to the self-stabilisation of the network must be investigated in further detail.

Whilst the diversity and accessibility of the addresses initially present a potential barrier to the launch and establishment of a network, once this barrier has been overcome, it will become the bedrock and the driving 
force behind the network's stability. The problem of organising assistance, contacts, access, advice, etc., made collectively available by the participants is resolved over the course of time: reimbursement for the services received will inevitably take place at a later point in time, and any service rendered constitutes a 'credit' for a non-specified return service in the future (Gouldner 1960). The necessarily unspecified character of such return services and their non-predefined scope - after all, it is not a matter of exchanging equivalents - constitute the ongoing continual presence of an overhang, a 'constantly remaining obligation' (Luhmann 1997: 653) following such a return service. In other words: the polycontexturality of this arrangement constitutes the foundation for the development of a generalised expectation of reciprocity. Viewed operationally, this expectation facilitates the continuation and stability of the initiated network formation, and is therefore able to secure its validity and high degree of flexibility in various contexts (ibid.).

This implies that it is not enough to define generalised reciprocity as an essential principle of networks in order to define their emergence and ability to self-stabilise (as suggested, however, by Powell 1990 and Mahnkopf 1994). Although this form of generalised reciprocity (Gouldner 1960) does initially facilitate the operational stability and continuation of networks, this is only possible on the basis of the 'combination of temporal and social asymmetry' (Luhmann 1997: 652). In other words, and as has been shown, the expectation of reciprocity precedes the social network constitution in the previously described meaning of overcoming a barrier, which is then followed by a time of stabilisation and establishment over time on the basis of reciprocity.

Particularly because the social composition of networks under modern conditions is based on the connection of heterogeneous addresses, the continuation of this reciprocity is subject to considerable assumptions. Under these informal social conditions, reciprocity cannot be based on pre-regulated or externally imposed fixed reference points. ${ }^{10}$ Networks in modern society that are based on the release of social addresses and are particularly initiated due to social opportunities ${ }^{11}$ must take care of themselves in all their dimensions of meaning - in other words, socially, contextually and temporally, i.e. they must 'gain conditionings on the basis of reciprocity that can be maintained over the course of time' (ibid.: 653).

The communication of reciprocal expectations of services characterises the functional mode of networks: rendering services with regard to other future services yet to be determined. Contextually, this can range from assistance and support within neighbourhood networks to innovation networks initiated by organisations (Kowol \& Krohn 1995). In both cases, an emergent service result is rendered possible via the improbable exchange of heterogeneous individual services, whether concerning new products or technologies or, alternatively, improving welfare provided by neither the 
market nor the state. However, it has not yet been clarified how this mode secures its own connectivity, and hence the continuation of the network communication.

\section{The tendency to expand and the need for restriction}

As already shown, networks emerge once the barriers to their establishment have been overcome. They enable the improbable to happen by combining contextually incompatible aspects with one another, made possible by linking addresses. This is where they find their opportunity to emerge. In turn, however, the communication form of reciprocity does not contain any criteria of the contextual restriction (Gouldner 1960: 175). In this sense, it is unpredictable in that, once established, it has a tendency to spread to everything unchecked. For this reason, networks are initially subject to a contextual tendency and then also dependent on social behaviour to expand, because the formal mechanism of reciprocity does not principally allow for a stop rule: the more intensive the network communication, the less specific the opportunities regarding the creation of mutual expectations of services. ${ }^{12}$ This substantiates a contextual and a social risk of overload. For this reason, it can be assumed that numerous networks will disintegrate shortly after their initiation because the potential participants shy away from the expected expansion of the network, which is why continuous network inclusion fails. ${ }^{13}$ After all, the principle of including participants in network communication basically consists of the expectation of participation in the reciprocal rendering of services with reference to a limited range of addresses.

How do networks succeed then in restricting their contextual and social scope and, in so doing, deal with the contextual and social risk of overload by excessive growth? Networks can evidently limit their growth by remaining focused on the original reasons for their foundation in the first place. This can lead to problems for newcomers who find it hard to gain a foothold in socially exclusive, established networks. Difficulties can also emerge when the networks' original purpose was broad in scope, e.g. innovation networks, regional business development networks, migration networks, neighbourhood networks and women's networks. The contextual meaning which inspires the formation of the network then defines its contextual scope. Assuming this, criteria can then be developed concerning which addresses are potential participants in the network. Such initial selfstructuring may possibly succeed in engaging potential participants for the continuance of an emergent network using the combination of social and temporal asymmetry.

In local community networks, problems specifically associated with everyday lives in private households typically become the focal point for expectations that can be communicated and constructed within the 
framework of the reciprocity rule. It is generally a matter of overcoming temporary situations of shortages of food and other household items, communication problems, looking after and caring for children and the elderly, limited mobility, security or building or technical repairs or developments. In this respect, local community networks develop a variably deep and farreaching intensity through their own legacy and experience, which is stabilised through repetition and which can then at the same time serve as a restriction. In the social dimension, they are primarily based on spatial and temporal inclusivity and availability criteria, thus restricting its social reach. $^{14}$

In scientific networks and most forms of organisational networks, their origins serve not only as the criteria for the contextual range of reciprocity, but also for the inclusion of addresses. In scientists' networks, their functional starting point does not generally include helping each other overcome routine, everyday problems, thereby restricting the network's contextual possibilities for expansion. Accordingly, the ability to make such contributions does not substantiate participation in the network either. The specific contextual and social orientation and selectivity of organisational networks can be seen from the names they are typically given, such as supplier or innovation networks.

By comparison, it is particularly evident in the example of illegal immigration networks that networks are nonetheless able to expand their context considerably: they provide information about transport, communication, accommodation, gainful employment, health, law, power ${ }^{15}$ and a wide range of assistance to help participants lead their everyday lives (cf. Müller-Mahn 2000). These networks construe the reciprocity mechanism expansively in the contextual dimension based on the foundation of their underlying problem - immigration. ${ }^{16}$ At the same time, this justifies the intrusive and unreasonable demand content of such networks that can affect the entire lifestyle of participants. They tend to recruit and retain participants in an unforeseeable manner by influencing a broad sweep of their lives, leading simultaneously to social expansion. If nothing else, the status of being an illegal immigrant restricts the possibilities of withdrawal, since the ability to use services in organisations within the functional system is reliant in many cases on inclusion in the networks, and hence continues the inclusion in respective expectations, because no alternatives are open to them. ${ }^{17}$

A further potential restriction to fulfilment lies in the combination of the particular conditions of the contextual meaning dimensions of networks with formal reciprocity as their specific communicative form, which is a barrier to participants prospering in their own right. This demonstrates that reciprocity is hence reliant upon probatory participation in social and temporal terms. Temporally, each service rendered is met with a return service in the future, which alone restricts the possibility of the expansive 
communication of further expectations of service: a certain degree of redundancy is probable as a prerequisite for variance in the meaning of the increase in the effectiveness of networks.

Providing a return service in the future simultaneously signifies social probation. This forms the basis for nurturing trust and gives insights into addresses once more is known about the character of the individual. But here, too, the following applies: growth in terms of the increase and variance of the addresses facilitates an increase in the combined possibilities, but also brings with it the risk of weakening the mechanism of trust with regard to social obligations (likely to be stronger in smaller, more intimate networks) and the expectations of reciprocity and the focus of the network. The closure and restriction of participation in the network therefore increases the mutual ties and exclusivity of participation, but limits the opportunities of future combination gains (cf. Granovetter 1973).

In their structural development, therefore, networks are based on their eventual redundancy. This allows them to strengthen and therefore, at the same time, to test and limit their variation leeway from a social and contextual aspect. In other words: in this fundamental reflexive reference to the contextual and social dimension, the potential of networks lies in their dynamic stabilisation through the facilitation of growth and social selfextension on the basis of eventual restriction and social closure.

Structural formation in networks is the result of their balancing variance and redundancy. Their contextual starting point requires temporal and social confirmation as the foundation for maximising their effectiveness with regard to access to improbable possibilities. As such, their starting point substantiates their path dependence in the realisation of their potential which, over time, is more or less brought to bear in the definition of the enhancement relationship between redundancy and variety. As already shown, the incentive to establish networks exists in creating improbable combinations of possibilities. They therefore result in highly specific services for their members, arising from the combinatorics of these possibilities under the structural conditions of the network formation and their stabilisation in the described sense. For this reason, networks are inevitably particular: they emerge in response to particular opportunities, and apply their inner structure formation onto them on the basis of generalised reciprocity and the associated stabilising influences. They then go on to develop their specific achievement potential on this basis. After all, although an 'objectification' takes place in the process of network formation, enabling contextual criteria and problem references to be created and stabilised (which frequently lend their names to networks), the barrier to universalisation/generalisation cannot be overstepped, owing to the particular constitution and self-embedding of networks. ${ }^{18}$

Networks gain social cohesion from the address characteristics of certain persons, contextual cohesion from the highly specified services to be 
arranged via them and temporal cohesion due to the reciprocal relationships created and confirmed between members. The operation and inclusion framework of networks are the formal communicative conditions under which they can be observed. On this basis, they can emerge - and dissolve again - in virtually any arbitrary social context. Some networks are more permanent than others, not due to their reciprocal operation mode alone (which characterises all of them), but due to the fact that the particular starting conditions are used reflexively to create structures in the described manner, securing the connectivity communication within the network.

In summary, this can be worded as follows: the ability to link up heterogeneous and therefore contextually unconnected services, accessible via addresses, through reciprocity and the creation of a network-specific range of services is essential for networks. Connecting heterogeneous elements therefore does not find coherence in itself beyond the particular motive, but is only required for initiating reciprocity, which, in turn, is anchorless: contextually, as long as it is lacking a specified criterion of restriction; socially, as long as it is not embedded in any institutionalised social position or role, and thus backed by it, but merely through its 'circumstance'. This reveals the modernity of networks beyond the condition of the release of social addresses: networks gain support in neither status nor roles, nor in the social form of differentiation.

In this sense, networks apparently manage to stabilise themselves by connecting several particular selections through reciprocity, which brings them, as it were, into a relationship of mutual support, and thus self-supporting structural formation. This justifies the significance of balancing out the relationship between redundancy and variety in networks. Not everything can be varied at the same time in such a supportive, inter-connected arrangement: contextual enhancement must prove itself socially and temporally; social variation must prove itself contextually and temporally; and, finally, temporal variation has to prove itself socially and contextually. Against this backdrop, it can then be deduced that all structures of the network - its participants, its obligations, its specific range of services, its time relationships - are its own creation. ${ }^{19}$

\section{Forms of self-simplification}

Social networks primarily communicate expectations of reciprocity in a continuous, implicit fashion; but they are also based on explicit selfdescriptions which are connected to various possibilities of the self-simplification of their self-created structures. One form of self-simplification is the names they give themselves, which are used not only within the network, but often also in the way in which they portray themselves to the public. 
A name such as Netzwerk Frauenforschung NRW (Women's Research Network North Rhein Westphalia) recognisably refers to two contextual references at the same time: science and politics. The reference to 'women' oscillates, on the one hand, between the policy dimension (equal opportunities, in a German federal state) and the academic dimension (gender studies). On the other hand, the reference also complies with the inclusion dimension of the network (it is not intended that men will participate). According to the way it presents itself externally, the network consists of 'female network professors' with accessible university addresses. ${ }^{20}$ However, neither the factual conditions of reciprocity in the network nor the prerequisites of political success are described in its self-portrayal. What is also presupposed, because of its positioning between science and politics, is a set of organised, available network addresses from political bodies that have accessible resources and that participate in the network in the temporally, contextually and socially restricted mode of the communication of reciprocity. However, they do not appear as addresses in the 'network', with the exception of the reference to a former minister who noticeably makes use of the aspect of a foundation myth in the self-portrayal. This alone shows that the conditions present in the presentation and creation of networks can diverge to a lesser or greater extent. Its self-proclaimed scope as a 'women's research network' is attached to a functional (scientific research) and a universal viewpoint (equal opportunities for women), which gives the process legitimacy. Its framework, however, latently implies the fact that both the general reciprocity-assisted operational basis and, in particular, the principle of self-endorsement and the statusrelated exclusivity of participation also turn this network, in essence, into a particularistic structure formation.

In contrast, a self-generated model in which 'men' combine certain services into a 'network' cannot expect to be met with comparable responses and legitimacy that political and public organisations engender. The respective improbability of such a model does not, however, indicate that the creation of networks established on the basis of the recognisably ascriptive feature of being 'male' must fail. They are by all means empirically detectable. Comparatively, however, it is interesting to note that in such networks, the address aspect of gender need not be communicated as the subject and the declared exclusion criterion. In fact, the gender-related selective inclusion in the network can be based on the reference to bodies disengaged from communication (sports, sauna), where the communicative 'no' is avoided or made invisible (Stichweh 2004: 355ff.). Analogously, for instance, the communication does not imply whether regular university 'professor's football' serves the purpose of creating and fostering a genderhomogeneous corporate network in addition to its portrayable function of regular recreational sport amongst colleagues, which selectively imposes 
its 'physically' based - in both senses of the word - social ties in the organisational decision-making process.

However, networks can also simplify their conditions by myths associated with them, such as by referring to themselves as 'fraternities' or 'bonds of friendship' or by invoking kinship or ethnicity as primary ties. The secondary forms of reflexive stabilisation can also expand or restrict the scope of possibilities and the flexibility of the network ${ }^{21}$ in these cases, too, by furnishing it with structures of the portrayal of its boundaries in a contextual, social or spatial respect. This is frequently overlooked in network research, too.

In research about migration, for instance, the task of precisely defining networks is frequently circumvented by calling them ethnic or kinship networks. Research thus assumes the self-simplifications of networks - as though everything is implied by the labels. However, the meaning of the concept of the network in modern global society is that it presents the prospect of capturing a structure of social relationships that tend to be absolved from conditions of close proximity and the social vitality of interactions. As shown, social systems provide social networks with their opportunities for establishment and growth; in other words, they require the social structural contexts from which they emerge. This paves the way for the spatial decontextualisation and, potentially, the global operational mode of networks restricted by their own dimensions (Stichweh 2000c). By linking addresses, networks combine the contextual possibilities available to the individuals belonging to the networks. The reference to space (neighbourhood, regional origin) and social proximity (within the sense of kinship and ethnic community building) enables networks to be stabilised through simplification. This, however, should not be confused with theoretically and empirically genetic and structural issues. Networks may primarily emerge and spread through the medium of collectivisation mechanisms, such as family and relations, or spatial indexing, such as urban districts or origin: performances in connection with realising a migration project can be expected on the basis of affiliation to a kin, ethnic group or local area. Reciprocity then initially finds some kind of external support in the (former) inclusion of migrants in socio-structurally embedded reciprocity relationships (Thomas \& Znaniecki 1958; Schiffauer 1987). With the creation and continuation of such networks, however, it now becomes important for this external support to be substituted by the process of reciprocity, generated internally by the network itself, in order for it to thrive. The networks' moral obligation of reciprocity learns lessons from peasant society in which a collective approach was applied in order to survive times of hardship. However, this approach is made vulnerable if the variation in addresses is too excessive. And this is particularly the case in migration networks because the participants may provide one another with transport, jobs, accommodation, the power of enforcement, legal advice, training, 
media access, solace, medical treatment or assistance. In the development of a network, therefore, the self-created obligation of reciprocity replaces the moral obligation content, which was embedded externally in the previous circumstances. This obligation of reciprocity is based on various services which, if not fulfilled, however, make the further inclusion in a network's range of services more improbable due to the loss of trust. Relatives and people with shared nationalities can then become 'tiresome' and be confronted with more and more requests, based on previous 'credits' or increasingly withdraw from them 'ashamedly' with feelings of guilt. In other words, when networks are initiated through genetic connections, through relatives, regional or ethnic affiliation or other forms of collectivisation, this does not structurally change the fact that they remain reliant on their own support mechanisms within the structural context of functional differentiation and have to adapt the conditions with which they started in order to develop.

\section{Delineation and system formation}

By analysing the debate set out above, the inevitable conclusion is that networks, strictly speaking, should be regarded as social systems. Their characteristics of fluidity and flexibility seem, however, to contradict this idea, which, in addition to their proliferation, ${ }^{22}$ is repeatedly produced in the general discussion about networks, which assesses their particularities and strengths. These features, however, can only be comprehended on the basis of the characterisation of the particularities of structure formation in networks outlined above, because it enables us to understand how stability can be achieved whilst, at the same time, enabling path-dependent flexibility and fluidity from contextual, social and temporal perspectives. Basically, a network consists of nothing other than recursive, reciprocal service communication. Its fluidity is a result of the fact that within this communication, no extensive, explicit definitions can be made, because this would destroy the structural basis of the efficiency of the network, i.e. the functionality of reciprocity: in contextual terms, no explicit definition is possible in the long run - this and not that; in social terms, no explicit definition can be given in the long run - this one and not that one; and in temporal terms, no explicit definition can be given in the long run - then and not earlier or later. ${ }^{23}$

The arrangement of the mutual interconnection of the contextual, social and temporal structures, and the associated stability and flexibility, has to justify its legitimacy in the course of the network's performance. Networks' boundaries therefore appear to be flowing in both contextual and social respects. After all, from their initial starting point, networks are in fact capable of dragging everything and everyone into their maelstrom, provided they fit into the self-reproducing structural arrangement as a 
potential service or address. The boundaries of networks appear to be more or less determined by context and social influences because, in principle, the whole contextual and social world can become the subject of network communication, bearing in mind their contribution to the network and their increasing scope of services on the basis of reciprocity. The evolving nature of boundaries, however, must not be mistaken for indetermination. Ostensibly, the characteristics of boundaries always concern only those parts of the world that are deemed to be their relevant environments on the basis of their structural arrangement, depending on the specific networks. Consequently, the fluidity of boundaries does not mean that they serve no purpose: a network establishes itself in the social world by performing its reciprocal communication which determines its membership during the course of this performance and on the basis of self-created structures. This can be subject to considerable fluctuations, and yet not necessarily become arbitrary. After all, although no sound criteria exist for this, the decision to continue the network communication itself constitutes the last criterion. Where communication ends, i.e. when a network dissolves, the construction of boundaries in terms of the function of sharing addresses and providing services now defunct, has failed. This is because the context has become blurred and trust can no longer be nurtured, i.e. the particular and structural arrangement of a network that justified itself during its performance has collapsed. It is possible for networks to disintegrate in this process, but they may be reactivated. From an operational point of view, however, this is not surprising because networks stop and are brought back to life, provided their basic model of the relevant communication of reciprocal expectations of services succeeds. In other words, they must be capable of making connections and enable boundaries to be drawn with regard to the aspects mentioned. ${ }^{24}$

Ultimately, difficulties in comprehending networks as social systems can be further resolved and eliminated by comparing them with other systems in modern society. Networks do not gain support in the contextual dimension, as with functional systems, nor in the social dimension, as with stratificatory systems; they also do not rely essentially on presence and the reflexivity of perception, unlike with interaction systems. The comparison with formal organisations, however, is quite revealing: similar to these organisations based on the recursive linking of decisions, networks form their structures by the recursive combination of expectations of reciprocity. In contrast to other organisations, however, which can essentially make anything the subject of decisions, networks remain inevitably bound to their particular starting point, linking heterogeneous addresses and the services procured through them. Decisions can be made a subject of decisions; thus, in organisations, everything can be formally negotiated. By contrast, it is not obvious how reciprocity would be applied to itself in networks. And even if this was possible, it is not clear how it would manage to modify or 
eliminate the particular starting point as a basis for further structure formation. For this reason, networks are unable to establish themselves formally in the way that organisations do. Instead, strangely enough, their formation is based on the interconnection of universalism and particularism: on the possibility of combining addresses based on their universal release under conditions of functional differentiation; each specific combination and the resulting performance content, however, are inevitably particular. Operating under conditions of functional differentiation, this is the reason for the potential fragility of networks: they only gain support from within, embedded in the specific combination and inter-relationship of social, contextual and temporal structures applicable only to them. This makes networks somehow arbitrary and universal at the same time: they appear everywhere. They are ephemeral: they emerge, vanish and come to life again. This makes it difficult to grasp this universally applicable possibility of network emergence in functionally differentiated society and to understand that the rapid emergence and disappearance of systems - as with their flexibility and fluidity - does not contradict the fact that they are, indeed, social systems.

\section{Conclusion}

Finally, it must be borne in mind that the present determination of the system formation of networks and the mode of their structure formation does not answer the question regarding which structures of modern society are more likely to establish networks and what they actually achieve as secondary structure formations in modern society, i.e. beyond each individual network's specific scope of services. After all, they appear to some extent to materialise in structural spaces that pervade modern society. There is virtually no other way to explain their ubiquity: they are, after all, secondary system formations. As an independent analytical task, however, we can only focus on this adequately by taking the concept of the network devised here into account. The proposal for such a concept put forward here therefore constitutes a research programme for the authors. ${ }^{25}$

\section{Notes}

I Meier and Krücken (2003) emphasise the side of the semantic economy and portrayal of 'network' without, however, allowing for structural issues of their construction within the framework of their neo-institutionalist argument (network as a new 'rationality myth').

2 The contribution by social sciences is remarkable here, too: for instance, Powell (1990) talks of networks as social relationships that are 'more social' than other 
social relationships because in networks socialisation is not based on the market (prices) or hierarchy (orders), but on solidarity (trust).

In the first part of the present article, reference is made to arguments published previously by the authors elsewhere (Tacke 2000, 200I; Bommes \& Tacke 2005). The second part of the present text, however, goes beyond this status of the argument, particularly with the proposal to describe networks as systems (unlike in Tacke 2000).

4 Advocates of this approach may see a simplification in this, provided they tend to assume that, in addition to networks, social relationships also exist that are 'less social' than those in social networks. What is typically meant by this is that markets and hierarchies are objectified contexts of social aspects, according to Weber. If this should be taken into account, however, conversely the concept of the network can theoretically no longer stand for the constitution of sociality, per se, at least not without clarifying the relationship between the contextual, temporal and social dimensions.

5 But why, one asks oneself, do social networks depart from social systems - they will at least have to adhere to this boundary. They need not be called systems, but it is impossible to avoid creating a boundary between social and non-social aspects.

6 This does not mean that transfers of this kind cannot occur empirically, but rather that if they do occur, sociology faces special challenges to explain them.

7 And then, yet, implicitly or formally: strong ties (same context of meaning), weak ties (heterogeneous contexts of meaning).

8 However, this is not the case with functional systems or interaction systems. It is impossible to address 'the' economy or 'the' politics. And the attempt to address an interaction system leads to the person concerned becoming involved in the interaction (or being ignored).

9 This has become the subject of extensive research under the term 'small world' (Milgram 1967; Watts 1999). In this research, the accessibility of addresses (target persons) via known addresses is investigated in experimental studies. 'Small world' emphasises that only very few 'intermediaries' are required to successfully reach and address arbitrary addresses throughout the world via acquaintanceship connections.

Io For instance, the expectations of reciprocity are embedded in differentiated segments of societies in the form of differentiation; they correspond to the consistency of the sub-systems (families, clans, etc.) within which the social possibilities of the individual are defined on the basis of gender and generation. Here, reciprocity does not substantiate networks that require the release of addresses either - but which are therefore open with regard to their social composition.

II They do not support the form of differentiation, but are established secondary to it.

I2 In this context, let us not forget the networking potential late nights at the pub may have during academic conferences or the significance of a lack of fences between neighbouring properties.

I3 Here, too, we can tell how it differs from the significance of expectations of reciprocity in pre-modern social structures: the rejection of a 'donation', and the immediate compensation for a service by a return service, and thus avoiding the emergence or continuation of expectations of reciprocity are available as social possibilities.

I4 This can be seen, for example, when a person moves away from a neighbourhood: can you still make use of the typical services within the network, and if so for how long, e.g. if the washing machine breaks down, or are you now reliant on functional alternatives (laundrette) despite the continued spatial advantages?

I5 Which can be seen, for instance, in 'bands' that collect wage payments that may, if in doubt, be owing on informal labour markets. 
I6 If migration is understood to be a form of geographic mobility to realise inclusion opportunities (Bommes 1999), it is understandable that the performance of these migration networks consists of conveying such opportunities, which is why they tend to have a contextual and accordingly extensive and expansive design.

I7 It is hardly surprising, as observed repeatedly from interviews with migrants, that they attempt to leave such network bonds and their wide-ranging obligatory character once alternatives open up and they gain a legal status (Alt 1999, 2003; Anderson 2003). The foundation for this is not least the opportunity to assume formal functional or performance roles, access to which, however, often requires obtaining a legal status. Compare the case study by Müller-Mahn (2000).

I8 Even if 'self-supporting' network structures emerge that complement their contextual restriction in accordance with structure-like addresses (cf. Müller-Mahn 2000, Tacke 2000).

I9 Which does not affect the argument that networks obtain their services from other systems - because their significance and relevance in the available range of services are created by the network itself.

20 This restriction to the participants' status of professor underlines the aspect of public and political profiling - of self-portrayal. Young academics, including the female employees of 'female network professors', are referred to a secondary network.

2I Ethnicity, then, restricts social accessibility, but may simultaneously enable the members' expectations of performance to be expanded. At the same time, depending on the social positions accessible to the members of an ethnic group in different functional systems and their organisations, a restriction of the network's range of services can also be linked to it.

22 It is easy to see their ubiquity with the network concept presented here: in the establishment phase, they rely on a general mechanism that is universally applicable to a large number of particular opportunities in modern society.

23 This also holds true if networks use their contextual starting point to restrict expansion in a contextual respect, because then it is relatively clear that no general advice on leading lives is provided in scientists' networks - but this, by contrast, does not allow for any positive preliminary determination of the scope of services - this remains open at the level defined by the network communication. In the same way, although a women's network stipulates that participation by men is socially unlikely, the addresses of women who might participate in it are not yet determined.

24 The speech on reactivation explains this: the communication has to know how it works.

25 Incidentally, this alone is not seriously argued against the fact that conflicts are social systems. They emerge and disappear again for a more or less long duration, the success of which is dependent upon their stabilisation by exploiting the structure formation possibilities of their equally particular possibilities of emergence.

\section{References}

Alt, Jörg (1999), Illegal in Deutschland. Forschungsprojekt zur Lebenssituation 'illegaler' Migranten in Leipzig. Karlsruhe: Von-Loeper-Literaturverlag.

Alt, Jörg (2003), Leben in der Schattenwelt. Problemkomplex illegale Migration. Karlsruhe: Von-Loeper-Literaturverlag.

Anderson, Philip (1998), In a Twilight World: Undocumented Migrants in the United Kingdom. London: Jesuit Refugee Service.

Anderson, Philip (2003), 'Dass sie uns nicht vergessen'. Menschen in der Illegalität in München. Munich: City Council of Munich 
Bommes, Michael (1996), 'Ausbildung in Großbetrieben. Einige Gründe, warum ausländische Jugendliche weniger Berücksichtigung finden', in Ralf Kersten, Doron Kiesel \& Sener Sargut (eds), Ausbilden statt Ausgrenzen. Jugendliche ausländischer Herkunft in Schule, Ausbildung und Beruf. Frankfurt am Main: Haag und Herchen, pp. 31-44.

Bommes, Michael \& Veronika Tacke (2005), 'Systems and Networks: Competing Theories or Complementary Social Structures?' in David Seidl \& Kai Helge Becker (eds), Niklas Luhmann and Organization Studies. Copenhagen: Copenhagen Business School Press.

Burt, Ronald S. (1982), Towards a Structural Theory of Action. Network Models of Social Structure, Perceptions, and Action. New York: Academic Press.

Fuchs, Peter (1997), 'Adressabilität als Grundbegriff der soziologischen Systemtheorie', Soziale Systeme. Zeitschrift für soziologische Theorie, Vol. 3, Issue 1, p. 57-79.

Gouldner, A. (1960), 'The Norm of Reciprocity: A Preliminary Statement', American Sociological Review, Vol. 25, Issue 2, pp. 171-178.

Grabher, Gernot (1993), The Embedded Firm: On the Socio-Economics of Industrial Networks. New York: Routledge.

Granovetter, Marc (1973), 'The Strength of Weak Ties', American Journal of Sociology, Vol. 78, Issue 6, pp. 1360-1380.

Granovetter, Marc (1985), 'Economic Action and Social Structure: The Problem of Embeddedness', American Journal of Sociology, Vol. 91, Issue 3, pp. 481-510.

Hessinger, Philipp, Friedhelm Eichhorn, Jürgen Feldhoff \& Gert Schmidt (2000), Fokus und Balance. Aufbau und Wachstum industrieller Netzwerke. Opladen: Westdeutscher Verlag.

Japp, Klaus P. (1992), 'Selbstverstärkungseffekte riskanter Entscheidungen. Zum Verhältnis von Rationalität und Risiko', Zeitschrift für Soziologie, Vol. 21, pp. 31-48.

Kenis, Patrick \& Volker Schneider (1996), Organisation und Netzwerk. Institutionelle Steuerung in Wirtschaft und Politik. Frankfurt am Main, New York: Campus.

Kowol, Uli \& Wolfgang Krohn (1995), 'Innovationsnetzwerke. Ein Modell der Technikgenese', in Jost Halfmann, Gotthard Bechmann \& Werner Rammert (eds), Theoriebausteine der Techniksoziologie. Jahrbuch 'Technik und Gesellschaft' 8. Frankfurt am Main, New York: Campus, pp. 749-760.

Luhmann, Niklas (1980), 'Gesellschaftliche Struktur und semantische Tradition', in Niklas Luhmann, Gesellschaftsstruktur und Semantik. Studien zur Wissenssoziologie der modernen Gesellschaft. Vol. 1. Frankfurt am Main: Suhrkamp, pp. 9-71.

Luhmann, Niklas (1995a), 'Inklusion und Exklusion', in Niklas Luhmann (ed.), Soziologische Aufklärung 6. Die Soziologie und der Mensch. Opladen: Westdeutscher Verlag, pp. 237264.

Luhmann, Niklas (1995b), 'Die Form Person', in Niklas Luhmann (ed.), Soziologische Aufklärung 6. Die Soziologie und der Mensch. Opladen: Westdeutscher Verlag, pp. 142154.

Luhmann, N. (1997), Die Gesellschaft der Gesellschaft, 2 vols. Frankfurt am Main: Suhrkamp.

Mahnkopf, Birgit (1994), 'Markt, Hierarchie und soziale Beziehungen. Zur Bedeutung reziproker Marktgesellschaften', in Nils Beckenbach \& Werner van Treeck (eds), Umbrüche gesellschaftlicher Arbeit. Soziale Welt. Special Volume 9. Göttingen: Schwartz, pp. 65-84.

Mayntz, Renate (1993), 'Policy-Netzwerke und die Logik von Verhandlungssystemen', in Adrienne Héritier (ed.), Policy-Analyse. Kritik und Neuorientierung. PVS Special Edition 24. Opladen: Westdeutscher Verlag, pp. 39-56.

Meier, Frank \& Georg Krücken (2003), 'Wir sind alle überzeugte Netzwerktäter', Soziale Welt, Vol. 54, pp. 71-92.

Milgram, Stanley (1967), 'The Small World Problem', Psychology Today, Vol. 1, pp. 61-67.

Müller-Mahn, Detlef (2000), 'Ein Ägyptisches Dorf in Paris. Eine empirische Fallstudie zur Süd-Nord-Migration am Beispiel Ägyptischer "Sans-Papiers" ' in Frankreich', IMISBeiträge 15. University of Osnabrück. 
Powell, Walter W. (1990), 'Neither Market nor Hierarchy. Network Forms of Organization', Research in Organizational Behaviour, Vol. 12, pp. 295-336.

Schiffauer, Werner (1987), Die Bauern von Subay. Das Leben in einem türkischen Dorf. Stuttgart: Klett-Cotta.

Stichweh, Rudolf (2000a), 'Semantik und Sozialstruktur: Zur Logik einer system-theoretischen Unterscheidung', Soziale Systeme, Vol. 6, Issue 2, pp. 237-251.

Stichweh, Rudolf (2000b), 'Adresse und Lokalisierung in einem globalen Kommunikationssystem', in Rudolf Stichweh, Die Weltgesellschaft. Soziologische Analysen. Frankfurt: Suhrkamp, pp. 220-231.

Stichweh, Rudolf (2000c), 'Zur Genese der Weltgesellschaft: Innovationen und Mechanismen', in Rudolf Stichweh, Die Weltgesellschaft. Soziologische Analysen. Frankfurt: Suhrkamp, pp. 245-267.

Stichweh, Rudolf (2004), 'Zum Verhältnis von Differenzierungstheorie und Ungleichheitsforschung am Beispiel der Systemtheorie der Exklusion', in Thomas Schwinn (ed.), Differenzierung und soziale Ungleichheit. Die zwei Soziologien und ihre Verknüpfung. Frankfurt am Main: Humanities online, pp. 353-367.

Sydow, Jörg \& Arnold Windeler (eds) (1994), Management interorganisationaler Beziehungen. Opladen: Westdeutscher Verlag.

Tacke, Veronika (2000), 'Netzwerk und Adresse. Soziale Systeme', Zeitschrift für Soziologische Theorie, Vol. 6, Issue 2, pp. 291-320.

Teubner, Gunther (1992), 'Die vielköpfige Hydra: Netzwerke als kollektive Akteure höherer Ordnung', in Wolfgang Krohn \& Günther Küppers (eds), Emergenz: Die Entstehung von Ordnung, Organisation und Bedeutung. Frankfurt am Main: Suhrkamp, pp. 189-216.

Teubner, Gunther (2002), 'Hybrid Laws: Constitutionalizing Private Governance Networks', in Philip Selznick \& R. Kagan \& K. Winston et al. (eds), Legality and Community: On the Intellectual Legacy of Philip Selznick. Lanham, MD: Rowman \& Littlefield.

Thomas, William I. \& Florian Znaniecki (1958), The Polish Peasant in Europe and America (first published in 1918/1921). New York: Dover Publications.

Thorelli, Hans B. (1986), 'Networks: Between Markets and Hierarchies', Strategic Management Journal, Vol. 7, Issue 1, pp. 37-51.

Trezzini, Bruno (1998), 'Konzepte und Methoden der sozialwissenschaftlichen Netzwerkanalyse: Ein aktueller Überblick', Zeitschrift für Soziologie, Vol. 27, Issue 5, pp. 378-394.

Watts, Duncan J. (1999), 'Networks, Dynamics, and the Small World Phenomenon', American Journal of Sociology, Vol. 105, Issue 2, pp. 493-527.

Weber, Max (1980), Wirtschaft und Gesellschaft, $5^{\text {th }}$ edition. Tübingen: Mohr.

Weyer, Johannes (2000), 'Soziale Netzwerke als Mikro-Makro-Scharnier. Fragen an die soziologische Theorie', in Johannes Weyer (ed.), Soziale Netzwerke. Konzepte und Methoden der sozialwissenschaftlichen Netzwerkforschung. Munich: Oldenbourg, pp. 237-254.

Williamson, Oliver E. (1996), 'Vergleichende ökonomische Organisationsforschung. Die Analyse diskreter Strukturalternativen', in Patrick Kenis \& Volker Schneider (eds), Organisation und Netzwerk. Institutionelle Steuerung in Wirtschaft und Politik. Frankfurt, New York: Campus, pp. 167-212. 



\section{National paradigms of migration research (with Dietrich Thränhardt)}

First published in 2010 by $V \& R$ unipress as the chapter 'Introduction: National Paradigms of Migration Research' (pages 9-38), co-authored with Dietrich Thränhardt, in National Paradigms of Migration Research (IMISSchriften 13), edited by Michael Bommes and Dietrich Thränhardt

Reprinted in 2011 as 'Nationale Paradigmen der Migrationsforschung', in 'Migration und Migrationsforschung in der modernen Gesellschaft' in IMISBeiträge 38 (pages 11-48)

Migrations are an inherent part of current processes of globalisation and internationalisation, which undoubtedly provide the foundation for the increasing call for more international and comparative research. Accordingly, the number of international research projects and networks in the research area of migration has grown considerably over the last two decades. ${ }^{1}$ Scholars participating in this endeavour, however, soon discover that the academic modes of conceptualising, defining and recording problems depend to a large extent on the respective national histories of science. This applies particularly to academic research into international migration and the ensuing problems in the regions where migration begins and ends. Research questions and approaches are frequently designed along the lines of national traditions and patterns of state reactions towards international migration and its societal effects. Seen in this way, migration research seems itself to be rather a part of the complex of problems that it claims to describe and explain. This context dependency certainly becomes more visible in international research projects, since here researchers are more often compelled to explicate their preconceptions.

Systematically, this leads to a number of questions: To what extent and how is migration research shaped by 'national paradigms' or 'hidden national agendas' like 'race relations' in the UK, 'ethnic minority policies' in the Netherlands, 'assimilation into a French citizenry' in France or 'integration into a welfare state' in Germany? These paradigms are perhaps even present in critical efforts of scholars who strive to overcome their 
very boundaries. ${ }^{2}$ How do these national patterns influence the way in which international research and scientific modes conceptualise their research questions? What are the consequences of this for the claim of scientific validity with regard to propositions and applied theories? These questions have hardly been addressed systematically in migration studies (Lavenex 2005; Vasta and Vasoo 2006) yet their investigation is an essential precondition for adequately reflexive international research.

The assumption that research may be imbued with 'national paradigms' is intentionally constructed in a paradoxical manner. Put in this way, we focus on one characteristic of the field of research, i.e. the indexing of the paradigms of migration research as 'national'. This may refer, on the one hand, to a quite unproblematic matter of fact: Migration research takes on different national shapes, since migration and the resulting societal constellations differ in each country. As a consequence, different research questions need to be asked, and correspondingly, different theories and methodological approaches need to be applied. Seen in this way, the heterogeneous appearance of migration research and concomitant problems of mutual understanding may be simply the result of a lack of sufficient joint explication and translation of approaches as well as their implicit context dependency. This would, however, not principally foreclose scientific claims of generalisability made by propositions on the basis of theories and methodologies applied in nationally confined migration research. It seems that the apparent paradox can be rectified easily and that it concerns a rather unproblematic case: Internationalisation of research would simply imply that nationally established approaches in migration research become more explicit about their generalisability claims and enable a process in which these claims are tested in an extended context of research, involving comparative research designs and competition among alternative scientific approaches. This will certainly be linked with the failure of research approaches and theories, i.e. we would just observe the normal and unspectacular course of science not really worth specific mentioning.

However, we approach the issue of 'national research paradigms' inspired by a more far-ranging assumption: The paradigms of migration research are 'national paradigms' not just because of their context dependency and insufficient clarification of the conditions of generalisability; they are 'national' because the modes of presenting problems and questions are politically constituted by the nation states for which migration becomes a problem or a challenge. This assumption finds initial evidence in the fact that migration research is usually perceived as part of the applied social sciences: This type of research emerged as a response to 'social problems' with the claim of contributing to their solution. This holds true for early American sociology, whose first chair was established in Chicago at the end of the nineteenth century, linked with the political expectation that it would generate useful practical knowledge able to contribute to the 
practical solution of those social problems stemming from immigration. ${ }^{3}$ This similarly applies to Australia (Vasta 2006) and to migration research in different European countries since the Second World War (Vuddamalay and Withol de Wenden 2006; Scholten 2007; Favell 2001; 2005; Boswell 2009). These practical conditions during the emergence of migration research do not necessarily prove that its different traditions create 'national paradigms' in the political sense introduced above, since no initial condition determines the structure of research programmes.

We take this point only as a first indicator for the validity of our assumption, and it turns out that it is easy to find others: 1) Up to the present, migration researchers tend to be rather 'committed' and less 'distanced' researchers. ${ }^{4}$ In many countries, they play a major role in conceptualising migration and integration policies, either directly or as government advisors. Much research is embedded in such activities, and 'policy relevance' is seen as an important criterion for migration research. 2) During the last decades, migration research has gained prominence in the relevant disciplines ${ }^{5}$, although it did not contribute significantly to the theoretical or methodological progress of these disciplines. Central and paradigmatically relevant theoretical and methodological debates in the various disciplines have influenced migration research only to a minor extent and vice versa: the findings of migration research had and still have a rather low impact on these (sub-) disciplines. The general (political) consensus about the societal relevance of international migration - linked with the willingness to provide more resources for research - has created a climate of reputation and recognition for migration research, which is not substantiated by scientific achievement. Research may be confronted with increasing expectations, but the research questions and answers as well as research approaches remain largely the same - certainly permitting differences in scientific preferences mainly dependent on the orientations of the researchers.

Against this backdrop, we suspect that the paradigms of migration research are national in the sense that they are hybrids resulting from the handling and redesign of politically constituted problems by means of scientific research. We want to clarify if and to what extent the tension between the national constitution of the migration problem and its scientific treatment affects the scientific claim of universality. Do aspects external to science penetrate the internal conceptualisation of problems, theory building and research design in migration research in a way that leads to the emergence of 'national paradigms' of migration research?

In order to answer these questions, we need to clarify first to what extent the problem of migration is constituted by the organisational form of the nation state, and how different nation states frame the specific modes of raising problems, which in turn define the subject of research (I). Second, we discuss how the relation between practical relevance and scientific 
claim, between 'commitment and distance' (Elias 1956), is moderated in migration research, and what kind of 'national paradigms' emerge out of this process. The challenge is to identify the relation between politics/policies and science in different traditions of migration research. We assume that in each case a specific relation of mutual enablement and restriction provides the ground for different national paradigms (II). Finally, we discuss to what extent these paradigms and their foundations remain relevant for the more and more internationally and comparatively oriented migration research.

\section{Nation States as Constitutive Frame for the Problem of International Migration}

In all nation states, international migration and migrants become periodically a political issue, yet in varying ways and with a focus on different topics. Therefore, an analytical framework of analysis is required that allows us to account for commonalities and differences between nation states in dealing with international migration (1). Based on this framework, we provide some arguments for the assumption that nation states conceptualise international migration based on their structural constitution (2). In a third step, we discuss the extent to which these conceptualisations are mirrored in the different national traditions of migration research (3).

1

Migration is usually defined as the movement across borders, from one nation state to another - or from one society to another (Treibel 1990, 21). In contrast, internal migration is evidently considered as normal, unproblematic or even functional and necessary, strengthening national cohesion and opening access to locations where people can work and live most effectively and satisfyingly - the practical realisation of Adam Smith's idea of the invisible hand. In other words, internal migration in national labour markets is not only seen as normal, it also refers to the socially institutionalised expectation of social mobility. Internal migrants are therefore neither perceived nor treated as migrants. Instead, the emergence of conflicts about internal migrations usually indicates that a nation state is in crisis, that processes of political erosion articulate themselves in increasing desires to split up and create new states - be it a most imaginative 'Padania' in the north of Italy, an independent Assam in the northeast of India, an independent Kurdistan cutting across Turkey, Syria and Iran, or a Kosovo free of Serbian domination.

The field of migration research dealing with international migration is therefore over-determined by a contradiction, which has been prominently labelled 'the liberal paradox' (Hollifield 1996): One central assumption of 
liberalism is that the freedom of movement of people as well as of goods, capital and services refers not only to a natural right but also provides the basis for the smooth operation of society. Restrictions upon such freedoms are associated with authoritarian governments - pre-modern, colonial, fascist or communist - and are seen as dysfunctional for a modern, i.e. open, economy. On the other hand, national sovereignty, including the right to control access to state territory, remains largely unquestioned. This is taken as a basic principle of international and national law, only slightly modified by the non-refoulement clause of the Geneva Convention. Communitarian philosophers have reaffirmed this position as a legitimate right of closure, based on the operational mode of communities and the requirements for societal cohesion (Taylor 1993; Walzer 1983; 1990).

Only a small minority of political theorists takes a principled stance against the territorial sovereignty of states (Bauböck 1994). On the whole, however, idealist hopes for a borderless world (Soysal 1994; Jacobson 1996) have faded away since the fall of the Berlin wall. Inside the European Union, the liberal paradox seems to be solved: The freedom of movement is largely institutionalised, and despite the recurrent fears accompanying each enlargement round, no serious social tensions have arisen so far. The liberal paradox re-emerges, however, at the external frontier of the EU, and new member states situated at this border have to prove their maturity for full membership by implementing Schengen conditions and by establishing border control capacities according to EU standards.

In more general terms, 'the liberal paradox' refers to a structural contradiction of modern world society: On the one hand, international migration is an outcome of the social expectation involved in the institutionalised form of mobility in modern world society, i.e. individuals are expected to move where relevant social chances for participation and resources for an autonomous life are available. International migration means precisely the effort to realise opportunities for a living by means of geographical mobility. This does not per se imply structural problems for the primarily affected social systems, like labour markets, education systems or families the freedom to move may be rather a precondition for their functioning, as liberals argue. ${ }^{6}$ Nevertheless, most international migrations are, on the other hand, confronted with all kinds of legal and political interventions and restrictions.

The structural basis for these regular interventions is the organisational form of politics in modern society, i.e. the nation state. Political and legal interventions in international migration occur regularly and not just by historical chance. They make manifest the internal structural contradiction of world society (Stichweh 1998), i.e. the permanent production of motives for international migration - due mainly to the demand of labour markets and the opportunities of educational systems, the institutionalisation of the nuclear family, the worldwide communication of options by the mass 
media and the accessibility of transport (just to name the most important factors) - and the constant political effort to control these migrations ${ }^{7}$ and to mould motives for migration, according to the specific structure of the political system, i.e. its internal segmentary differentiation into nation states.

One strong implication of the worldwide institutionalisation of national states has been the partitioning of the world population into state populations (Halfmann 2005). International migrations have always challenged this division by crossing borders in the quest for chances of social participation. The reactions of nation states towards these migrations are mediated by the two constitutive dimensions that define the relation between states and their populations: a) the dimension of loyalty refers to the requirement that citizens and all other persons residing in a nation state territory show obedience and participate in political decisions; it is therefore a fundamental condition for the reproduction of state sovereignty; b) the dimension of provision refers to the obligation of the state to provide legal, political and social security in exchange for loyalty coagulating in the concept of the welfare state (Marshall 1950). ${ }^{8}$ Nearly all political modes of regulating international migration are geared towards aspects linked to one or both of these dimensions - loyalty and provision (Bommes 1999). ${ }^{9}$ These two dimensions are deeply interlinked. States shape their take on migration on the ground of patterns based on the conceptualisation of the population as citizens resulting from historical state building processes: How the population is constituted as a national community of citizens and the related design of the welfare state define the common ground for all kinds of political reactions to be found in states dealing with migration. They are, however, differently articulated due to the different course of state building based on different dynamics in the emergence of the state population and the building up of welfare systems.

One major difference between European nation states and the traditional immigration countries (USA, Canada, Australia) has always been the building process of state populations and the related concept of loyalty: European state populations are the historical outcome of the efforts of emerging states to establish sovereignty over a territory and a people against competing claims of neighbouring states (Tilly 1990). Nation building in Europe took place as a process by which a population was delineated and transformed into a nation, a people within a politically defined territory (Koselleck 1992). This outlines the historical background for the varying concepts and meanings of civic community as 'the people' (Brubaker 1992) and the specific relevance of the loyalty dimension in dealing with migrants in Europe (Bade 2003). In contrast, in traditional immigration countries immigration has been an integral part of the population building process by conceptualising immigrants, in principle, as future 
citizens - despite the exclusion of certain migrants for a long time on racist grounds.

The different histories of state building also provide the background for the different meaning of the welfare dimension in Europe and in traditional immigration countries in dealing with migration. The emerging modern states in Europe sought to politically mediate the chances of inclusion and exclusion in reaction to the breakdown of pre-modern stratified orders of inclusion (Bommes 1999). The modern nation state can most generally be defined by its successful claim of sovereignty over a territory and a population. From the outset, this was linked to the emergence of the welfare state (Swaan 1988). By providing chances for participation in the social realms of the economy, law, health or education - that is within a welfare state - the nation state created the social preconditions for a process in which former subjects were transformed into political citizens. This was a process in which the inclusion of the whole population into the political system via the individual citizens and the claim of political sovereignty over them could gain political legitimacy and universal validity. The welfare state became the central authority in modern society moderating relations between the principle of universal access ${ }^{10}$ to and inclusion in the social realms of the economy, law, education, health or politics and the empirical reality of social exclusion.

The effect was that national welfare states became the institutionalised organisational model of the political system in world society, and they have evolved as international 'thresholds of inequality' (Stichweh 1998). This means that they have guaranteed the internal loyalty of their citizens by a welfare policy that promotes chances for inclusion based on external closure and exclusion. From its beginning, welfare provided by nation states had a territorial index. The provisions of welfare states initially addressed primarily citizens, i.e. those individuals perceived by states as belonging to their territory. The nation may have been defined in either cultural (e.g., Germany) or republican terms (e.g., France), but in the historical context of competitive state building processes in Europe, the common welfare of the people of the nation - of the community of national citizens - evolved as the general frame of reference for states (Bommes 1999). This involved the political claim for not only formal, but also some substantial equality for all members of the national community; a claim based on the political form of membership, i.e. citizenship (Marshall 1950).

This European model of the national welfare state gained worldwide relevance (Meyer et al. 1997), ${ }^{11}$ although in different ways. Again, for our purpose, one major difference between European welfare states and the traditional immigration countries is telling: Welfare in Europe implies a more or less thick notion of 'the people' as the original political collective that defines the addressee of welfare; correspondingly, migrants are seen as potentially illegitimate welfare seekers from outside. In contrast, immigration 
countries conceptualise and recruit immigrants traditionally as potential contributors to welfare - not because these countries do not provide welfare in a privileging manner, addressing primarily citizens, but because immigrants are right from the start expected to become future citizens. In other words, the production of welfare has always been based on immigration, whereas welfare in Europe is still to a large extent perceived as a '(gross) national product' leaving the contribution of outsiders, i.e. migrants, with only limited acknowledgement. ${ }^{12}$

Despite these differences, in a most general sense, all national welfare states try to privilege their citizens (or what they consider to be their core citizens). They try

- to open or facilitate access to the relevant social systems (the economy, law, education, family or health) and to reduce the risks of exclusion;

- to stabilise these systems and their capacities of inclusion (labour markets, families, education, health, etc.);

- to equip individuals so that they fulfil the conditions for social participation;

- to compensate for the social consequences of failing access.

In order to achieve these objectives, states rely fundamentally on law as a means of assigning rights and duties, of the political distribution and redistribution of funds and the symbolic communication of civic duties. These state efforts lead to highly differentiated welfare infrastructures encompassing social security systems, which deal with the modern core risks of accident, health, age and unemployment, with social benefits for families, programmes to increase access to education, social benefit payments for the long-term excluded and poor, various public provisions of social services, etc.

National welfare states differ tremendously, even in Europe, and it seems that this will also remain the case in the near future, despite the advancement of globalisation and European integration and some, although limited, processes of model mixing and assimilation (Obinger et al. 2006). These differences are a result of the varied histories of national state building. Welfare structures are the outcome of the accumulated political decisions in history; they mould welfare in nationally specific ways with regard to concepts of social cohesion, the size and qualities of a constituency, legitimate membership and access to rights as well as notions of social risks and failure, and expectations of mutual obligations constituted by solidarity, which define we-collectives of insiders and complementary outsiders. Different welfare states represent therefore different welfare cultures, i.e. bundles of organisations, regulations and institutions referred to as welfare states are culturally deeply imbued. Conceptions of security and insecurity, assumptions about responsibilities for the provision of welfare, the limits of welfare and the extent of individual self-responsibility are contingent 
and not self-evident. There are always alternative ways, and it is certainly - at least in principle - possible to organise welfare differently. Each welfare state is based on different assumptions about what states should do, and to what extent they should intervene, about the meaning and foundations of freedom or solidarity, about the main institutions and foundations of society, etc. ${ }^{13}$

2

These considerations on the relation of national welfare states and international migration provide an adequately generalised model in order to account for the different modes in which international, i.e. trans-border, migrations are conceptualised as political issues and handled by states. By adequately generalised, we mean that this model should allow further casedependent respecifications, e.g. to account for differences between large and small welfare states, the formation problems of new nations in Asia and Africa, the transition of countries, like Turkey, from traditional emigration countries to transit and immigration countries. We assume that these political modes of conceptualising migration resurface in the paradigms of migration research, mirroring country specific constellations. In the following, we summarise the assumptions of this model:

A commonality of different states is defined by the need to solve a bundle of problems, in order to build and maintain a capacity for the production of collectively binding decisions. Essentially, this includes the enforcement of the claim of sovereignty over a territory and its population, i.e. the people. This implies, as elaborated above, the two dimensions of loyalty and provision: What kind of loyalty is expected from whom, and who is suspected to be disloyal (e.g. autochthonous minorities, migrants coming from competing neighbouring states)? Who should be included in civil, political and social provisions, and who should be excluded? What kind of civil, political and social provisions are institutionalised, and how are they related to internal historical conflict constellations and cleavages? Dependent on the historical handling of these constellations by states, international migrants denote groups that stand in many respects in stark contrast to the different demarcations and delineations resulting from state building processes:

A. The relation between international migrants and the group of citizens is precarious. Dependent on how delineations are defined, the conditions for the inclusion of migrants are more or less open or restrictive, linked with expectations concerning cultural similarity, the willingness of acculturation, assimilation and loyalty. These expectations are anchored in notions of the hereditary or acquirable character of cultural patterns, paradigmatically articulated in the opposition of republican and ethnic concepts of citizenship. ${ }^{14}$ These distinctions prove to be relevant not only in Europe, but also for migrations in the successor states of the 
Soviet empire or the postcolonial states of the former Third World. Additional complications face those postcolonial migrants in Europe for whom national citizenships had been open (like in Great Britain, the Netherlands, France and more recently in Spain and Portugal). After closure, however, their social position has been redefined in most of these countries in terms of ethnic or race relations.

B. Notions of (potential) belonging organise not only the formal rules of access to welfare provision, which may include or exclude different migrants to a different extent, but also the social perceptions of the legitimacy to claim benefits and the chance to scandalise it publicly.

C. In different national welfare states, migrants acquire differentiated access to social rights and provisions. This depends on the different mode of construction of welfare states; and fairly often, it is removed from the question of whether this access is politically perceived as legitimate: It can be the long-term outcome of participation in the labour market of welfare states which make access to social rights dependent on employment; it can be the effect of welfare provisions that address the legally resident population living in the state territory.

D. Migrations become a political issue in different ways depending on the internal order and infrastructure of states: in countries with majority voting systems differently from countries with systems of proportional representation; in centralistic systems differently from federalist systems; in democracies differently from dictatorships, etc. That is to say, the forms and dynamics of the reproduction of state power are relevant for the question of if and how migrants become an issue under the perspectives of loyalty and provision.

If one regards this approach as an underlying framework of reference, one can immediately notice that international migration and migrants assume the form of specific problems in different countries, which depend on the design of these states, their internal way of reproducing sovereignty, and the related conceptualisation of loyalty and power relations. This explains the difference between immigration countries and those countries in Europe that conceive of their form of political organisation by dint of founding myths as the constitution of native populations on ancestral territory. We have already discussed that this leads in each case to different conceptualisations of migrants in their relation to the state population as well as to welfare.

Nevertheless, the 'multiculturalisms' of the immigration countries Canada, USA and Australia differ substantially from one another: In Canada, multiculturalism has served since the 1960s as a sort of moderator for the latent tensions between the two founding nations, while at the same time it commits immigrants to this constellation. In Australia, it can be traced back to a changed international situation in which the country 
repositioned itself politically in the Pacific region under the motto 'populate or perish', by opening itself to immigration from Asia since the late 1960s. Australia linked this development with a 're-description' of its state population. As in the United States, this was accompanied by recurring fears, whether on the basis of plural origins living together harmoniously, immigrants can turn into loyal citizens or, vice versa, whether the foundation of the state, a certain degree of uniformity and coherence among its inhabitants, is at risk. On the basis of the highly selective admission of immigrants, these countries also differ with regard to the access immigrants have to welfare benefits. However, especially their selectivity reduces the likelihood that such benefits are claimed. It is, therefore, hardly accidental that, particularly in the US, public debates arise regularly on the issue of the exclusion from such benefits - yet, these concern in particular illegal immigrants before the backdrop of an economic situation in which the extended employment of such immigrants in certain sectors of the labour market and the continued demand for them are hardly hot topics. This leads to hypocrisy in public scandalisation and the establishing of harsh control and defence apparatus, in particular along the border with Mexico, while the immigration and employment of such migrants continue (Cornelius et al. 2009).

In Europe, despite processes of adjustment during the last 15 years, differences between the states remain, be it between cultural and political concepts of nations (Kulturnation vs. Staatsnation), between republican and multicultural-pluralistically oriented policies, or with regard to the constitution of their welfare states. This finds expression in the conceptualisations of migrants in relation to state populations and in the variations of what, unlike in the United States, is in most European countries purposefully taken as the 'integration' and not as the 'assimilation problem' of migrants. In France, for instance, republicanism turns out to be a quasi-lens through which all immigrant-related issues are seen, be it the issue of access to citizenship, which as a matter of course is open to migrants conceived as immigrants based on the recognition of the republican order and the assimilatively oriented expectation to become French, the shaping of the inclusion of migrants in the educational system, or the handling of cultural and religious pluralisation. This has the mirror effect that immigrants perceive their actual social marginalisation as withholding the republican promise to be part of the French nation.

In the Netherlands the conceptualisation of immigrants as ethnic minorities was, since the 1970s, based on the pillar model anchored in the specific Dutch state building. Until the 1990s, the corresponding direction of welfare state integration policies allowed the combining of post-colonial immigration and recruited labour migration in a historically proven model. The resulting tension between political, multicultural tolerance and the de facto marginalisation of large sections of the immigrant population in the 
labour market and in cities under well-developed welfare-state conditions initiated the continuous and increasingly restrictive transformation of migration and integration policies, associated with both increasingly aggressive, publicly expressed expectations of migrants to assimilate and considerable turbulence in the political party system. In Denmark, immigration and its consequences run counter to the country's self-image as a culturally and socially completely homogeneous nation.

In the British case, the conceptualisation of the immigration issue as 'race relations' shapes the public debate, which has its basis in the immigration of 'former subjects' of the British Crown from the 1950s to the 1970s. Migration and opportunities for social participation of migrants are primarily conceptualised as problems of the equitable cohabitation of 'races', of multicultural tolerance and anti-discrimination, which are meant to domestically signal acceptance and equality towards immigrants, given the closure of the British state for their home countries and for former subjects of the Commonwealth in general. Historically rooted in the history of the Empire, this conceptualisation is currently being 'overwritten' by a new wave of immigration after the EU enlargement. According to the priorities of New Labour, it is being replaced by a new interest in 'indicators of social integration' regarding immigrants from Eastern Europe, also in view of the increasingly apparent limits of the absorption capacity of the 'open labour market'.

The conceptualisation of migration and migrants in Germany, which has experienced several immigrations encompassing refugees and expellees, 'guest workers', asylum seekers, civil war refugees and ethnic Germans (Aussiedler) was determined by two reference frames: a) Germany is not an immigration country (Einwanderungsland), and therefore immigrants (Zuwanderer) are not automatically seen as immigrants (Einwanderer); they can and should become Germans only under restrictive conditions; b) permanent immigration (Zuwanderung) $)^{15}$ and the settlement of migrants refer to problems of social integration, which are the responsibility of the welfare state. Into the $1990 \mathrm{~s}$, an ethnically founded citizenship barred access to the naturalisation of migrants. Since then, under certain conditions concerning integration, citizenship has become obtainable. On the other hand, since the Second World War, the positive reference to what constitutes a German was eclipsed and cultural difference was primarily conceptualised as a problem for social integration, as a deficit and hurdle for the required adaptation, particularly in education and the labour market. This perspective remains prevalent until the present day and now also includes ethnic Germans (Aussiedler) after their reconceptualisation from formerly cultural Germans to culturally and socially different migrants with typical integration problems. On the other hand, the German welfare state proved to be inclusive in the sense that it effectively provided protection not only for large parts of the migrant workers of the 1960s and 1970s due 
to compulsory social insurance, but it also covers the basic needs (food, clothing, accommodation, health) of all individuals residing in its territory via the welfare state concept. To a limited extent, this also applies to asylum seekers. In Germany, the problem conceptualisation of migration and migrants revolves, therefore, mainly around the question of whether immigrants can provide for themselves and whether they receive social benefits legitimately - in other words, whether in the long run they manage their 'social integration' successfully. This finds its most recent expression in the fact that probably in no other country in Europe was a 'national integration plan' created with a comparable symbolic effort.

Moreover, the management of immigration by the Mediterranean countries in Europe is embedded in their specific state traditions. The Italian case indicates that the political handling of the significant immigration since the late 1980s, rooted in the demands of an EU increasingly organised in regard to migration questions, can only be explained in the context of a growing demand for services of a familistic welfare state faced with the demographically accelerated ageing process of its population and a tradition of the legal rectification of illegal situations, be it in relation to the building code or residence permits. In this way, as in Spain, illegal migration and its legalisation became de facto migration policy, against the actual backdrop of an official EU-oriented policy.

Discussions about the way in which states conceptualise problems associated with international migration are usually confined to traditional immigration countries and Europe. A look at worldwide migration (Castles and Miller 2009; Massey et al. 1998; Thränhardt and Hunger 2003) shows quickly, however, that the political handling of international migration is also anchored in the structures of statehood in the respective countries and regions. As the contributions on Nigeria and Malaysia in this volume show, both countries debate 'social cohesion', the definition of a constituency, of the people constituting the nation, of its delimitation and the claim and testing of the reach of state sovereignty with regard to migrants, who are partly, even by dint of violence, excluded from rights and benefits and expelled from state territory. ${ }^{16}$

Public policy regarding international migration and migrants was and is embedded in international discourses. One can characterise the late nineteenth and the first half of the twentieth century as the era of the prevalence of the nation state. This era is also associated with unquestioned domestic assimilation policies of countries towards their minorities and immigrants as well as related policies, such as the one set forward by the League of Nations, which reacted to the vulnerability of this policy, apparent in forced cultural homogenisation, separatist tendencies and wars, with the redesign of state borders based on the 'right of self-determination of peoples' or with the resettlement of ethnic minorities, be it 'voluntarily', as in the case of the Greeks and Turks in the Treaty of Lausanne, or coerced, 
as in the case of the Allied Potsdam Agreement with regard to the Germans in Eastern Europe.

The period since the Second World War was characterised by a decline of nationalism in Western countries, the dominance of liberalism and the increasing differentiation between law and politics as well as decolonisation in the Third World. This was associated with a relative decoupling of state, nation and culture. Since then, cultural differences are seen as legitimate, cultures are considered equal, and cultural pluralism is now regarded as beneficial. An early source is the UNESCO Declaration on the equality of cultures, which emphasised the right to diversity and its value. This has not necessarily been replaced but, rather, has been accompanied by a 'return of assimilation' (Brubaker 2001) in discourse and political expectations in many countries, which does not necessarily constitute a negation of the UNESCO Declaration but, in different ways in different countries, calls into question the benefits and value of cultural pluralism. The need to clarify the relationship between cultural pluralism and the indispensable conditions for participation in the functional systems of education, the economy, law, health, religion, and the mass media is also brought into focus, such as the tension between human rights, cultural pluralism and relativism, respectively.

International discursive formations impact differently on the political public as well as on policies of individual countries; they are re-articulated against the backdrop of respective national histories. Multiculturalism, concepts of diversity, integration and assimilation denote different things in each case and can therefore not be understood adequately in isolation from their contextual embedding.

3

International migration and its associated problems are, as shown, substantially constituted by the character of policy and the specific structure of states. They form the filter for international migration, which is essentially caused by the mobility in modern society and thereby lend it a specific shape as a problem. The latter is reflected in the ways of conceptualisation in the various strands of national migration research.

Even a cursory comparative glance shows that the outline in the previous section of individual aspects of concepts of international migration as problems in various countries finds its reflection in the main issues of national migration research, which shall be briefly illustrated in the following.

West German migration research formed itself by means of state-constituted migrant groups. At first, it succeeded as research into refugees and expellees, then as research into guest workers, foreigners and ethnic Germans (Aussiedler), before it developed into general migration research. At the centre of its research stands the question of social integration, and 
the latter, in its different ways of conceptualisation since the 1970s, is evidently geared towards the guiding precepts of the West German welfare state, its guest worker foreigner policy and later policy concerning ethnic Germans as well as, finally, its current immigration and integration policy.

The issues of French migration research revolve around republicanism and related questions: Which consequences do international migration and the settlement of migrants have, especially for the associated expectations and concepts of assimilation, citizenship and laïcité; whether immigration is inevitably associated with the growing importance of cultural, ethnic and religious differences; whether their public irrelevance should be maintained or instead be replaced with forms of tiered recognition; and finally, the questions of whether such differences can be empirically recorded and whether their relation to other social dynamics within families, on labour and housing markets, or in the school system ought to be and shall be explored.

In the United Kingdom, 'race relations' are the constitutive reference point for British research on migration until well into the 1990s. The critics of this approach distance themselves by marking this approach as 'racist' (Miles 1994) in a tu quoque mode and thus remain performatively tied to the criticised frame of reference in a peculiar way. This constellation, based on the immigrations of the 1950s to 1970 s in the context of a disintegrating commonwealth, is being increasingly replaced by more recent research, which essentially follows the objectives of New Labour, highlights the potential and benefits migration brings, and explores 'indicators of integration'. ${ }^{17}$

Migration research in the United States is often characterised by the old question of assimilation, starting with Thomas and Znaniecki, Park and Gordon, and ranging from Gans, Portes \& Rumbault, to Alba \& Nee and Waldinger. It places at its centre the constitutive problem of the United States - how social order and coexistence can be guaranteed on the basis of the coming together of so many different nations/regions (e pluribus unum). This continuation finds its plausibility in the huge waves of immigration since the civil rights reforms in the mid-1960s, which currently keeps timely the question of whether the 'melting pot' still works. Noted processes of differentiation are characteristically discussed as 'segmented assimilation'.

In Australia, migration research and its concepts were not only shaped by the multicultural orientation of immigration policy since the 1970 s, the latter has also significantly helped to develop this policy - not least because of its close organisational link to politics.

Especially the last example shows that the orientation of different national migration research towards the ways in which different states conceptualised international migration, immigration and settlement as political problems did not hinder the production of solid empirical and theoretical contributions. However, a reflection from a sociology of knowledge 
perspective of this conceptually narrow focus and the often organisationally close links between science and politics in the field of migration research is still lacking.

\section{National Paradigms of Migration Research? The Relationship of Politics and Science in Migration Research}

The aim of the following considerations is to develop a framework for such a reflection. The contributions of this volume provide material, to some extent, with which to begin such a project in a comparative perspective. Upon closer inspection, the determination of what could constitute national paradigms of migration research creates, conceptually, more difficulties than the charm of this initially attractive project suggests.

$A$ In the previous sections, we have highlighted how deeply migration research is imbued by its embeddedness in the respective nation states. This does not overlook the fact that migration researchers have in turn a significant influence on the shaping of migration policies and related problem conceptualisations in many countries. The permeation of migration research by politics and statehood is therefore not based on a relationship of instruction. The issue is rather the interplay between the two on the basis - usually, at least - of mutual independence. We assume that this independence constitutes their interdependence: ${ }^{18}$ Politics cannot produce scientific, i.e. research-legitimated, knowledge and science, vice versa, has no access to political power and collectively binding decision-making, ${ }^{19}$ but for central functional conditions - particularly the freedom of science and access to resources - it remains dependent on law and its political enforcement as well as to a significant extent on resources made available politically. This captures the relationship between science and politics in very general terms, yet the issue here is how they are shaped in and impact on the relationship between migration research and politics.

$B$ Migration research does not match the internal differentiation of science into disciplines, and this justifies the assumption that it is research with an essentially interdisciplinary orientation (Brettell and Hollifield 2000; Bommes and Morawska 2005). In the political and academic discourse, interdisciplinarity is, much like internationality, seen as an indicator of quality, but initially, it primarily constitutes a problem. Migration outlines a field that involves many disciplines and calls for their responsibility: sociology, psychology, economics, political science, pedagogy or law, social geography, ethnology and medicine. This characteristic transverse position of migration as a topic repeats itself within the individual disciplines, as can be easily shown with regard to sociology. Here, migration research operates as a reference point for sub-disciplinary specialisation, on the one hand, and accordingly there exists a nationally and internationally 
organised sociological migration research.

On the other hand, according to an established textbook, sociological migration research deals with migration as the "permanent or increasingly permanent move into another society or into another region by an individual or multiple persons' and 'with the causes, course and consequences of migration' (Treibel 1990, 21). It can therefore hardly avoid dealing with almost all fields with which sociology is also concerned in its various subdisciplines. 'Causes' refer to the initial socio-structural contexts of migration, which require migration sociologists to have substantial knowledge of developmental and migration sociology as well as anthropology, in order to produce scientifically adequate descriptions. The 'consequences' of migration consist in the fact that migrants often appear in all relevant social contexts, i.e. the economy, politics, law, education, health, sports, mass media, or religion of the target region, either individually or as families. Therefore, migration sociologists also have to assume roles as family sociologists, educational sociologists, youth or legal sociologists, labour market researchers, business, industry or organisational sociologists, inequality researchers, conflict sociologists, political scientists or political theorists and so forth. ${ }^{20}$ This is almost inevitable, as migrants, like all other individuals, occur in society and its differentiated social structures. They become relevant to political, legal, economic, educational, health or religious issues, or as members of organisations. The manner in which they appear here makes them first visible as migrants.

This leads to the problem of generating a framework of reference for research that tends to repeat every specialisation of the discipline and that can therefore determine its identity only in terms of its difference from these specialisations. In a variety of fields, it therefore continually runs the risk of structural amateurism. This constellation recurs for migration research in a similar manner in other disciplines, such as law, political science (Freeman 2005) or linguistics (Maas 2007).

Consequently, migration research does not constitute a discipline, but refers to a multi- and interdisciplinary conglomeration of research which deals with issues of international migration coming from different disciplines. Hitherto, it is unlikely, yet not impossible, that it will evolve into a discipline, if disciplines are understood in a preliminary way as 'forms of institutionalisation of processes of cognitive differentiation' (Stichweh 1979), including the following elements: 1) a nexus of communication between researchers, 2) a body of scientific knowledge coagulated in textbooks, which is codified, accepted and teachable in the discipline, 3) a common set of problems and questions, 4) a common set of research methods and theoretical frameworks, 5) a career structure and modes of socialising and recruiting young scholars. ${ }^{21}$ One can certainly discover elements of an internal differentiation and of the emergence of an (international) migration research field; yet, this issue does not have to find its final answer 
here. Especially, at the organisational level, the founding of research institutes and the establishing of research associations occur. Yet, there are hardly any indications for the formation of a discipline. For the international and interdisciplinary research on migration, it can be stated in rather general terms: 'Since there [...] is no theoretical integration of disciplines, this form of cooperation is forced to take place at a low theoretical level' (Luhmann 1990, 642). Instead, migration research primarily gains relevance among the differentiated disciplines. However, due to its transverse position among the disciplines and the resulting danger of structural amateurism in view of the specialisations in various sub-disciplines, as mentioned above, it is even more confronted with the problem of defining its constitutive problematique.

$C$ In section I, we argued that the problem of international migration has its foundation in the contradiction of world society (the simultaneous production of migration motives through its institutionalised form of mobilisation and its restraint through the shape of politics) that national migration research finds its respective issues here and that thereby it mirrors, more or less, the ways in which the respective states conceptualise their policy issues. Due to its peculiar intra- and transdisciplinary mismatch and the resulting problem of how to delimit those problems defining research, one has to presume that migration research orients itself towards state conceptualisations of migration for structural reasons, namely due to its freefloating nature - not only because the politically explosive nature of the topic guarantees attention and resources, but also because this way of conceptualising offers a moderator, who serves to hold together the rather indefinite and frayed problem field of migration research with reference to two main views: 'integration' and 'inequality'.

These have, strictly speaking, their foundation in the classical nation state problem of cohesion vs. corrosion (integration vs. disintegration), peace vs. conflict, in modern European terms: social cohesion vs. disintegration. This problematique is rooted in the historical way the modern nation state emerged and differentiated itself. The latter links its claim to have the sovereign right to enforce collectively binding decisions within its territory and for people residing there and constituting the state population with the self-description as an entity, the uppermost and controlling body of nationally conceived society. This claim is based on the argument that the nation state is the legitimate expression and bearer of the national will of the community, be it politically or ethnically constituted. From the perspective of the state, functionally differentiated society is a state-delimited context in need of integration, which finds unity and cohesion in the nation, visible despite globalisation in the 'national economy', in the national education system, or in the nationally constituted welfare systems. From the outset, cohesion and corrosion, integration and disintegration of society are rooted in the notion of the state as an entity, as the national bond of 
society. With this focus on the state, the claim of the 'rule of the people' permeates the community as the promise, however difficult to keep, to steer society. Against this background, loyalty and domestic peace are signs of the integration of society as a community, whereas disloyalty and conflict, vice versa, are signs of disintegration. From this perspective, states have historically viewed ethnic minorities as well as political opposition groups as potentially disloyal and conflictive - in Germany the Social Democrats were, as is well known, seen as an 'unpatriotic bunch (vaterlandslose Gesellen)' (Groh and Brandt 1992). And in Britain the diverging cultures of the emerging proletariat, on the one hand, and the bourgeoisie, on the other hand, caused Benjamin Disraeli in the nineteenth century to talk of 'two nations' before the backdrop of the social upheaval of the industrial revolution, begging the follow-up question of whether this indicates the disintegration of society or casts doubt on its integration.

Cohesion and corrosion, 'integration' and 'inequality' - the central issue of migration research captured in different terms rehearses this old problematique: the problems of differentiation and inequality, and the question of whether and how the poor or the lower classes come to terms with unequal living opportunities; which potential for conflict it entails and to what extent this is relevant for the integration of society? These questions address migrants and the consequences of their settlement, recurrently and especially in Europe, with its development into a world immigration region after the Second World War, their integration perceived as precarious. And the EU reformulates this problem in tandem with the expansion of its competence claims in terms of inclusion/exclusion and social cohesion.

The main precepts 'integration' and 'inequality' of migration research are therefore owed to the modern state, as the birth of 'society' in the modern social sciences has its roots in the spirit of the nation state (Tenbruck $1981 ; 1992)$. In a manner similar to hardly any other sub-discipline in the social sciences until the present, migration research breathes the original spirit of sociology and of social science as a science of crisis (Habermas 1981); it presents the problem of political order as the problem of cohesion, 'integration' and the threat of internal disintegration through 'differentiation' and 'inequality', paradigmatically formulated by Durkheim in the late nineteenth century in his question about the possibility of a 'conscience collective' in modern differentiated society. ${ }^{22}$

Here, for migration research, the respective terms used are not of importance: in the American context the problem of assimilation concerns the question of how assimilation can be successful and considers cultural and structural assimilation, i.e. the relatively identical socio-structural positioning and the individual and social conditions under which this can succeed, as a prerequisite for the development of unity, whose extent has to be established in each case. In the German context, the same debate revolves primarily around the concepts of integration and inequality. In the Anglo- 
Saxon context, racial equality, ascertainable through non-discrimination in labour and housing markets, education, health, law and politics, is meant to allow coexistence on the basis of unity in diversity; similar points apply to the various types of multicultural policy. Certain aspects of policy might favour an orientation towards unity as the demand for adjustment or alignment, instead of granting civil and social equality; in a republican context migrants may be confronted with this demand. On the other hand, their principled otherness, defining the state population by its confines, might lead to their expulsion.

In this perspective, terminologies, the ways of conceptualisation in the different states, and the associated migration research rearticulate the problem of 'migration and integration' in various ways, rooted in the various histories of nation building. This is the exact reason for the various ways of conceptualisation. Yet, on close inspection, the same kinds of problems recur, and research remains tied to its state-specifically articulated problems, even if it deals with very different areas. Whether it deals with families, education, health, work, politics, law, mass media, religion, or language, everything is seen in terms of integration and inequality, successful or failed assimilation, the successful or unsuccessful easing of 'race relations'.

$D$ Does it make sense to talk of 'paradigms of migration research', if they are, as argued here, rather scientific rearticulations of nation statespecific ways to constitute international migration-related problem constellations? To answer this question, we first need to define the meaning, which has until now been left open, of the term 'paradigm'. Aware of the elaborate discussion following the 'paradigmatic' investigation of Thomas Kuhn in The Structure of Scientific Revolutions (1970/1976), we generally assume that a paradigm can be recognised by the central distinctions used to determine the subject of scientific research and the accordingly applied theories. The empirical study of science is concerned with the question of how science establishes the very criteria it applies to successful research. In this context, in order to clarify what can be called a paradigm in the strict sense, Kuhn (1970) distinguishes in his postscript between scientific communities $^{23}$ and what constitutes a paradigm in the strict sense as a 'model', its productive basic distinctions as starting point and basis for the discovery, differentiation and development of problems. Paradigms describe, therefore, functioning problem/problem-solving constellations, which are unlimited in regard to the number of problems to be discovered yet productive, and at the same time, they allow one to turn them into common forms of describing a problem and solving it (Kuhn 1970, 189).

The emergence of such paradigms requires the differentiation of science. Kuhn speaks of the 'unparalleled insulation of mature scientific communities from the demands of the laity and of everyday life' (164). Scientists aim to cater to the expectations of the scientific system, and their primary 
audience consists of scientists. Here, Kuhn sees a significant difference between the 'mature' paradigm-governed natural sciences and the humanities and social sciences in the fact that scientists of these disciplines have to more or less familiarise themselves with the entire history of problems and problem solutions for the area they work in; they also face a wide range of competing paradigms, whose appropriateness they have to evaluate themselves from case to case. This leads to a much lamented paradigm pluralism in these disciplines with the respective scientific communities as 'camps'. This might also be the basis for the tendency of social science, recognised by Kuhn, toward the 'choice of a research problem - e.g., the effects of racial discrimination or the causes of the business cycle - chiefly in terms of the social importance of achieving a solution' (Kuhn 1970, 164; emphasis added, M.B.). Yet, this is far from compelling, and the mentioned pluralism does not exclude scientific introversion in these disciplines and their 'insulation [...] from the demands of the laity and of everyday life'. The question is rather, under which conditions these disciplines follow such tendencies, and what their subsequent consequences are.

$E$ The community of researchers on migration may certainly be considered a peculiar example for the case that the choice of research problems is recurrently justified 'chiefly in terms of the social importance of achieving a solution'. Migration researchers are also hardly reserved, when it comes to communicating preferred solutions. Their majority advocates the equality of migrants - be it as integration, reduction of barriers to assimilation, inclusion and avoidance of exclusion, incorporation, and so forth - and see this as a condition for the cohesiveness of society, of its integration. Hence, they still stand not only in the tradition of the social sciences as a science of crisis and maintain its original spirit in their close link to the state; they also do not aim for the 'insulation [...] from the demands of the laity and of everyday life', but rather continuously emphasise their respective relevance. This applies to the various booms of migration. In times in which migration attracts less attention, migration research follows its daily business, that is, it delves into the ramifications of migration and integration processes and warns of the possible negative consequences of reduced attention to the overlooked or insufficiently noted effects of failing integration, indicated by social inequality, social deviation, etc. ${ }^{24}$

However, if migration and integration draw attention, migration research is a sought-after science of crisis, as migration and integration then become synonymous with the politically communicated public perceptions of the crisis of cohesion of a society essentially conceived as a national one (Bade and Bommes 2004). The capability to political action is then demonstrated nationally and at the European level by, among other means, the funding of research - and this despite the fact that sufficient experience already exists: 'The politician who grants research money, founds new universities, establishes institutions can pride herself immediately, without 
having to wait, whether and what the results are' (Luhmann 1990, 639).

This leads to a peculiar state of migration research, which is not simply caused, as one can see now, by the fact that it is traditionally rather an applied science, because the term applied science - differently from fundamental research - refers to the relation of the provision of science ${ }^{25}$ to other non-scientific social fields. It points to the provision of scientifically valid and specifically required knowledge. ${ }^{26}$ This does however not question the fact that applied science remains embedded in fundamental research, it must not contradict it and does contribute more or less to it.

However, this applies at best to a limited extent to migration research. Instead, one must probably state - pointedly - that migration research is periodically 'taken in' by its subject and 'allows itself to be abused' by it, as due to its proximity to politics, there 'lies in-between' no 'sufficient alienation' with the 'headstrong ability to discriminate' of a genuine scientifically constituted theory (Luhmann 1990, 645). Inversely, this is illustrated by the fact that migration research claims in Euro-technocratic terms its 'policy relevance', in contrast to what constitutes a modern science and that it increases the 'social imposition' of its knowledge and answers political questions all too often: 'This is as it is, make it so' (634). The risk here is reflected in the fact that those using this knowledge turn away due to foreseeable frustration. Thus, the permanent effect of damage to the 'facade of the security of scientific knowledge' (641) increases in the case of the contact of science with other areas of society. This becomes visible in the recent intense public debate in Europe surrounding the question of whether the integration of immigrants has failed and whether migration research has failed to provide the necessary knowledge and, therefore, failed in its role as early warning system. ${ }^{27}$ Due to its claimed practical relevance, it can hardly refuse this task - and reinforces this point by the repeatedly heightened claim of its policy relevance.

$F$ Should we, therefore, drop the concept of paradigm for migration research and, hence, also the assumption of national paradigms in migration studies? This is not an inevitable consequence; rather, one has to ask what kind of science migration research is. On the one hand, one can certainly talk about a community of migration researchers in the Kuhnian sense, based on the criteria outlined above, and in recent years this applies more and more to the national and also to the international level - remember that this was exactly the starting point for the argument developed here. Furthermore, most migration research scientists are active in organisations of the scientific system, in universities and research institutes. Moreover, a consequence of the previously argued is that one can speak of paradigms of migration studies in the sense that they display integration and inequality as central, nation state-specifically rearticulated distinctions with which the subject of migration research and the theories it applies are delimited and defined. In addition, this paradigm was productive, as can easily be 
seen with regard to the scope and breadth of migration and integration research.

The discussion of the peculiarities of migration research and the pointed formulation that migration studies 'allows itself to be abused' by its subject matter, as due to its proximity to politics it develops no 'sufficient alienness' with a 'headstrong ability to discriminate' a genuine scientifically constituted theory, is essentially based on the assertion that migration research is not a case of a differentiated science in the sense introduced. To properly understand this fact, the Kuhnian distinction between mature and immature science is not of much help. Paradigm pluralism and competition do not exclude the differentiation of science, rather the latter requires the former. Therefore, this does not cover the claim that migration research is not a differentiated science.

Rather, we have suggested earlier that migration research solves the structural problem of its disciplinary and transdisciplinary transverse position with reference to the political constitution of the problems of international migration. In this way, it is and remains (from a systematic perspective), thus far a hidden reflexive theory of the political system by producing descriptions of migration studies in response to the self-descriptions of this system and its environment, here migration and its consequences, as its composition and not as a scientific outside description. ${ }^{28}$ The concepts of migration research are based on an understanding of the political system, which in reference to the latter's self-conception, the hypostasis of its function - to produce collectively binding decisions - the primacy of the 'integration of society' assigns it a kind of overall responsibility for society and, therefore, for the problems caused by international migration. ${ }^{29}$

This policy-centric concept of society is shared by migration research with everyday accounts, the mass media, protest movements, and with some of the other social sciences, not least political science. There are several reasons for this fact, which needs no further elaboration in our context. However, the difference to political science is revealing: The latter translates the tension between science and reflexive theory of the political system internally in the contrast between normative and descriptive approaches, externally in its difference to political sociology. However, in contrast, migration research turns out to be a quasi-unacknowledged reflexive theory of the political system, resulting from the handling of its disciplinary mismatch and the subsequent scientific exclusion and determination of its problems. The paradigms of migration research are national, as seen, because they constitutively gain their problems from the ways in which its respective reference state conceptualises international migration and its consequences. This similarity is the reason for its diversity, and with regard to these ways of conceptualisation it fleshes out its issues: the problems of integration and inequality in different areas of 'the society' and their need to be governed by politics. 
From this vantage point, one can also recognise why the systematic nature of migration research as hidden reflexive theory of the political system does not go away through its internationalisation - a notion which we can only touch upon here at the end. The insight that society can hardly be conceived of as national anymore does not need further detailed reasoning - strictly speaking, international comparative research still mostly denotes the comparison of national 'societies'. Transnationalism takes the criticism of the notion of society as a national container as its starting point, in order to continue to assume national societies (Bommes 2003b). All this aside, the continuation of migration research as a hidden reflexive theory of the political system seems, above all, to surface where it abandons the (exclusive) reference to the state as the organisational form of the political system. This becomes apparent in two currently important issues: In European migration research, the main themes of 'integration' and 'social cohesion' remain; $^{30}$ in the wake of the 'high-level dialogue' of the Global Commission, the increasingly important field of research on 'migration and development' tries to link problems of migration control with issues of integration, on the one hand, and conditions of a (failed) development policy on the other. Again, problems are here fleshed out in reference to the political system and its conceptualisations, oriented towards policy relevance and practical recommendations, whether they are consequences of the internal freedom of movement within the EU, the handling of illegal immigrants, or migration models as a 'triple-win' recommendation.

Due to the outlined reasons, an internationalising migration research should work diligently to ascertain the respective national paradigms, if only to dissolve the preliminary sketched 'I can't understand you' (Kannitverstan) situations in international research cooperation. In addition, it would suit it well to reflect its national histories as hidden reflexive theories of the political system, of its nation states, before it starts with enthusiasm to merely repeat old routines in a transformed manner at the international level.

\section{Notes}

I One exceptional example is the research funding of the EU. Within the Sixth Framework Programme, the Network of Excellence (IMISCOE) has been funded since 2004 (project period: 5 years). This network comprises over 20 established European research institutes.

2 Like in the work of Robert Miles (1993; 1994), who is clearly fascinated with the frame of race relations as he tries to move away from it.

3 In the introduction to their monumental work The Polish Peasant in Europe and America, Thomas and Znaniecki (1958) criticised this line of thought as an inadequate basis for scientific analysis as early as I9I8 (first publication I9I8). In principle, they see the migration and integration of Poles as a theoretically interesting case 
for the constitution of social order - but in substantial parts of the book, they fail to follow their own line of thought, i.e. to detach themselves from practical normative issues.

4 Following a concept by Norbert Elias (I956) which was taken up by Treibel (I988) for a sociological overview of the Ausländerforschung in Germany during the I970s and I980s; see also Bommes in this volume.

5 Especially sociology, political science, ethnology, history, geography, linguistics, education and economics. This multi- or interdisciplinary profile of migration research will be discussed in more detail below.

6 This is why geographical mobility within nation states, due to employment, family reunion or education, is socially not perceived as migration, and those involved are normally not treated as migrants.

7 See Castles and Miller (2009); the Global Commission on International Migration (GCIM) Report (http://www.gcim.org/en/finalreport.html) can be read as an effort to overcome this basic contradiction by means of temporalisation: arguing that international migration will be to the benefit of all 'in the long run' - being faced however at present with all kinds of 'short term' barriers.

8 Not all states become welfare states, since they are not able to build up the necessary capacity of provision. It is obvious, however, that no state can ignore the demands of its population to care for welfare, and so-called failing states can to a large extent not preserve the loyalty of their population because of their reduced or absent capacity to guarantee security and provision.

9 Current examples are the public association of migration and terrorism, which questioned the loyalty of migrants, on the one hand, and the frequent debates in nearly all European welfare states but also in the US concerning the effects of international migration on the capacity of welfare states in terms of costs and benefits, on the other hand (Bade and Bommes 2004).

Io Universalism of inclusion in modern society means that nobody should be excluded from claiming economic, legal or educational provisions, if he or she fulfils the social preconditions for these claims (Luhmann I989). For example, one can participate in education, if one is perceived as educable; one can participate in the economy, if one finds access to monetary means; one can participate in law, if one knows how to act on behalf of one's rights. At the same time, none of these necessarily imply that inclusion always succeeds empirically - on the contrary, it often fails. Yet the valid institutionalisation of social expectations, like the universalism of inclusion, provides the ground for the perception of this failure as a problem in need of remedy, e.g., by means of social policy.

II See footnote 9 .

I2 As an effect of demographic changes, European countries start to realise the extent to which they do rely on the attraction of immigrants. The recent debates on the integration of migrants articulate some of the fears linked with the realisation of the increasingly fictive character of nationally delimited perceptions.

I3 Different welfare states therefore make use of those institutions in different ways, i.e. individual freedom on markets (liberty and private welfare: liberal individualistic welfare states); families/communities (reproduction of the communitarian foundations of society: conservative corporatist welfare states); the state (social equality in labour market society; social democratic universalist welfare states). Based on those distinctions, it is possible to categorise welfare states into different types. According to Esping-Andersen (I990), we find three such types, i.e. the liberal, the conservative and the social democratic type of welfare state in Western society. Accordingly, welfare states differ with regard to their extent of de-commodification, i.e. the extent to which income and social security is made dependent on participation in the 
labour market; the role and amount of residual spending, i.e. national assistance as a percentage of social spending; their redistributive aims and capacity; their corporatist structure, i.e. the differentiation of social security systems according to different occupational and status groups; the amount of private spending for health and pension systems; their conceptual assumptions about the main provider of welfare, i.e. the market, the family or the state. Along these lines, welfare states vary largely according to their orientation, which can be distinguished as individualistic vs. corporatist vs. universalistic. Examples of the liberal individualistic type are the UK and the USA, for the conservative corporatist type Germany, Austria, Italy and France, and for the social democratic universalistic type the Scandinavian countries, especially Sweden and Denmark (Esping-Andersen I990; Schmid 2002; Opielka 2004). Many aspects of this modelling have been criticised. Some argue that there is a fourth type in Europe, the Mediterranean type (Ferrera 1998); some question the empirical applicability of the model (Alber 2000). For a discussion, see also Kaufmann (2004). During the last ten or fifteen years, there have also been extensive discussions about the adaptive capacity of these different welfare state types and their ability to cope with new constellations as a consequence of the challenges of globalisation (see Esping-Andersen 1996; 2002; Ganßmann and Haas I999; Goodin et al. I999; Alber 2000; Fligstein 2000; Kaufmann 2003; Leibfried and Zürn 2005); on a most general level, the outcome of this discussion is that those welfare states do best which manage to combine access to labour and the provision of welfare, instead of providing welfare as a substitute for labour - a problem mainly for the conservative corporatist type of welfare states. In many countries, the recent shift to so-called activating welfare policies is a reaction to these problems. Integration policies in many countries belong in this context. Typologies of welfare states have been developed in the context of international comparative welfare state research. Certainly, they are to a large extent based on the analyses of leading Western countries; see, however, Esping-Andersen (2002) for more comprehensive comparisons. New immigration countries like Malaysia (an ethnic welfare state), Nigeria (a corrupt state) and Hong Kong (a free market system) do not fit into these schemes.

I4 Often but misleadingly explicated by the difference between the French and the pre2000 German concepts of citizenship (see Hagedorn 200I and Gosewinkel 2003).

I5 Migrants who enter the country are not automatically perceived as continuous immigrants. So the question of whether they want to remain as immigrants is kept open by the expression Zuwanderer whereas the expression Einwanderer in German means that the migrant is expected to stay in the country. Choosing the word Zuwanderungsgesetz in Germany connotes that migrants are not automatically seen as immigrants.

I6 The Gulf States are an interesting case, which we can not cover here in detail. Some of these 'pensioner states', which obtain a substantial income from their energy resources, exclude their population from political participation on the basis of providing for them. Associated with this are significant 'modernisation deficits' resulting in an insufficient workforce, at least with regard to the necessary skills for developing an infrastructure. This workforce is increasingly made up of migrants from neighbouring countries (Egyptians, Jordanians, Palestinians, etc.) and since the I990 from Asia, who are vice versa prepared to do such work under considerable constraints to their private lives in view of the employment opportunities and wages in their home countries.

I7 Moreover, this also expresses the Europeanisation of research, as efforts in the English context, promoted by the Labour government, are at the same time linked to projects funded by the EU. 
I8 In such general terms, this point also denotes a commonplace in the sociological theory of differentiation since Marx and Durkheim.

I9 This is the reason why it can complain without any risk that its advice is ignored, as it has neither to bring about the necessary decisions nor to take responsibility for them.

20 If one accepts Treibel's definition of the problem constellation, migration research would also urgently require engagement with social theory - this might indeed not be harmful, but would increase the problem of poaching in too many reserves.

2I For a historical approach concerning the relation between disciplines and interdisciplinarity, see Swoboda (I979).

22 Durkheim (1977); it is easy to recognise that sociology tried from the outset to distance itself from a Marxian perspective, which shares with it the assumption that the cohesion of a society can only be conceived of in a 'classless society', in which asymmetries, unintended inequalities and, hence, integration problems are absent.

23 Discernible, for instance, with regard to similar education and career, shared literature, intensity of communication and mutual references in publications, shared standards, conferences, etc.

24 It is striking that migration research in different countries maintains its way of looking at problems by tying itself to politically mediated patterns of conceptualising, in significant isolation from the general and special theoretical debate in related disciplines - it operates only in a limited way with an internal orientation. In Germanspeaking sociology, this can be seen in the fact that the debate about adequate theoretical concepts for the description and explanation of inequality, conducted for more than twenty years in inequality research, and the question of the relation between inequality research and differentiation theory in migration research were kept at a distance - as if migrants were clear cut cases (of inequality), for which these debates are of no significance. This has only started to change in recent years: Bommes (2003a), Weiß (2005) and the latest Sinus study (Sinus Sociovision 2008) demonstrate that this point of view has no reason apart from an established division of labour between nationally oriented inequality research interested in the position of citizens in the social structure and migration research covering the 'rest'.

25 In difference to the functional orientation of fundamental research understood as the orientation towards securing the conditions to experience the world in the same manner.

26 Regardless of the fact that the usability of knowledge is decided by its users and not its producers (Wingens and Fuchs 1989).

27 In the Netherlands, there was a strong denunciation of researchers who were accused of having invented multicultural illusions. The public debate which emerged during 2006/07 in German daily and weekly newspapers about the achievements and failures of migration research, about right and wrong science (cf. Bommes 2006), threw glaring light on the awkward situation of migration research, according to Kuhn (1970). He argues that solutions are only seen as sufficient when they are accepted by many. They 'may not, however, be drawn at random from society as a whole', but they have to come from the scientific community. 'One of the strongest, if still unwritten, rules of scientific life is the prohibition of appeals to heads of state or to the populace at large in matters scientific' (I68).

28 Outside descriptions are not only produced in science: The economy describes politics, education or the law under its premises and so forth. Every time the respective system is seen with its benefits for the describing system in view, whether, for instance, the educational system produces qualified individuals for the economy, families render children educable, science produces usable knowledge for political 
decisions, etc. Here the relation of the self-description of social systems and outside descriptions by sciences is the topic (cf. in detail Kieserling 2004).

29 The role of migration research as reflexive theory (for this term, see Luhmann and Schorr 1988) becomes apparent, once one compares it to disciplines that became responsible for dealing with modern society in the trajectory of the scientific system: political science for politics, economics for the economy, pedagogy for the educational system, theology for religion, etc. In all these cases, the same tension arises between outside and self-description, formulated as the question of the extent to which they are reflexive theories of the respective social system or scientific theories. Reflexive theories take up the differentiated perspectives and plausibilities of practice, presuppose them, and provide them with justifications: in pedagogy, economy, law, or (normative) political science. The described tension becomes apparent when the societal improbability of education, economy, law, or politics can still also become a topic; this can be checked by the fact that scientific contributions practically still match the problems of the functional systems they deal with.

30 Like the name of the EU-funded Network of Excellence 'Immigration, Integration and Social Cohesion in an Integrating Europe' (IMISCOE).

\section{References}

Alber, Jens (2000), 'Sozialstaat und Arbeitsmarkt: Produzieren kontinentaleuropäische Wohlfahrtsstaaten typische Beschäftigungsmuster? Gleichzeitig eine Abhandlung über einige Probleme komparativer statistischer Analyse', Leviathan 28 (4): pp. 535-69.

Bade, Klaus J. (2003), Migration in European History. Oxford: Blackwell.

Bade, Klaus J. \& Michael Bommes (2004), 'Einleitung: Integrationspotentiale in modernen europäischen Wohlfahrtsstaaten - der Fall Deutschland', in idem \& Rainer Münz (eds), Migrationsreport 2004. Fakten - Analysen - Perspektiven. Frankfurt am Main and New York: Campus, pp. 11-42.

Bauböck, Rainer (1994), Transnational Citizenship. Membership and Rights in International Migration. Aldershot: Edward Elgar.

Bommes, Michael (1999), Migration und nationaler Wohlfahrtsstaat. Ein differenzierungstheoretischer Entwurf. Opladen/Wiesbaden: Westdeutscher Verlag.

Bommes, Michael (2003a), 'The Shrinking Inclusive Capacity of the National Welfare State: International Migration and the Deregulation of Identity Formation', in Grete Brochmann (ed.), The Multicultural Challenge (Comparative Social Research, vol. 22). Amsterdam: JAI, pp. 43-67.

Bommes, Michael (2003b), 'Der Mythos des transnationalen Raumes. Oder: Worin besteht die Herausforderung des Transnationalismus für die Migrationsforschung?' in Migration im Spannungsfeld von Globalisierung und Nationalstaat (Leviathan Sonderband 22), Dietrich Thränhardt \& Uwe Hunger (eds). Wiesbaden: Westdeutscher Verlag, pp. 90-116.

Bommes, Michael (2006), 'Migrations- und Integrationspolitik in Deutschland zwischen institutioneller Anpassung und Abwehr', in idem \& Werner Schiffauer (eds), Migrationsreport 2006. Fakten - Analysen - Perspektiven. Frankfurt am Main and New York: Campus, pp. 9-30.

Bommes, Michael \& Ewa Morawska (eds) (2005), International Migration Research: Constructions, Omissions, and the Promises of Interdisciplinarity. Aldershot: Ashgate.

Boswell, Christina (2009), The Political Uses of Expert Knowledge: Immigration Policy and Social Research. Cambridge: Cambridge University Press.

Brettell, Caroline \& James Hollifield (2000), Migration Theory: Talking about Disciplines. New York: Routledge. 
Brubaker, Rogers (1992), Citizenship and Nationhood in France and Germany. Cambridge, MA: Harvard University Press.

Brubaker, Rogers (2001), 'The Return of Assimilation? Changing Perspectives on Immigration and its Sequels in France, Germany, and the United States', Ethnic and Racial Studies 24 (4): pp. 531-548.

Castles, Stephen \& Mark J. Miller (2009), The Age of Migration. International Population Movements in the Modern World, $4^{\text {th }}$ ed. Basingstoke: Palgrave Macmillan.

Cornelius, Wayne et al. (ed.) (2009), Mexican Migration and the U.S. Economic Crisis: A Transnational Perspective. Boulder, CA: Lynne Rienner.

Durkheim, Emile (1977), Über die Teilung der sozialen Arbeit. Frankfurt am Main: Suhrkamp.

Elias, Norbert (1956), 'Problems of Involvement and Detachment', British Journal of Sociology 7: pp. 226-252.

Esping-Andersen, Gøsta (1990), The Three Worlds of Welfare Capitalism. Cambridge: Polity Press.

Esping-Andersen, Gøsta (1996), Welfare States in Transition. National Adaptations in Global Economies. London: Sage.

Esping-Andersen, Gøsta (2002), Why We Need a Welfare State. Oxford: Oxford University Press.

Favell, Adrian (2001), Philosophies of Integration: Immigration and the Idea of Citizenship in France and Britain. $2^{\text {nd }}$ ed. Basingstoke: Palgrave.

Favell, Adrian (2005), 'Integration Nations: The Nation-State and Research on Immigrants in Western Europe', in Bommes, Michael \& Ewa Morawska (eds). Aldershot: Ashgate, pp. 41-86.

Ferrera, Maurizio (1998), "The Four "Social Europes": Between Universalism and Selectivity', in Martin Rhodes \& Yves Meny (eds), The Future of European Welfare: A New Social Contract? London/New York: Macmillan, St. Martin's Press, pp. 79-96.

Fligstein, Neil (2000), 'Verursacht Globalisierung die Krise des Wohlfahrtsstaates?' Berliner Journal für Soziologie 10 (3): pp. 349-379.

Freeman, Gary (2005), 'Political Science and Comparative Immigration Politics', in Bommes, Michael \& Ewa Morawska (eds). Aldershot: Ashgate, pp. 111-128.

Ganßmann, Heiner \& Michael Haas (1999), Arbeitsmärkte im Vergleich. Rigidität und Flexibilität auf den Arbeitsmärkten der USA, Japans und der BRD. Marburg: Schüren.

Goodin, Robert E. et al. (1999), The Real Worlds of Welfare Capitalism. Cambridge: Cambridge University Press.

Gosewinkel, Dieter (2003), Einbürgern und Ausschließen: die Nationalisierung der Staatsangehörigkeit vom Deutschen Bund bis zur Bundesrepublik Deutschland. Göttingen: Vandenhoeck \& Ruprecht.

Groh, Dieter, and Peter Brandt (1992), »Vaterlandslose Gesellen«. Sozialdemokratie und Nation 1860-1990. Munich: C.H. Beck.

Habermas, Jürgen (1981), Theorie des kommunikativen Handelns, 2 vols. Frankfurt am Main: Suhrkamp.

Hagedorn, Heike (2001), Wer darf Mitglied werden? Einbürgerung in Deutschland und Frankreich im Vergleich. Opladen: Leske \& Budrich.

Halfmann, Jost (2005), 'World Society and Migrations. Challenges to Theoretical Concepts of Political Sociology', in Bommes, Michael \& Ewa Morawska (eds). Aldershot: Ashgate, pp. 129-153.

Hollifield, James F. (1996), 'The Migration Crisis in Western Europe: The Search for a National Model', in Klaus J. Bade (ed.), Migration - Ethnizität - Konflikt. Systemfragen und Fallstudien. Osnabrück: Universitätsverlag Rasch, pp. 367-402.

Jacobson, David (1996), Rights Across Borders: Immigration and the Decline of Citizenship. Baltimore and London: Johns Hopkins University Press. 
Kaufmann, Franz-Xaver (2003), Sozialpolitik und Sozialstaat: Soziologische Analysen. Opladen: Leske \& Budrich.

Kaufmann, Franz-Xaver (2004), Varianten des Wohlfahtsstaats. Der deutsche Sozialstaat im internationalen Vergleich. Frankfurt am Main: Suhrkamp.

Kieserling, André (2004), 'Überschätzte Reflexionstheorien. Die politische Theorie im Vergleich', in idem, Selbstbeschreibung und Fremdbeschreibung. Beiträge zur Soziologie soziologischen Wissens. Frankfurt am Main: Suhrkamp, pp. 170-191.

Koselleck, Reinhart (1992), 'Volk, Nation. Einleitung', in Otto Brunner, Werner Conze \& Reinhart Koselleck (eds), Geschichtliche Grundbegriffe. Historisches Lexikon zur politisch-sozialen Sprache in Deutschland, vol. 7. Stuttgart: Klett-Cotta, pp. 142-149.

Kuhn, Thomas S. (1970), The Structure of Scientific Revolutions (International Encyclopedia of Unified Science, vol. 2.2): University of Chicago Press; German: (1976) Die Struktur wissenschaftlicher Revolutionen, $2^{\text {nd }}$ revised ed. Frankfurt am Main: Suhrkamp.

Lavenex, Sandra (2005), 'National Frames in Migration Research: The Tacit Political Agenda', in in Bommes, Michael \& Ewa Morawska (eds). Aldershot: Ashgate, pp. 243260.

Leibfried, Stephan \& Michael Zürn (2006), Transformations of the State? Cambridge, MA: Cambridge University Press.

Luhmann, Niklas (1989), 'Individuum, Individualität, Individualismus', in idem, Gesellschaftsstruktur und Semantik. Studien zur Wissenssoziologie der modernen Gesellschaft 3. Frankfurt am Main: Suhrkamp, pp. 149-258.

Luhmann, Niklas (1990), Die Wissenschaft der Gesellschaft. Frankfurt am Main: Suhrkamp.

Luhmann, Niklas \& Karl Eberhard Schorr (1988), Reflexionsprobleme im Erziehungssystem. $2^{\text {nd }}$ ed. Frankfurt am Main: Suhrkamp.

Maas, Utz (2007), 'Sprache und Sprachen in der Migrationsgesellschaft. Die schriftkulturelle Dimension' (IMIS-Schriften 15). Göttingen: V\&R unipress.

Marshall, Thomas H. (1950), Citizenship and Social Class and other Essays. Cambridge: Cambridge University Press.

Massey, Douglas S. et al. (1998), Worlds in Motion: Understanding International Migration at the End of the Millenium. Oxford: Clarendon Press.

Meyer, Jon W. et al. (1997), 'World Society and the Nation-State', American Journal of Sociology 103: pp. 144-181.

Miles, Robert (1993), The Articulation of Racism and Nationalism: Reflections on European History. Oxford: Berg.

Miles, Robert (1994), Racism after 'Race Relations'. London: Routledge.

Obinger, Herbert, Heinz Rothgang \& Stephan Leibfried (2006), 'The State and its Welfare State - How do Welfare State Changes Affect the Make-up of the Nation State', Social Policy and Administration 40 (3): pp. 250-266.

Opielka, Michael (2004), Sozialpolitik. Grundlagen und vergleichende Perspektiven. Reinbek bei Hamburg: Rowohlt.

Schmid, Josef (2002), Wohlfahrtsstaaten im Vergleich. Soziale Sicherung in Europa: Organisation, Finanzierung, Leistungen und Probleme. Opladen: Leske \& Budrich.

Scholten, Peter (2007), Constructing Immigrant Policies. Research-policy Relations and Immigrant Integration in the Netherlands, 1970-2004. PhD thesis, University of Twente, Arnhem: Printpartners Ipskamp.

Sinus Sociovision (2008), Migranten-Milieus. Lebenswelten und Werte von Menschen mit Migrationshintergrund in Deutschland. Sozialwissenschaftliche Repräsentativuntersuchung für das Bundesministerium für Familie, Senioren, Frauen und Jugend. Heidelberg.

Soysal, Yasemin (1994), Limits of Citizenship: Migrants and Postnational Membership in Europe. Chicago and London: University of Chicago Press.

Stichweh, Rudolf (1979), 'Differenzierung der Wissenschaft', Zeitschrift für Soziologie 8 (1): pp. 82-101. 
Stichweh, Rudolf (1998), 'Migration, nationale Wohlfahrtsstaaten und die Entstehung der Weltgesellschaft', in Michael Bommes \& Jost Halfmann (eds), Migration in nationalen Wohlfahrtsstaaten. Theoretische und vergleichende Untersuchungen (IMIS-Schriften, vol. 6). Osnabrück: Universitätsverlag Rasch, pp. 49-61.

Swaan, Abram de (1988), In the Care of the State: Health Care, Education and Welfare in Europe and the USA in the Modern Era. Cambridge: Polity Press.

Swoboda, Wolfram W. (1979), 'Disciplines and Interdisciplinarity: A Historical Perspective', in Joseph J. Kockelmans (ed.), Interdisciplinarity and Higher Education. University Park: Pennsylvania State University Press, pp. 49-92.

Taylor, Charles (1993), Multikulturalismus und die Politik der Anerkennung. Frankfurt am Main: Fischer.

Tenbruck, Friedrich H. (1981), 'Emile Durkheim oder die Geburt der Gesellschaft aus dem Geist der Soziologie', Zeitschrift für Soziologie 10: pp. 333-50.

Tenbruck, Friedrich H. (1992), 'Was war der Kulturvergleich, ehe es den Kulturvergleich gab?' in Joachim Matthes (ed.), Zwischen den Kulturen? (Soziale Welt, Sonderband 8). Göttingen: Schwartz, pp. 13-35.

Thomas, William I. \& Florian Znaniecki (1958), The Polish Peasant in Europe and America $\left(1^{\text {st }}\right.$ ed. 1918), New York: Dover.

Thränhardt, Dietrich \& Uwe Hunger (2003), Migration im Spannungsfeld von Globalisierung und Nationalstaat (Leviathan Sonderheft 22). Wiesbaden: Westdeutscher Verlag.

Tilly, Charles (1990), Coercion, Capital and European States: AD 990-1990. Cambridge, MA: Blackwell.

Treibel, Annette (1988), Engagement und Distanzierung in der westdeutschen Ausländerforschung. Eine Untersuchung ihrer soziologischen Beiträge. Stuttgart: Enke.

Treibel, Annette (1990), Migration in modernen Gesellschaften. Soziale Folgen von Einwanderung und Gastarbeit. Weinheim and Munich: Juventa.

Vasta, Ellie (2006), 'Migration and Migration Research in Australia', in Vasta and Vuddalamay (eds). Basingstoke: Palgrave Macmillan, pp. 13-78.

Vasta, Ellie \& Vasoodeven Vuddalamay (eds) (2006), International Migration and the Social Sciences: Confronting National Experiences in Australia, France and Germany. Basingstoke: Palgrave Macmillan.

Walzer, Michael (1983), Spheres of Justice. A Defence of Pluralism and Equality. New York: Basic Books.

Walzer, Michael (1990), The Communitarian Critique of Liberalism. Political Theory 18: pp. 6-23.

Weiß, Anja (2005), The Transnationalization of Social Inequality. Conceptualising Social Positions on a World Scale. Current Sociology 53 (4): pp. 707-728.

Wingens, Matthias \& Stephan Fuchs (1989), 'Ist die Soziologie gesellschaftlich irrelevant?', Zeitschrift für Soziologie 18 (8): pp. 208-219. 



\section{References}

Bommes, M. (2011), Migration und Migrationsforschung in der modernen Gesellschaft. IMIS-Beiträge 38. University of Osnabrück.

Bommes, M. (2008a), “'Integration findet vor Ort statt”: Über die Neugestaltung kommunaler Integrationspolitik', in Migrationsreport 2008: Fakten - Analysen - Perspektiven; für den Rat für Migration herausgegeben von Michael Bommes und Marianne Krüger-Potratz, 159-194. Frankfurt am Main/New York: Campus.

Bommes, M. (2008b), 'Welfare systems and migrant minorities: The cultural dimension of social policies and its discriminatory potential', in Europarat (ed.), Reconciling migrants' well-being and the common interest: Economy, welfare state and citizenship in transition (Trends in social cohesion no. 19), 129-158. Straßburg: Council of Europe.

Bommes, M. (2006), 'Illegale Migration in der modernen Gesellschaft: Resultat und Problem der Migrationspolitik europäischer Nationalstaaten', in M. Bommes \& J. Alt (eds), Illegalität: Grenzen und Möglichkeiten der Migrationspolitik, 95-116. Wiesbaden: VSVerlag.

Bommes, M. (2005), 'Transnationalism or assimilation?', in SOWI-ONLINE.DE at www. sowi-online.de/reader/journal/2005-1/transnationalism_assimilation_bommes.htm.

Bommes, M. (2004), 'Zur Bildung von Verteilungsordnungen in der funktional differenzierten Gesellschaft. Erläutert am Beispiel "ethnischer Ungleichheit” von Arbeitsmigranten', in T. Schwinn (ed.), Differenzierung und soziale Ungleichheit: Die zwei Soziologien und ihre Verknüpfung, 399-428. Frankfurt am Main: Humanities Online.

Bommes, M. (2003), 'Migration in der modernen Gesellschaft', Geographische Revue 5 (2): 41-58.

Bommes, M. (2000), 'National welfare state, biography and migration: Labour migrants, ethnic Germans and the re-ascription of welfare state membership', in M. Bommes \& A. Geddes (eds), Welfare and immigration: Challenging the borders of the welfare state, 90108. London: Routledge.

Bommes, M. \& V. Tacke (2006), 'Das Allgemeine und das Besondere des Netzwerkes', in B. Hollstein \& F. Straus (eds), Qualitative Netzwerkanalyse: Konzepte, Methoden, Anwendungen, 37-62. Wiesbaden: VS-Verlag.

Bommes, M. \& D. Thränhardt (2010), 'Introduction: National paradigms of migration research', in M. Bommes \& D. Thränhardt (eds), National paradigms of migration research (IMIS-Schriften 13), 9-38. Göttingen: V\&R unipress. 

Other IMISCOE titles

\section{IMISCOE Research}

Rinus Penninx, Maria Berger, Karen Kraal, Eds.

The Dynamics of International Migration and Settlement in Europe: A State of the Art 2006 (ISBN 978905356866 8)

(originally appearing in IMISCOE Joint Studies)

Leo Lucassen, David Feldman, Jochen Oltmer, Eds.

Paths of Integration: Migrants in Western Europe (1880-2004)

2006 (ISBN 978905356883 5)

Rainer Bauböck, Eva Ersbøll, Kees Groenendijk, Harald Waldrauch, Eds. Acquisition and Loss of Nationality: Policies and Trends in 15 European Countries, Volume 1: Comparative Analyses

2006 (ISBN 978905356920 7)

Rainer Bauböck, Eva Ersbøll, Kees Groenendijk, Harald Waldrauch, Eds. Acquisition and Loss of Nationality: Policies and Trends in 15 European Countries, Volume 2: Country Analyses

2006 (ISBN 978905356921 4)

Rainer Bauböck, Bernhard Perchinig, Wiebke Sievers, Eds.

Citizenship Policies in the New Europe

2007 (ISBN 978905356922 1)

Veit Bader

Secularism or Democracy? Associational Governance of Religious

Diversity

2007 (ISBN 978905356999 3)

Holger Kolb, Henrik Egbert, Eds.

Migrants and Markets: Perspectives from Economics and the Other

Social Sciences

2008 (ISNB 978905356684 8)

Ralph Grillo, Ed.

The Family in Question: Immigrant and Ethnic Minorities in

Multicultural Europe

2008 (ISBN 978905356869 9) 
Corrado Bonifazi, Marek Okólski, Jeannette Schoorl, Patrick Simon, Eds. International Migration in Europe: New Trends and New Methods of Analysis

2008 (ISBN 978905356894 1)

Maurice Crul, Liesbeth Heering, Eds.

The Position of the Turkish and Moroccan Second Generation in Amsterdam and Rotterdam: The TIES Study in the Netherlands 2008 (ISBN 978908964061 1)

Marlou Schrover, Joanne van der Leun, Leo Lucassen, Chris Quispel, Eds. Illegal Migration and Gender in a Global and Historical Perspective 2008 (ISBN 978908964047 5)

Gianluca P. Parolin

Citizenship in the Arab World: Kin, Religion and Nation-State 2009 (ISBN 978908964045 1)

Rainer Bauböck, Bernhard Perchinig, Wiebke Sievers, Eds.

Citizenship Policies in the New Europe: Expanded and Updated Edition 2009 (ISBN 978908964108 3)

Cédric Audebert, Mohamed Kamel Doraï, Eds.

Migration in a Globalised World: New Research Issues and Prospects 2010 (ISBN 978908964 1571)

Richard Black, Godfried Engbersen, Marek Okólski, Cristina Pantîru, Eds. A Continent Moving West? EU Enlargement and Labour Migration from Central and Eastern Europe 2010 (ISBN 978908964156 4)

Charles Westin, José Bastos, Janine Dahinden, Pedro Góis, Eds. Identity Processes and Dynamics in Multi-Ethnic Europe 2010 (ISBN 978908964046 8)

Rainer Bauböck, Thomas Faist, Eds.

Diaspora and Transnationalism: Concepts, Theories and Methods 2010 (ISBN 978908964238 7)

Liza Mügge

Beyond Dutch Borders: Transnational Politics among Colonial Migrants, Guest Workers and the Second Generation 2010 (ISBN 978908964244 8) 
Peter Scholten

Framing Immigrant Integration: Dutch Research-Policy Dialogues in Comparative Perspective

2011 (ISBN 978908964284 4)

Albert Kraler, Eleonore Kofman, Martin Kohli, Camille Schmoll, Eds. Gender, Generations and the Family in International Migration

2011 (ISBN 978908964285 1)

Michael Bommes, Giuseppe Sciortino, Eds.

Foggy Social Structures: Irregular Migration, European Labour Markets and the Welfare State

2011 (ISBN 978908964341 4)

Giovanna Zincone, Rinus Penninx, Maren Borkert, Eds.

Migration Policymaking in Europe: The Dynamics of Actors and Contexts in Past and Present

2011 (ISBN 978908964370 4)

Blanca Garcés-Mascareñas

State Regulation of Labour Migration in Malaysia and Spain: Markets, Citizenship and Rights

2012 (ISBN 978908964286 8)

Julie Vullnetari

Albania on the Move: Links between Internal and International Migration 2012 (ISBN 978908964355 1)

Bram Lancee

Immigrant Performance in the Labour Market: Bonding and Bridging Social Capital

2012 (ISBN 978908964357 5)

Maurice Crul, Jens Schneider, Frans Lelie, Eds.

The European Second Generation Compared: Does the Integration Context Matter?

2012 (ISBN 978908964443 5)

Christina Boswell, Gianni D’Amato, Eds.

Immigration and Social Systems: Collected Essays of Michael Bommes

2012 (ISBN 978908964453 4) 
Ulbe Bosma, Ed.

Post-Colonial Immigrants and Identity Formations in the Netherlands 2012 (ISBN 978908964454 1)

Marek Okólski, Ed.

European Immigrations: Trends, Structures and Policy Implications

2012 (ISBN 978908964457 2)

\section{IMISCOE Reports}

Rainer Bauböck, Ed.

Migration and Citizenship: Legal Status, Rights and Political Participation 2006 (ISBN 978905356888 0)

Michael Jandl, Ed.

Innovative Concepts for Alternative Migration Policies: Ten Innovative Approaches to the Challenges of Migration in the 21st Century 2007 (ISBN 978905356990 0)

Jeroen Doomernik, Michael Jandl, Eds.

Modes of Migration Regulation and Control in Europe

2008 (ISBN 978905356689 3)

Michael Jandl, Christina Hollomey, Sandra Gendera, Anna Stepien, Veronika Bilger

Migration and Irregular Work In Austria: A Case Study of the Structure and Dynamics of Irregular Foreign Employment in Europe at the

Beginning of the $21^{\text {st }}$ Century

2008 (ISBN 978908964053 6)

Heinz Fassmann, Ursula Reeger, Wiebke Sievers, Eds.

Statistics and Reality: Concepts and Measurements of Migration in Europe 2009 (ISBN 978908964052 9)

Karen Kraal, Judith Roosblad, John Wrench, Eds.

Equal Opportunities and Ethnic Inequality in European Labour Markets:

Discrimination, Gender and Policies of Diversity

2009 (ISBN 978908964126 7)

Tiziana Caponio, Maren Borkert, Eds.

The Local Dimension of Migration Policymaking 2010 (ISBN 978908964232 5) 
Raivo Vetik, Jelena Helemäe, Eds.

The Russian Second Generation in Tallinn and Kohtla-Järve: The TIES Study in Estonia

2010 (ISBN 978908964250 9)

\section{IMISCOE Dissertations}

Panos Arion Hatziprokopiou

Globalisation, Migration and Socio-Economic Change in Contemporary Greece: Processes of Social Incorporation of Balkan Immigrants in Thessaloniki

2006 (ISBN 978905356873 6)

Floris Vermeulen

The Immigrant Organising Process: Turkish Organisations in Amsterdam and Berlin and Surinamese Organisations in Amsterdam, 1960-2000 2006 (ISBN 978905356875 0)

Anastasia Christou

Narratives of Place, Culture and Identity: Second-Generation

Greek-Americans Return 'Home'

2006 (ISBN 978905356878 1)

Katja Rušinović

Dynamic Entrepreneurship: First and Second-Generation Immigrant

Entrepreneurs in Dutch Cities

2006 (ISBN 978905356972 6)

Ilse van Liempt

Navigating Borders: Inside Perspectives on the Process of Human

Smuggling into the Netherlands

2007 (ISBN 978905356930 6)

Myriam Cherti

Paradoxes of Social Capital: A Multi-Generational Study of Moroccans in London

2008 (ISBN 978905356032 7)

Marc Helbling

Practising Citizenship and Heterogeneous Nationhood: Naturalisations in Swiss Municipalities

2008 (ISBN 978908964034 5) 
Jérôme Jamin

L'imaginaire du complot: Discours d'extrême droite en France et aux Etats-Unis

2009 (ISBN 978908964048 2)

Inge Van Nieuwenhuyze

Getting by in Europe's Urban Labour Markets: Senegambian Migrants'

Strategies for Survival, Documentation and Mobility

2009 (ISBN 978908964050 5)

Nayla Moukarbel

Sri Lankan Housemaids in Lebanon: A Case of 'Symbolic Violence' and 'Every Day Forms of Resistance'

2009 (ISBN 978908964051 2)

John Davies

'My Name Is Not Natasha': How Albanian Women in France Use

Trafficking to Overcome Social Exclusion (1998-2001)

2009 (ISBN 978905356707 4)

Dennis Broeders

Breaking Down Anonymity: Digital Surveillance of Irregular Migrants in Germany and the Netherlands

2009 (ISBN 978908964159 5)

Arjen Leerkes

Illegal Residence and Public Safety in the Netherlands

2009 (ISBN 978908964049 9)

Jennifer Leigh McGarrigle

Understanding Processes of Ethnic Concentration and Dispersal:

South Asian Residential Preferences in Glasgow

2009 (ISBN 9789053566718 )

João Sardinha

Immigrant Associations, Integration and Identity: Angolan, Brazilian

and Eastern European Communities in Portugal

2009 (ISBN 978908964036 9)

Elaine Bauer

The Creolisation of London Kinship: Mixed African-Caribbean and White British Extended Families, 1950-2003

2010 (ISBN 978908964235 6) 
Nahikari Irastorza

Born Entrepreneurs? Immigrant Self-Employment in Spain 2010 (ISBN 978908964243 1)

Marta Kindler

A Risky Business? Ukrainian Migrant Women in Warsaw's Domestic Work Sector

2011 (ISBN 978908964 3278)

IMISCOE Textbooks

Marco Martiniello, Jan Rath, Eds.

Selected Studies in International Migration and Immigrant Incorporation 2010 (ISBN 978908964 1601) 
Michael Bommes was one of the most brilliant and original migration studies scholars of our time. This posthumous collection brings together a selection of his most important work on immigration and the welfare state, immigrant integration, discrimination, irregular migration, migrant networks and migration policy research.

Christina Boswell is Professor of Politics at the School of Social and Political Science at the University of Edinburgh. Gianni D'Amato is Professor of Migration and Citizenship studies at the University of Neuchâtel and Director of the Swiss Forum of Migration and Population Studies (SFM).

"This collection demonstrates the insight and rigour of Bommes' fundamental contributions to immigration studies. It provides sharp, essential observations of social and political responses to immigration - to be read by anyone interested in these issues."

Andrew Geddes, Professor of Politics, University of Sheffield

"In Bommes, the academy lost a scholar with penetrating analyses of migration, the welfare state and social systems where the two interact. By completing his last project, Boswell and D'Amato have done scholarship a lasting service. A major contribution to public debate and a tribute to a very great man."

Randall Hansen, Canada Research Chair in Immigration \& Governance, University of Toronto

"Michael Bommes was undoubtedly the most theoretically inspiring migration scholar working in German. This excellent collection makes some of his best work accessible to a broader English-speaking audience."

Christian Joppke, Chair in General Sociology, University of Bern

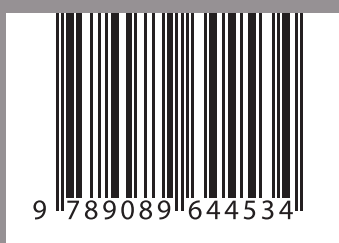

